\title{
SPATIAL DISTRIBUTION OF SELENIUM AND OTHER INORGANIC CONSTITUENTS IN GROUND WATER UNDERLYING A DRAINED AGRICULTURAL FIELD, WESTERN SAN JOAQUIN VALLEY, CALIFORNIA
}

By David A. Leighton, S.J. Deverel, and Janet K. Macdonald

U.S. GEOLOGICAL SURVEY

Water-Resources Investigations Report 91-4119

REGIONAL AQUIFER-SYSTEM ANALYSIS

Prepared in cooperation with the

SAN JOAQUIN VALLEY DRAINAGE PROGRAM

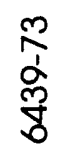




\section{U.S. DEPARTMENT OF THE INTERIOR \\ MANUEL LUJAN, JR., Secretary}

U.S. GEOLOGICAL SURVEY

Dallas L. Peck, Director

Any use of trade, product, or firm names in this publication is for descriptive purposes only and does not imply endorsement by the U.S. Government.

For sale by the Books and Open-File Reports Section, U.S. Geological Survey Federal Center, Box 25425

Denver, CO 80225

For additional information write to:

District Chief

U.S. Geological Survey

Federal Building, Room W-2233

2800 Cottage Way

Sacramento, CA 95825 


\section{CONTENTS}

\section{Abstract 1}

Introduction 1

Previous investigations 2

Description of area and agricultural field 2

Study design $\mathbf{3}$

Well design and construction 3

Sample collection 6

Field methods 7

Laboratory methods 7

Water samples 7

Samples of aquifer solids 7

Data presentation and interpretation 8

Spatial distribution of chemical constituents and isotopes in ground water $\mathbf{8}$

Selenium, salinity, and isotopes $\mathbf{8}$

Major ions 14

Other trace elements 14

Temporal variability of constituents in ground water and drainwater 15

Ground water 15

Drainwater 16

Ground-water-flow patterns 20

Physical factors affecting ground-water flow $\mathbf{2 2}$

Texture 26

Hydraulic conductivity 26

Distribution of chemical constituents in the solid phase

Summary and conclusions $\mathbf{3 2}$

References cited 33

\section{FIGURES}

1. Map showing location of the drained agricultural field 4

2,3. Schematics showing:

2. Drainage system for the drained agricultural field and location of cluster sites and geohydrologic sections $A-A^{\prime}$ and $B-B^{\prime} \quad 5$

3. Distribution of selenium concentrations in ground water 9

4-6. Graphs showing:

4. Depth distribution of selenium concentrations in ground water $\mathbf{1 0}$

5. Relation of $\log _{10}$ selenium concentrations and $\log _{10}$ dissolved-solids concentrations for ground-water samples $\mathbf{1 0}$

6. Relation of delta deuterium to delta oxygen-18 for ground-water samples $\mathbf{1 1}$

7. Schematic showing distribution of tritium concentrations in ground water 13

8. Graph showing depth distribution of tritium concentrations in ground water 14

9. Trilinear diagram showing relation of major-ion chemistry to ground-water salinity 
10-13. Graphs showing:

10. Depth distribution of gypsum saturation indexes 17

11. Depth distribution of selected trace elements 18

12. Selenium and dissolved-solids concentrations and delta oxygen-18 ratio measured over time for the drain sump 20

13. Changes in hydraulic head for wells at sites 7 and $14 \quad 21$

14,15 . Geohydrologic sections showing distribution of hydraulic head and generalized directions of ground-water flow superimposed on existing sand layers during periods of high and low hydraulic head:

14. Along geohydrologic section $A-A^{\prime} \quad 23$

15. Along geohydrologic section $B-B^{\prime} \quad 24$

16. Schematic showing areal distribution of hydraulic head 3 meters below land surface and generalized direction of ground-water flow $\mathbf{2 5}$

17. Geohydrologic sections showing texture distribution along geohydrologic sections $A-A^{\prime}$ and $B-B^{\prime} \quad 27$

18-20. Graphs showing:

18. Relation of hydraulic conductivity determined by the methods of Hvorslev (1951) and Cooper and others (1967) in wells with screened intervals opposite coarse- and fine-grained deposits 29

19. Concentrations of total, soluble, and residual selenium and organic carbon in the solid phase 31

20. Relation of percentage of organic carbon to residual selenium concentrations $\mathbf{3 2}$

\section{TABLES}

1. Principal component scores for the solid phase chemical data $\mathbf{3 0}$

2. Site, well depth, and constituents determined for water samples collected in the drained agricultural field $\mathbf{3 5}$

3. Field measurements and chemical analysis for major ions, dissolved organic carbon, stable isotopes of hydrogen and oxygen, and tritium $\mathbf{4 0}$

4. Chemical analysis of dissolved trace elements $\mathbf{4 8}$

5. Chemical analysis of drilling-core samples $\mathbf{5 2}$

6. Selenium, dissolved solids, and stable isotope data for wells with multiple samples $\mathbf{6 8}$

7. Field measurements and chemical analysis of drainwater $\mathbf{7 1}$

\section{Conversion Factors}

\begin{tabular}{rll}
\hline Multiply & By & To obtain \\
\hline centimeter $(\mathrm{cm})$ & 0.3937 & inch \\
hectare (ha) & 2.471 & acre \\
kilometer $(\mathrm{km})$ & 0.6214 & mile \\
meter $(\mathrm{m})$ & 3.281 & foot \\
meter per annum $(\mathrm{m} / \mathrm{a})$ & 3.281 & foot per year \\
millimeter $(\mathrm{mm})$ & 0.03937 & inch \\
\hline
\end{tabular}
equation:

Temperature is given in degrees Celsius $\left({ }^{\circ} \mathrm{C}\right)$, which can be converted to degrees Fahrenheit $\left({ }^{\circ} \mathrm{F}\right)$ by the following

$$
{ }^{\circ} \mathrm{F}=1.8\left({ }^{\circ} \mathrm{C}\right)+32 \text {. }
$$




\title{
SPATIAL DISTRIBUTION OF SELENIUM AND OTHER
}

\section{INORGANIC CONSTITUENTS IN GROUND WATER UNDERLYING A DRAINED AGRICULTURAL FIELD, WESTERN SAN JOAQUIN VALLEY, CALIFORNIA}

\author{
By David A. Leighton, S.J. Deverel, and Janet K. Macdonald
}

\begin{abstract}
This report presents the results of a study of the geochemical and hydrologic factors affecting the distribution of selenium and other inorganic constituents in the shallow ground water underlying an artificially drained agricultural field. Ground-water samples collected from observation wells located throughout the field show the highest salinity and selenium concentrations at a depth of 6 to 9 meters. Oxygen- and hydrogen-stable isotope data indicate that this highly saline, selenium-rich ground water was once subject to evapoconcentration near land surface. Subsequent application of less saline irrigation water has displaced this saline, selenium-rich water downward. The distribution of tritium in ground-water samples collected from different depths supports this hypothesis.
\end{abstract}

During the irrigation season, ground-water flow is primarily downward; during fallow periods, flow is upward. Subsurface sand layers and a regional collector line affect the horizontal flow of ground water. Except during and immediately after irrigation, the drain laterals do not substantially influence flow.

Principal-component analysis of the chemical associations in the solid phase indicates that most of the variation in the chemical composition is accounted for by a felsic component. The elements associated with this component are those associated with alumino silicate and iron and manganese oxides. Soluble selenium represents a small fraction of the total concentration of selenium in the unsaturated and shallow saturated zones. Most of the soluble selenium has been leached from these zones by irrigation. The concentrations of selenium in the solid phase that were not in a soluble form were highest in the unsaturated zone and were significantly correlated with percentage of organic carbon, indicating that a large fraction of the solid phase selenium was associated with organic matter.

\section{INTRODUCTION}

High concentrations of selenium in subsurface agricultural drainwater in the western San Joaquin Valley, California, have caused high mortality rates in waterfowl at Kesterson National Wildlife Refuge near Gustine, California (Ohlendorf and others, 1986). Agricultural drainage systems were installed in some low-lying areas of the western San Joaquin Valley to prevent accumulation of soil root-zone salt that adversely affects crop production. These systems generally maintain the water table below about $1.5 \mathrm{~m}$ because evaporation of shallow ground water from a water table within $1.5 \mathrm{~m}$ of land surface can lead to accumulation of salts in the unsaturated zone and an increase in ground-water salinity. Shallow ground water affects about 100,000 ha of agricultural land in the western San Joaquin Valley (U.S. Bureau of Reclamation, 1984). High concentrations of boron, molybdenum, and arsenic in drainwater and ground water are also of primary environmental concern because of documented or possible adverse effects on water quality, public health, agricultural productivity, and fish and wildlife (San Joaquin Valley Drainage Program, 1990).

The salinity and the concentrations of selenium and other inorganic constituents in the soils and shallow ground water are related to the deposition, geomorphology, and hydrology of the alluvial fans (Deverel and Millard, 1988; Deverel and Gallanthine, 1989). Leaching of naturally occurring salts and associated trace inorganic constituents from soils by irrigation water is the primary factor resulting in the spatially variable concentrations of trace inorganic constituents and dissolved salts in shallow ground 
water. Evapotranspiration of shallow ground water in the low-lying areas of the western San Joaquin Valley has led to the accumulation of salts in ground water and soils (Deverel and Gallanthine, 1989). Agricultural drainage systems in some low-lying areas collect this saline ground water. An understanding of the geochemical and hydrologic processes affecting the chemical composition of ground water associated with agricultural drainage systems is required for the development of effective water-management strategies.

This report describes the results of a study of the spatial distribution of selected chemical constituents in shallow ground water (within $15 \mathrm{~m}$ of land surface) underlying an artificially drained agricultural field in the western San Joaquin Valley, California. The objectives of this study were: (1) to assess the spatial distribution and temporal variability of salinity, selenium, organic carbon, and other inorganic constituents in ground water and aquifer solids underlying the agricultural field; (2) to identify the geochemical and hydrologic processes that affect the spatial distribution and temporal variability; and (3) to measure the physical properties of the shallow aquifer that will lead to a quantitative assessment of ground-water flow. The approach was to determine the chemical and isotopic composition of ground-water samples collected at depths ranging from 3 to $15 \mathrm{~m}$ below land surface in a single agricultural field. The chemical and isotopic composition of the ground water samples was assessed relative to ground-water-flow patterns, the irrigation and drainage history of the field, the chemical composition of the soils and aquifer materials and the temporal variability of the chemical composition of the ground water and drainwater.

This study is part of a comprehensive investigation of the hydrology and geochemistry of the western San Joaquin Valley by the U.S. Geological Survey. The studies are being done in cooperation with San Joaquin Valley Drainage Program and as part of the Regional Aquifer System Analysis Program of the U.S. Geological Survey.

\section{PREVIOUS INVESTIGATIONS}

There are few other investigations of the spatial distribution of chemical constituents in shallow ground water associated with agricultural drainage systems. Deverel and Fujii (1988) evaluated the processes affecting the chemistry of shallow ground water associated with agricultural drainage systems in three fields in the northern part of the Panoche Creek alluvial fan. The highest salinity and selenium concentrations in shallow ground-water samples were associated with isotopic enrichment, and therefore, a result of evapotranspiration from a shallow water table (Deverel and Fujii, 1988). Varying degrees of displacement of this saline, high selenium water toward the drain laterals resulted in different distributions of salinity, selenium, and isotopes measured in the three fields.

Transport of saline ground water in artificially drained agricultural fields in the western San Joaquin Valley has been examined by Pillsbury and others (1965) and Jury (1975a, 1975b). These authors generally agreed that several decades would be required for saline ground water to travel to drain laterals from midway between the laterals, which are typically 50 to $100 \mathrm{~m}$ apart. Luthin and others (1969), Ortiz and Luthin (1970), Raats (1978), Mansell and others (1985), and other authors have evaluated conservative solute movement in ground water associated with artificially drained agricultural fields. Although the results presented by these authors are not specifically applicable to the San Joaquin Valley problem, their analyses generally agree with the Jury (1975a, 1975b) approach.

\section{DESCRIPTION OF AREA AND AGRICULTURAL FIELD}

California's San Joaquin Valley is a structural trough between the Sierra Nevada on the east and the folded and faulted Coast Ranges on the west. The Sierra Nevada, a fault block that dips southeastward, is composed of igneous and metamorphic rock, mostly of pre-Tertiary age. The Diablo Range of the California Coast Ranges, which borders the study area to the west, consists of an exposed Upper Jurassic and Cretaceous core assemblage of marine origin overlain and juxtaposed with Cretaceous marine and Tertiary marine and continental deposits. The alluvial-fan deposits of the western valley are derived exclusively from Diablo Range rocks (Miller and others, 1971). The basin deposits are derived from the Sierra Nevada and the Diablo Range, but are dominated by Sierra Nevada deposits.

The deposition of the alluvial fans on the westernmost edge of the valley has been described by Bull (1964). At the margins of the alluvial fans, soils are fine grained and often saline (Harradine, 1950). Ground water at the margins of the alluvial fans is saline, and selenium concentrations are high (Deverel and Gallanthine, 1989). 
Ground-water flow in the western valley has changed considerably since the development of irrigated agriculture. Under natural conditions, groundwater recharge was primarily from infiltration of water from intermittent streams in the upper parts of the alluvial fans (Belitz and Heimes, 1990). Ground water flowed from southwest to northeast, reflecting the general topographic trend of the area. Discharge from the system was by evapotranspiration and streamflow along the valley trough (Mendenhall and others, 1916; Davis and Poland, 1957). Flowing wells mapped by Mendenhall and others (1916) indicate that artesian conditions prevailed along a broad stretch of the valley trough.

Development of irrigated agriculture began in the late 1800's with ground-water pumping and diversions from the San Joaquin River. Ground-water pumping became the primary source of irrigation water in the 1920's and reached a maximum in the 1950's. During agricultural development, pumping and evapotranspiration by plants became the primary discharge mechanisms. Percolation of irrigation water past crop roots became the primary recharge mechanism. The increase in recharge to the upper part of the hydrologic system and discharge from the lower part of the system resulted in a downward hydraulic gradient over most of the western valley (Belitz and Heimes, 1990).

Ground-water withdrawals until 1952 in the area north of Mendota and until 1967 in the area south of Mendota caused the water table to decline along alluvial-fan margins and in the valley trough. When surface water imported from northern California replaced ground water for irrigation, the water table rose throughout the area. The percentage of the area characterized by a water table within $6 \mathrm{~m}$ of land surface has increased substantially since 1952 (Belitz and Heimes, 1990).

The field selected for study is in an area where the water table has risen more than $12.2 \mathrm{~m}$ to within 1.8 $m$ of land surface since the early 1950's (Davis and Poland, 1957; U.S. Bureau of Reclamation, written commun., 1984) and evapotranspiration from a shallow water table has caused high ground-water salinity and selenium concentrations (Deverel and Gallanthine, 1989). Figure 1 shows the location of the drained agricultural field. The area of the field is 65 ha and cotton has always been the primary crop.

Using aerial photographs, Bull and Miller (1975) mapped the development of irrigation in the western valley. Clyde Irion (farm manager, oral commun.,
1986) stated that the field had been first irrigated sometime in the 1930's. Water initially pumped for irrigation of this field came primarily from the lower confined aquifer described by Belitz and Heimes (1990). Surface water imported from northern California through the California Aqueduct by the Federal Central Valley Project replaced pumped ground water for irrigation in the field by about 1970 .

To lower the water table, a drainage system was installed in this field in 1980. Figure 2 shows the drainage system, cluster sites, and geohydrologic sections $A-A^{\prime}$ and $B-B^{\prime}$. Drain laterals are constructed of corrugated and perforated plastic pipe buried at depths of 1.9 to $2.1 \mathrm{~m}$. Regional collectors collected drainwater from many farm-drainage systems and transported it to the San Luis Drain until 1986 (fig. 1). Since 1986, drainwater in the regional collector has been mixed with California Aqueduct water and used for irrigation.

\section{STUDY DESIGN}

To assess the spatial distribution of chemical constituents in ground water underlying the field, 202 observation wells were installed at 59 cluster sites (fig. 2). Each cluster site consisted of 1 to 5 wells drilled to depths of 3 to $15 \mathrm{~m}$ (table 2, at back of report). Samples collected from 86 of these wells were analyzed for various chemical constituents and 66 wells were used to estimate horizontal hydraulic conductivity. Ground-water samples were collected periodically from spring 1986 to summer 1988 to evaluate the spatial and temporal variability of concentrations of chemical constituents. The temporal variability of the chemical constituents was evaluated in relation to temporal changes in drain flow, hydraulic gradients in ground water, and the spatial distribution of chemical constituents. Water levels were measured periodically in all existing observation wells to characterize the shallow ground-water-flow system.

\section{WELL DESIGN AND CONSTRUCTION}

Wells at the 32 sites labeled EW, NW, and SE were completed during the summer 1985 (table 2). Two methods were used to complete these wells. At each site, $2.5-\mathrm{cm}$ diameter wells were jetted to depths of $3,4.5,6$, and $9 \mathrm{~m}$ by pumping water at high pressures through the well casing. The casing was inserted into the hole created by the high-pressure stream of water. These wells were used exclusively 


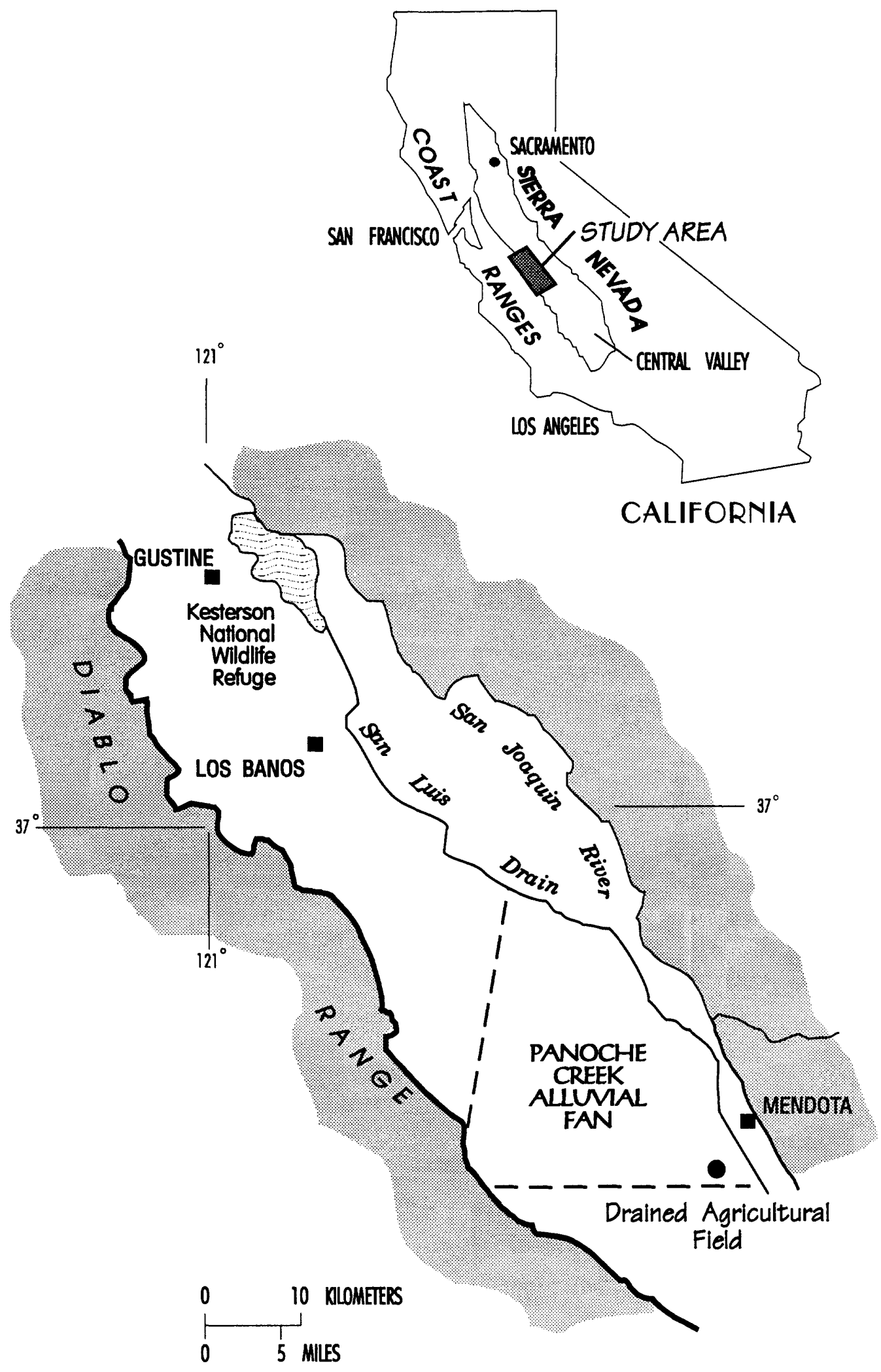

Figure 1. Location of the drained agricultural field. 


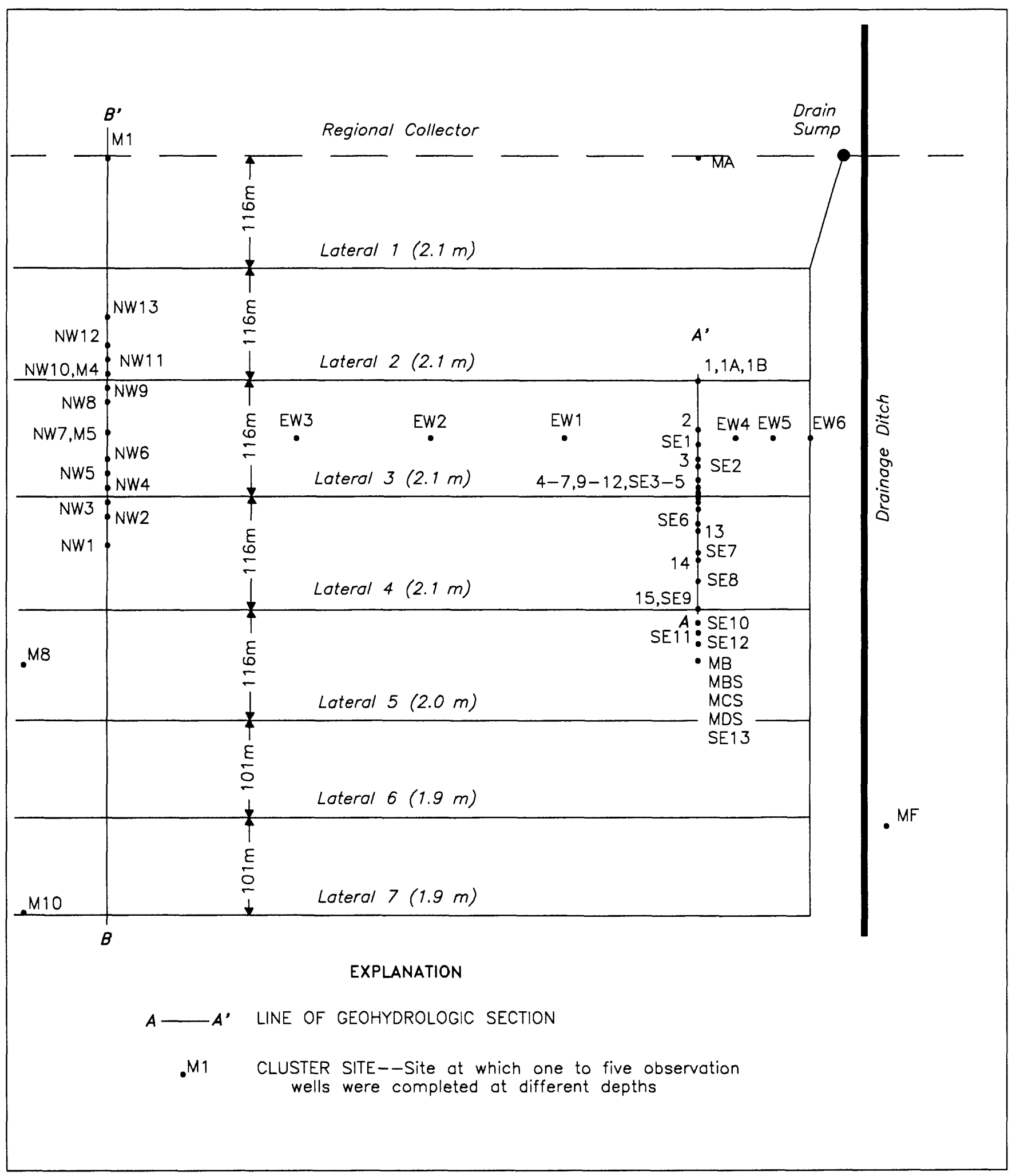

Figure 2. Drainage system for the drained agricultural field and location of cluster sites and geohydrologic sections $A-A^{\prime}$ and $B-B^{\prime}$. 
for hydraulic-head measurements. An additional well for sample collection was completed at 16 of these sites using a hand auger. The casing was set at a depth of $4 \mathrm{~m}$ with perforations over the bottom 120 $\mathrm{cm}$. Open space around the casing was back-filled with cuttings removed during the augering.

Sites labeled 1 through 15 were drilled in January and February 1986 using a hollow-stem auger. The auger was used to drill to within $1 \mathrm{~m}$ of the desired depth. To assure that the perforated section of casing was placed in a relatively undisturbed section of subsurface material, the final $1 \mathrm{~m}$ of material was removed using a core tube of the same diameter as the casing. The tube was pushed below the auger bit and the core was removed. The casing then was placed in the borehole and the augers were removed. Wells were completed at depths of $3,6,9$, and $12 \mathrm{~m}$ and the bottom $30 \mathrm{~cm}$ of the casing was screened. Each well was sealed to land surface with bentonite grout.

Wells at the $M$ sites were drilled using the hollow-stem auger in spring 1987. At these sites, the casing was screened over the bottom $60 \mathrm{~cm}$, placed in the borehole, and sand packed around the screened interval. Wells were completed at depths of $3,6,9$, 12 , and $15 \mathrm{~m}$ and all were sealed to land surface using bentonite grout. Periodically, wells were damaged or destroyed by farming operations in the field. All wells were constructed of polyvinyl chloride (PVC) pipe.

\section{SAMPLE COLLECTION}

Most of the water-quality samples were collected with tubing and positive-displacement bladder pumps constructed of Teflon and stainless steel. The submersible, $4.5-\mathrm{cm}$ stainless steel bladder pump operates by allowing water to enter through a one-way valve in the bottom of the pump. Pressurized nitrogen gas is cycled in and out of a Teflon bladder inside the pump casing, displacing the water up the Teflon tubing. Some of the observation wells were sampled using a peristaltic pump to remove water from the well through Teflon tubing and into the sample containers.

Prior to sampling, each well was pumped until the specific conductance of the water did not vary by more than 10 percent for three consecutive wellcasing volumes of water. Electrical conductivity meters were standardized with potassium chloride standards within $2,000 \mu \mathrm{S} / \mathrm{cm}$ (microsiemen per centimeter at $25^{\circ} \mathrm{C}$ ) of the well water. Temperature, specific conductance, $\mathrm{pH}$, dissolved oxygen, and oxidation reduction potential were measured several times at each well prior to sampling. Before each sample was taken, another well-casing volume was pumped.

Before collecting each sample, all sampling apparatus and containers were rinsed three times with the well water. Bicarbonate and carbonate concentrations were determined in the field for each site by incrementally titrating unfiltered samples with dilute sulfuric acid. Portable $\mathrm{pH}$ meters and electrodes were calibrated at each well and for each titration with $\mathrm{pH}$ buffers maintained at the temperature of the sample water within $\pm 2{ }^{\circ} \mathrm{C}$. Temperature was measured with mercury thermometers that were checked for accuracy against a standardized laboratory thermometer. The oxidation-reduction potential status of the sample was determined by measuring the platinum electrode redox potential. The platinum electrodes were field checked by placing in $\mathrm{pH}$ buffers saturated with Quinhydrone. These solutions have known redox potentials that can be compared to the value obtained from the meter. Dissolved-oxygen meters were calibrated by placing the probe in a chamber saturated with water vapor and adjusting the meter to the dissolved oxygen saturation value for the measured water temperature and ambient atmospheric pressure. The platinum electrode redox potential and dissolved oxygen were determined by placing the respective probes in a flow-through chamber as described by Wood (1981).

Samples for analysis of dissolved constituents were pressure filtered through $0.1-\mathrm{mm}$ membrane filters. Samples for determination of major ions and all trace elements were collected and stored in polyethylene bottles with Teflon-lined caps. All samples were acidified with nitric acid to a $\mathrm{pH}$ of less than 2 except those collected for determination of $\mathrm{pH}$, specific conductance, bicarbonate, carbonate, sulfate, chloride, silica, boron, and vanadium, which were untreated. Samples for analysis of oxygen- and hydrogen-stable isotopes and tritium were not filtered and were collected in glass bottles with polyethylene-lined caps so that there was no air space.

Drilling-core samples were collected from the deepest borehole at each site by pushing a core tube ahead of the auger bit for every $1 \mathrm{~m}$ of depth. Each core was displaced from the tube in the field and the length and a qualitative description of texture were recorded. 


\section{FIELD METHODS}

Water levels were measured monthly during the study period in all existing wells using a steel tape. Water-level recorders were installed at sites $2,7,14$, $15, \mathrm{MCS}$, and MF to provide a continuous record of water-level changes.

Hydraulic conductivities were estimated by analyzing data from single-well response tests (slug tests) in 66 wells. Fifty-four of the wells were screened in fine-grained deposits and 12 wells were screened in coarse-grained deposits. Fine-grained deposits were defined on the basis of the texture descriptions done during drilling and particle-size analysis. A known volume of water was displaced within the well, and the rate of change in the hydraulic head was measured over time with a pressure transducer connected to a data micrologger. The volume of water was displaced by lowering a length of $2.5-\mathrm{cm}$ PVC pipe filled with sand and sealed with PVC caps at both ends (the slug). The amount of head displaced in the 6- to $15-\mathrm{m}$ wells was about $30 \mathrm{~cm}$ when the slug was completely submerged. The $3-\mathrm{m}$ wells required a smaller head displacement of about $15 \mathrm{~cm}$. The water level in the wells remained above the screened interval at all times during the testing. The hydraulic characteristics of the geologic materials surrounding the screen controlled the rate at which the hydraulic head decreased.

\section{LABORATORY METHODS}

Water samples.--Major ions and trace elements were analyzed at the U.S. Geological Survey's National Water Quality Laboratory in Arvada, Colorado. Calcium, magnesium, sodium, potassium, silica, aluminum, arsenic, chromium, iron, lithium, manganese, molybdenum, and nickel were determined by atomic absorption spectrometry. Chloride and vanadium were determined by colorimetry. Boron was determined by atomic emission. Sulfate was determined by the turbidimetric procedure. All these methods are described by Fishman and Friedman (1985).

Selenium was determined by hydride generation and atomic absorption spectrometry. The method used for selenium in this study is designed to determine the total concentration of all forms of selenium present in the water sample. A sample is first subjected to an oxidative digestion to release any selenium from the organic fraction. The selenium released by this digestion, together with the inorganic selenium originally present, is then reduced to the selenite form with stannous chloride and potassium iodide mixture. The selenium hydride is generated by reducing the selenite form with sodium borohydride. The hydride gas is stripped from solution by a stream of nitrogen gas and its concentration determined by atomic absorption spectrometry.

The oxygen-isotopic composition of the water samples was determined with the carbon dioxide equilibration methods (Epstein and Mayeda, 1953). Analysis was done with a $60^{\circ}$ sector, $150-\mathrm{mm}$ radius double-collecting isotope ratio mass spectrometer. The results are reported relative to Vienna Standard Mean Ocean Water (V-SMOW):

$$
\delta^{18} \mathrm{O}=\frac{\left({ }^{18} \mathrm{O} /{ }^{16} \mathrm{O}\right) \text { sample-( }\left({ }^{18} \mathrm{O} /{ }^{16} \mathrm{O}\right)_{\mathrm{V} \text {-smow }}}{\left({ }^{18} \mathrm{O} /{ }^{16} \mathrm{O}\right)_{\text {v-smow }}} \times 1,000 .
$$

The hydrogen-isotopic compositions were determined by analyzing hydrogen quantitatively extracted from water (Kendall and Coplen, 1985). Hydrogen results are reported relative to V-SMOW in per mil notation. The standard deviation of the laboratory measurements of oxygen- and hydrogen-isotopic composition are 0.10 and 1 per mil, respectively. The oxygen- and hydrogen-isotopic compositions were determined at the Isotope Fractionation Project Laboratory of the U.S. Geological Survey, Reston, Virginia.

Tritium was determined by scintillation counting after electrolytic enrichment (International Atomic Energy Agency, 1976). Tritium concentrations are expressed in tritium units (TU), where $1 \mathrm{TU}$ is equal to 1 tritium atom in $10^{18}$ hydrogen atoms. All tritium analyses were done by the Environmental Isotope Laboratory at the University of Waterloo, Ontario, Canada.

Samples of aquifer solids.--Samples of aquifer solids collected for chemical analysis during the drilling process were air-dried and ground to a fine powder. The samples were then subjected to the extraction and digestion procedure described by Fujii and others (1988). All constituents except arsenic and selenium were analyzed using inductively coupled plasma optical emission spectrometry (ICPS) (Thornton, 1983).

Samples for the determination of arsenic and selenium concentrations were subjected to the digestion procedure described by Briggs and Crock 
(1986). The digested sample then was analyzed by hydride generation followed by atomic absorption spectrometry (Briggs and Crock, 1986).

Total organic carbon was determined as the difference of total carbon (measured by oxidizing the sample in an induction furnace) and total inorganic carbon (measured by treating a sample with acid, heating it, and measuring the amount of carbon dioxide evolved) (Wershaw and others, 1987).

Air-dried and ground core samples also were analyzed to determine percentage of sand, silt, and clay. Analyses were done at the U.S. Geological Survey Sediment Laboratory, Salinas, California, and the University of California Agricultural Extension Laboratory, Davis, California. The fraction of sand, silt, and clay was determined by the sieve-pipet and chemically dispersed analysis method (Guy, 1969). Samples were divided into three grain-size classes: less than 50 percent sand, 51 to 70 percent sand, and greater than 70 percent sand. The textural distribution of the wells in the northwest transect were estimated on the basis of field observations during drilling.

\section{DATA PRESENTATION AND INTERPRETATION}

Data for field measurements, major ions, dissolved organic carbon, stable isotopes, and tritium are shown in table 3 (at back of report) and concentrations of dissolved trace elements are shown in table 4 (at back of report).

Differences in chemical compositions of ground water were evaluated using trilinear diagrams (Hem, 1985) and the chemical equilibrium model WATEQF (Plummer and others, 1976). Mineral phases affecting the ground-water chemistry were assessed using mineral saturation indices determined by the WATEQF chemical equilibrium model. The saturation index is equal to the quotient of the ion-activity product and mineral-solubility constant. Negative saturation index values indicate mineral undersaturation and positive values indicate supersaturation. The hydrologic history of selected water samples was assessed from the determination of tritium concentrations and deuterium and oxygen-18 enrichment.

Results of chemical analysis of drilling-core samples collected in the field are shown in table 5 (at back of report). Principal-component analysis
(Johnson and Wichern, 1982) was used to assess chemical associations in the solid phase. Principalcomponent analysis apportions the total variance of the soil chemical data among several master variables (the principal components). Principal-component scores are calculated for each soil sample and constituent determined in the soil samples. The scores have a mean of 0 and a variance of 1 . The elements and the samples are related to the principal components by the value of the scores. The value of the principalcomponent score is analogous to the correlation between the concentration of the constituent in the sample and the principal component.

\section{SPATIAL DISTRIBUTION OF CHEMICAL CONSTITUENTS AND ISOTOPES IN GROUND WATER}

\section{SELENIUM, SALINITY, AND ISOTOPES}

The vertical distribution of selenium in the ground water is related to evapoconcentration of solutes in the shallow ground water and the downward displacement of ground water. Figure 3 shows the selenium concentrations in samples collected in the observation wells. For multiple samples, the number reported in figure 3 is the average of all samples collected from the observation well. In general, selenium concentrations are larger in samples collected from wells at cluster sites in the southeast relative to the northwest section of the field. The higher selenium concentrations in observation wells in the southeast are the result of prolonged evapotranspiration from a shallow water table relative to the northeast in the 1970's. The vertical distribution of selenium concentrations reflects the downward displacement of ground water that was near land surface in the 1970's.

Figure 4 shows the depth distribution of selenium concentrations in ground-water samples. The selenium concentrations in samples collected from the 3and 4-m-deep wells were combined and represented at $3 \mathrm{~m}$ in figure 4 . Similarly, samples collected in 8.5- and 9-m-deep wells were combined and represented at $9 \mathrm{~m}$. The ground-water samples having the largest selenium concentrations were collected at the 9-m depth. Based on tritium and stable isotope data, ground water at the 9-m depth was near land surface in the late 1960's to early 1970's. The high selenium concentrations in the samples from the 9-m depth and, to a lesser extent, the 6-m depth are the result of 


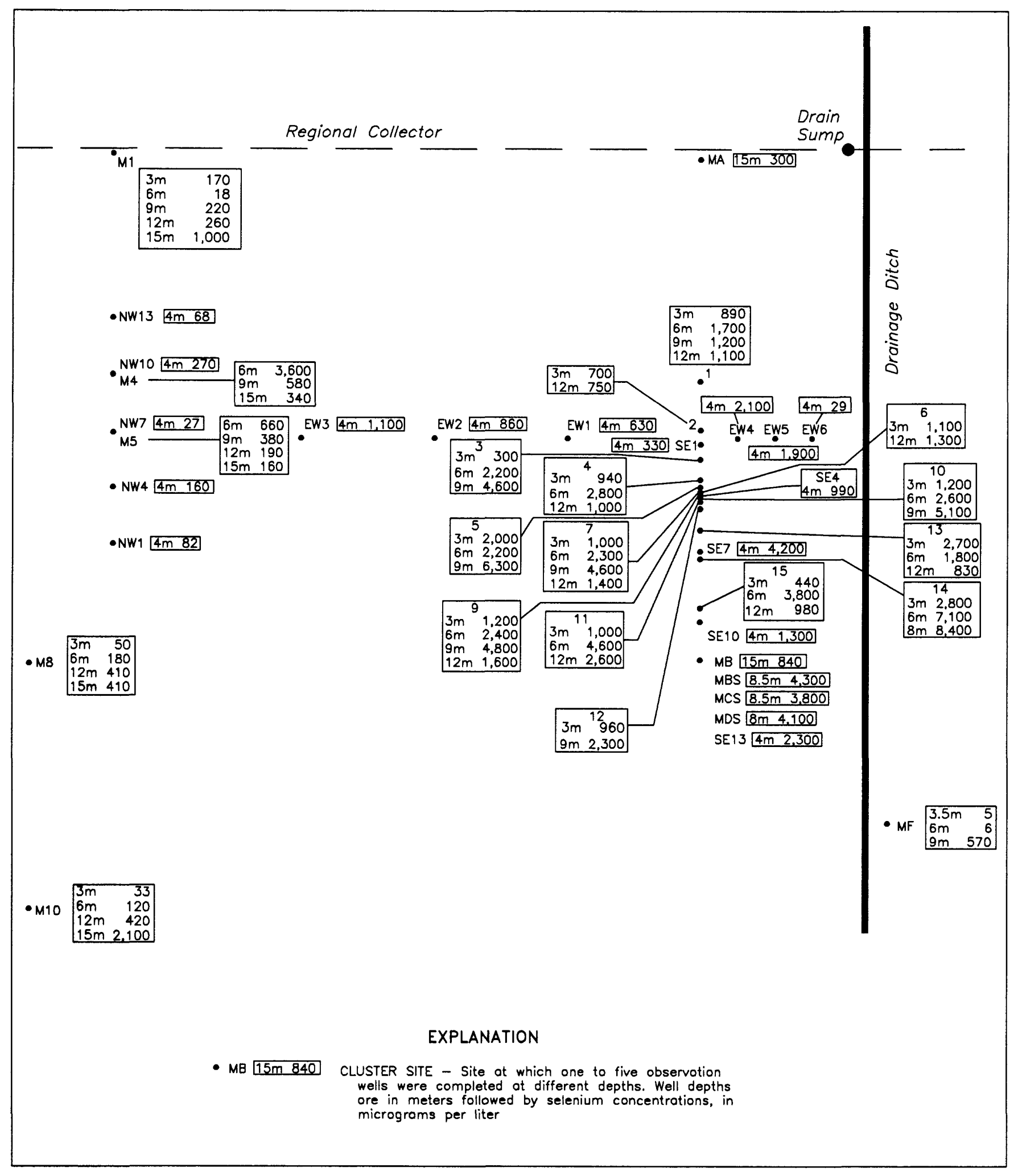

Figure 3. Distribution of selenium concentrations in ground water. 


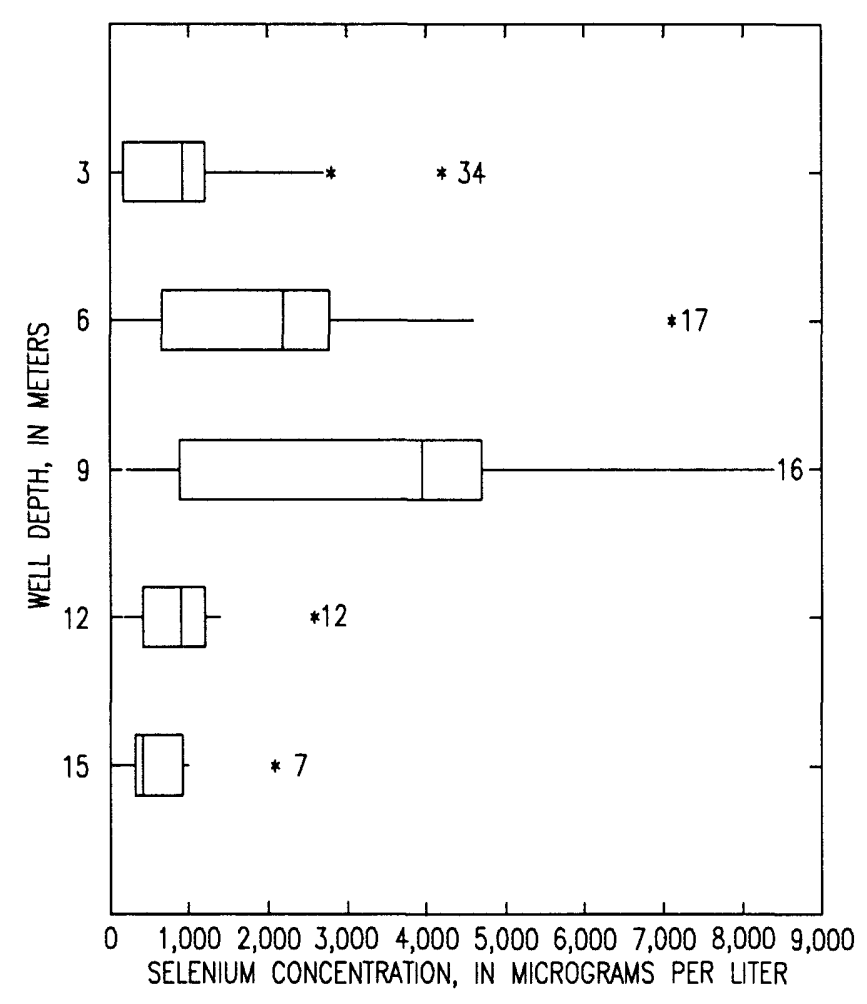

EXPLANATION

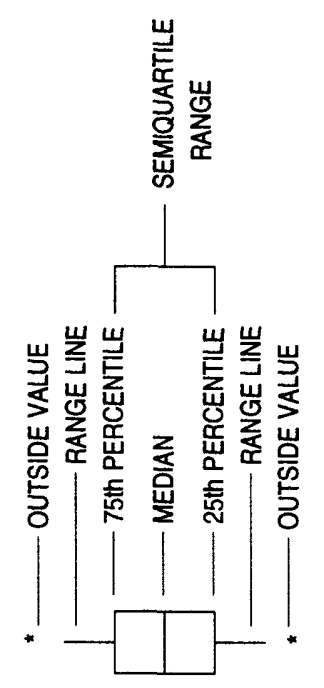

Outside values are between 1.5 and 3.0 times the semiquartile range from the end of the rectangle

Range lines extend a distance equal to 1.5 times the semiquartile range away from the end of the rectangle or to the limit of the data, whichever is least

7 Number of observations

Figure 4. Depth distribution of selenium concentrations in ground water. Average concentrations were used for wells where multiple samples were collected. evapotranspiration from a shallow water table. The ground water at the 6- and 9-m depths was displaced by water that infiltrated primarily after 1970 . The shallowest ground water at $3 \mathrm{~m}$ has lower selenium concentrations because it infiltrated after drainagesystem installation in 1980. The lowering of the water table to below $1.5 \mathrm{~m}$ after drainage-system installation in 1980 resulted in less evapotranspiration of the shallow water table, resulting in lower selenium concentrations.

Ground-water salinity as determined by the concentration of dissolved solids varies similarly to selenium in ground water and is affected by the same processes. The $\operatorname{logs}_{10}$ of dissolved solids and selenium concentrations in ground water are significantly correlated ( $r=0.76, \alpha=0.01$ ). Figure 5 shows the relation of the $\log _{10}$ of dissolved solids and the $\log _{10}$ of selenium concentrations.

The stable isotope enrichment in ground-water samples confirm that the highest selenium concentrations and salinity in ground water are the result of evapotranspiration from a shallow water table. Both selenium concentrations $(r=0.93)$ and salinity $(r=0.91)$ are highly correlated with delta oxygen-18 $\left(\delta^{18} \mathrm{O}\right)$. Figure 6 shows the relation of delta deuterium $(\delta \mathrm{D})$ to $\delta^{18} \mathrm{O}$ for the ground-water samples collected in the field. All the samples fall along an evaporative trend line similar to that described by Deverel and Fujii (1988) and Deverel and Gallanthine (1989). Water

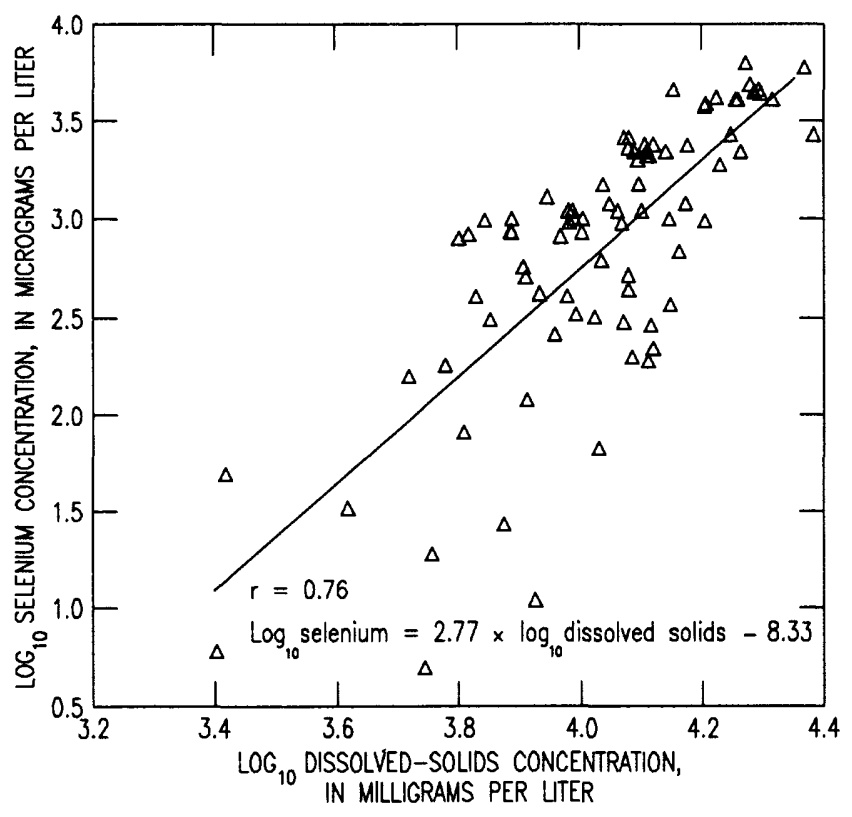

Figure 5. Relation of $\log _{10}$ selenium concentrations and $\log _{10}$ dissolved-solids concentrations for ground-water samples. 


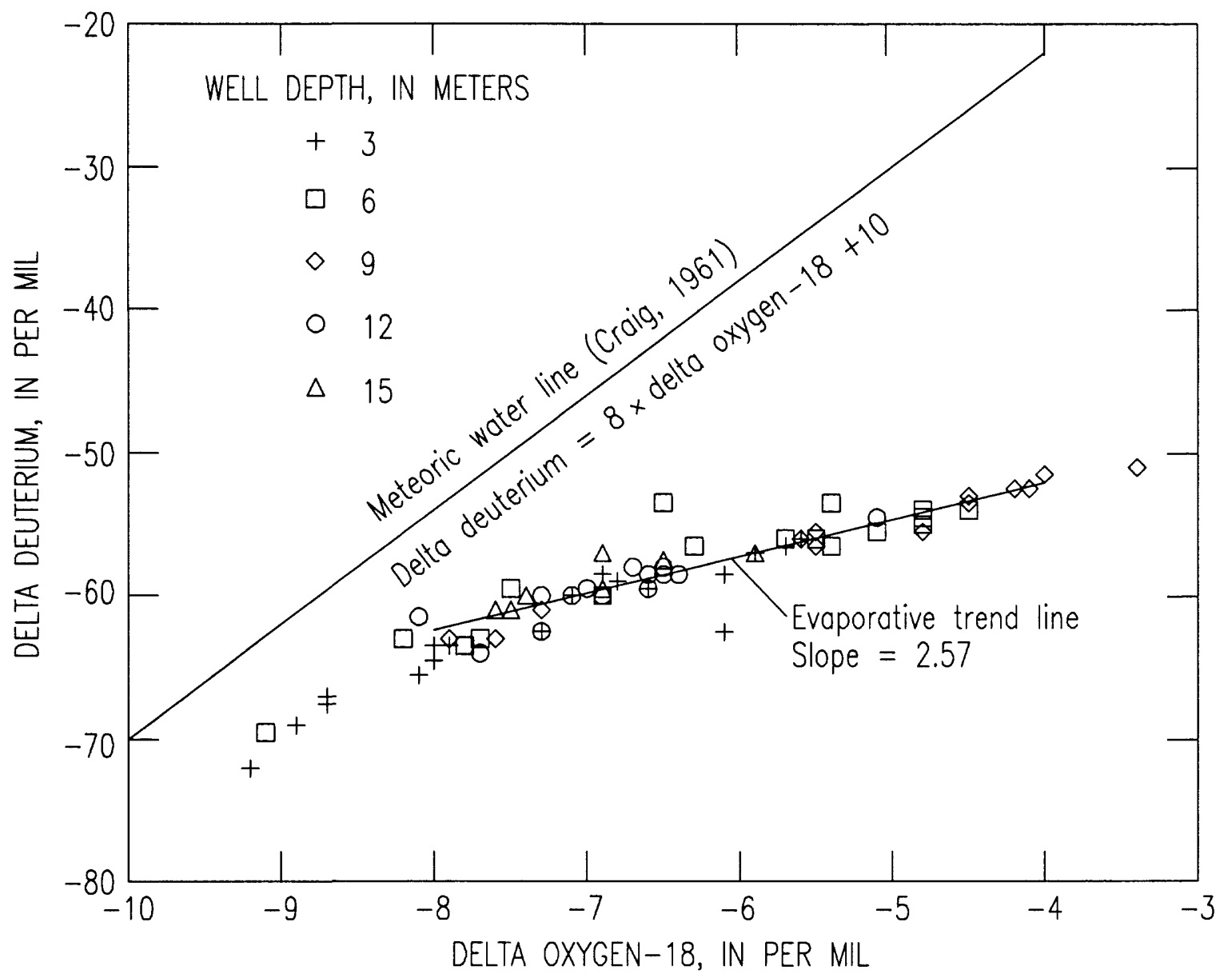

Figure 6. Relation of delta deuterium to delta oxygen-18 for ground-water samples.

samples collected in other arid and semiarid regions also fall along evaporative trend lines (Fontes and Gonfiantini, 1967; Gat, 1971; Zat and Gat, 1975). Samples that show a greater displacement along an evaporative trend line from the meteoric water line have been subject to greater evapotranspiration. The meteoric water line is a relationship established by the isotopic composition of precipitation from samples collected around the world (Craig, 1961). Samples collected at the 6- and 9-m depths have been subject to greater evaporative enrichment of the heavy isotopes than water samples collected at the other depths.

Equilibrium isotopic fractionation results in values that fall on a line with a slope similar to that of the meteoric water line (Craig, 1961) (fig. 6). Evapotranspiration of water from just below land surface is a nonequilibrium fractionation process. Mass transfer of water molecules during evapotranspiration is controlled by diffusion in the region just above the air/water interface. Transport through this region causes kinetic separation, which results in greater enrichment of the oxygen-18 water species than the deuterium water species. Therefore, the ratio of deuterium/oxygen-18 enrichments is lower than would be expected for equilibrium fractionation processes (International Atomic Energy Agency, 1981).

The highest selenium and salinity concentrations were in samples collected at the 6- and 9-m depths (fig. 4) and are the result of the most evaporative concentration. The samples collected at the 3-m depth generally have isotopic compositions that are close to the meteoric water line and have been subject to less evaporative concentration (fig. 6). This is because of the drainage-system installation in 1980 and subsequent lowering of the water table to a depth from which little or no evapotranspiration occurs. 
The points plotted in figure 6 represent an evaporative trend line that is described by the equation:

$$
\delta \mathrm{D}=2.70 \times \delta^{18} \mathrm{O}-41.1(r=0.90) .
$$

The slope of this line is significantly $(\alpha=0.01)$ lower than the evaporative trend slope of 4.28 reported by Deverel and Fujii (1988) for shallow ground water collected beneath agricultural fields in the western valley, north of the study site. Allison (1982) presented evidence that such a low slope is the result of prolonged evaporation from a dry surface. Displacement since the mid-1970's of unsaturated-zone water that has been subject to evapotranspiration from a dry soil surface probably has resulted in the present-day pattern of isotopic enrichment in the shallow ground water (fig. 6).

The slope in equation 2 is dominated by points that represent water samples collected at the 6-m depth and below. The equation of the evaporative trend line for water samples collected at $3 \mathrm{~m}$ is:

$$
\delta \mathrm{D}=3.21 \times \delta^{18} \mathrm{O}-38.5(r=0.96) \text {. }
$$

The oxygen-18 value at the intercept of this line with the global meteoric water line is -10.13 . This value is close to the median of measured values for data collected by the authors for the past 2 years from the California Aqueduct (-9.55).

Equation 2 is significantly different $(\alpha=0.01)$ from the equation representing the data from the 6- and 9-m depths,

$$
\delta \mathrm{D}=2.37 \times \delta^{18} \mathrm{O}-42.7(r=0.92) .
$$

The $\delta^{18} \mathrm{O}$ intercept of this line with the local ground water trend line is -7.99 , close to the mean of -8.59 for the confined aquifer water used for irrigation prior to 1970 (Davis and Coplen, 1987).

The difference in the slopes between the two groups of data indicates different evaporative processes. The lower slope for the 6- and 9-m data may be the result of prolonged evaporation from a dry surface soil. This may have occurred under saline conditions that inhibited crop growth. In contrast, the conditions under which the water at the 3-m depth infiltrated were less saline, and more plant transpiration may have been the primary mechanism of evaporative losses. This resulted in a different slope and a more depleted isotopic composition (Barnes and Allison, 1983). Samples collected from wells at depths of 12 and $15 \mathrm{~m}$ are similar in isotopic composition to the samples collected at the 3-m depth. The water at these lower depths probably infiltrated 25 to 40 years ago and underwent some isotopic enrichment due to evapotranspiration as it traveled through the unsaturated zone.

Below $9 \mathrm{~m}$, ground water is less isotopically enriched than water at the 6- and 9-m depths, yet the selenium concentrations are high [median $=880 \mu \mathrm{g} / \mathrm{L}$ (micrograms per liter)]. The lower isotopic enrichment indicates that selenium in ground water at this depth was the result of leaching of soil salts when the water level was too far from land surface for evaporative enrichment to occur. The tritium data supports this hypothesis.

As a result of nuclear testing, high levels of tritium were introduced into the atmosphere between 1953 and 1969. Water exposed to the atmosphere since 1953 can be expected to have tritium concentrations greater than 5-10 TU (tritium unit) (Freeze and Cherry, 1979). Irrigation water for this field has been imported from northern California by the Federal Central Valley Project since 1970. Figures 7 and 8 show the spatial and depth distribution of tritium in water samples collected from the observation wells. Tritium was detected in all samples collected at the 3-m depth. Samples collected from the 6-m depth had lower tritium concentrations than the 3-m depth and few of the samples from the 9- and 12-m depths had any detectable tritium. The samples collected at the 15-m depths all had less than $1.6 \mathrm{TU}$ except the sample collected from the $15-\mathrm{m}$ well at site M5, which had an average tritium concentration of 18.4 TU (fig. 7). All samples collected at site M5 are high in tritium relative to samples collected from the same depths at other sites in the field.

Water imported from northern California has tritium concentrations of about $10 \mathrm{TU}$ and is now at the 3- and 4-m depths. This water has displaced saline, isotopically enriched water, downward. Because ground water pumped from the deep confined aquifer was used for irrigation until 1970 , present-day samples with low tritium concentrations originated from this source and are now at depths greater than $6 \mathrm{~m}$. Ground water at the 6-m depth generally has low tritium concentrations and represents primarily ground water applied prior to 1970 . Based on the tritium data, the net downward rate of movement is between 0.25 and $0.75 \mathrm{~m} / \mathrm{a}$ since 1970 . This downward movement has been affected in recent years because of drain installation and by addition of water to storage before 1970. The primary source of recharge here is assumed to be irrigation water and not the sparse rainfall. 


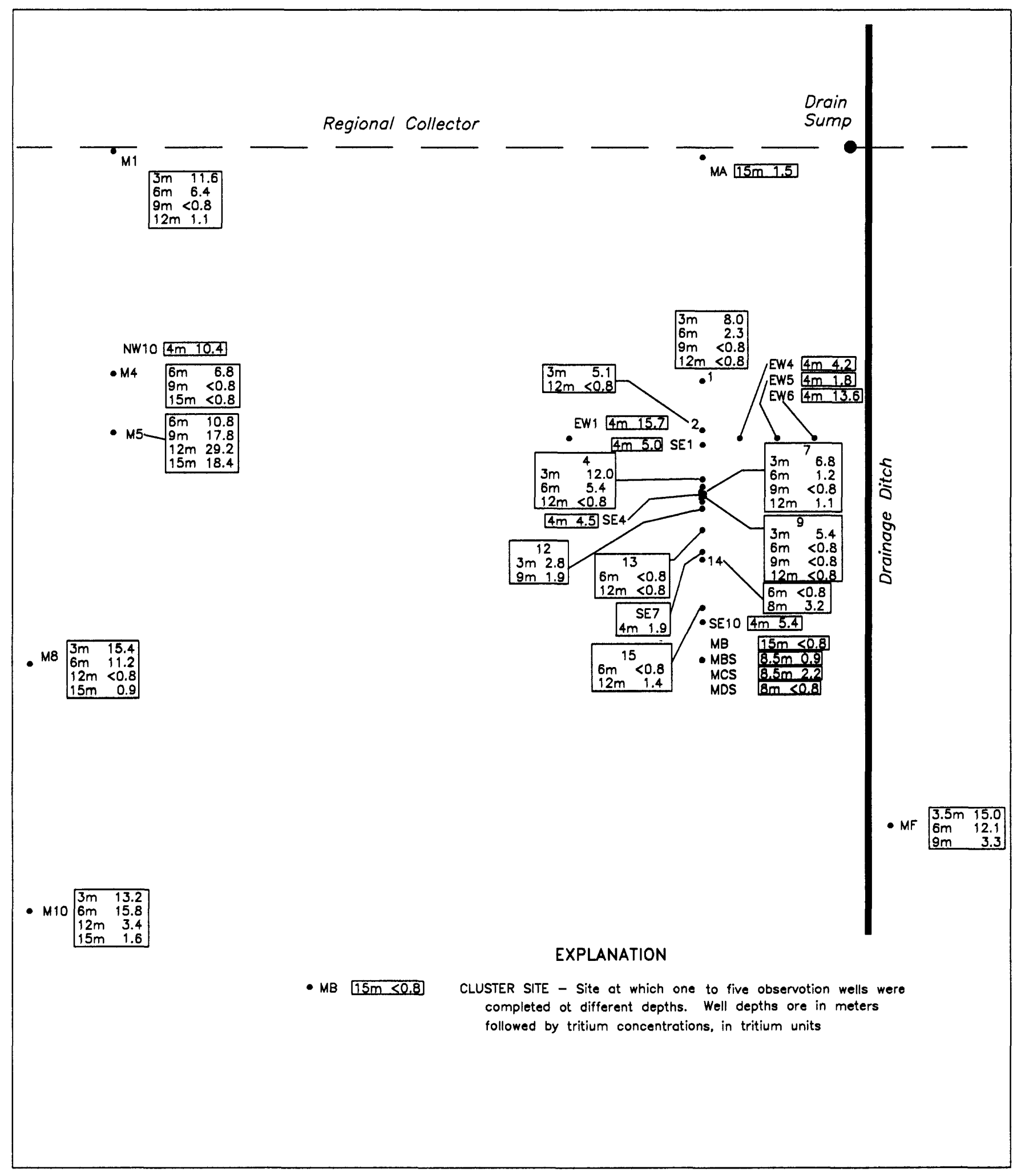

Figure 7. Distribution of tritium concentrations in ground water. Average concentrations shown for wells where multiple samples were collected. 


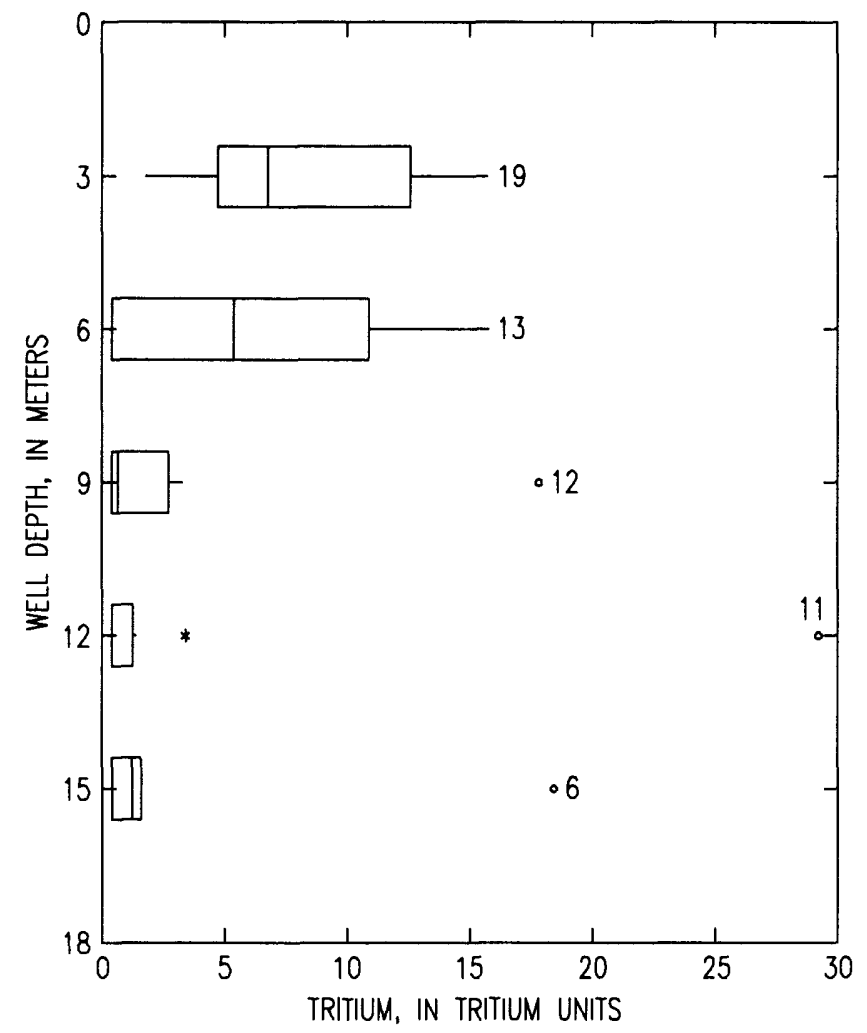

EXPLANATION

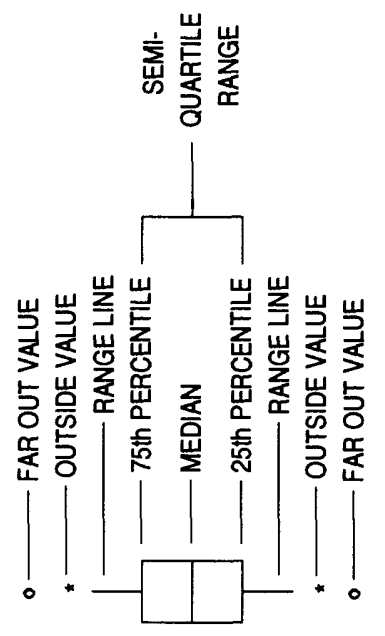

Far out values are more than 3.0 times the semiquartile range from the end of the rectangle

Outside values are between 1.5 and 3.0 times the semiquartile range from the top or bottom of the rectangle

Range lines extend a distance equal to 1.5 times the semiquartile range away from the end of the rectangle or to the limit of the data, whichever is least

6 Number of observations

Figure 8. Depth distribution of tritium concentrations in ground water. Average concentrations were used for wells where multiple samples were collected.

\section{MAJOR IONS}

Trilinear diagrams (Hem, 1985) (fig. 9) show the relation of major-ion chemistry to ground-water salinity as represented by dissolved-solids concentrations. Sodium and sulfate are the predominant species in the more dilute waters. Although sodium and chloride are the dominant ions in water having the highest salinities. As the salinity increases, the higher concentrations of sulfate result in precipitation of gypsum, causing chloride to become more dominant as the sulfate is removed from solution.

Gypsum and calcite saturation indexes were calculated using WATEQF (Plummer and others, 1976). The median gypsum saturation indexes were highest, and indicate generally supersaturated conditions at the 6- and 9-m depths (fig. 10). The saturation indexes in samples collected from the 3- and 4-m wells were combined and represented at $3 \mathrm{~m}$ in figure 4 . Similarly, samples collected in 8.5- and 9-m wells were combined and represented at $9 \mathrm{~m}$. These indexes correspond with the samples with the highest salinities. Virtually all samples were supersaturated with respect to calcite. Precipitation of calcite from solution accounts for the relatively low calcium and bicarbonate at all but the lowest salinities.

\section{OTHER TRACE ELEMENTS}

For the inorganic trace elements determined, figure 11 shows the ranges of concentrations for selected elements with depth. The concentrations determined in samples collected from the 3- and 4-m wells were combined and represented at $3 \mathrm{~m}$ in figure 11 . Similarly, samples collected on 8.5- and 9-m wells were combined and represented at $9 \mathrm{~m}$. The $\log _{10}$ of the concentrations of boron $(r=0.883)$, iron $(r=0.55)$, lithium $(r=0.476)$, selenium $(r=0.773)$, and vanadium $(r=0.453)$ were significantly correlated $(\alpha=0.01)$ with the $\log _{10}$ of dissolved solids. This correlation is consistent with data reported by Deverel and Millard (1988), who reported that boron, selenium, and vanadium are likely present as mobile oxyanions in oxidized ground water and are associated with salinity. The distribution of these trace elements reflects the salinity and geologic origin of the valley alluvial deposits. The field is in alluvial-fan material exclusively derived from the California Coast Ranges. Boron, selenium, and vanadium are present in the Coast Ranges source material and thus have similar relations to salinity. Molybdenum seems to be associated with the Sierra Nevada deposits (Deverel and Millard, 1988) and does not show a statistically significant correlation with salinity in this study. 


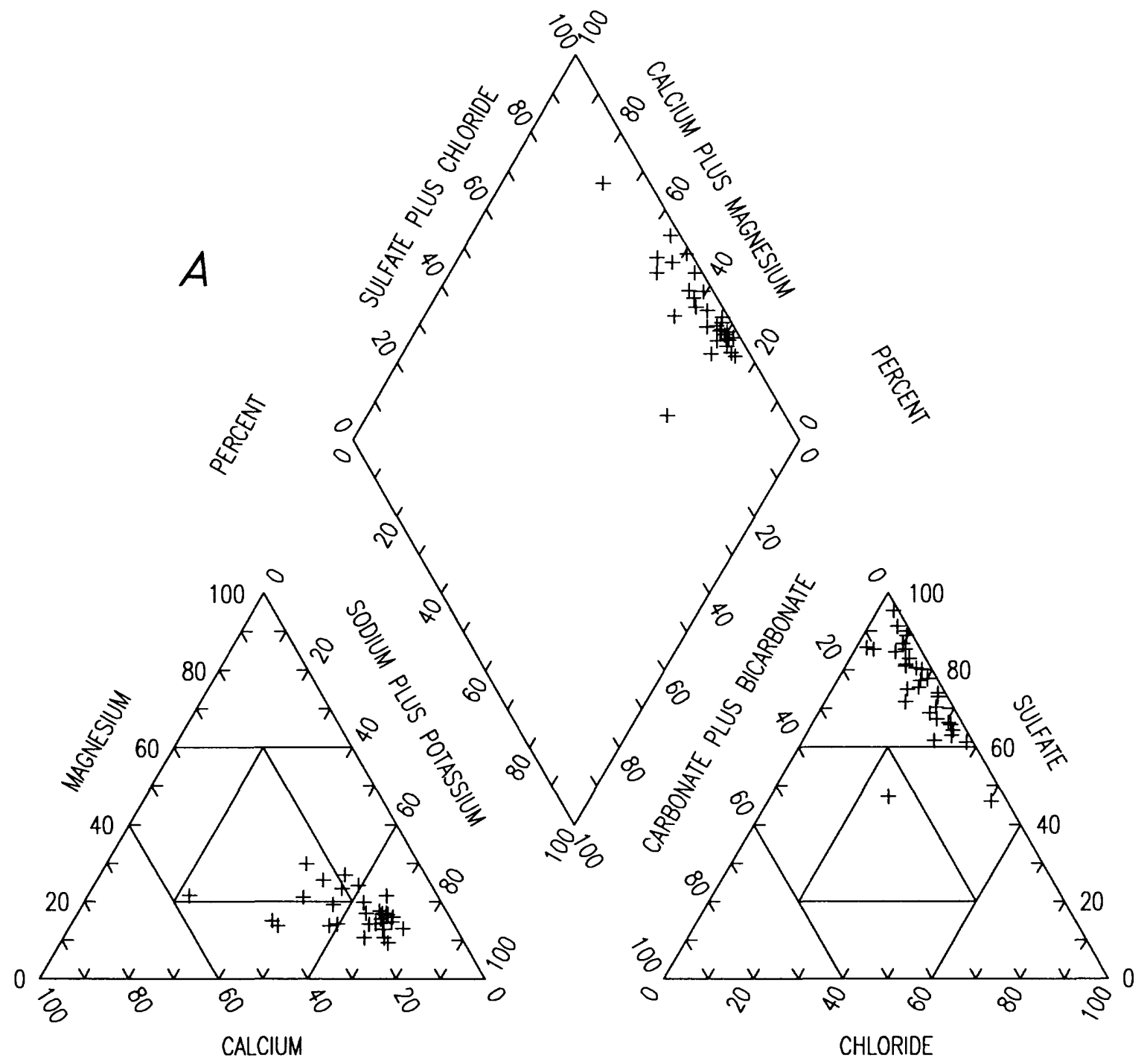

PERCENTAGE OF TOTAL MILLIEQUIVALENTS PER LITER

Figure 9. Relation of major-ion chemistry to ground-water salinity. A, Dissolved solids less than $12,000 \mathrm{mg} / \mathrm{L}$. B. Dissolved solids greater than $12,000 \mathrm{mg} / \mathrm{L}$.

\section{TEMPORAL VARIABILITY OF CONSTITUENTS IN GROUND WATER AND DRAINWATER}

\section{GROUND WATER}

Selected wells were sampled several times during the study period to assess the temporal variability of the ground-water chemistry. Selenium concentrations, dissolved solids, and stable isotope data for wells with multiple samples are shown in table 6 (at back of report). Thirty-seven wells had multiple samples collected more than 2 months apart and were used for this analysis. Although the selenium concentrations and salinity varied with time, the temporal trend in the data is not statistically significant.

There were 22 wells with multiple analysis of the stable isotopes. Over time, 16 wells became more depleted in deuterium and 14 wells became more depleted in oxygen-18. Multiple samples collected in 14 of 15 wells in the coarse-grained deposits became more depleted in both stable isotopes. This general trend of depletion of the stable isotopes probably is the result of the downward movement of water from the 3- and 4-m depths. This shallow ground water was subject to less evaporative concentration than water at the 6- and 9-m depths. 


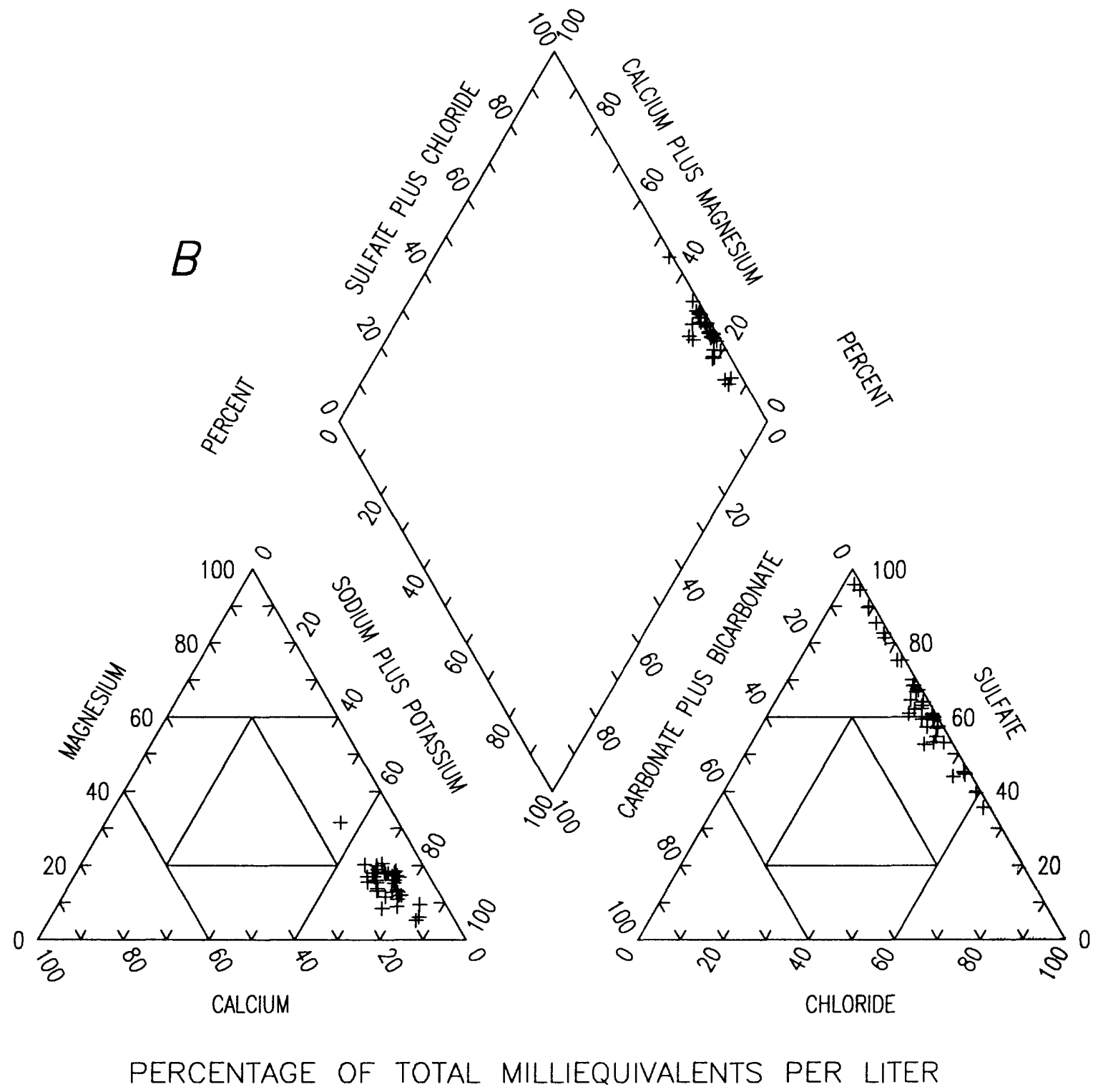

Figure 9. Continued.

\section{DRAINWATER}

The drain laterals in the drained agricultural field lead into the field collector line which leads into a drain sump in the northeast corner of the field (fig. 3). Water in the field collector was collected and analyzed periodically. Table 7 (at back of report) contains the results of the analysis of these samples. Figure 12 shows selenium and dissolved-solids concentrations and delta oxygen- 18 values for the drainwater plotted over time. Concentrations of these constituents vary substantially, but two peaks are evident. The first peak was in September 1986, and the second was during November and December 1987 and January and February 1988. These peaks coincide with periods of high ground-water levels that were the result of irrigation.

Increased hydraulic gradients toward the drain laterals result in increased flow into the laterals. As irrigation water is applied to the field, saline ground water is displaced toward the laterals. This displacement results in an increase in the selenium concentrations and salinity of the drainwater. This displaced ground water also is enriched in the stable isotopes, and the drainwater reflects this change in isotopic 


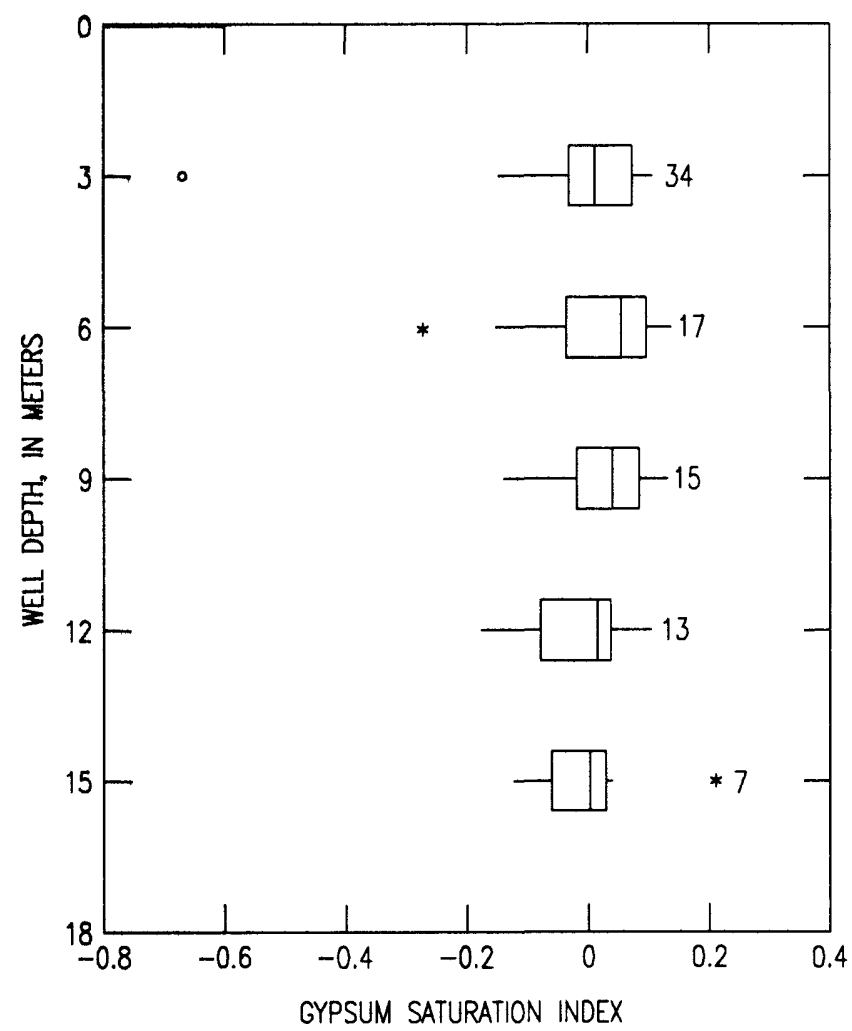

Figure 10. Depth distribution of gypsum saturation indexes. Average concentrations were used for wells where multiple samples were collected. composition. As hydraulic heads return to preirrigation levels, the amount of water entering the drain laterals decreases. Ground water does not flow into the drain laterals during fallow periods.

Water from the sump is pumped into a drainage ditch that runs along the eastern edge of the field. Excess surface water from this and other nearby fields also is collected in this ditch. Water in the ditch seeps into the field collector. Because of the diluting effect of the less saline, isotopically depleted excess surface irrigation water, the water from this ditch is less saline and isotopically depleted relative to the shallow ground water. The seepage of this ditch water into the field collector causes the water collected at the sump to be less saline and isotopically depleted than would be expected if the sump water consisted of drainwater from the field only.

During the nonirrigated seasons, flow in the field collector line is primarily from seepage from the ditch, because the drain laterals collect ground water only during the irrigation season. The increase in the selenium concentrations, salinity and isotopic enrichment of the drainwater during the irrigation events as shown in figure 12 is due to ground-water flow to the drain laterals. This water has higher selenium concentrations, salinity, and greater isotopic enrichment than the water in the ditch. Evaluations of the

\section{EXPLANATION FOR FIGURES 10 AND 11}

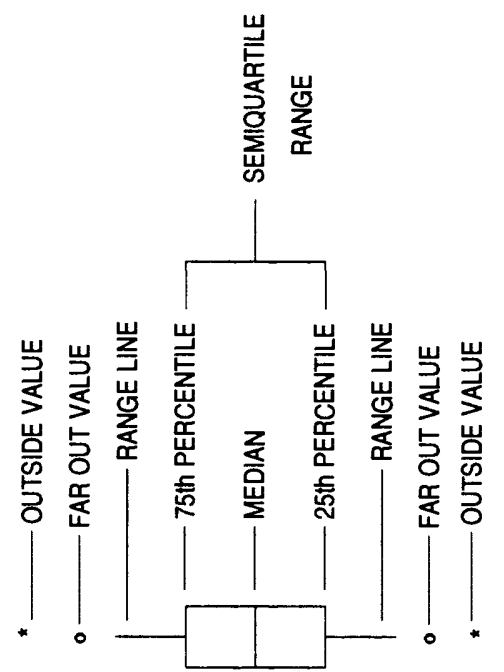

Outside values are between 1.5 and 3.0 times the semiquartile range from the end of the rectangle

Far out values are more than 3.0 times the semiquartile range from the end of the rectangle

Range lines extend a distance equal to 1.5 times the semiquartile range away from the end of the rectangle or to the limit of the data, whichever is least 7 Number of observations 

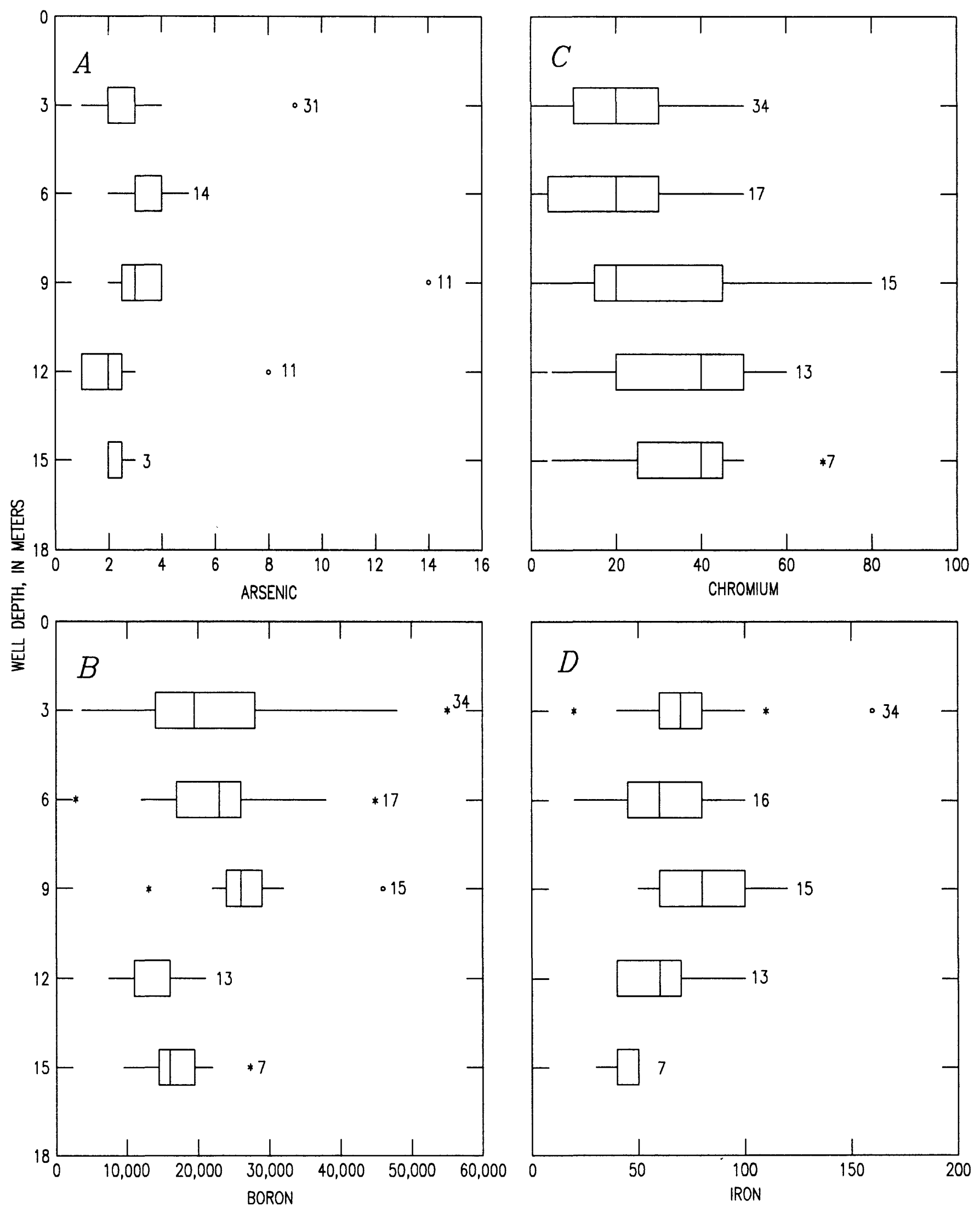

CONCENTRATION, IN MICROGRAMS PER LITER

Figure 11. Depth distribution of selected trace elements. Average concentrations were used for wells where multiple samples were collected. 

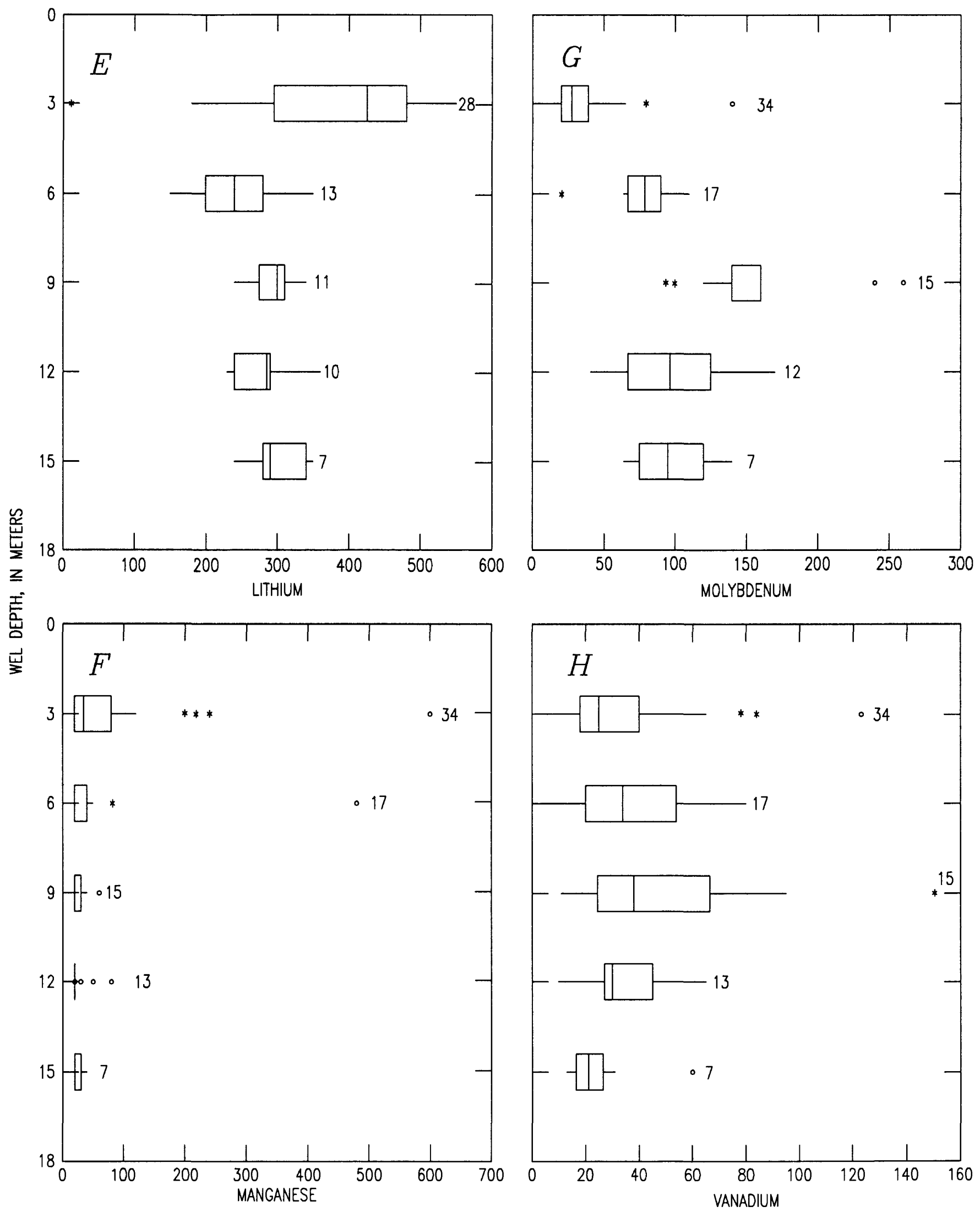

CONCENTRATION, IN MICROGRAMS PER LITER

Figure 11.--Continued. 

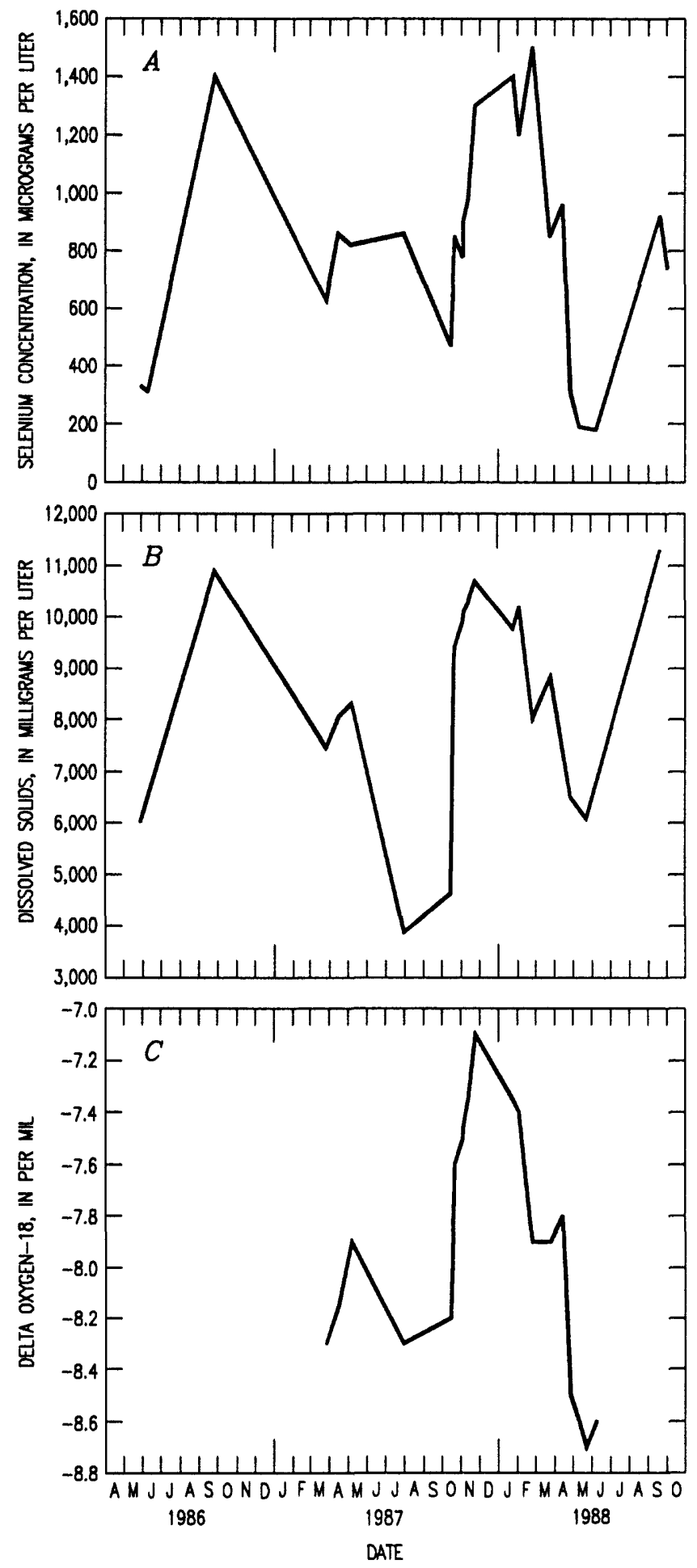

Figure 12. Selenium and dissolved-solids concentrations and delta oxygen-18 ratio measured over time for the drain sump. ground-water-flow patterns provide further insight into the processes affecting the temporal and spatial variability of the chemical and isotopic composition of ground water and drainwater.

\section{GROUND-WATER-FLOW PATTERNS}

Ground-water hydraulic gradients in the field change substantially over time. During the irrigation season, gradients are primarily vertically downward. During fallow periods, gradients are primarily upward. The stratigraphy, notably the presence of subsurface sand lenses and the presence of regional collector drains, substantially influences the direction of ground-water flow.

Hydraulic head was recorded continuously at sites 7 and 14 and is shown in figure 13. For both sites, substantial rises in hydraulic head are the result of irrigation during the summer of 1986 and autumn of 1987. A reversal in gradients is illustrated further by an examination of the distribution of hydraulic heads in the two cross sections in the field.

Figure 14 shows the distribution of hydraulic head superimposed on existing sand layers along geohydrologic section $A-A^{\prime}$ during periods of high and low hydraulic heads. The hydraulic heads representative of an irrigation period were measured August 11, 1986, and those representative of a nonirrigation period were measured April 9, 1986 (figs. 13 and 14). The means of the head values for sites 6 through 12 were used in the central part of the diagram. Lines of equal hydraulic head and generalized directions of ground-water flow represent a qualitative-flow net (Freeze and Cherry, 1979) and are based on the anisotropy in the fine-grained material. The horizontal and vertical axes were drawn based on the horizontal and vertical conductivities for the fine-grained material reported by Fio and Deverel (1990). As described by Freeze and Cherry (1979), the ratio of $x$ to $y$ axis is proportional to the ratio of the square roots of the hydraulic conductivities in the horizontal and vertical directions.

During irrigation, flow is primarily downward. The sand lens present at sites 13,14 , and 15 seems to influence flow substantially. At site 15, for example, flow is toward the sand layer from above and below. Lower hydraulic heads in the sand lens are probably the result of relatively higher flow in the sand lens 


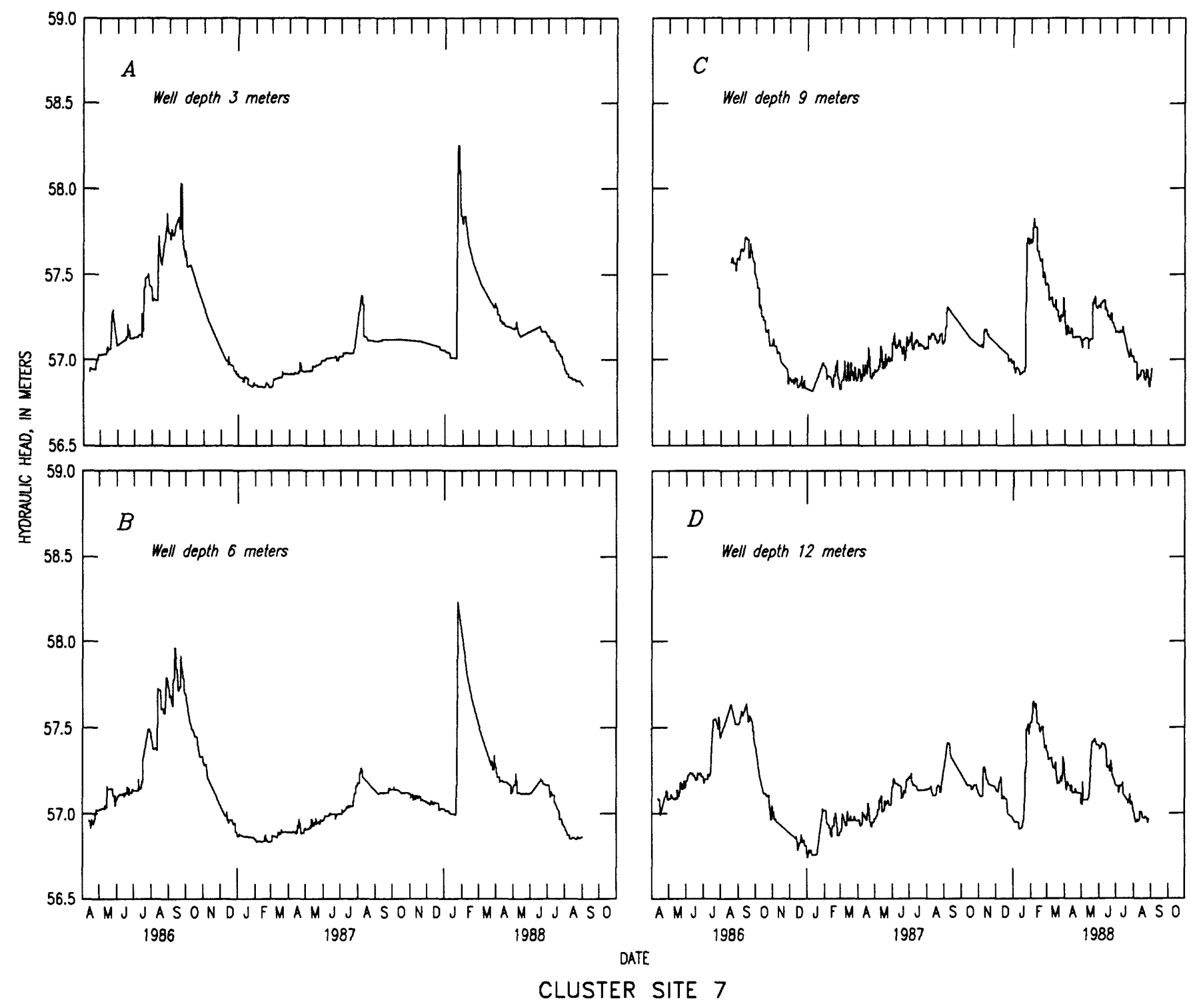

Figure 13. Changes in hydraulic head for wells at sites 7 and 14 .

which is influenced by ground-water flow to the regional collector (fig. 2). Except during and immediately after an irrigation event, the drain laterals do not substantially influence ground-water flow.

During nonirrigation periods, the drain laterals do not flow and gradients are primarily upward. The hydraulic gradient at site 15 is changed relative to the irrigated period with flow apparently through the sand layer. In both cases, there is a horizontal gradient within the sand layer from site 15 to 14 . Irrigation causes hydraulic heads to increase everywhere in the cross section. Following irrigation, this increase in hydraulic head dissipates rapidly in the sand lens because of its high hydraulic conductivity and discharge to the collector drain, causing flow into the sand lens from the fine-grained aquifer material below.

Figure 15 shows the distribution of lines of equal hydraulic head and generalized directions of groundwater flow for geohydrologic section $B-B^{\prime}$ during high and low hydraulic head periods. There were no distinct sand layers in geohydrologic section $B-B^{\prime}$. The texture of the deposits is discussed in the following section. These periods probably corresponded to irrigation periods. Irrigation was done at different times in this area of the field relative to the area 


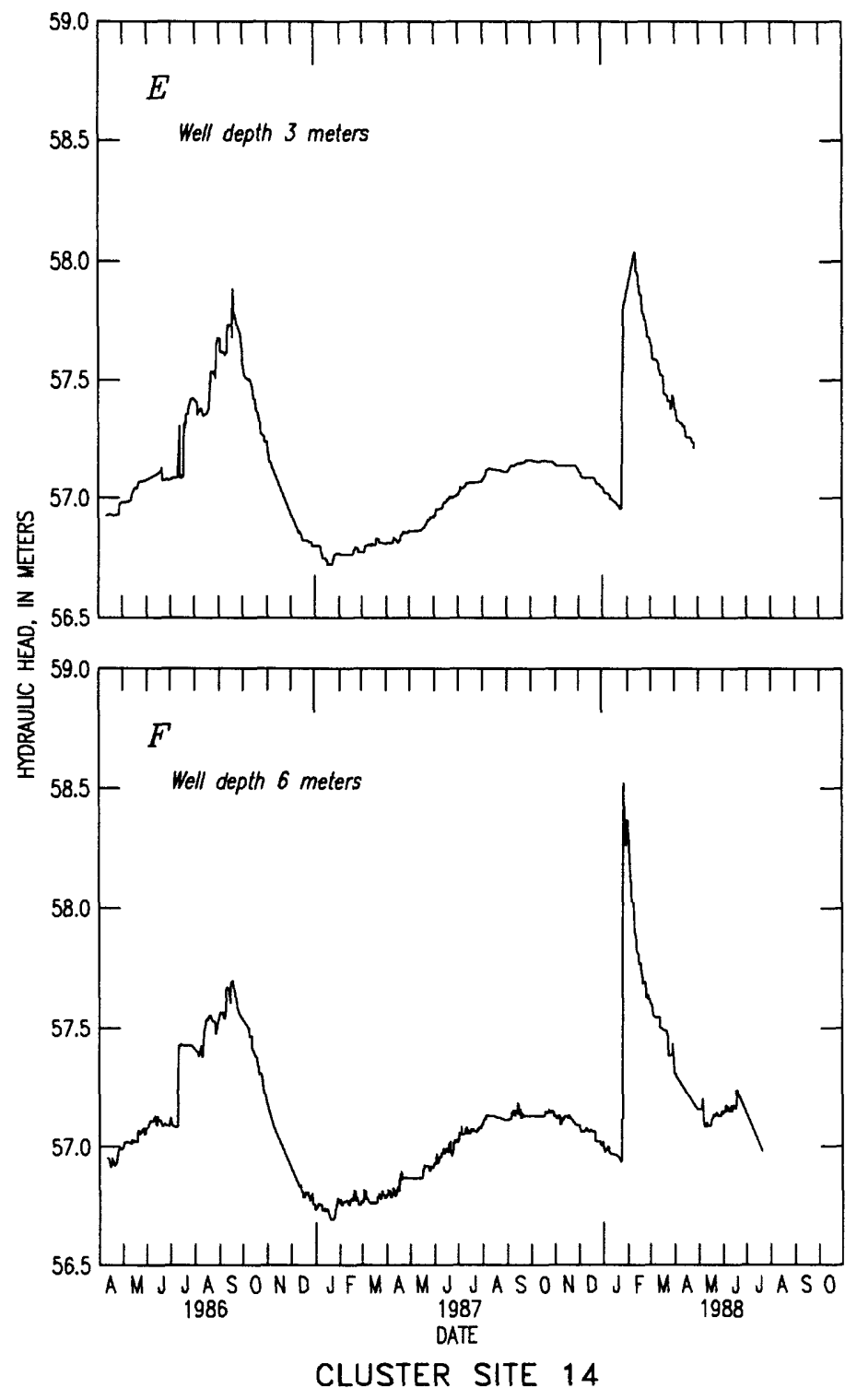

Figure 13. Continued.

encompassing the $A-A^{\prime}$ section. Hydraulic gradients are similar to those calculated for section $A-A^{\prime}$. In contrast to the geohydrologic section $A-A^{\prime}$, hydraulic gradients were determined adjacent to the regional collector at the 3-, 6-, 9-, 12-, and 15-m depths at the site M1. The hydraulic gradient is always toward the regional collector, which acts as a discharge zone. During the high hydraulic head period, downward flow is greater at all sites relative to the low hydraulic head period. Ground-water flow may also be influenced by regional, topographically driven flow from southwest to northeast.

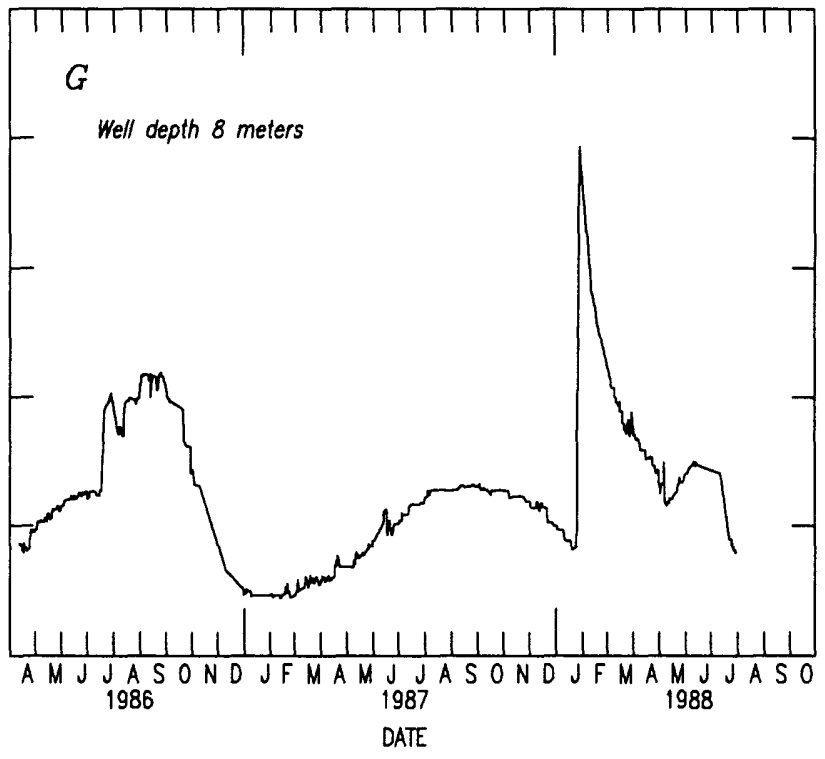

The horizontal gradients at the 3-m depths for the entire field are shown in figure 16 . The hydraulic head at the regional collector was calculated by assuming zero pressure head at the depth of the regional collector line. The depth of the collector line was determined from installation diagrams (U.S. Bureau of Reclamation, Geology Branch, written commun., 1988). The generalized direction of flow reflects discharge to the regional collector and the field collectors and topographically driven flow. The topographic contours mapped in this field (U.S. Geological Survey Topographic Map, 7.5 Minute Series--Coit Ranch Quadrangle) show a decrease in altitude from west to east of about $5 \mathrm{~m}$.

The lines of equal hydraulic head and generalized flow directions provide information about groundwater movement in the field. This information combined with information about hydraulic characteristics and texture can allow a more quantitative assessment of directions and rates of ground-water flow.

\section{PHYSICAL FACTORS AFFECTING GROUND-WATER FLOW}

Ground-water-flow patterns described in the previous section are influenced by the texture of the alluvial deposits which in turn influences the hydraulic conductivity. 


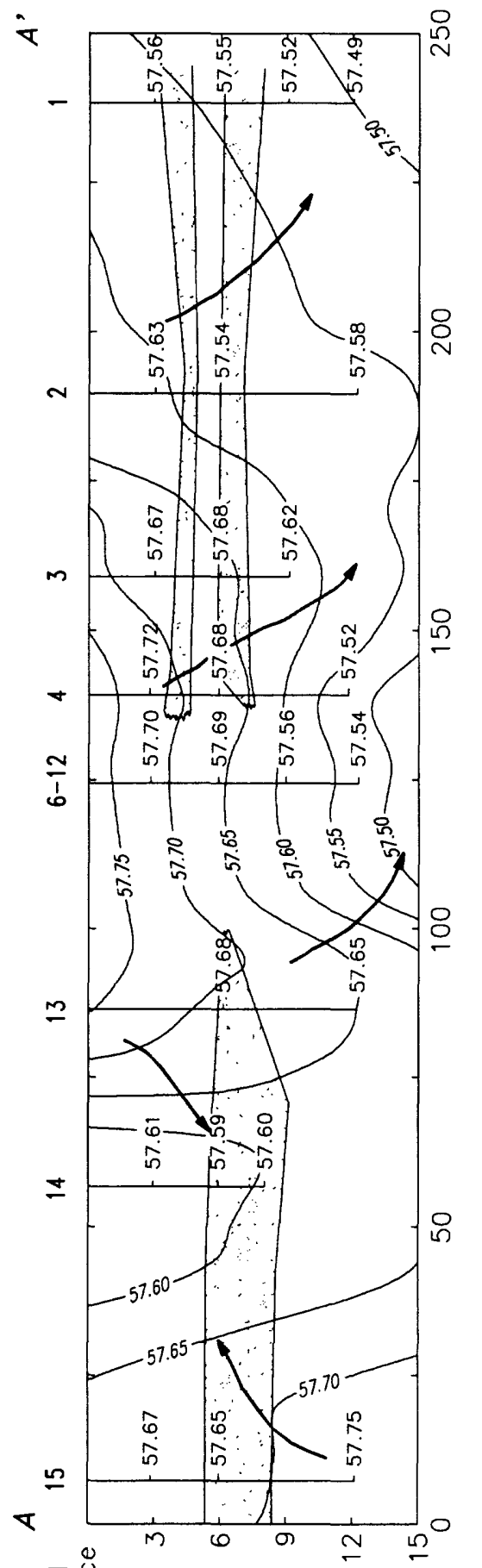

导导导
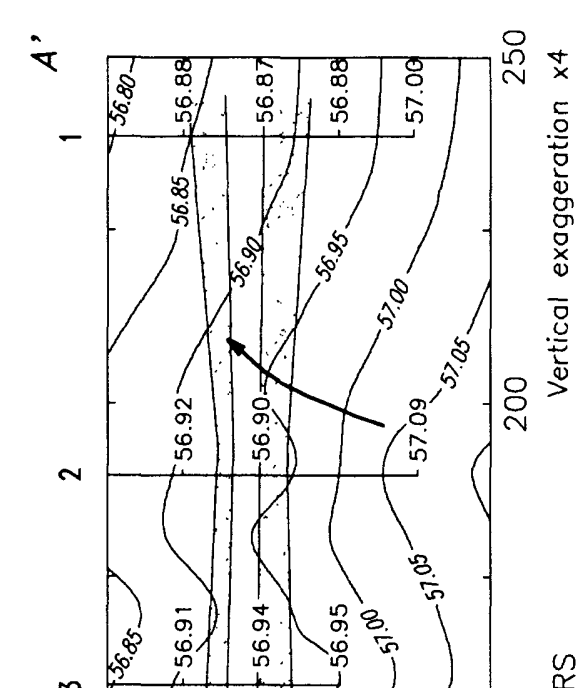

足

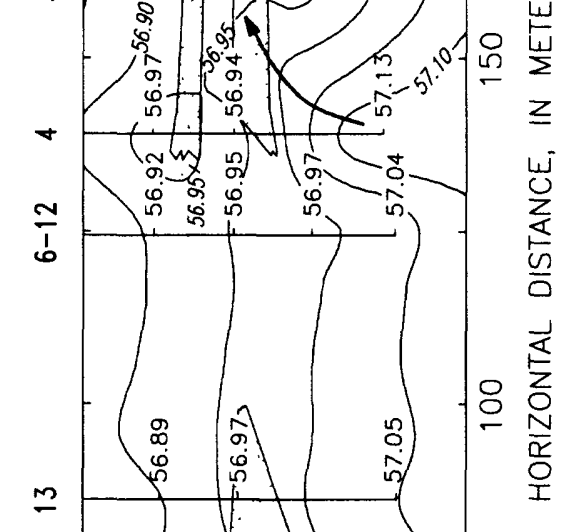

它 $\quad$ ᄃ

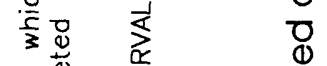

㐫岕|

部

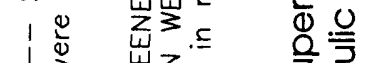

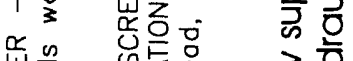

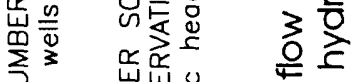

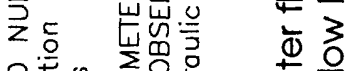

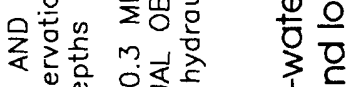

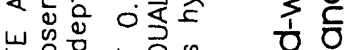

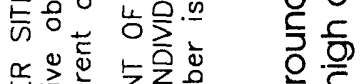

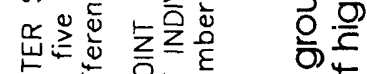

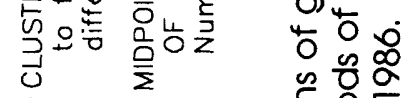

1 -

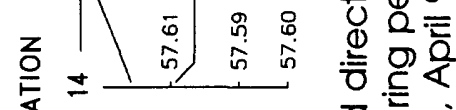

잉

Nㅡㅇ

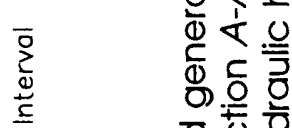

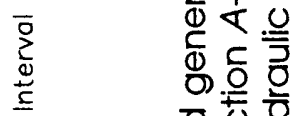
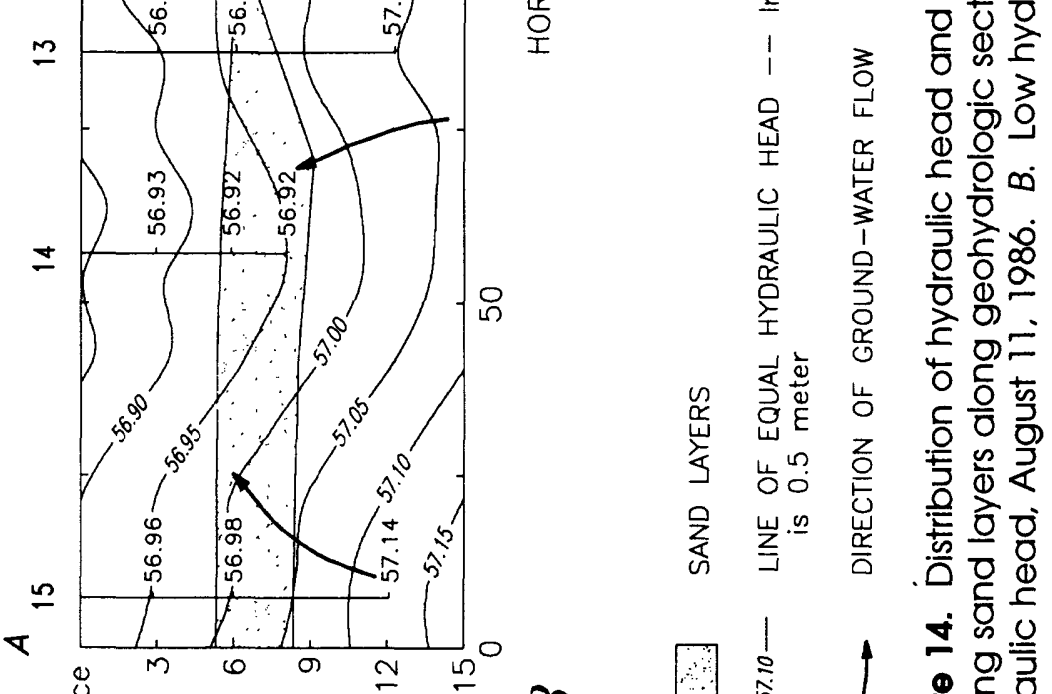

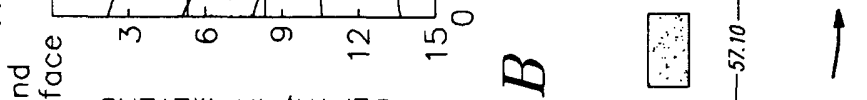

을

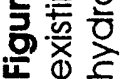



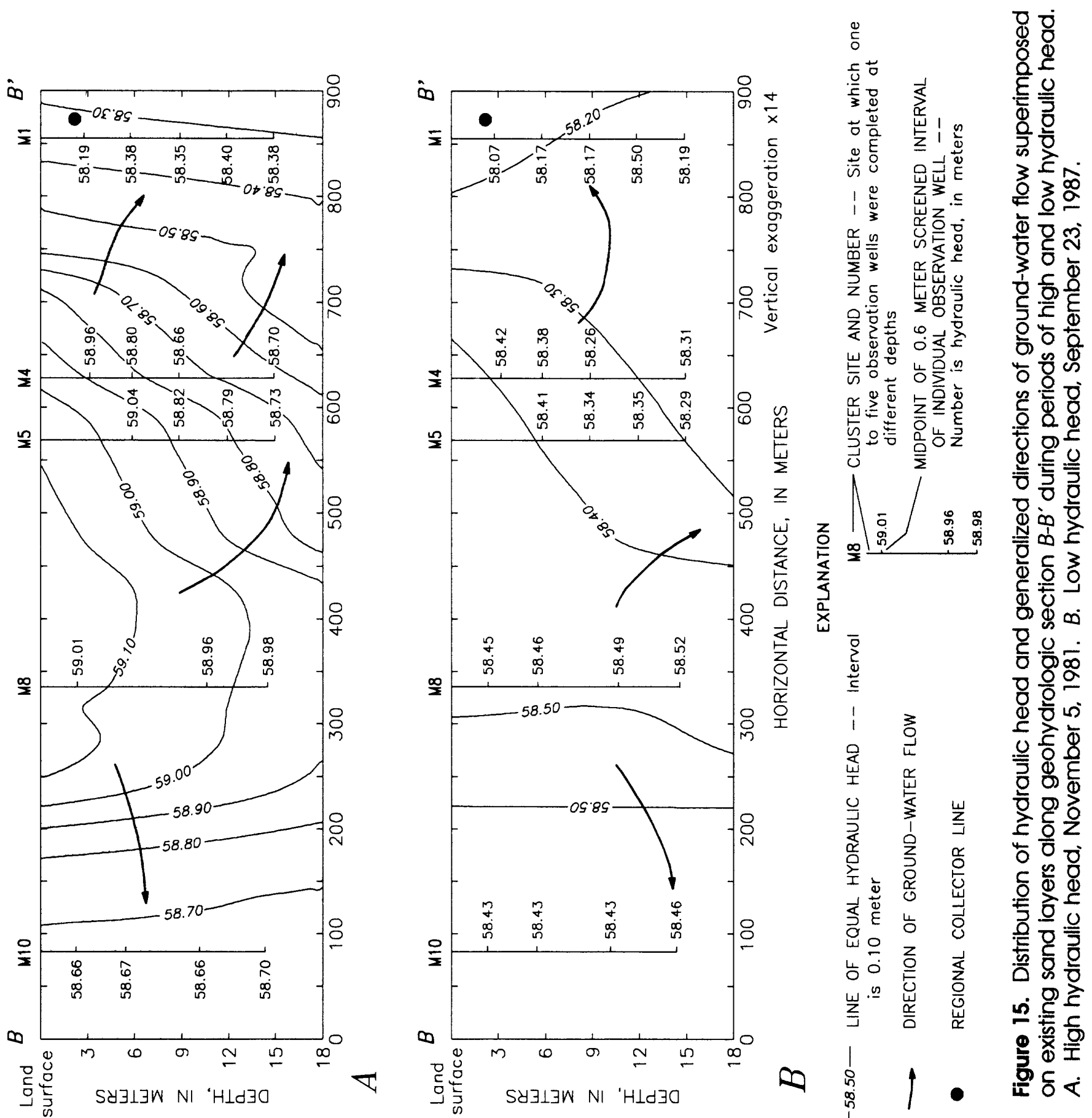

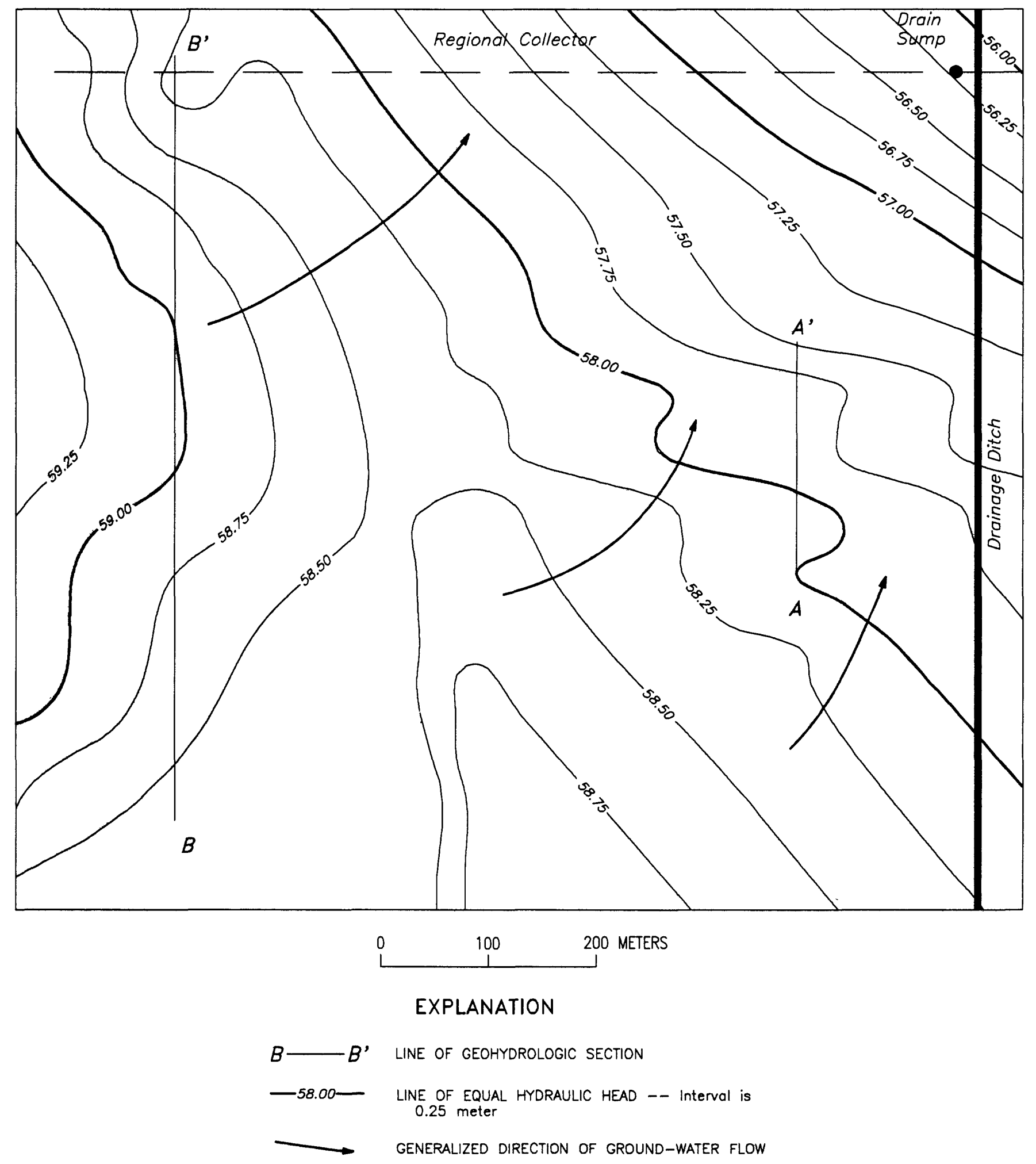

Figure 16. Areal distribution of hydraulic head 3 meters below land surface and generalized direction of ground-water flow. 


\section{TEXTURE}

The texture distribution in the samples of aquifer material collected from this field indicate that the grain size of geologic deposits in this field generally become more coarse with increasing depth. This texture distribution is in agreement with information presented by Laudon and Belitz (1991) who studied the texture of near-surface alluvial deposits in the central San Joaquin Valley. Figure 17 shows the texture distribution of geohydrologic sections $A-A^{\prime}$ and $B-B^{\prime}$. Geohydrologic section $A-A^{\prime}$ shows that the top $6 \mathrm{~m}$ are predominately fine grained in the southeast part of the field. Geohydrologic section $B-B^{\prime}$ indicates that the top $6 \mathrm{~m}$ of the deposits in the northwest part of the field are more coarse grained than the shallow deposits in the southeast part of the field.

The texture difference between the two areas of the field may be the reason for the higher salinity of the ground-water samples collected from the wells along geohydrologic section $A-A^{\prime}$ compared with those along geohydrologic section $B-B^{\prime}$. The finer grained deposits in the southeast part of the field may have restricted infiltration and downward movement of water to a greater degree than in the northwest part of the field, causing greater evapoconcentration of the shallow ground water. This is consistent with the observation made by Clyde Irion (farm manager, oral commun., 1986) that the water table was within $0.6 \mathrm{~m}$ of land surface, and the soil was more saline in the southeast part of the field in the mid-1970's. From grain-size analyses, the wells were divided into coarse- or fine-grained groups according to the texture of the deposits adjacent to the well screen. Coarse-grained materials are those containing greater than 70 percent sand.

\section{HYDRAULIC CONDUCTIVITY}

Two methods were used to determine hydraulic conductivities. The method of analysis described by Hvorslev (1951) assumes a homogeneous, isotropic, spatially infinite medium; an incompressible medium and constant specific gravity of water; and wells with small screened intervals. Flow to the well screen is assumed to be spherical and isotropic. The Cooper method (Cooper and others, 1967) also assumes a homogeneous, isotropic, and spatially infinite medium, but in contrast with the first technique the medium is confined, both water and medium are assumed compressible, and the well is screened over the entire thickness of the aquifer. Flow to the well is assumed to be horizontal.

Analysis by the Hvorslev method uses regression analysis to calculate the transmissivity of the aquifer at the screened interval by the equation:

$$
T=(-1-b) / m,
$$

where

$T$ is the transmissivity,

$b$ is the $y$-intercept, (hydraulic head at time $=0$ ) and

$m$ is the slope of the regression line between hydraulic head and time.

The hydraulic conductivity was calculated by dividing the transmissivity by the length of the well screen. Data analysis using this method results in values for spherical, isotropic flows.

Values of hydraulic conductivities calculated by the Cooper method apply to water moving horizontally to and from the well. The Cooper method assumes that the length of the well screen is equal to the thickness of the aquifer.

The relation of the logs of hydraulic conductivity determined by the Hvorslev and Cooper methods for wells screened in the fine-grained and coarse-grained material are shown in figure 18. The hydraulic conductivities determined by the two methods are highly correlated; $r^{2}=0.74$ for the fine-grained wells and $r^{2}=0.87$ for the coarse-grained wells. The median horizontal hydraulic conductivity values of the coarsegrained material are 565 and $1,983 \mathrm{~m} / \mathrm{a}$ for the Hvorslev and Cooper methods, respectively. The values for the fine-grained deposits are 195 and 671 $\mathrm{m} / \mathrm{a}$, respectively. There is considerable variability in the fine-grained and coarse-grained deposits, but the medians are significantly different $(\alpha=0.05)$, as determined by the Mann-Whitney test (Hollander and Wolfe, 1973). There is a significant but weak correlation between percent sand and the log hydraulic conductivity $\left(r^{2}=0.25\right)$. Large horizontal hydraulic conductivity values in wells screened in fine-grained material probably are due to coarse-grained lenses. 

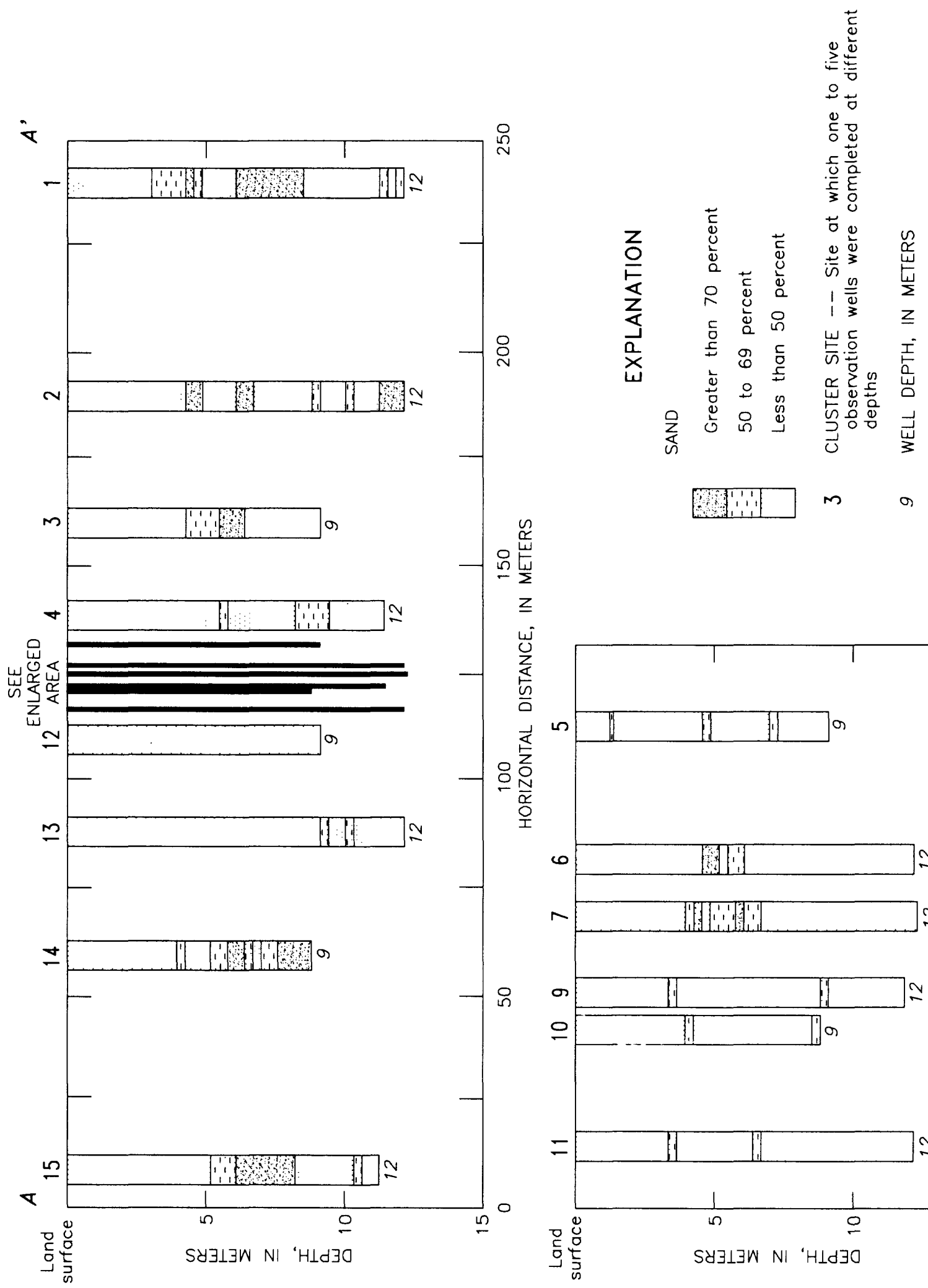

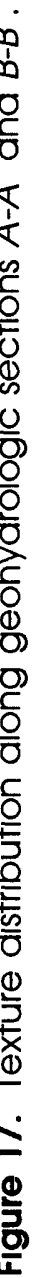




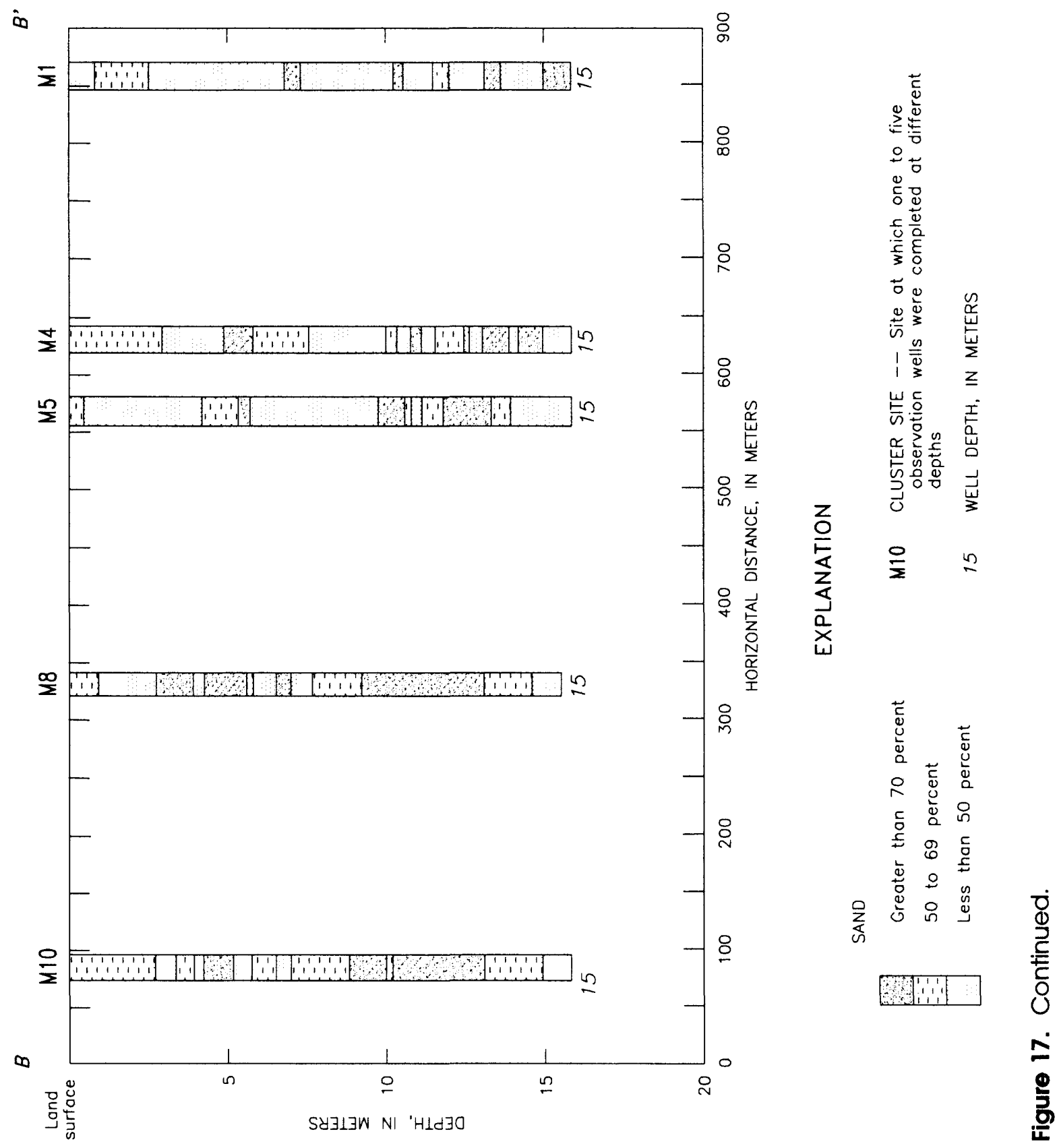




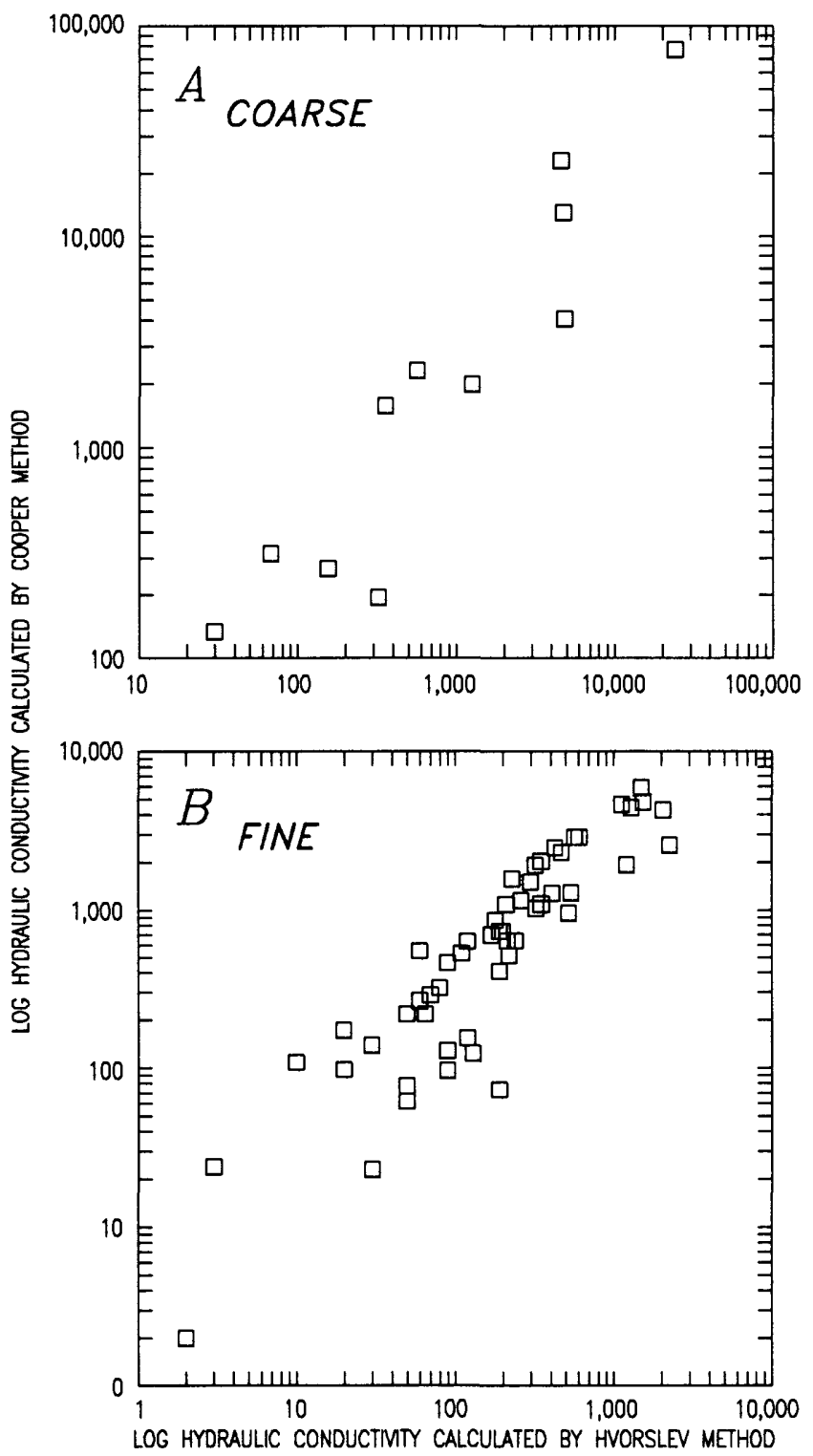

Figure 18. Relation of hydraulic conductivity determined by the methods of Hvorslev (1951) and Cooper and others (1967) in wells with screened intervals opposite coarse- and finegrained deposits.

The median horizontal hydraulic conductivity determined by the Cooper method is about 3.5 times larger than the hydraulic conductivity determined by the Hvorslev method for the coarse-grained and fine-grained wells. Using the approach described by Prudic (1982), the anisotropy of the deposits can be roughly estimated from the results of the two methods. For both fine-grained and coarse-grained materials, horizontal hydraulic conductivity is about
12 times the vertical conductivity. The method described by Prudic (1982) may not be directly applicable to the deposits in this field because of the layering demonstrated by the results of this study. Prudic applied the method to glacial till that generally showed less anisotropy. However, the analysis does provide an initial estimate of the anisotropy.

\section{DISTRIBUTION OF CHEMICAL CONSTITUENTS IN THE SOLID PHASE}

Concentrations of constituents were evaluated in the solid phase to gain information about the factors affecting the mobility and distribution of constituents, notably selenium, in the ground water and solid phase. Because of the large number of constituents and samples, principle-component analyses was used to examine interrelations among constituents. Table 1 shows the principal component scores for the solid phase chemical data. Eighty percent of the variance in the solid phase chemical data can be accounted for by four principal components. The constituents associated with these four principal components are similar to those reported by Tidball and others (1986) and will be denoted similarly. The first principal component accounts for most of the variance and is denoted as a felsic component. The elements associated with this component are those associated with alumino silicate and iron and manganese oxides, for example, iron, manganese, aluminum, copper, titanium, and others (table 1).

The second principal component is denoted as serpentinitic (Tidball and others, 1986) because of the large association with chromium, cobalt, magnesium, and nickel. The soils in this area are derived partly from a serpentine outcrop in the California Coast Ranges to the west. Samples by Tidball and others (1986) in the area of this field had large principalcomponent scores for this principal component. Principal-component scores for residual selenium and organic carbon are negative for this principal component meaning that neither of these constituents would be expected in high concentrations in a sample where the second principal component score was high.

The third principal component is denoted as a salinity principal component and it is associated with the dissolved solids. Total selenium also is highly correlated with this principal component indicating that there is some association of dissolved solids in the saturation extract and the total amount of selenium 
Table 1. Principal component scores for the solid phase chemical data

(Samples were collected during drilling at observation well sites)

\begin{tabular}{|c|c|c|c|c|}
\hline \multirow{2}{*}{ Constituent } & \multicolumn{4}{|c|}{ Principal component } \\
\hline & Felsic & $\begin{array}{c}\text { Serpen- } \\
\text { tinitic }\end{array}$ & $\begin{array}{l}\text { Salin- } \\
\text { ity }\end{array}$ & $\begin{array}{c}\text { Car- } \\
\text { bonate }\end{array}$ \\
\hline luminum & 0.963 & -0.135 & -0.057 & -0.146 \\
\hline$=0$ & .655 & -.012 & .380 & .393 \\
\hline rium & -.623 & -.455 & -.074 & .259 \\
\hline lcium & .563 & .282 & .463 & .127 \\
\hline Cerium . & .934 & -.111 & -.056 & -.102 \\
\hline aro & .280 & .596 & .291 & .501 \\
\hline Cobalt & .731 & .538 & 76 & .276 \\
\hline Copper & .948 & -.035 & .007 & -.045 \\
\hline & .987 & & -.069 & -.051 \\
\hline Lanthanum & .941 & -.127 & -.095 & -.163 \\
\hline ead & .255 & -.585 & .033 & .302 \\
\hline & .971 & & & -.078 \\
\hline in & .441 & .789 & 0 & .272 \\
\hline & .817 & .373 & -.115 & -.013 \\
\hline Neodymium & .940 & -.054 & .009 & -.130 \\
\hline • & .064 & 7 & & .452 \\
\hline PI & .806 & & & .032 \\
\hline & -.795 & -.264 & -.151 & -.238 \\
\hline Scal & .972 & .037 & -.102 & -.080 \\
\hline Total selenium & .306 & -.006 & .804 & .024 \\
\hline & & & & .271 \\
\hline $\mathrm{Re}$ & .176 & -.665 & .3 & .330 \\
\hline Sodium & -.646 & .229 & .405 & .122 \\
\hline St & .000 & .407 & .509 & -.288 \\
\hline Thorium & .897 & -.238 & .001 & -.074 \\
\hline & .978 & & & -.082 \\
\hline ium & .977 & -.066 & -.058 & -.062 \\
\hline Yttrium & .937 & & & -.067 \\
\hline & .949 & -.181 & -.022 & -.082 \\
\hline Total carbon & .448 & -.604 & .150 & .411 \\
\hline & .330 & $\because$ & .0 & .184 \\
\hline & .439 & -.126 & .351 & .622 \\
\hline Specific conductance . . & -.083 & .413 & .677 & -.133 \\
\hline $\begin{array}{l}\text { Percentage of } \\
\text { total variance }\end{array}$ & 52.0 & 14.3 & 7.8 & 5.9 \\
\hline
\end{tabular}

in the soil. The fourth principal component is denoted as a carbonate component because of the high scores for inorganic carbon. Chromium is moderately associated with this principal component.
Soluble selenium generally represents a small fraction of the total concentration of selenium in the solid phase in the unsaturated and shallow saturated zone. This is illustrated by the depth distributions of the total, soluble, and residual selenium shown in figure 19. In contrast, soluble selenium represents most of the total selenium in the saturated zone between 6 and $9 \mathrm{~m}$ where selenium concentrations in ground water are high (fig. 4). These data are consistent with the hypothesis set forth by Fujii and others (1988). They stated that most soluble selenium had been leached from the unsaturated zone during decades of irrigation.

The concentrations of selenium in the solid phase not in a soluble form (residual selenium) generally are highest in the unsaturated and shallow saturated zone and decrease with depth (fig. 19). The percentage of organic carbon in the solid phase follows a similar pattern (fig. 19) and is significantly correlated $(r=0.69, \alpha=0.01)$ with residual selenium.

The relation of the percentage of organic carbon to residual selenium is shown in figure 20 . For concentrations of residual selenium less than about

\section{EXPLANATION FOR FIGURE 19}

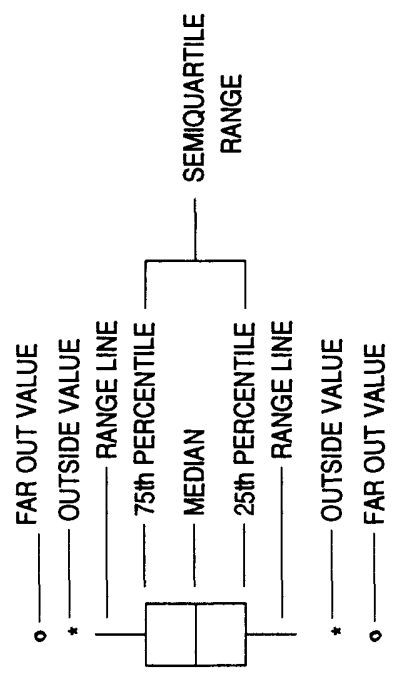

Far out values are more than 3.0 times the semiquartile range from the end of the rectangle

Outside values are between 1.5 and 3.0 times the semiquartile range from the end of the rectangle

Range lines extend a distance equal to 1.5 times the semiquartile range away from the end of the rectangle or to the limit of the data, whichever is least

6 Number of observations 

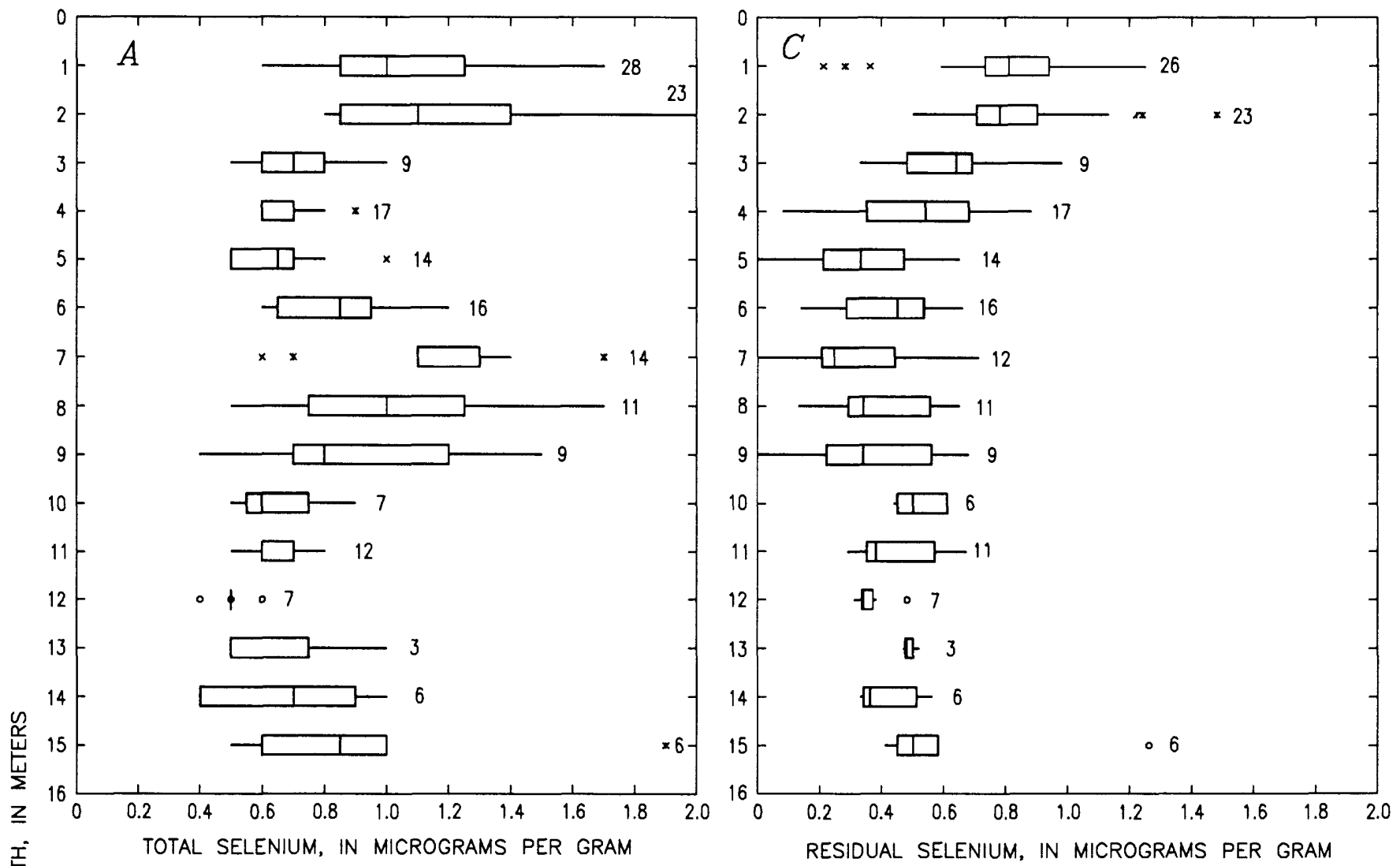

点
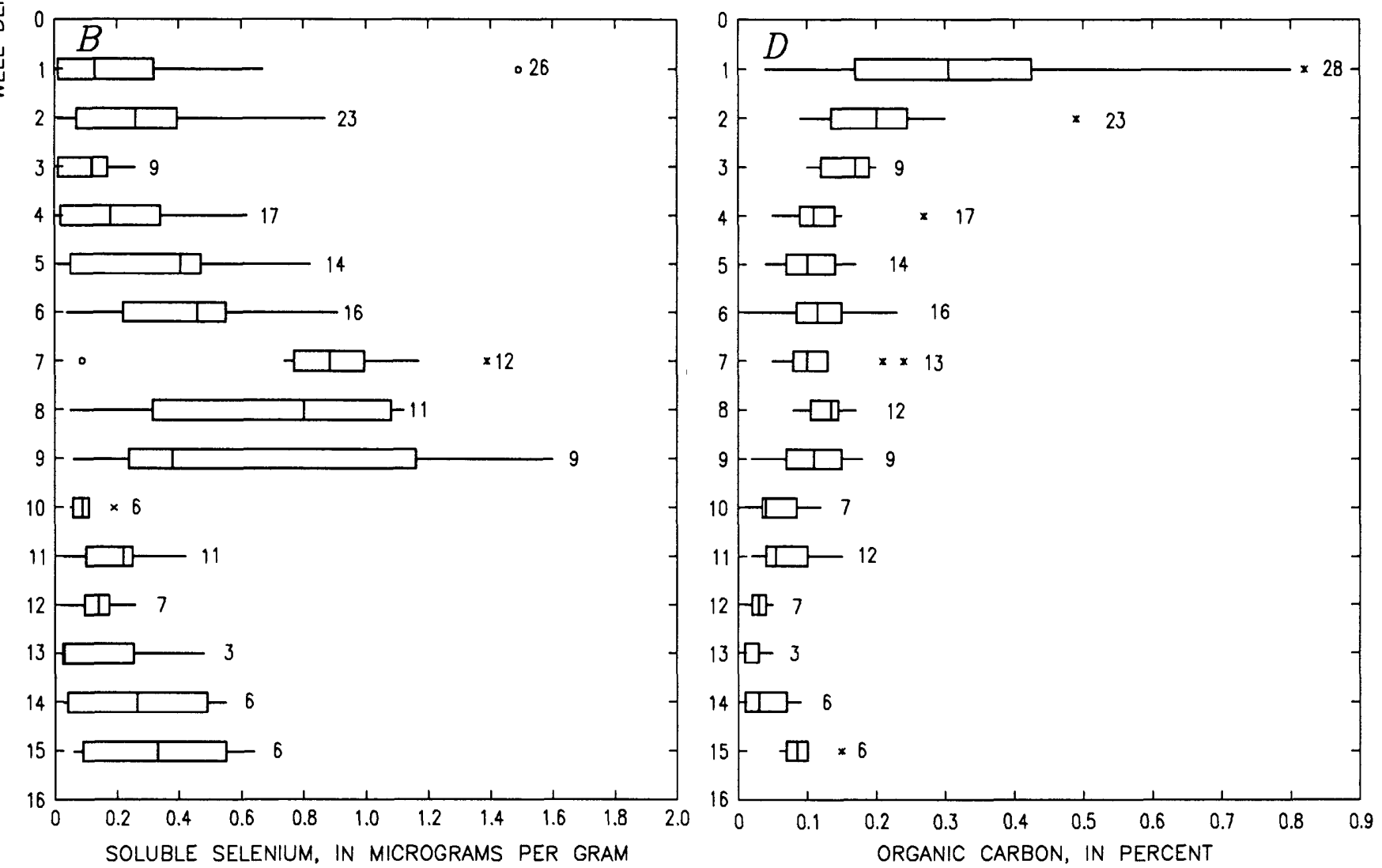

Figure 19. Concentrations of total, soluble, and residual selenium and organic carbon in the solid phase. 


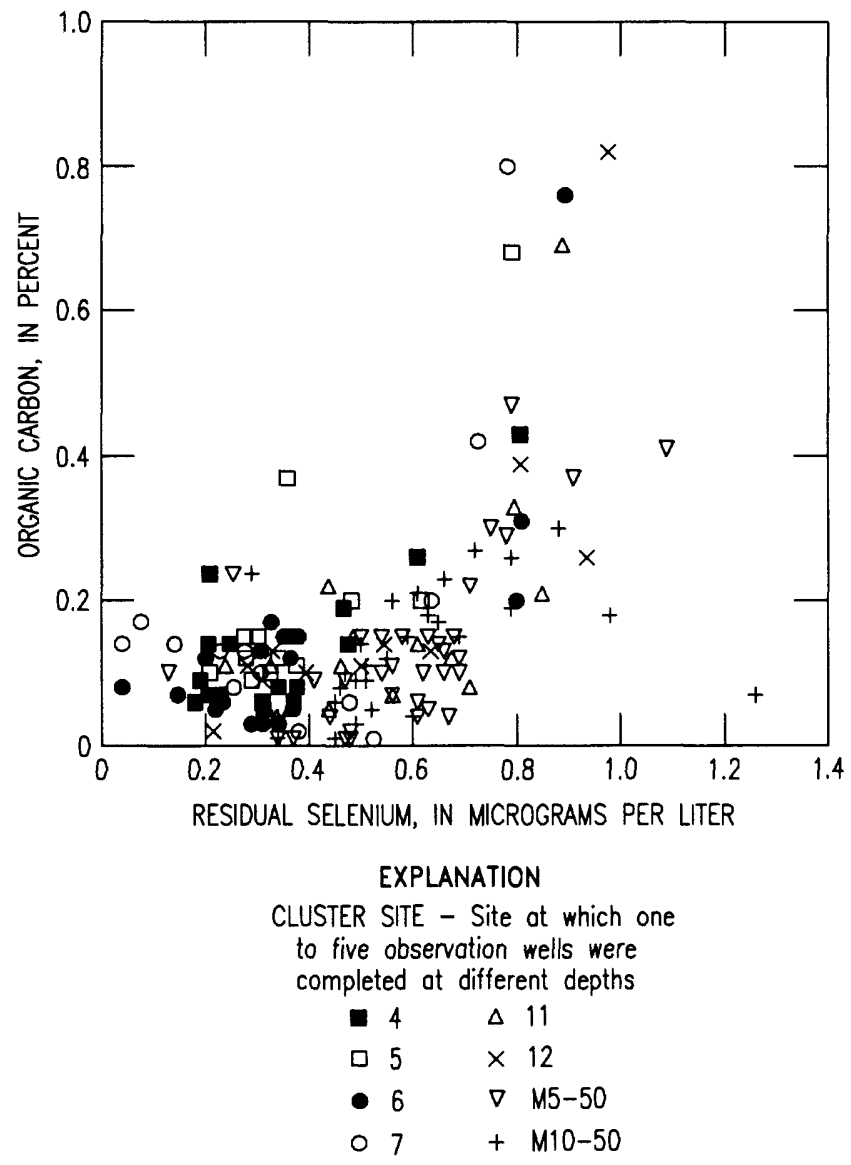

Figure 20. Relation of percentage of organic carbon to residual selenium concentrations.

$0.6 \mu \mathrm{g} / \mathrm{L}$ and organic carbon less than about 0.2 percent, residual selenium and organic carbon vary independently of one another. These low concentrations and percentages are representative of samples collected at depths greater than $3 \mathrm{~m}$ of land surface. High residual selenium concentrations are associated with organic carbon present near land surface. This is consistent with information presented by Doner and Lipton (1990). These authors presented data that indicate that a large fraction of solid phase selenium in western San Joaquin Valley soils is associated with organic matter.

Evidence suggests that soluble inorganic selenium was incorporated into organic matter over geologic time in the valley soils. Doner and others (1989) present evidence that this organic matter is being oxidized over time since the beginning of irrigation. By comparing archived soil samples collected in the 1940's and soil samples collected at the same sites in 1985, these authors found that organic carbon decreased, on the average in every soil series collected except one at the $15-\mathrm{cm}$ depth. As these soils are cultivated and irrigated, organic matter that has accumulated over geologic time apparently is solubilized and oxidized. Selenium associated with this organic matter can be mobilized as this process occurs.

\section{SUMMARY AND CONCLUSIONS}

The results of the study illustrate the processes affecting the spatial and temporal distribution of salinity, selenium, and other inorganic constituents in an artificially drained agricultural field. Evapoconcentration of shallow ground water and ground-water flow are the primary processes affecting these distributions.

The highest selenium concentrations and salinities in ground water are the result of evapotranspiration from a shallow water table. This is evidenced by the high correlation of salinity, selenium, and enrichment in deuterium and oxygen-18.

During this study, the ground water with the highest selenium concentrations was at 6 to $9 \mathrm{~m}$ below land surface. Stable-isotope and tritium data support the hypothesis that this ground water was near land surface at some time in the past and has been displaced downward by less saline ground water since at least 1970 . The ground water at depths less than $6 \mathrm{~m}$ is less saline and has lower selenium concentrations because it was near land surface after drainagesystem installation. Concentrations of other mobile constituents such as boron, lithium, and vanadium are also significantly correlated with ground-water salinity.

Analysis of samples of soils and aquifer materials provided information about the factors affecting selenium mobility. The concentration of soluble selenium in the solid phase was lowest in the unsaturated zone and shallow saturated zone, indicating that it had been leached by irrigation. The concentrations of the residual selenium in the soil and aquifer-material samples were significantly correlated with organic carbon, indicating that the mobility of selenium in the solid phase was influenced by the mobilization of organic carbon.

Analysis of hydraulic gradients provide information about directions of ground-water flow. During the irrigation season, gradients are primarily downward. 
Sand lenses influence ground-water flow by conducting ground water more rapidly than adjacent finegrained layers. This results in upward and downward flow into the sand lenses during nonirrigated periods. Regional collector drains substantially influence nearsurface ground-water flow. Drain laterals and draincollector lines influence flow to a lesser extent.

\section{REFERENCES CITED}

Allison, G.E., 1982, The relationship between ${ }^{18} \mathrm{O}$ and deuterium in water in sand columns undergoing evaporation: Journal of Hydrology, v. 55, p. 163-169.

Barnes, C.J., and Allison, G.B., 1983, The distribution of deuterium and ${ }^{18} \mathrm{O}$ in dry soils. 1. Theory: Journal of Hydrology, v. 60, p. 141-156.

Belitz, Kenneth, and Heimes, F.J., 1990, Character and evolution of the ground-water flow system in the central part of the western San Joaquin Valley, California: U.S. Geological Survey Water-Supply Paper 2348, 28 p.

Briggs, P.H., and Crock, J.G., 1986, Automated determination of total selenium in rocks, soils, and plants: U.S. Geological Survey Open-File Report 86-40, 20 p.

Bull, W.B., 1964, Geomorphology of segmented alluvial fans in western Fresno County, California: U.S. Geological Survey Professional Paper 352-E., p. 89-129.

Bull, W.B., and Miller, R.E., 1975, Land subsidence due to ground-water withdrawal in the Los Banos-Kettleman City area, California. Part 1. Changes in the hydrologic environment conducive to subsidence: U.S. Geological Survey Professional Paper 437-E, $71 \mathrm{p}$.

Cooper, H.H., Jr., Bredehoeft, J.D., and Papadopulos, I.S., 1967, Response of a finite-diameter well to an instantaneous charge of water: Water Resources Research, v. 3, no. 1, p. 263-269.

Craig, H., 1961, Isotopic variation in meteoric waters: Science, v. 133, p. 1833.

Davis, G.H., and Coplen, T.B., 1987, Stable isotopic composition of groundwater of central California as an indicator of mid-pleistocene tectonic evolution: Isotope Techniques in Water Resources Development, International Atomic Energy Agency, Proceedings, p. 225-239.

Davis, G.H., and Poland, J.F., 1957, Ground-water conditions in the Mendota-Huron area, Fresno and Kings Counties, California: U.S. Geological Survey WaterSupply Paper 1360-G, p. 409-588.

Deverel, S.J., and Fujii, Roger, 1988, Processes affecting the distribution of selenium in shallow groundwater of agricultural areas, western San Joaquin Valley, California: Water Resources Research, v. 24, no. 4, p. 516-524.

Deverel, S.J., and Gallanthine, S.K., 1989, Relation of salinity and selenium in shallow groundwater to hydrologic and geochemical processes, western San Joaquin Valley, California: Journal of Hydrology, v. 109 , p. $125-149$.
Deverel, S.J., and Millard, S.P., 1988, Distribution and mobility of selenium and other trace elements in shallow groundwater of the western San Joaquin Valley, California: Environmental Science and Technology, v. 22 , no. 6, p. 697-702.

Doner, H.E., Amundson, R.G., and Lilieholm, B., 1989, A comparison of Se and As concentrations in soils of the western San Joaquin Valley, California, 1946-1985: Arid Soil Research Rehabilitation, v. 3, p. 315-325.

Doner, H.E., and Lipton, D.S., 1990, Soil organic matter interactions with selenium in K.K. Tanji, and others (eds.), 1989-90 Technical Progress Report, UC Salinity/ Drainage Task Force: Davis, University of California, Division of Agriculture and Natural Resources, $156 \mathrm{p}$.

Epstein, S., and Mayeda, T., 1953, Variation of the O-18 content of waters from natural sources: Geochimica et Cosmochimica Acta, v. 4, p. 213-224.

Fishman, M.J., and Friedman, L.C., eds., 1985, Methods for determination of inorganic substances in water and fluvial sediments: U.S. Geological Survey Techniques of Water-Resources Investigations, Book 5, Chapter A1, $709 \mathrm{p}$.

Fio, J.L., and Deverel, S.J., 1990, Ground-water flow and solute movement to drain laterals, western San Joaquin Valley, California. II. Quantitative hydrologic assessment: U.S. Geological Survey Open-File Report 90-137, $15 \mathrm{p}$.

Fontes, J.C., and Gonfiantini, R., 1967, Isotopic composition of two Saharan basins: Earth and Planetary Science Letters, v. 3, p. 258-266.

Freeze, R.A., and Cherry, J.A., 1979, Groundwater: Englewood Cliffs, New Jersey, Prentice-Hall, 604 p.

Fujii, Roger, Deverel, S.J., and Hatfield, D.B., 1988, Distribution of selenium in soils of agricultural fields, western San Joaquin Valley, California: Soil Science Society of America Journal, v. 52, no. 5, p. 1274-1283.

Gat, J.R., 1971, Comments on the stable isotope method in regional groundwater investigations: Water Resources Research, v. 7, no. 4, p. 980-993.

Guy, H.P., 1969, Laboratory theory and methods for sediment analysis: U.S Geological Survey Techniques of Water-Resources Investigations, Book 5, Chapter $\mathrm{C} 1$, $58 \mathrm{p}$.

Harradine, F.F., 1950, Soils of western Fresno County: Berkeley, University of California Press, $86 \mathrm{p}$.

Hem, J.D., 1985, Study and interpretation of the chemical characteristics of natural water: U.S. Geological Survey Water-Supply Paper 2254, 264 p.

Hollander, M., and Wolfe, D.A., 1973, Nonparametric statistical methods: New York, John Wiley, 503 p.

Hvorslev, J.M., 1951, Time lag and soil permeability in ground-water observations: U.S. Army Corps of Engineers, Waterways Express Station, Vicksburg, Mississippi, Bulletin 36, 50 p.

International Atomic Energy Agency, 1976, Proceedings and technique critique of tritium enrichment by electrolysis: International Atomic Energy Agency Technical Note, No. 19. 
International Atomic Energy Agency, 1981, Stable isotope hydrology: deuterium and oxygen-18 in the water cycle: International Atomic Energy Agency Technical Reports, Series No. 210, 335 p.

Johnson, R.A., and Wichern, D.W., 1982, Applied multivariate statistical analysis: Englewood Cliffs, New Jersey, Prentice-Hall.

Jury, W.A., 1975a, Solute travel-time estimates for tile drained fields. I. Theory: Soil Science Society of America, v. 39, p. 1020-1024.

$1975 \mathrm{~b}$, Solute travel-time estimates for tile drained fields. II. Experimental: Soil Science Society of America, v. 39, p. 1024-1028.

Kendall, Carol, and Coplen, T.B., 1985, Multisample conversion of water to hydrogen by zinc for stable isotope determination: Analytical Chemistry, v. 57, no. 7, p. 1437-1440.

Laudon, Julie, and Belitz, Kenneth, 1991, Texture and depositional history of late Pleistocene-Holocene alluvium in the central part of the western San Joaquin Valley, California: Bulletin of the Association of Engineering Geologists, v. 28, no. 1, p. 73-88.

Luthin, J.N., Fernandez, P., Maslov, B., Woerner, J., and Robinson, F., 1969, Displacement front under ponded leaching: American Society of Civil Engineers, Journal of the Irrigation Drainage Division, v. 95, p. 117-125.

Mansell, R.S., McKenna, P.J., and Hall, M.E., 1985, Solute discharge during steady water drainage from a sand tank: Soil Science Society of America, v. 49, p. 556-562.

Mendenhall, W.C., Dole, R.B., and Stabler, Herman, 1916, Ground water in San Joaquin Valley, California: U.S. Geological Survey Water-Supply Paper 398, 310 p.

Miller, R.E., Green, J.H., and Davis, G.H., 1971, Geology of the compacting deposits in the Los Banos-Kettleman City subsidence area, California: U.S. Geological Survey Professional Paper 497-E, 46 p.

Ohlendorf, H.M., Hothem, R.L., Bunck, C.M., Aldrich, T.W., and Moore, J.F., 1986, Relationships between selenium concentration and avian reproduction: North American Wildlife and Natural Resources Conference, 51st, Reno, Nevada, Transactions, 1986, p. 330-442.
Ortiz, J., and Luthin, J.N., 1970, Movement of salts in ponded anisotropic soils: American Society of Civil Engineers, Journal of the Irrigation Drainage Division, v. 96, p. $256-264$.

Pillsbury, A.F., Johnston, W.R., Ittihadieh, F., and Daum, R.M., 1965, Salinity of tile drainage effluent: Water Resources Research, v. 1, no. 4, p. 531-535.

Plummer, L.N., Jones, B.F., and Truesdell, A.H., 1976, WATEQF-A FORTRAN IV version of WATEQ, a computer program for calculating chemical equilibrium of natural waters: U.S. Geological Survey WaterResources Investigations Report 76-13, 66 p.

Prudic, D.E., 1982, Hydraulic conductivity of a finegrained till, Cattaraugus County, New York: Ground Water, v. 20, no. 2, p. 194-204.

Raats, P.A.C., 1978, Convective transport of solutes by steady flows, II, Specific flow problems: Agricultural Water Management, v. 1, p. 219-232.

San Joaquin Valley Drainage Program, 1990, A management plan for agricultural subsurface drainage and related problems on the westside San Joaquin Valley, Final Report of the San Joaquin Valley Drainage Program, $183 \mathrm{p}$.

Thornton, Iain, ed., 1983, Applied environmental geochemistry: New York, Academic Press, 501 p.

Tidball, R.R., Grundy, W.D., and Sawatzky, D.L., 1986, Kriging techniques applied to element distribution in soils of the San Joaquin Valley, California: HAZTECH International Conference, Denver, Colorado, August 13-15, 1986, Proceedings, p. 992-1009.

U.S. Bureau of Reclamation, 1984, Kesterson Reservoir and waterfowl: Information Bulletin 1, $10 \mathrm{p}$.

Wershaw, R.L., Fishman, M.J., Grabbe, R.R. and Lowe, L.E., eds., 1987, Methods for the determination of organic substances in water and fluvial sediments: U.S. Geological Survey Techniques of Water-Resources Investigations, Book 5, Chapter $\mathrm{A} 3,80 \mathrm{p}$.

Wood, W.W., 1981, Guidelines for collection and field analysis of ground-water samples for selected unstable constituents: U.S. Geological Survey Techniques of Water-Resources Investigations, Book 1, Chapter D2, $24 \mathrm{p}$.

Zat, I., and Gat, J.R., 1975, Saline waters and residual brines in the Shiraz-Sarvistan Basin, Iran: Chemical Geology, v. 16, p. 179-188. 
Table 2. Site, well depth, and constituents determined for water samples collected in the drained agricultural field

[Cluster site: Site at which one to five observation wells were installed at different depths. Site identification No.: Unique number for each well based on the latitude and longitude of the site. First six digits are latitude, next seven digits are longitude, and final two digits are a sequence number to uniquely identify each well. Well depth: Depth, in meters below land surface, of each observation well completed at cluster site. Type of analyses: xx, data available; --, no data]

\begin{tabular}{|c|c|c|c|c|c|c|}
\hline \multirow{2}{*}{$\begin{array}{l}\text { Cluster } \\
\text { site }\end{array}$} & \multirow{2}{*}{$\begin{array}{c}\text { Site } \\
\text { identification } \\
\text { No. }\end{array}$} & \multirow[b]{2}{*}{ Well depth } & \multicolumn{4}{|c|}{ Type of analyses } \\
\hline & & & $\begin{array}{c}\text { Major } \\
\text { ions }\end{array}$ & $\begin{array}{c}\text { Trace } \\
\text { elements }\end{array}$ & $\begin{array}{c}\text { Stable } \\
\text { isotopes }\end{array}$ & Tritium \\
\hline EW1 & 363906120243601 & $\begin{array}{l}3 \\
4 \\
4.5 \\
6\end{array}$ & $\begin{array}{l}-- \\
\mathbf{x x} \\
-- \\
--\end{array}$ & $\begin{array}{l}-- \\
\mathbf{x x} \\
-- \\
--\end{array}$ & $\begin{array}{l}-- \\
\mathbf{x x} \\
-- \\
--\end{array}$ & $\begin{array}{l}-- \\
\mathbf{x x} \\
-- \\
--\end{array}$ \\
\hline EW2 & 363906120243602 & $\begin{array}{l}3 \\
4 \\
4.5 \\
6\end{array}$ & $\begin{array}{l}-- \\
\mathbf{x x} \\
-- \\
--\end{array}$ & $\begin{array}{l}-- \\
\mathbf{x x} \\
-- \\
--\end{array}$ & $\begin{array}{l}-- \\
\mathbf{x x} \\
-- \\
--\end{array}$ & $\begin{array}{l}-- \\
-- \\
-- \\
--\end{array}$ \\
\hline EW3 & 363906120243603 & $\begin{array}{l}3 \\
4 \\
4.5 \\
6\end{array}$ & $\begin{array}{l}-- \\
\mathrm{xx} \\
-- \\
--\end{array}$ & $\begin{array}{l}-- \\
\mathbf{x x} \\
-- \\
--\end{array}$ & $\begin{array}{l}-- \\
\mathbf{x x} \\
-- \\
--\end{array}$ & $\begin{array}{l}-- \\
-- \\
-- \\
--\end{array}$ \\
\hline EW4 & 363906120243604 & 4 & $\mathbf{x x}$ & $\mathrm{xx}$ & -- & $\mathrm{xx}$ \\
\hline EW5 & 363906120243605 & 4 & $\mathbf{x x}$ & $\mathbf{x x}$ & -- & $\mathbf{x x}$ \\
\hline EW6 & 363906120243606 & 4 & $\mathbf{x x}$ & $\mathbf{x x}$ & -- & $\mathbf{x x}$ \\
\hline MA & 363915120242002 & 15 & $\mathbf{x x}$ & $x x$ & $\mathbf{x x}$ & $\mathbf{x x}$ \\
\hline MB & 363902120242559 & 15 & $\mathbf{x x}$ & $\mathrm{xx}$ & $\mathbf{x x}$ & $\mathbf{x x}$ \\
\hline MBS & 363902120242561 & $\begin{array}{l}4.5 \\
8.5 \\
9\end{array}$ & $\begin{array}{l}-- \\
\mathbf{x x} \\
--\end{array}$ & $\begin{array}{l}-- \\
\mathrm{xx} \\
--\end{array}$ & $\begin{array}{l}-- \\
\mathrm{xx} \\
--\end{array}$ & $\begin{array}{l}-- \\
\mathrm{xx} \\
--\end{array}$ \\
\hline MCS & 363902120242564 & $\begin{array}{l}4.5 \\
8.5 \\
9\end{array}$ & $\begin{array}{l}-- \\
\mathbf{x x} \\
--\end{array}$ & $\begin{array}{l}-- \\
\mathbf{x x} \\
--\end{array}$ & $\begin{array}{l}-- \\
\mathbf{x x} \\
--\end{array}$ & $\begin{array}{l}-- \\
\mathbf{x x} \\
--\end{array}$ \\
\hline MDS & 363902120242567 & $\begin{array}{l}4.5 \\
8 \\
8.5\end{array}$ & $\begin{array}{l}-\bar{x} \\
\mathbf{x x}\end{array}$ & $\begin{array}{l}-- \\
\mathbf{x x} \\
--\end{array}$ & $\begin{array}{l}-- \\
\mathbf{x x} \\
--\end{array}$ & $\begin{array}{l}-- \\
\mathbf{x x} \\
--\end{array}$ \\
\hline MF & $\begin{array}{l}363902120242571 \\
363902120242570 \\
363902120242569\end{array}$ & $\begin{array}{l}3.5 \\
6 \\
9\end{array}$ & $\begin{array}{l}\mathbf{x x} \\
\mathbf{x x} \\
\mathbf{x x}\end{array}$ & $\begin{array}{l}\mathbf{x x} \\
\mathbf{x x} \\
\mathbf{x x}\end{array}$ & $\begin{array}{l}\mathbf{x x} \\
\mathbf{x x} \\
\mathbf{x x}\end{array}$ & $\begin{array}{l}\mathbf{x x} \\
\mathbf{x x} \\
\mathbf{x x}\end{array}$ \\
\hline M1 & $\begin{array}{l}363906120244618 \\
363906120244617 \\
363906120244616 \\
363906120244615 \\
363906120244614\end{array}$ & $\begin{array}{r}3 \\
6 \\
9 \\
12 \\
15\end{array}$ & $\begin{array}{l}\mathbf{x x} \\
\mathbf{x x} \\
\mathbf{x x} \\
\mathbf{x x} \\
\mathbf{x x}\end{array}$ & $\begin{array}{l}\mathbf{x x} \\
\mathbf{x x} \\
\mathbf{x x} \\
\mathbf{x x} \\
\mathbf{x x}\end{array}$ & $\begin{array}{l}\mathbf{x x} \\
\mathbf{x x} \\
\mathbf{x x} \\
\mathbf{x x} \\
\mathbf{x x}\end{array}$ & $\begin{array}{l}\mathbf{x x} \\
\mathbf{x x} \\
\mathbf{x x} \\
\mathbf{x x} \\
--\end{array}$ \\
\hline M4 & $\begin{array}{l}363906120244621 \\
363906120244620 \\
363906120244619\end{array}$ & $\begin{array}{r}6 \\
9 \\
15\end{array}$ & $\begin{array}{l}\mathbf{x x} \\
\mathrm{xx} \\
\mathrm{xx}\end{array}$ & $\begin{array}{l}\mathrm{xx} \\
\mathrm{xx} \\
\mathrm{xx}\end{array}$ & $\begin{array}{l}\mathbf{x x} \\
\mathbf{x x} \\
\mathbf{x x}\end{array}$ & $\begin{array}{l}\mathbf{x x} \\
\mathbf{x x} \\
\mathbf{x x}\end{array}$ \\
\hline
\end{tabular}


Table 2. Site, well depth, and constituents determined for water samples collected in the drained agricultural field--Continued

\begin{tabular}{|c|c|c|c|c|c|c|}
\hline \multirow{2}{*}{$\begin{array}{l}\text { Cluster } \\
\text { site }\end{array}$} & \multirow{2}{*}{$\begin{array}{c}\text { Site } \\
\text { identification } \\
\text { No. }\end{array}$} & \multirow[b]{2}{*}{ Well depth } & \multicolumn{4}{|c|}{ Type of analyses } \\
\hline & & & $\begin{array}{c}\text { Major } \\
\text { ions }\end{array}$ & $\begin{array}{c}\text { Trace } \\
\text { elements }\end{array}$ & $\begin{array}{c}\text { Stable } \\
\text { isotopes }\end{array}$ & Tritium \\
\hline \multirow[t]{5}{*}{ M5 } & 363906120244626 & 3 & -- & -- & -. & -- \\
\hline & 363906120244625 & 6 & $\mathbf{x x}$ & $\mathrm{xx}$ & $\mathbf{x x}$ & $\mathrm{xx}$ \\
\hline & 363906120244624 & 9 & $\mathbf{x x}$ & $\mathrm{xx}$ & $\mathbf{x x}$ & $\mathrm{xx}$ \\
\hline & 363906120244623 & 12 & $\mathbf{x x}$ & $\mathrm{xx}$ & $\mathbf{x x}$ & $\mathrm{xx}$ \\
\hline & 363906120244622 & 15 & $x x$ & $x x$ & $x x$ & $\mathbf{x x}$ \\
\hline \multirow[t]{4}{*}{ M8 } & 363906120244630 & 3 & $\mathrm{xx}$ & $x x$ & $x x$ & $\mathrm{xx}$ \\
\hline & 363906120244629 & 6 & $x x$ & $\mathrm{xx}$ & $\mathbf{x x}$ & $\mathrm{xx}$ \\
\hline & 363906120244628 & 12 & $\mathrm{xx}$ & $x x$ & $\mathbf{x x}$ & $x x$ \\
\hline & 363906120244627 & 15 & $\mathbf{x x}$ & $\mathbf{x x}$ & $\mathrm{xx}$ & $x x$ \\
\hline \multirow[t]{4}{*}{ M10 } & 363906120244634 & 3 & $\mathrm{xx}$ & $\mathrm{xx}$ & $\mathbf{x x}$ & $\mathrm{xx}$ \\
\hline & 363906120244633 & 6 & $\mathrm{xx}$ & $x x$ & $\mathrm{xx}$ & $\mathrm{xx}$ \\
\hline & 363906120244632 & 12 & $x x$ & $x x$ & $\mathbf{x x}$ & $x x$ \\
\hline & 363906120244631 & 15 & $x x$ & $\mathrm{xx}$ & $\mathbf{x x}$ & $\mathrm{xx}$ \\
\hline \multirow[t]{5}{*}{ NW1 } & 363906120244601 & 3 & -- & -- & -- & -- \\
\hline & & 4 & $x x$ & $\mathrm{xx}$ & $\mathbf{x x}$ & -- \\
\hline & & 4.5 & -- & -- & -- & -- \\
\hline & & 6 & -- & -- & -- & -- \\
\hline & & 9 & -- & -- & -- & -- \\
\hline \multirow[t]{4}{*}{ NW2 } & -- & 3 & -- & -- & -- & -- \\
\hline & & 4.5 & -- & -- & -- & -- \\
\hline & & 6 & -- & -- & -- & -- \\
\hline & & 9 & -- & -- & -- & -- \\
\hline \multirow[t]{3}{*}{ NW3 } & -- & 3 & -- & -- & -- & -- \\
\hline & & 4.5 & -- & -- & -- & -- \\
\hline & & 6 & -- & -- & -- & - \\
\hline \multirow[t]{5}{*}{ NW4 } & 363906120244604 & 3 & -- & -- & -- & -- \\
\hline & & 4 & $\mathbf{x x}$ & $\mathrm{xx}$ & $\mathrm{xx}$ & -- \\
\hline & & 4.5 & -- & -- & -- & -- \\
\hline & & 6 & -- & -- & -- & -- \\
\hline & & 9 & -- & -- & -- & -- \\
\hline \multirow[t]{3}{*}{ NW5 } & -- & 3 & -- & -- & -- & -- \\
\hline & & 4.5 & -- & -- & -- & -- \\
\hline & & 6 & -- & -- & -- & -- \\
\hline \multirow[t]{4}{*}{ NW6 } & -- & 3 & -- & -- & -- & -- \\
\hline & & 4.5 & -- & -- & -- & -- \\
\hline & & 6 & -- & -- & -- & -- \\
\hline & & 9 & -- & -- & -- & -- \\
\hline \multirow[t]{5}{*}{ NW7 } & 363906120244607 & 3 & -- & -- & -- & -- \\
\hline & & 4 & $\mathrm{xx}$ & $\mathrm{xx}$ & $\mathrm{xx}$ & -- \\
\hline & & 4.5 & -- & -- & -- & -- \\
\hline & & 6 & -- & -- & -- & -- \\
\hline & & 9 & -- & -- & -- & -- \\
\hline
\end{tabular}


Table 2. Site, well depth, and constituents determined for water samples collected in the drained agricultural field--Continued

\begin{tabular}{|c|c|c|c|c|c|c|}
\hline \multirow{2}{*}{$\begin{array}{l}\text { Cluster } \\
\text { site }\end{array}$} & \multirow{2}{*}{$\begin{array}{c}\text { Site } \\
\text { identification } \\
\text { No. }\end{array}$} & \multirow[b]{2}{*}{ Well depth } & \multicolumn{4}{|c|}{ Type of analyses } \\
\hline & & & $\begin{array}{l}\text { Major } \\
\text { ions }\end{array}$ & $\begin{array}{c}\text { Trace } \\
\text { elements }\end{array}$ & $\begin{array}{c}\text { Stable } \\
\text { isotopes }\end{array}$ & Tritium \\
\hline \multirow[t]{4}{*}{ NW8 } & -- & 3 & -- & -- & -- & -- \\
\hline & & 4.5 & -- & -- & -- & -- \\
\hline & & 6 & -- & -- & -- & -- \\
\hline & & 9 & -- & -- & -- & -- \\
\hline \multirow[t]{3}{*}{ NW9 } & -- & 3 & -- & -- & -- & -- \\
\hline & & 4.5 & -- & -- & -- & -- \\
\hline & & 6 & -- & $-\cdot$ & -- & -- \\
\hline \multirow[t]{5}{*}{ NW10 } & 363906120244610 & 3 & -- & -- & -- & -- \\
\hline & & 4 & $\mathrm{xx}$ & $\mathbf{x x}$ & $\mathrm{xx}$ & $\mathrm{xx}$ \\
\hline & & 4.5 & -- & -- & -- & -- \\
\hline & & 6 & -- & -- & -- & -- \\
\hline & & 9 & -- & -- & -- & -- \\
\hline \multirow{3}{*}{ NW11 } & -- & 3 & -- & -- & -- & -- \\
\hline & & 4.5 & -- & -- & -- & -- \\
\hline & & 6 & -- & -- & $-\cdot$ & -- \\
\hline \multirow[t]{4}{*}{ NW12 } & -- & 3 & -- & -- & -- & -- \\
\hline & & 4.5 & -- & -- & -- & -- \\
\hline & & 6 & -- & -- & -- & -- \\
\hline & & 9 & -- & -- & -- & -- \\
\hline \multirow[t]{5}{*}{ NW13 } & 363906120244613 & 3 & -- & -- & -- & -- \\
\hline & & 4 & $\mathrm{xx}$ & $\mathrm{xx}$ & $\mathrm{xx}$ & -- \\
\hline & & 4.5 & -- & -- & -- & -- \\
\hline & & 6 & -- & -- & -- & -- \\
\hline & & 9 & -- & -- & -- & -- \\
\hline \multirow[t]{5}{*}{ SE1 } & 363902120242501 & 3 & -- & -- & -- & -- \\
\hline & & 4 & $\mathrm{xx}$ & $\mathbf{x x}$ & $\mathrm{xx}$ & $\mathrm{xx}$ \\
\hline & & 4.5 & -- & -- & -- & -- \\
\hline & & 6 & -- & -- & -- & -- \\
\hline & & 9 & -- & -- & -- & -- \\
\hline \multirow[t]{3}{*}{ SE2 } & -- & 3 & -- & -- & -- & -- \\
\hline & & 4.5 & -- & -- & -- & -- \\
\hline & & 6 & -- & -- & -- & -- \\
\hline \multirow[t]{3}{*}{ SE3 } & -- & 3 & -- & -- & -- & -- \\
\hline & & 4.5 & -- & -- & -- & -- \\
\hline & & 6 & -- & -- & -- & -- \\
\hline \multirow[t]{5}{*}{ SE4 } & 363902120242504 & 3 & -- & -- & -- & -- \\
\hline & & 4 & $\mathbf{x x}$ & $\mathrm{xx}$ & $\mathbf{x x}$ & $\mathrm{xx}$ \\
\hline & & 4.5 & -- & -- & -- & -- \\
\hline & & 6 & -- & -- & -- & -- \\
\hline & & 9 & -- & -- & -- & -- \\
\hline \multirow[t]{3}{*}{ SE5 } & -- & 3 & -- & -- & -- & -- \\
\hline & & 4.5 & -- & -- & -- & -- \\
\hline & & 6 & -- & -- & -- & -- \\
\hline
\end{tabular}


Table 2. Site, well depth, and constituents determined for water samples collected in the drained agricultural field--Continued

\begin{tabular}{|c|c|c|c|c|c|c|}
\hline \multirow{2}{*}{$\begin{array}{l}\text { Cluster } \\
\text { site }\end{array}$} & \multirow{2}{*}{$\begin{array}{c}\text { Site } \\
\text { identification } \\
\text { No. }\end{array}$} & \multirow[b]{2}{*}{ Well depth } & \multicolumn{4}{|c|}{ Type of analyses } \\
\hline & & & $\begin{array}{l}\text { Major } \\
\text { ions }\end{array}$ & $\begin{array}{c}\text { Trace } \\
\text { elements }\end{array}$ & $\begin{array}{c}\text { Stable } \\
\text { isotopes }\end{array}$ & Tritium \\
\hline SE6 & -- & $\begin{array}{l}3 \\
4.5 \\
6 \\
9\end{array}$ & $\begin{array}{l}-- \\
-- \\
-- \\
--\end{array}$ & $\begin{array}{l}-- \\
-- \\
-- \\
--\end{array}$ & $\begin{array}{l}-- \\
-- \\
-- \\
--\end{array}$ & $\begin{array}{l}-- \\
-- \\
-- \\
--\end{array}$ \\
\hline SE7 & 363902120242507 & $\begin{array}{l}3 \\
4 \\
4.5 \\
6 \\
9\end{array}$ & $\begin{array}{l}-- \\
\mathbf{x x} \\
-- \\
-- \\
--\end{array}$ & $\begin{array}{l}-- \\
\mathbf{x x} \\
-- \\
-- \\
--\end{array}$ & $\begin{array}{l}-- \\
\text { XX } \\
-- \\
-- \\
--\end{array}$ & $\begin{array}{l}-- \\
\text { Xx } \\
-- \\
-- \\
--\end{array}$ \\
\hline SE8 & -- & $\begin{array}{l}3 \\
4.5 \\
6 \\
8.5\end{array}$ & $\begin{array}{l}-- \\
-- \\
-- \\
--\end{array}$ & $\begin{array}{l}-- \\
-- \\
-- \\
--\end{array}$ & $\begin{array}{l}-- \\
-- \\
-- \\
--\end{array}$ & $\begin{array}{l}-- \\
-- \\
-- \\
--\end{array}$ \\
\hline SE9 & -- & $\begin{array}{l}3 \\
4.5 \\
6\end{array}$ & $\begin{array}{l}-- \\
-- \\
--\end{array}$ & $\begin{array}{l}-- \\
-- \\
--\end{array}$ & $\begin{array}{l}-- \\
-- \\
--\end{array}$ & $\begin{array}{l}-- \\
-- \\
--\end{array}$ \\
\hline SE10 & 363902120242510 & $\begin{array}{l}3 \\
4 \\
4.5 \\
6 \\
9\end{array}$ & $\begin{array}{l}-- \\
\mathbf{x x} \\
-- \\
-- \\
--\end{array}$ & $\begin{array}{l}-- \\
\mathbf{x x} \\
-- \\
-- \\
--\end{array}$ & $\begin{array}{l}-- \\
\mathbf{x x} \\
-- \\
-- \\
--\end{array}$ & $\begin{array}{l}-- \\
\mathbf{x x} \\
-- \\
-- \\
--\end{array}$ \\
\hline SE11 & -- & $\begin{array}{l}3 \\
4.5 \\
6\end{array}$ & $\begin{array}{l}-- \\
-- \\
--\end{array}$ & $\begin{array}{l}-- \\
-- \\
--\end{array}$ & $\begin{array}{l}-- \\
-- \\
--\end{array}$ & $\begin{array}{l}-- \\
-- \\
--\end{array}$ \\
\hline SE12 & -- & $\begin{array}{l}3 \\
4.5 \\
6 \\
9\end{array}$ & $\begin{array}{l}-- \\
-- \\
-- \\
--\end{array}$ & $\begin{array}{l}-- \\
-- \\
-- \\
--\end{array}$ & $\begin{array}{l}-- \\
-- \\
-- \\
--\end{array}$ & $\begin{array}{l}-- \\
-- \\
-- \\
--\end{array}$ \\
\hline SE13 & 363902120242513 & $\begin{array}{l}3 \\
4 \\
4.5 \\
6 \\
9\end{array}$ & $\begin{array}{l}-- \\
\mathbf{x x} \\
-- \\
-- \\
--\end{array}$ & $\begin{array}{l}-- \\
\mathbf{x x} \\
-- \\
-- \\
--\end{array}$ & $\begin{array}{l}-- \\
\mathbf{x x} \\
-- \\
-- \\
--\end{array}$ & $\begin{array}{l}-- \\
-- \\
-- \\
-- \\
--\end{array}$ \\
\hline 1 & $\begin{array}{l}363902120242514 \\
363902120242515 \\
363902120242516 \\
363902120242517\end{array}$ & $\begin{array}{r}3 \\
6 \\
9 \\
12\end{array}$ & $\begin{array}{l}\mathbf{x x} \\
\mathbf{x x} \\
\mathbf{x x} \\
\mathbf{x x}\end{array}$ & $\begin{array}{l}\mathbf{x x} \\
\mathbf{x x} \\
\mathbf{x x} \\
\mathbf{x x}\end{array}$ & $\begin{array}{l}\mathbf{x x} \\
\mathbf{x x} \\
\mathbf{x x} \\
\mathbf{x x}\end{array}$ & $\begin{array}{l}x x \\
x x \\
x x \\
x x\end{array}$ \\
\hline $1 \mathrm{~A}$ & -- & 3 & -- & -- & -- & -- \\
\hline 1B & -- & 3 & -- & -- & -- & -- \\
\hline 2 & $\begin{array}{l}363902120242518 \\
363902120242519 \\
363902120242520\end{array}$ & $\begin{array}{r}3 \\
6 \\
12\end{array}$ & $\begin{array}{l}\mathbf{x x} \\
-- \\
\mathrm{xx}\end{array}$ & $\begin{array}{l}\mathbf{x x} \\
-- \\
\mathrm{xx}\end{array}$ & $\begin{array}{l}\mathbf{x x} \\
-- \\
\mathbf{x x}\end{array}$ & $\begin{array}{l}\mathbf{x x} \\
-- \\
\mathbf{x x}\end{array}$ \\
\hline
\end{tabular}


Table 2. Site, well depth, and constituents determined for water samples collected in the drained agricultural field--Continued

\begin{tabular}{|c|c|c|c|c|c|c|}
\hline \multirow{2}{*}{$\begin{array}{l}\text { Cluster } \\
\text { site }\end{array}$} & \multirow{2}{*}{$\begin{array}{c}\text { Site } \\
\text { identification } \\
\text { No. }\end{array}$} & \multirow[b]{2}{*}{ Well depth } & \multicolumn{4}{|c|}{ Type of analyses } \\
\hline & & & $\begin{array}{c}\text { Major } \\
\text { ions }\end{array}$ & $\begin{array}{l}\text { Trace } \\
\text { elements }\end{array}$ & $\begin{array}{c}\text { Stable } \\
\text { isotopes }\end{array}$ & Tritium \\
\hline \multirow[t]{3}{*}{3} & 363902120242521 & 3 & $\mathbf{x x}$ & $\mathbf{x x}$ & -- & -- \\
\hline & 363902120242522 & 6 & $x x$ & $\mathbf{x x}$ & $\mathbf{x x}$ & -- \\
\hline & 363902120242523 & 9 & $\mathbf{x x}$ & $\mathbf{x x}$ & $\mathrm{xx}$ & -- \\
\hline \multirow[t]{3}{*}{4} & 363902120242524 & 3 & $\mathbf{x x}$ & $\mathbf{x x}$ & -- & $x x$ \\
\hline & 363902120242525 & 6 & $\mathbf{x x}$ & $\mathbf{x x}$ & $\mathbf{x x}$ & $\mathbf{x x}$ \\
\hline & 363902120242526 & 12 & $\mathbf{x x}$ & $\mathbf{x x}$ & $\mathbf{x x}$ & $\mathbf{x x}$ \\
\hline \multirow[t]{3}{*}{5} & 363902120242527 & 3 & $\mathbf{x x}$ & $\mathbf{x x}$ & -- & -- \\
\hline & 363902120242528 & 6 & $\mathbf{x x}$ & $\mathbf{x x}$ & $\mathbf{x x}$ & -- \\
\hline & 363902120242529 & 9 & $\mathbf{x x}$ & $\mathbf{x x}$ & $\mathbf{x x}$ & -- \\
\hline \multirow[t]{3}{*}{6} & 363902120242530 & 3 & $\mathbf{x x}$ & $\mathbf{x x}$ & -- & -- \\
\hline & 363902120242531 & 6 & -- & -- & -- & -- \\
\hline & 363902120242532 & 12 & $\mathbf{x x}$ & $\mathbf{x x}$ & $\mathbf{x x}$ & -- \\
\hline \multirow[t]{4}{*}{7} & 363902120242533 & 3 & $\mathbf{x x}$ & $\mathbf{x x}$ & -- & $\mathbf{x x}$ \\
\hline & 363902120242534 & 6 & $\mathbf{x x}$ & $\mathbf{x x}$ & $\mathbf{x x}$ & $\mathbf{x x}$ \\
\hline & 363902120242535 & 9 & $\mathbf{x X}$ & $\mathbf{x x}$ & $\mathbf{x x}$ & $\mathbf{x x}$ \\
\hline & 363902120242536 & 12 & $\mathbf{x x}$ & $x x$ & $\mathbf{x x}$ & $\mathbf{x x}$ \\
\hline \multirow[t]{4}{*}{9} & 363902120242537 & 3 & $\mathbf{x x}$ & $\mathbf{x x}$ & -- & $\mathbf{x x}$ \\
\hline & 363902120242538 & 6 & $\mathbf{x x}$ & $x x$ & $\mathbf{x x}$ & $\mathbf{x x}$ \\
\hline & 363902120242539 & 9 & $\mathbf{x x}$ & $\mathbf{x x}$ & $\mathbf{x x}$ & $x x$ \\
\hline & 363902120242540 & 12 & $\mathbf{x x}$ & $\mathbf{x x}$ & $\mathbf{x x}$ & $x x$ \\
\hline \multirow[t]{3}{*}{10} & 363902120242541 & 3 & $\mathbf{x x}$ & $\mathbf{x x}$ & -- & -- \\
\hline & 363902120242542 & 6 & $\mathbf{x x}$ & $\mathbf{x x}$ & $\mathbf{x x}$ & -- \\
\hline & 363902120242543 & 9 & $\mathbf{x x}$ & $x x$ & $x x$ & -- \\
\hline \multirow[t]{3}{*}{11} & 363902120242544 & 3 & $\mathbf{x x}$ & $\mathbf{x x}$ & -- & -- \\
\hline & 363902120242545 & 6 & $\mathbf{x x}$ & $\mathbf{x x}$ & -- & -- \\
\hline & 363902120242546 & 12 & $\mathbf{x x}$ & $x x$ & $\mathbf{x x}$ & -- \\
\hline \multirow[t]{3}{*}{12} & 363902120242547 & 3 & $\mathbf{x x}$ & $\mathbf{x x}$ & -- & $x x$ \\
\hline & 363902120242548 & 6 & -- & -- & -- & -- \\
\hline & 363902120242549 & 9 & $\mathbf{x x}$ & $\mathbf{x x}$ & -- & $\mathbf{x x}$ \\
\hline \multirow[t]{3}{*}{13} & 363902120242550 & 3 & $\mathbf{x x}$ & $\mathbf{x x}$ & -- & -- \\
\hline & 363902120242551 & 6 & $\mathbf{x x}$ & $x x$ & $\mathbf{x x}$ & $x x$ \\
\hline & 363902120242552 & 12 & $\mathbf{x X}$ & $\mathbf{x x}$ & $\mathbf{x x}$ & $\mathbf{x x}$ \\
\hline \multirow[t]{3}{*}{14} & 363902120242553 & 3 & $\mathbf{x x}$ & $\mathbf{x x}$ & -- & -- \\
\hline & 363902120242554 & 6 & $\mathbf{x x}$ & $\mathbf{x x}$ & $\mathbf{x x}$ & $x x$ \\
\hline & 363902120242555 & 8 & $\mathbf{x x}$ & $x x$ & $\mathbf{x x}$ & $\mathbf{x x}$ \\
\hline \multirow[t]{3}{*}{15} & 363902120242556 & 3 & $\mathbf{x x}$ & $\mathbf{x x}$ & -- & -- \\
\hline & 363902120242557 & 6 & $\mathbf{x x}$ & $x x$ & $\mathbf{x x}$ & $\mathbf{x x}$ \\
\hline & 363902120242558 & 12 & $\mathbf{x x}$ & $x x$ & $\mathbf{x x}$ & $x x$ \\
\hline
\end{tabular}


Table 3. Field measurements and chemical analysis for major ions, dissolved organic carbon, stable

[Cluster site: Site at which one to five observation wells were installed at different depths. Well depth: Depth, in meters $\mathrm{mV}$, millivolt; ${ }^{\circ} \mathrm{C}$, degrees Celsius; $\mathrm{mg} / \mathrm{L}$, microgram per liter; $\mathrm{TU}$, tritium unit; $<$, actual value is less than value shown]

\begin{tabular}{|c|c|c|c|c|c|c|c|c|c|}
\hline \multirow{2}{*}{$\begin{array}{l}\text { Cluster } \\
\text { site }\end{array}$} & \multirow{2}{*}{$\begin{array}{l}\text { Well } \\
\text { depth }\end{array}$} & \multirow{2}{*}{ Date } & \multirow{2}{*}{$\begin{array}{c}\text { Specific } \\
\text { conductance } \\
(\mu \mathrm{S} / \mathrm{cm})\end{array}$} & \multirow{2}{*}{$\begin{array}{c}\mathrm{pH} \\
\text { (standard } \\
\text { units) }\end{array}$} & \multirow{2}{*}{$\begin{array}{l}\text { Oxidation } \\
\text { reduction } \\
\text { potential } \\
(\mathrm{mV})\end{array}$} & \multirow{2}{*}{$\begin{array}{c}\text { Temperature, } \\
\text { water } \\
\left({ }^{\circ} \mathrm{C}\right)\end{array}$} & \multirow{2}{*}{$\begin{array}{l}\text { Oxygen, } \\
\text { dissolved } \\
(\mathrm{mg} / \mathrm{L})\end{array}$} & \multirow[b]{2}{*}{$\begin{array}{l}\text { Calcium, } \\
\text { dissolved }\end{array}$} & \multirow[b]{2}{*}{$\begin{array}{c}\text { Magnesium, } \\
\text { dissolved }\end{array}$} \\
\hline & & & & & & & & & \\
\hline EW1 & 4 & $\begin{array}{l}2-04-86 \\
7-17-86 \\
7-30-86\end{array}$ & $\begin{array}{r}-- \\
9,700 \\
9,000\end{array}$ & $\begin{array}{l}7.02 \\
7.20 \\
7.30\end{array}$ & $\begin{array}{r}-- \\
354 \\
386\end{array}$ & $\begin{array}{l}16.0 \\
22.5 \\
24.0\end{array}$ & $\begin{array}{r}0.2 \\
.5 \\
.1\end{array}$ & $\begin{array}{r}-- \\
440\end{array}$ & $\begin{array}{l}270 \\
260 \\
260\end{array}$ \\
\hline EW2 & 4 & $2-04-86$ & 11,300 & 7.45 & - & 16.0 & .2 & 450 & 200 \\
\hline EW3 & 4 & $2-04-86$ & 10,700 & 7.20 & 215 & 17.0 & .5 & 490 & 160 \\
\hline EW4 & 4 & $\begin{array}{l}7-17-86 \\
7-30-86\end{array}$ & $\begin{array}{l}20,700 \\
17,300\end{array}$ & $\begin{array}{l}7.30 \\
7.40\end{array}$ & 390 & $\begin{array}{l}20.0 \\
23.0\end{array}$ & $\begin{array}{l}3.3 \\
4.2\end{array}$ & $\begin{array}{l}490 \\
500\end{array}$ & $\begin{array}{l}370 \\
310\end{array}$ \\
\hline EW5 & 4 & $\begin{array}{l}7-17-86 \\
7-30-86\end{array}$ & $\begin{array}{l}20,400 \\
19,100\end{array}$ & $\begin{array}{l}7.20 \\
7.10\end{array}$ & $\begin{array}{l}381 \\
233\end{array}$ & $\begin{array}{l}22.0 \\
22.5\end{array}$ & $\begin{array}{l}2.6 \\
1.2\end{array}$ & $\begin{array}{l}360 \\
430\end{array}$ & $\begin{array}{l}170 \\
440\end{array}$ \\
\hline EW6 & 4 & $\begin{array}{l}7-17-86 \\
7-30-86\end{array}$ & $\begin{array}{l}5,920 \\
5,850\end{array}$ & $\begin{array}{l}7.50 \\
7.50\end{array}$ & $\begin{array}{l}446 \\
391\end{array}$ & $\begin{array}{l}22.0 \\
21.0\end{array}$ & $\begin{array}{l}.8 \\
.4\end{array}$ & $\begin{array}{l}360 \\
410\end{array}$ & $\begin{array}{l}170 \\
190\end{array}$ \\
\hline MA & 15 & $6-30-87$ & 9,240 & 7.60 & 372 & 20.0 & 6.0 & 530 & 350 \\
\hline MB & 15 & $3-31-87$ & 7,500 & 7.54 & 354 & 23.0 & 3.2 & 490 & 350 \\
\hline MBS & 8.5 & $\begin{array}{l}4-01-87 \\
9-01-88\end{array}$ & $\begin{array}{l}22,400 \\
22,900\end{array}$ & $\begin{array}{l}7.55 \\
7.54\end{array}$ & $\begin{array}{r}331 \\
--\end{array}$ & $\begin{array}{l}22.5 \\
19.5\end{array}$ & $\begin{array}{r}.3 \\
1.8\end{array}$ & $\begin{array}{l}480 \\
580\end{array}$ & $\begin{array}{l}350 \\
730\end{array}$ \\
\hline MCS & 8.5 & $4-01-87$ & 21,800 & 7.62 & 355 & 20.0 & .3 & 540 & 610 \\
\hline MDS & 8 & 4-01-87 & 23,400 & 7.59 & 370 & 19.5 & 1.2 & 530 & 610 \\
\hline MF & $\begin{array}{l}3.5 \\
6 \\
9\end{array}$ & $\begin{array}{l}10-22-87 \\
10-22-87 \\
10-22-87\end{array}$ & $\begin{array}{l}5,850 \\
3,360 \\
9,470\end{array}$ & $\begin{array}{l}7.27 \\
7.51 \\
7.58\end{array}$ & $\begin{array}{l}403 \\
209 \\
218\end{array}$ & $\begin{array}{l}23.5 \\
21.0 \\
20.0\end{array}$ & $\begin{array}{r}.2 \\
.2 \\
1.0\end{array}$ & $\begin{array}{l}370 \\
470 \\
370\end{array}$ & $\begin{array}{l}130 \\
110 \\
260\end{array}$ \\
\hline M1 & $\begin{array}{r}3 \\
6 \\
9 \\
12 \\
15\end{array}$ & $\begin{array}{l}6-11-87 \\
7-20-88 \\
6-11-87 \\
7-20-88 \\
6-11-87 \\
7-01-87 \\
6-11-87\end{array}$ & $\begin{array}{r}9,900 \\
10,100 \\
8,440 \\
9,730 \\
13,000 \\
14,700 \\
9,500\end{array}$ & $\begin{array}{l}7.50 \\
7.38 \\
7.90 \\
7.75 \\
7.80 \\
7.80 \\
7.50\end{array}$ & $\begin{array}{l}320 \\
331 \\
291 \\
290 \\
297 \\
344 \\
235\end{array}$ & $\begin{array}{l}21.5 \\
20.5 \\
22.0 \\
24.5 \\
22.0 \\
22.0 \\
26.0\end{array}$ & $\begin{array}{r}3.2 \\
1.9 \\
.1 \\
.2 \\
.1 \\
.1 \\
3.0\end{array}$ & $\begin{array}{l}440 \\
170 \\
360 \\
290 \\
360 \\
520 \\
490\end{array}$ & $\begin{array}{l}260 \\
290 \\
310 \\
280 \\
430 \\
350 \\
440\end{array}$ \\
\hline M4 & $\begin{array}{r}6 \\
9 \\
15\end{array}$ & $\begin{array}{l}6-10-87 \\
7-22-88 \\
6-10-87 \\
7-20-88 \\
6-10-87 \\
7-20-88\end{array}$ & $\begin{array}{r}19,000 \\
19,800 \\
16,200 \\
17,900 \\
8,930 \\
11,700\end{array}$ & $\begin{array}{l}7.80 \\
7.72 \\
7.90 \\
7.84 \\
7.60 \\
7.53\end{array}$ & $\begin{array}{l}391 \\
410 \\
365 \\
268 \\
422 \\
281\end{array}$ & $\begin{array}{l}23.0 \\
25.5 \\
24.0 \\
23.5 \\
24.5 \\
27.0\end{array}$ & $\begin{array}{r}4.3 \\
4.2 \\
.2 \\
.2 \\
2.8 \\
.5\end{array}$ & $\begin{array}{l}410 \\
460 \\
370 \\
390 \\
460 \\
420\end{array}$ & $\begin{array}{l}430 \\
540 \\
540 \\
444 \\
410 \\
470\end{array}$ \\
\hline M5 & $\begin{array}{l}6 \\
9\end{array}$ & $\begin{array}{l}6-09-87 \\
7-21-88 \\
6-09-87 \\
7-21-88\end{array}$ & $\begin{array}{r}9,930 \\
10,400 \\
12,600 \\
14,500\end{array}$ & $\begin{array}{l}7.90 \\
7.74 \\
8.00 \\
7.89\end{array}$ & $\begin{array}{l}293 \\
380 \\
278 \\
350\end{array}$ & $\begin{array}{l}20.0 \\
27.0 \\
21.0 \\
21.0\end{array}$ & $\begin{array}{l}.2 \\
.1 \\
.1 \\
.1\end{array}$ & $\begin{array}{l}450 \\
300 \\
410 \\
140\end{array}$ & $\begin{array}{l}250 \\
230 \\
230 \\
400\end{array}$ \\
\hline
\end{tabular}


isotopes of hydrogen and oxygen, and tritium

below land surface, of each observation well completed at cluster site. --, no data. $\mu \mathrm{S} / \mathrm{cm}$, microseimen per centimeter

\begin{tabular}{|c|c|c|c|c|c|c|c|c|c|}
\hline \multicolumn{6}{|c|}{ Major ions, in milligrams per liter } & \multirow{2}{*}{$\begin{array}{l}\text { Carbon, } \\
\text { organic, } \\
\text { dissolved } \\
\text { (as C) }\end{array}$} & \multirow{2}{*}{$\begin{array}{c}{ }^{2} \mathrm{H} /{ }^{1} \mathrm{H} \\
\text { stable } \\
\text { isotope } \\
\text { ratio } \\
\text { (per mil) }\end{array}$} & \multirow{2}{*}{$\begin{array}{c}{ }^{18} \mathrm{O} /{ }^{16} \mathrm{O} \\
\text { stable } \\
\text { isotope } \\
\text { ratio } \\
\text { (per mil) }\end{array}$} & \multirow{2}{*}{$\begin{array}{l}\text { Tritium, } \\
\text { in water } \\
\text { molecules } \\
\text { (TU) }\end{array}$} \\
\hline $\begin{array}{l}\text { Sodium, } \\
\text { dissolved }\end{array}$ & $\begin{array}{c}\text { Potassium, } \\
\text { dissolved }\end{array}$ & $\begin{array}{l}\text { Bicarbonate, } \\
\text { whole water }\end{array}$ & $\begin{array}{c}\text { Sulfate, } \\
\text { dissolved }\end{array}$ & $\begin{array}{l}\text { Chloride, } \\
\text { dissolved }\end{array}$ & $\begin{array}{c}\text { Silica, } \\
\text { dissolved }\end{array}$ & & & & \\
\hline 1,400 & 1.4 & 442 & 3,900 & -- & 76 & 8.0 & 58.5 & 6.9 & -- \\
\hline 1,700 & 2.1 & -- & 4,000 & 1,200 & 74 & 11 & -- & -- & -- \\
\hline 2,300 & 1.6 & 464 & 4,000 & 1,100 & 78 & 9.2 & -- & -- & 15.7 \\
\hline 1,800 & 2.9 & 356 & 6,400 & 760 & 88 & 6.0 & -59.0 & -6.8 & -- \\
\hline 2,400 & 4.2 & 341 & 5,300 & 950 & 48 & 7.0 & -59.5 & -6.6 & -- \\
\hline 4,600 & 13 & 693 & 8,900 & 3,200 & 38 & 21 & -- & -- & -- \\
\hline 2,800 & 8.1 & 518 & 7,300 & 2,400 & 39 & 17 & -- & -- & 4.2 \\
\hline 4,500 & 4.2 & 636 & 7,700 & 3,500 & 53 & 22 & -- & -- & -- \\
\hline 3,600 & 3.6 & 454 & 7,400 & 3,500 & 53 & 21 & -- & -- & 1.8 \\
\hline 940 & 3.2 & 611 & 3,500 & 72 & 48 & 7.0 & -- & -- & -- \\
\hline 1,700 & 2.9 & 177 & 3,600 & 97 & 48 & 4.9 & -- & -- & 13.6 \\
\hline 1,300 & 1.8 & 122 & 9,300 & 140 & 32 & 1.6 & -57.0 & -6.9 & 1.5 \\
\hline 990 & 2.2 & 136 & 3,700 & 840 & 50 & 1.8 & -60.0 & -7.4 & $<.8$ \\
\hline 3,900 & 3.4 & 213 & 6,200 & 4,900 & 33 & 14 & -56.0 & -5.6 & 1.0 \\
\hline 5,000 & 3.6 & 230 & 6,800 & 4,800 & 35 & 15 & -55.0 & -5.0 & $<.8$ \\
\hline 4,000 & 3.6 & 217 & 5,900 & 4,700 & 34 & 13 & -55.5 & -5.5 & 2.2 \\
\hline 4,500 & 3.9 & 243 & 6,800 & 5,400 & 34 & 16 & -54.5 & -5.1 & $<.8$ \\
\hline 970 & 2.7 & 355 & 3,600 & 66 & 59 & -- & -72.0 & -9.2 & 15.0 \\
\hline 220 & 0.9 & 218 & 1,400 & 50 & 59 & -- & -69.5 & -9.1 & 12.1 \\
\hline 1,900 & 2.9 & 164 & 4,700 & 600 & 54 & 4.3 & -63.0 & -7.6 & 3.3 \\
\hline 2,200 & 2.6 & 437 & 5,100 & 590 & 62 & 9.1 & -67.5 & -8.7 & 12.2 \\
\hline 2,000 & 1.8 & 386 & 4,900 & 520 & 63 & 7.4 & -66.0 & -8.7 & 11.1 \\
\hline 2,000 & 2.6 & 170 & 5,300 & 180 & 34 & 5.0 & -63.0 & -8.2 & 5.5 \\
\hline 1,900 & 2.4 & 161 & 5,500 & 260 & 34 & 9.2 & -67.0 & -8.3 & 7.3 \\
\hline 3,300 & 2.0 & 174 & 8,700 & 150 & 34 & 4.4 & -61.0 & -7.3 & $<.8$ \\
\hline 3,300 & 1.7 & 182 & 3,700 & 1,000 & 44 & 4.0 & -60.0 & -7.1 & 1.1 \\
\hline 1,700 & 2.0 & 132 & 4,800 & 1,000 & 46 & -- & -57.5 & -6.5 & -- \\
\hline 5,100 & 9.0 & 294 & 9,800 & 1,900 & 26 & 11 & -56.5 & -6.3 & 6.8 \\
\hline 5,300 & 5.0 & 280 & 11,000 & 1,800 & 24 & 8.8 & -57.5 & -6.4 & -- \\
\hline 4,200 & 2.8 & 171 & 6,700 & 910 & 26 & 4.7 & -- & -- & $<.8$ \\
\hline 3,900 & 3.0 & 163 & 10,000 & 690 & 26 & 3.8 & -61.5 & -7.4 & .9 \\
\hline 1,900 & 1.7 & 199 & 6,500 & 300 & 53 & 2.8 & -61.0 & -7.5 & .9 \\
\hline 2,300 & 1.9 & 186 & 6,900 & 370 & 52 & 2.5 & -62.5 & -7.6 & $<.8$ \\
\hline 2,300 & 3.1 & 182 & 5,200 & 840 & 42 & 5.6 & -59.5 & -7.5 & 11.0 \\
\hline 2,000 & 2.5 & 175 & 4,600 & 750 & 42 & 4.1 & -62.0 & -7.5 & 10.7 \\
\hline 2,400 & 1.5 & 116 & 8,500 & 290 & 28 & 3.7 & -63.0 & -7.9 & 15.9 \\
\hline 3,400 & 2.3 & 115 & 8,600 & 380 & 28 & 3.3 & -62.5 & -7.7 & 19.6 \\
\hline
\end{tabular}


Table 3. Field measurements and chemical analysis for major ions, dissolved organic carbon, stable

\begin{tabular}{|c|c|c|c|c|c|c|c|c|c|}
\hline \multirow{2}{*}{$\begin{array}{l}\text { Cluster } \\
\text { site }\end{array}$} & \multirow{2}{*}{$\begin{array}{l}\text { Well } \\
\text { depth }\end{array}$} & \multirow{2}{*}{ Date } & \multirow{2}{*}{$\begin{array}{c}\text { Specific } \\
\text { conductance } \\
(\mu \mathrm{S} / \mathrm{cm})\end{array}$} & \multirow{2}{*}{$\begin{array}{c}\mathrm{pH} \\
\text { (standard } \\
\text { units) }\end{array}$} & \multirow{2}{*}{$\begin{array}{l}\text { Oxidation } \\
\text { reduction } \\
\text { potential } \\
(\mathrm{mV})\end{array}$} & \multirow{2}{*}{$\begin{array}{c}\text { Temperature, } \\
\text { water } \\
\left({ }^{\circ} \mathrm{C}\right)\end{array}$} & \multirow{2}{*}{$\begin{array}{l}\text { Oxygen, } \\
\text { dissolved } \\
(\mathrm{mg} / \mathrm{L})\end{array}$} & \multirow[b]{2}{*}{$\begin{array}{l}\text { Calcium, } \\
\text { dissolved }\end{array}$} & \multirow[b]{2}{*}{$\begin{array}{c}\text { Magnesium, } \\
\text { dissolved }\end{array}$} \\
\hline & & & & & & & & & \\
\hline M5 & $\begin{array}{l}12 \\
15\end{array}$ & $\begin{array}{l}7-01-87 \\
7-21-88 \\
6-09-87 \\
7-21-88\end{array}$ & $\begin{array}{r}7,480 \\
7,410 \\
7,960 \\
10,500\end{array}$ & $\begin{array}{l}8.00 \\
7.73 \\
7.60 \\
7.75\end{array}$ & $\begin{array}{l}336 \\
381 \\
273 \\
389\end{array}$ & $\begin{array}{l}22.0 \\
27.0 \\
23.0 \\
20.0\end{array}$ & $\begin{array}{r}4.0 \\
.4 \\
1.0 \\
.3\end{array}$ & $\begin{array}{l}360 \\
450 \\
470 \\
250\end{array}$ & $\begin{array}{l}570 \\
280 \\
220 \\
390\end{array}$ \\
\hline M8 & $\begin{array}{r}3 \\
6 \\
12 \\
15\end{array}$ & $\begin{array}{l}10-20-87 \\
10-20-87 \\
10-20-87 \\
10-20-87\end{array}$ & $\begin{array}{l}3,380 \\
6,090 \\
7,020 \\
8,900\end{array}$ & $\begin{array}{l}7.00 \\
7.60 \\
7.40 \\
7.74\end{array}$ & $\begin{array}{l}350 \\
313 \\
333 \\
326\end{array}$ & $\begin{array}{l}21.5 \\
21.0 \\
20.0 \\
21.5\end{array}$ & $\begin{array}{r}2.1 \\
.5 \\
1.2 \\
6.2\end{array}$ & $\begin{array}{l}180 \\
510 \\
410 \\
300\end{array}$ & $\begin{array}{r}53 \\
150 \\
160 \\
340\end{array}$ \\
\hline M10 & $\begin{array}{r}3 \\
6 \\
12 \\
15\end{array}$ & $\begin{array}{l}10-21-87 \\
10-21-87 \\
10-21-87 \\
10-21-87\end{array}$ & $\begin{array}{r}4,680 \\
8,880 \\
10,100 \\
14,800\end{array}$ & $\begin{array}{l}7.36 \\
7.99 \\
7.98 \\
7.90\end{array}$ & $\begin{array}{l}390 \\
369 \\
370 \\
377\end{array}$ & $\begin{array}{l}23.0 \\
19.5 \\
20.0 \\
19.5\end{array}$ & $\begin{array}{l}.3 \\
.3 \\
.5 \\
.3\end{array}$ & $\begin{array}{l}480 \\
370 \\
340 \\
350\end{array}$ & $\begin{array}{l}100 \\
170 \\
220 \\
380\end{array}$ \\
\hline NW1 & 4 & $2-04-86$ & 7,250 & 7.37 & -- & 16.5 & .8 & 500 & 210 \\
\hline NW4 & 4 & $2-04-86$ & 25,800 & 7.23 & 191 & 15.0 & 2.3 & 580 & 130 \\
\hline NW7 & 4 & $2-03-86$ & 13,400 & 7.22 & 326 & 16.0 & 1.9 & 460 & 150 \\
\hline NW10 & 4 & $\begin{array}{l}1-31-86 \\
7-22-88\end{array}$ & $\begin{array}{r}23,800 \\
7,480\end{array}$ & $\begin{array}{l}7.55 \\
7.26\end{array}$ & $\begin{array}{l}319 \\
366\end{array}$ & $\begin{array}{l}16.0 \\
21.0\end{array}$ & $\begin{array}{l}.4 \\
.2\end{array}$ & $\begin{array}{l}410 \\
460\end{array}$ & $\begin{array}{l}230 \\
210\end{array}$ \\
\hline NW13 & 4 & $2-04-86$ & 14,600 & 7.42 & -. & 16.0 & 2.5 & 520 & 290 \\
\hline SE1 & 4 & $\begin{array}{l}2-05-86 \\
5-23-86 \\
7-16-86 \\
7-29-86\end{array}$ & $\begin{array}{r}. . \\
15,400 \\
15,900 \\
15,500\end{array}$ & $\begin{array}{l}7.05 \\
7.08 \\
7.20 \\
7.10\end{array}$ & $\begin{array}{l}363 \\
393 \\
417 \\
465\end{array}$ & $\begin{array}{l}16.5 \\
18.5 \\
23.0 \\
24.0\end{array}$ & $\begin{array}{r}1.3 \\
.6 \\
.2 \\
.2\end{array}$ & $\begin{array}{l}540 \\
540 \\
510 \\
480\end{array}$ & $\begin{array}{l}330 \\
410 \\
410 \\
390\end{array}$ \\
\hline SE4 & 4 & $\begin{array}{l}2-05-86 \\
5-22-86 \\
7-15-86 \\
7-29-86\end{array}$ & $\begin{array}{r}-- \\
9,580 \\
11,700 \\
11,800\end{array}$ & $\begin{array}{l}7.06 \\
7.45 \\
7.50 \\
7.40\end{array}$ & $\begin{array}{l}239 \\
299 \\
347 \\
369\end{array}$ & $\begin{array}{l}17.0 \\
19.0 \\
24.0 \\
20.5\end{array}$ & $\begin{array}{r}2.4 \\
2.3 \\
.2 \\
.8\end{array}$ & $\begin{array}{l}510 \\
480 \\
430 \\
440\end{array}$ & $\begin{array}{l}270 \\
280 \\
300 \\
300\end{array}$ \\
\hline SE7 & 4 & $\begin{array}{l}2-05-86 \\
5-21-86 \\
7-16-86 \\
7-29-86\end{array}$ & $\begin{array}{r}-. \\
26,100 \\
26,500 \\
24,800\end{array}$ & $\begin{array}{l}7.35 \\
7.29 \\
7.40 \\
7.40\end{array}$ & $\begin{array}{l}269 \\
292 \\
322 \\
389\end{array}$ & $\begin{array}{l}18.0 \\
20.5 \\
24.0 \\
27.0\end{array}$ & $\begin{array}{l}.6 \\
.3 \\
.5 \\
.6\end{array}$ & $\begin{array}{l}500 \\
500 \\
460 \\
480\end{array}$ & $\begin{array}{l}390 \\
550 \\
540 \\
550\end{array}$ \\
\hline SE10 & 4 & $\begin{array}{l}2-05-86 \\
5-21-86 \\
7-31-86 \\
9-01-88\end{array}$ & $\begin{array}{l}17,300 \\
12,900 \\
12,600 \\
14,500\end{array}$ & $\begin{array}{l}7.50 \\
7.39 \\
7.50 \\
7.33\end{array}$ & $\begin{array}{r}169 \\
158 \\
354 \\
--\end{array}$ & $\begin{array}{l}16.0 \\
21.0 \\
23.5 \\
23.0\end{array}$ & $\begin{array}{r}2.6 \\
1.2 \\
.7 \\
.4\end{array}$ & $\begin{array}{l}500 \\
440 \\
400 \\
260\end{array}$ & $\begin{array}{l}310 \\
290 \\
270 \\
370\end{array}$ \\
\hline SE13 & 4 & $\begin{array}{l}2-05-86 \\
5-21-86\end{array}$ & 15,800 & $\begin{array}{l}7.08 \\
7.17\end{array}$ & $\begin{array}{l}282 \\
242\end{array}$ & $\begin{array}{l}17.0 \\
18.0\end{array}$ & $\begin{array}{l}.8 \\
.8\end{array}$ & $\begin{array}{l}680 \\
700\end{array}$ & $\begin{array}{l}300 \\
340\end{array}$ \\
\hline
\end{tabular}


isotopes of hydrogen and oxygen, and tritium--Continued

\begin{tabular}{|c|c|c|c|c|c|c|c|c|c|}
\hline \multicolumn{6}{|c|}{ Major ions, in milligrams per liter } & \multirow{2}{*}{$\begin{array}{l}\text { Carbon, } \\
\text { organic, } \\
\text { dissolved } \\
\quad(\text { as C) }\end{array}$} & \multirow{2}{*}{$\begin{array}{c}{ }^{2} \mathrm{H} /{ }^{1} \mathrm{H} \\
\text { stable } \\
\text { isotope } \\
\text { ratio } \\
\text { (per mil) }\end{array}$} & \multirow{2}{*}{$\begin{array}{c}{ }^{18} \mathrm{O} /{ }^{16} \mathrm{O} \\
\text { stable } \\
\text { isotope } \\
\text { ratio } \\
\text { (per mil) }\end{array}$} & \multirow{2}{*}{$\begin{array}{c}\text { Tritium, } \\
\text { in water } \\
\text { molecules } \\
\text { (TU) }\end{array}$} \\
\hline $\begin{array}{r}\text { Sodium, } \\
\text { dissolved }\end{array}$ & $\begin{array}{l}\text { Potassium, } \\
\text { dissolved }\end{array}$ & $\begin{array}{l}\text { Bicarbonate, } \\
\text { whole water }\end{array}$ & $\begin{array}{c}\text { Sulfate, } \\
\text { dissolved }\end{array}$ & $\begin{array}{l}\text { Chloride, } \\
\text { dissolved }\end{array}$ & $\begin{array}{c}\text { Silica, } \\
\text { dissolved }\end{array}$ & & & & \\
\hline 1,200 & 1.3 & 98 & 1,500 & 190 & 33 & 2.8 & -61.5 & -8.1 & 31.9 \\
\hline 1,200 & 1.3 & 112 & 3,800 & 460 & 34 & 2.5 & -64.0 & -8.1 & 26.5 \\
\hline 3,700 & 2.2 & 134 & 7,100 & 460 & 43 & 3.3 & -61.0 & -7.6 & 11.6 \\
\hline 2,100 & 1.1 & 98 & 6,100 & 380 & 36 & 2.5 & -- & -- & 25.1 \\
\hline 630 & 5.8 & 563 & 800 & 330 & 59 & -- & -69.0 & -9.0 & 15.4 \\
\hline 1,200 & 5.8 & 280 & 3,200 & 600 & 50 & -- & -63.5 & -7.9 & 11.2 \\
\hline 1,400 & 2.4 & 162 & 4,000 & 560 & 46 & .. & -64.0 & -7.7 & $<.8$ \\
\hline 2,000 & 2.3 & 118 & 6,200 & 500 & 32 & -- & -59.5 & -7.0 & .9 \\
\hline 640 & 4.2 & 376 & 2,100 & 390 & 63 & -- & -67.0 & -8.7 & 13.2 \\
\hline 1,800 & 3.5 & 239 & 5,100 & 430 & 43 & -- & -63.0 & -7.8 & 15.8 \\
\hline 2,000 & 3.3 & 188 & 5,200 & 580 & 38 & -- & -62.5 & -7.4 & 3.4 \\
\hline 3,300 & 3.4 & 173 & 6,500 & 2,100 & 34 & -- & -57.0 & -5.9 & 1.6 \\
\hline 910 & 4.7 & 331 & 4,000 & 480 & 45 & 6.0 & -65.5 & -8.1 & -- \\
\hline 730 & 4.2 & 397 & 2,900 & 480 & 60 & 4.8 & -64.5 & -8.0 & -- \\
\hline 1,200 & 3.4 & 424 & 4,800 & 390 & 68 & 4.1 & -63.5 & -8.0 & -- \\
\hline 2,500 & 3.5 & -- & 9,600 & 870 & 72 & 7.4 & -60.0 & -7.1 & -- \\
\hline 1,300 & 3.2 & 356 & 3,300 & 620 & 71 & 6.1 & -66.5 & -8.6 & 10.4 \\
\hline 2,100 & 1.6 & 625 & 5,600 & 1,500 & 70 & 13 & -63.5 & -7.9 & -- \\
\hline 2,700 & 2.1 & 606 & 5,800 & 2,800 & 74 & 18 & -56.0 & -5.6 & -- \\
\hline 3,200 & 2.3 & 672 & 5,400 & 2,800 & 74 & 20 & -- & -- & -- \\
\hline 3,200 & 3.2 & 830 & 5,100 & 2,900 & 76 & 25 & -- & -- & -- \\
\hline 2,400 & 2.9 & 633 & 5,700 & 3,000 & 76 & 22 & -- & -- & 5.0 \\
\hline 2,100 & 2.1 & 220 & 5,700 & 1,600 & 64 & 7.3 & -57.0 & -5.9 & -- \\
\hline 1,900 & 2.0 & 281 & 5,400 & 970 & 63 & 6.3 & -- & -- & -- \\
\hline 2,300 & 2.0 & 290 & 5,000 & 1,700 & 61 & 8.1 & -- & -- & -- \\
\hline 3,500 & 2.2 & 217 & 5,500 & 1,700 & 68 & 7.8 & -- & -- & 4.5 \\
\hline 5,400 & 4.1 & 403 & 9,800 & 4,600 & 56 & 15 & -56.5 & -5.7 & -- \\
\hline 5,800 & 3.9 & 402 & 9,000 & 5,100 & 54 & 21 & -- & -- & -- \\
\hline 2,200 & 4.2 & 384 & 9,000 & 5,600 & 53 & 17 & -- & -- & -- \\
\hline 4,900 & 4.2 & 385 & 8,800 & 5,500 & 53 & 15 & -- & -- & 1.9 \\
\hline 3,200 & 3.0 & 434 & 7,000 & 2,900 & 66 & 18 & -58.5 & -6.1 & -- \\
\hline 2,700 & 2.5 & 369 & 6,600 & 1,100 & 64 & 13 & -- & -- & -- \\
\hline 2,100 & 3.1 & 349 & 6,700 & 990 & 70 & 53 & -- & -- & -- \\
\hline 3,400 & 2.4 & 358 & 6,600 & 1,500 & 69 & 10 & -61.5 & -7.0 & 5.4 \\
\hline 2,900 & 3.6 & 437 & 4,700 & 3,000 & 46 & 24 & .62 .5 & -6.1 & -- \\
\hline 3,100 & 3.4 & 408 & 4,100 & 3,300 & 46 & 21 & -- & -- & -- \\
\hline
\end{tabular}


Table 3. Field measurements and chemical analysis for major ions, dissolved organic carbon, stable

\begin{tabular}{|c|c|c|c|c|c|c|c|c|c|}
\hline \multirow{2}{*}{$\begin{array}{l}\text { Cluster } \\
\text { site }\end{array}$} & \multirow{2}{*}{$\begin{array}{l}\text { Well } \\
\text { depth }\end{array}$} & \multirow{2}{*}{ Date } & \multirow{2}{*}{$\begin{array}{c}\text { Specific } \\
\text { conductance } \\
(\mu \mathrm{S} / \mathrm{cm})\end{array}$} & \multirow{2}{*}{$\begin{array}{l}\mathrm{pH} \\
\text { (standard } \\
\text { units) }\end{array}$} & \multirow{2}{*}{$\begin{array}{c}\text { Oxidation } \\
\text { reduction } \\
\text { potential } \\
(\mathrm{mV})\end{array}$} & \multirow{2}{*}{$\begin{array}{c}\text { Temperature, } \\
\text { water } \\
\left({ }^{\circ} \mathrm{C}\right)\end{array}$} & \multirow{2}{*}{$\begin{array}{l}\text { Oxygen, } \\
\text { dissolved } \\
\text { (mg/L) }\end{array}$} & \multirow[b]{2}{*}{$\begin{array}{l}\text { Calcium, } \\
\text { dissolved }\end{array}$} & \multirow[b]{2}{*}{$\begin{array}{c}\text { Magnesium, } \\
\text { dissolved }\end{array}$} \\
\hline & & & & & & & & & \\
\hline \multirow[t]{7}{*}{1} & 3 & $7-30-86$ & 12,500 & 7.50 & 386 & 27.0 & 0.7 & 420 & 320 \\
\hline & & $8-12-86$ & 13,800 & 7.60 & 360 & 22.0 & .5 & 410 & 310 \\
\hline & & $8-30-88$ & 11,100 & 7.14 & -- & 25.5 & .5 & 330 & 300 \\
\hline & 6 & $3-05-86$ & 17,600 & 7.46 & 401 & 23.0 & 2.9 & -- & 270 \\
\hline & & $8-30-88$ & 16,400 & 7.45 & -- & 22.0 & 3.2 & 210 & 410 \\
\hline & 9 & $3-05-86$ & 18,800 & 7.69 & 455 & 21.0 & 2.7 & 410 & 370 \\
\hline & 12 & $3-05-86$ & 12,300 & 7.76 & 353 & 19.5 & 4.8 & 460 & 330 \\
\hline \multirow[t]{5}{*}{2} & 3 & $5-23-86$ & 18,500 & 7.21 & 391 & 20.5 & 4.6 & 620 & 470 \\
\hline & & $7-30-86$ & 17,700 & 7.10 & 372 & 23.0 & .6 & 510 & 440 \\
\hline & & $9-01-88$ & 16,200 & 7.11 & - & 28.5 & 1.5 & 620 & 390 \\
\hline & 12 & $2-28-86$ & 6,970 & 7.48 & 384 & 18.0 & 2.3 & 580 & 330 \\
\hline & & $9-01-88$ & 7,360 & 7.62 & -- & 28.5 & 2.9 & 520 & 360 \\
\hline \multirow[t]{4}{*}{3} & 3 & $7-31-86$ & 12,000 & 7.20 & 361 & 22.0 & 1.0 & 440 & 320 \\
\hline & & $8-12-86$ & 12,000 & 7.30 & 397 & 24.0 & .8 & 420 & 310 \\
\hline & 6 & $2-06-86$ & 15,200 & 7.64 & 340 & 15.5 & 1.6 & 460 & 330 \\
\hline & 9 & $2-06-86$ & 27,200 & 7.55 & 335 & 14.5 & 1.6 & 430 & 480 \\
\hline \multirow[t]{10}{*}{4} & 3 & $5-22-86$ & 12,800 & 7.47 & 316 & 21.0 & 5.8 & 460 & 290 \\
\hline & & $7-16-86$ & 13,400 & 7.00 & 370 & 22.0 & .7 & 440 & 300 \\
\hline & & $7-29-86$ & 13,400 & 7.10 & 390 & 23.0 & .8 & 450 & 310 \\
\hline & & $8-12-86$ & 14,100 & 7.20 & 369 & 22.0 & 1.1 & 440 & 300 \\
\hline & 6 & $2-06-86$ & 23,200 & 7.64 & 288 & 18.0 & .8 & 410 & 320 \\
\hline & & $7-16-86$ & 17,900 & 7.60 & 368 & 24.0 & .8 & 460 & 450 \\
\hline & & $7-29-86$ & 17,000 & 7.60 & 259 & 22.5 & .5 & 460 & 420 \\
\hline & 12 & $2-06-86$ & 10,200 & 8.20 & 425 & -- & 2.3 & 410 & 250 \\
\hline & & $7-16-86$ & 9,830 & 7.50 & 375 & 20.0 & 1.9 & 380 & 300 \\
\hline & & $7-29-86$ & 9,600 & 7.70 & 386 & 24.0 & 2.4 & 380 & 300 \\
\hline \multirow[t]{3}{*}{5} & 3 & $8-11-86$ & 14,900 & 7.70 & 346 & 20.5 & .4 & 470 & 360 \\
\hline & 6 & $2-06-86$ & 14,900 & 7.62 & 361 & 17.0 & .9 & 510 & 320 \\
\hline & 9 & $2-06-86$ & 23,000 & 7.61 & 370 & 15.5 & .9 & 480 & 490 \\
\hline \multirow[t]{2}{*}{6} & 3 & 8-13-86 & 14,300 & 7.30 & 376 & 25.0 & 1.0 & 460 & 330 \\
\hline & 12 & $2-07-86$ & 10,700 & 7.48 & 295 & 17.0 & .7 & 470 & 270 \\
\hline \multirow[t]{13}{*}{7} & 3 & $5-22-86$ & 11,300 & 7.40 & 289 & 23.0 & 1.9 & 460 & 290 \\
\hline & & $7-15-86$ & 11,700 & 7.30 & 392 & 23.0 & .4 & 400 & 280 \\
\hline & & $7-28-86$ & 13,000 & 7.40 & 352 & 23.0 & .6 & 440 & 300 \\
\hline & & $8-12-86$ & 12,400 & 7.50 & 340 & 24.0 & .3 & 410 & 290 \\
\hline & & $8-30-88$ & 12,400 & 7.19 & -- & 20.0 & 1.0 & 520 & 340 \\
\hline & 6 & 3-06-86 & 17,300 & 7.54 & 444 & 18.5 & 1.7 & 560 & 250 \\
\hline & & $7-15-86$ & 14,600 & 7.80 & 379 & 22.0 & .4 & 470 & 310 \\
\hline & & $7-29-86$ & 16,500 & 7.90 & 353 & 19.0 & .3 & 450 & 300 \\
\hline & & $8-30-88$ & 15,400 & 7.40 & -- & 24.0 & .5 & 480 & 330 \\
\hline & 9 & $2-11-86$ & 23,100 & 7.68 & 289 & 17.0 & .5 & 480 & 450 \\
\hline & & $7-15-86$ & 20,400 & 7.70 & 407 & 24.5 & .1 & 420 & 610 \\
\hline & & $7-29-86$ & 22,800 & 7.70 & 168 & 19.0 & .2 & 430 & 610 \\
\hline & & $8-30-88$ & 22,200 & 7.54 & -- & 28.0 & 1.7 & 560 & 640 \\
\hline
\end{tabular}


isotopes of hydrogen and oxygen, and tritium--Continued

\begin{tabular}{|c|c|c|c|c|c|c|c|c|c|}
\hline \multicolumn{6}{|c|}{ Major ions, in milligrams per liter } & \multirow{2}{*}{$\begin{array}{l}\text { Carbon, } \\
\text { organic, } \\
\text { dissolved } \\
\text { (as C) }\end{array}$} & \multirow{2}{*}{$\begin{array}{c}{ }^{2} \mathrm{H} /{ }^{1} \mathrm{H} \\
\text { stable } \\
\text { isotope } \\
\text { ratio } \\
\text { (per mil) }\end{array}$} & \multirow{2}{*}{$\begin{array}{c}{ }^{18} \mathrm{O} /{ }^{16} \mathrm{O} \\
\text { stable } \\
\text { isotope } \\
\text { ratio } \\
\text { (per mil) }\end{array}$} & \multirow{2}{*}{$\begin{array}{c}\text { Tritium, } \\
\text { in water } \\
\text { molecules } \\
\text { (TU) }\end{array}$} \\
\hline $\begin{array}{l}\text { Sodium, } \\
\text { dissolved }\end{array}$ & $\begin{array}{l}\text { Potassium, } \\
\text { dissolved }\end{array}$ & $\begin{array}{l}\text { Bicarbonate, } \\
\text { whole water }\end{array}$ & $\begin{array}{l}\text { Sulfate, } \\
\text { dissolved }\end{array}$ & $\begin{array}{l}\text { Chloride, } \\
\text { dissolved }\end{array}$ & $\begin{array}{c}\text { Silica, } \\
\text { dissolved }\end{array}$ & & & & \\
\hline 2,700 & 3.2 & 309 & 5,700 & 2,000 & 52 & 14 & -- & -- & 10.1 \\
\hline 2,700 & 3.6 & 403 & 5,200 & 1,900 & 50 & 14 & -- & -- & -- \\
\hline 2,200 & 2.6 & 300 & 5,200 & 940 & 54 & 8.0 & -65.0 & -7.7 & 6.0 \\
\hline 3,000 & 4.7 & 288 & 8,200 & -- & 41 & -- & -54.0 & -4.8 & 2.9 \\
\hline 3,700 & 4.2 & 220 & 7,700 & 1,900 & 38 & 7.2 & -55.0 & -5.2 & 1.7 \\
\hline 2,700 & 2.7 & 180 & 9,800 & 1,400 & 32 & 6.2 & -56.5 & -5.5 & $<.8$ \\
\hline 1,900 & 1.5 & 123 & 4,900 & 1,800 & 27 & 3.5 & -58.5 & -6.4 & $<.8$ \\
\hline 3,800 & 2.9 & 684 & 5,200 & 4,400 & 78 & 30 & -- & -- & -- \\
\hline 3,200 & 3.4 & 660 & 5,200 & 4,500 & 82 & 28 & -- & -- & 6.5 \\
\hline 4,200 & 2.6 & 582 & 5,300 & 1,200 & 73 & 27 & -56.0 & -5.8 & 3.7 \\
\hline 720 & 1.3 & 147 & 3,400 & 1,100 & 41 & -- & -58.0 & -6.7 & $<.8$ \\
\hline 880 & 1.7 & 99 & 3,100 & 1,000 & 41 & 2.2 & -59.5 & -6.9 & $<.8$ \\
\hline 80 & 3.0 & 637 & 4,900 & 1,700 & 57 & 67 & -- & -- & -. \\
\hline 2,400 & 3.5 & 841 & 4,800 & 1,700 & 55 & 12 & -- & -- & -- \\
\hline 2,500 & 4.0 & 222 & 7,600 & 1,700 & 38 & 8.0 & -53.5 & -5.4 & -- \\
\hline 3,700 & 4.1 & 161 & 12,000 & 2,800 & 30 & 13 & -51.5 & -4.0 & -- \\
\hline 2,600 & 5.0 & 586 & 6,100 & 1,600 & 64 & 11 & -- & -- & -- \\
\hline 2,700 & 6.3 & 701 & 5,900 & 1,600 & 33 & 12 & -- & -- & .. \\
\hline 1,400 & 5.9 & 596 & 6,000 & 1,800 & 35 & 11 & -. & -- & 12.0 \\
\hline 4,000 & 6.7 & 799 & 6,100 & 2,000 & 63 & 10 & -- & -- & -- \\
\hline 3,300 & 4.5 & 221 & 7,500 & 2,900 & 35 & 0.6 & -53.5 & -6.5 & -- \\
\hline 3,700 & 4.8 & 146 & 7,500 & 3,000 & 33 & 12 & -- & -- & -. \\
\hline 2,600 & 4.2 & 170 & 6,800 & 2,700 & 34 & 11 & -. & -. & 5.4 \\
\hline 1,500 & 1.8 & 116 & 4,800 & 1,100 & 30 & 1.5 & -58.0 & -6.5 & -- \\
\hline 1,800 & 2.1 & 203 & 3,900 & 1,100 & 30 & 3.4 & -- & -- & -- \\
\hline 2,400 & 1.7 & 108 & 4,200 & 1,200 & 30 & 2.5 & -- & -- & $<.8$ \\
\hline 3,000 & 4.4 & 252 & 5,900 & 2,400 & 32 & 8.2 & -- & -- & -- \\
\hline 2,700 & 4.0 & 195 & 6,300 & 2,200 & 37 & 9.0 & -56.5 & -5.4 & -- \\
\hline 4,600 & 4.4 & 146 & 8,700 & 4,200 & 30 & 8.0 & -52.5 & -4.2 & -- \\
\hline 2,900 & 9.5 & 751 & 5,800 & 2,300 & 56 & 11 & -- & -- & -- \\
\hline 1,700 & 1.7 & 126 & 5,100 & 1,100 & 28 & 1.8 & -59.5 & -6.6 & -- \\
\hline 2,300 & 3.4 & 344 & 5,800 & 1,400 & 72 & 8.7 & -- & -- & -- \\
\hline 2,500 & 3.3 & 414 & 5,700 & 1,400 & 38 & 9.6 & -- & .. & -- \\
\hline 1,800 & 3.7 & 360 & 5,200 & 1,400 & 78 & 5.7 & -- & -- & 7.8 \\
\hline 2,400 & 4.5 & 505 & 5,500 & 1,500 & 80 & 8.6 & -- & -- & -- \\
\hline 2,400 & 6.2 & 368 & 4,800 & 2,000 & 77 & 10 & -59.5 & -6.7 & 5.7 \\
\hline 2,900 & 3.9 & 190 & 6,500 & 2,500 & 37 & 11 & -55.5 & -5.1 & -- \\
\hline 3,500 & 3.7 & 229 & 6,100 & 2,800 & 35 & 14 & -- & -- & -- \\
\hline 2,200 & 3.9 & 191 & 5,900 & 2,900 & 35 & 12 & -- & -- & $<.8$ \\
\hline 3,300 & 3.4 & 196 & 6,400 & 2,500 & 36 & 6.9 & -55.5 & -5.3 & 1.6 \\
\hline 4,500 & 3.8 & 158 & 11,000 & 3,800 & 33 & .. & -53.0 & -4.5 & -- \\
\hline 5,200 & 3.5 & 166 & 9,000 & 4,300 & 32 & 9.2 & -- & -. & -- \\
\hline 2,000 & 3.7 & 145 & 9,000 & 4,200 & 32 & 8.3 & -- & -- & $<.8$ \\
\hline 4,800 & 3.7 & 152 & 8,200 & 3,700 & 32 & 7.0 & -52.5 & -4.7 & $<.8$ \\
\hline
\end{tabular}


Table 3. Field measurements and chemical analysis for major ions, dissolved organic carbon, stable

\begin{tabular}{|c|c|c|c|c|c|c|c|c|c|}
\hline \multirow{2}{*}{$\begin{array}{l}\text { Cluster } \\
\text { site }\end{array}$} & \multirow{2}{*}{$\begin{array}{l}\text { Well } \\
\text { depth }\end{array}$} & \multirow{2}{*}{ Date } & \multirow{2}{*}{$\begin{array}{c}\text { Specific } \\
\text { conductance } \\
(\mu \mathrm{S} / \mathrm{cm})\end{array}$} & \multirow{2}{*}{$\begin{array}{l}\mathrm{pH} \\
\text { (standard } \\
\text { units) }\end{array}$} & \multirow{2}{*}{$\begin{array}{c}\text { Oxidation } \\
\text { reduction } \\
\text { potential } \\
(\mathrm{mV})\end{array}$} & \multirow{2}{*}{$\begin{array}{c}\text { Temperature, } \\
\text { water } \\
\left({ }^{\circ} \mathrm{C}\right)\end{array}$} & \multirow{2}{*}{$\begin{array}{l}\text { Oxygen, } \\
\text { dissolved } \\
(\mathrm{mg} / \mathrm{L})\end{array}$} & \multirow[b]{2}{*}{$\begin{array}{l}\text { Calcium, } \\
\text { dissolved }\end{array}$} & \multirow[b]{2}{*}{$\begin{array}{c}\text { Magnesium, } \\
\text { dissolved }\end{array}$} \\
\hline & & & & & & & & & \\
\hline 7 & 12 & $\begin{array}{l}2-11-86 \\
7-15-86 \\
7-28-86 \\
8-30-88\end{array}$ & $\begin{array}{l}12,200 \\
10,400 \\
11,900 \\
14,700\end{array}$ & $\begin{array}{l}7.71 \\
8.00 \\
7.90 \\
8.71\end{array}$ & $\begin{array}{r}350 \\
337 \\
338 \\
--\end{array}$ & $\begin{array}{l}18.0 \\
22.0 \\
21.0 \\
20.0\end{array}$ & $\begin{array}{r}0.8 \\
.3 \\
.6 \\
.7\end{array}$ & $\begin{array}{l}470 \\
400 \\
410 \\
560\end{array}$ & $\begin{array}{l}270 \\
290 \\
300 \\
390\end{array}$ \\
\hline 9 & 12 & $\begin{array}{l}7-15-86 \\
7-28-86 \\
8-13-86 \\
3-06-86 \\
7-16-86 \\
7-28-86 \\
2-11-86 \\
7-16-86 \\
7-28-86 \\
2-28-86 \\
7-15-86 \\
7-29-86\end{array}$ & $\begin{array}{l}12,900 \\
13,300 \\
13,500 \\
15,700 \\
15,800 \\
16,100 \\
17,100 \\
21,700 \\
21,100 \\
13,700 \\
15,400 \\
13,900\end{array}$ & $\begin{array}{l}7.60 \\
7.30 \\
7.40 \\
7.75 \\
7.80 \\
7.90 \\
7.71 \\
7.80 \\
7.90 \\
7.62 \\
7.60 \\
7.70\end{array}$ & $\begin{array}{l}354 \\
177 \\
304 \\
167 \\
327 \\
340 \\
315 \\
388 \\
364 \\
301 \\
420 \\
357\end{array}$ & $\begin{array}{l}32.0 \\
24.0 \\
23.5 \\
21.0 \\
24.0 \\
24.0 \\
17.0 \\
19.5 \\
23.0 \\
17.5 \\
29.0 \\
20.0\end{array}$ & $\begin{array}{r}1.8 \\
.8 \\
.6 \\
.7 \\
.7 \\
1.2 \\
.5 \\
2.6 \\
.2 \\
.2 \\
.7 \\
.5 \\
.9\end{array}$ & $\begin{array}{l}410 \\
450 \\
460 \\
560 \\
480 \\
500 \\
470 \\
410 \\
420 \\
490 \\
410 \\
420\end{array}$ & $\begin{array}{l}300 \\
340 \\
340 \\
230 \\
260 \\
270 \\
450 \\
580 \\
590 \\
320 \\
400 \\
410\end{array}$ \\
\hline 10 & $\begin{array}{l}3 \\
6 \\
9\end{array}$ & $\begin{array}{l}8-13-86 \\
2-26-86 \\
2-25-86 \\
2-26-86\end{array}$ & $\begin{array}{l}13,200 \\
14,000 \\
20,900 \\
20,800\end{array}$ & $\begin{array}{l}7.20 \\
7.77 \\
7.79 \\
7.77\end{array}$ & $\begin{array}{l}260 \\
346 \\
343 \\
366\end{array}$ & $\begin{array}{l}22.0 \\
20.0 \\
19.5 \\
18.0\end{array}$ & $\begin{array}{r}1.4 \\
.4 \\
.4 \\
.3\end{array}$ & $\begin{array}{l}450 \\
570 \\
470 \\
470\end{array}$ & $\begin{array}{l}290 \\
210 \\
400 \\
410\end{array}$ \\
\hline 11 & $\begin{array}{r}3 \\
6 \\
12\end{array}$ & $\begin{array}{l}8-13-86 \\
2-26-86 \\
2-26-86\end{array}$ & $\begin{array}{l}16,400 \\
17,200 \\
15,400\end{array}$ & $\begin{array}{l}7.20 \\
7.75 \\
7.82\end{array}$ & $\begin{array}{l}265 \\
377 \\
373\end{array}$ & $\begin{array}{l}22.5 \\
21.0 \\
19.5\end{array}$ & $\begin{array}{l}.8 \\
.2 \\
.7\end{array}$ & $\begin{array}{l}430 \\
600 \\
530\end{array}$ & $\begin{array}{l}270 \\
200 \\
270\end{array}$ \\
\hline 12 & 3 & $\begin{array}{l}7-16-86 \\
7-29-86 \\
8-13-86 \\
7-17-86 \\
7-31-86\end{array}$ & $\begin{array}{l}18,300 \\
17,700 \\
17,900 \\
14,900 \\
22,400\end{array}$ & $\begin{array}{l}7.20 \\
7.20 \\
7.20 \\
8.80 \\
8.60\end{array}$ & $\begin{array}{r}427 \\
375 \\
279 \\
-- \\
--\end{array}$ & $\begin{array}{l}22.0 \\
24.0 \\
23.5 \\
23.0 \\
24.5\end{array}$ & $\begin{array}{l}.9 \\
.6 \\
.8\end{array}$ & $\begin{array}{l}410 \\
430 \\
480 \\
340 \\
400\end{array}$ & $\begin{array}{l}330 \\
350 \\
370 \\
120 \\
440\end{array}$ \\
\hline 13 & $\begin{array}{r}3 \\
6 \\
12\end{array}$ & $\begin{array}{l}8-14-86 \\
3-06-86 \\
4-02-87 \\
2-27-86 \\
4-02-87\end{array}$ & $\begin{array}{r}27,100 \\
19,600 \\
11,600 \\
8,130 \\
8,930\end{array}$ & $\begin{array}{l}7.30 \\
7.56 \\
7.57 \\
7.56 \\
7.38\end{array}$ & $\begin{array}{l}257 \\
378 \\
328 \\
415 \\
344\end{array}$ & $\begin{array}{l}22.5 \\
19.5 \\
19.0 \\
20.0 \\
19.5\end{array}$ & $\begin{array}{r}.7 \\
1.8 \\
2.6 \\
5.6 \\
4.7\end{array}$ & $\begin{array}{l}430 \\
540 \\
480 \\
490 \\
480\end{array}$ & $\begin{array}{l}410 \\
330 \\
330 \\
290 \\
420\end{array}$ \\
\hline 14 & $\begin{array}{l}3 \\
6 \\
8\end{array}$ & $\begin{array}{l}7-30-86 \\
8-14-86 \\
3-06-86 \\
4-02-87 \\
2-27-86 \\
4-02-87\end{array}$ & $\begin{array}{l}23,300 \\
22,000 \\
30,500 \\
36,200 \\
32,100 \\
38,500\end{array}$ & $\begin{array}{l}7.30 \\
7.30 \\
7.37 \\
7.25 \\
7.43 \\
7.32\end{array}$ & $\begin{array}{l}207 \\
268 \\
365 \\
178 \\
424 \\
412\end{array}$ & $\begin{array}{l}24.0 \\
21.5 \\
19.5 \\
19.5 \\
20.5 \\
19.5\end{array}$ & $\begin{array}{l}.5 \\
.4 \\
.8 \\
.4 \\
.5 \\
.4\end{array}$ & $\begin{array}{l}410 \\
480 \\
620 \\
620 \\
590 \\
550\end{array}$ & $\begin{array}{l}340 \\
370 \\
640 \\
780 \\
650 \\
880\end{array}$ \\
\hline 15 & $\begin{array}{r}3 \\
6 \\
12\end{array}$ & $\begin{array}{l}8-14-87 \\
3-06-86 \\
8-31-88 \\
2-27-86 \\
8-31-88\end{array}$ & $\begin{array}{r}31,200 \\
20,800 \\
23,000 \\
5,510 \\
5,950\end{array}$ & $\begin{array}{l}7.50 \\
7.50 \\
7.43 \\
7.45 \\
7.62\end{array}$ & $\begin{array}{r}-- \\
173 \\
-- \\
399 \\
--\end{array}$ & $\begin{array}{l}25.0 \\
19.0 \\
20.5 \\
20.0 \\
20.5\end{array}$ & $\begin{array}{l}- \\
2.4 \\
1.5 \\
7.0 \\
6.1\end{array}$ & $\begin{array}{l}390 \\
540 \\
600 \\
560 \\
550\end{array}$ & $\begin{array}{l}260 \\
560 \\
830 \\
330 \\
370\end{array}$ \\
\hline
\end{tabular}


isotopes of hydrogen and oxygen, and tritium--Continued

\begin{tabular}{|c|c|c|c|c|c|c|c|c|c|}
\hline \multicolumn{6}{|c|}{ Major ions, in milligrams per liter } & \multirow{2}{*}{$\begin{array}{l}\text { Carbon, } \\
\text { organic, } \\
\text { dissolved } \\
\text { (as C) }\end{array}$} & \multirow{2}{*}{$\begin{array}{c}{ }^{2} \mathrm{H} /{ }^{1} \mathrm{H} \\
\text { stable } \\
\text { isotope } \\
\text { ratio } \\
\text { (per mil) }\end{array}$} & \multirow{2}{*}{$\begin{array}{c}{ }^{18} \mathrm{O} /{ }^{16} \mathrm{O} \\
\text { stable } \\
\text { isotope } \\
\text { ratio } \\
\text { (per mil) }\end{array}$} & \multirow{2}{*}{$\begin{array}{l}\text { Tritium, } \\
\text { in water } \\
\text { molecules } \\
\text { (TU) }\end{array}$} \\
\hline $\begin{array}{l}\text { Sodium, } \\
\text { dissolved }\end{array}$ & $\begin{array}{l}\text { Potassium, } \\
\text { dissolved }\end{array}$ & $\begin{array}{l}\text { Bicarbonate, } \\
\text { whole water }\end{array}$ & $\begin{array}{l}\text { Sulfate, } \\
\text { dissolved }\end{array}$ & $\begin{array}{l}\text { Chloride, } \\
\text { dissolved }\end{array}$ & $\begin{array}{c}\text { Silica, } \\
\text { dissolved }\end{array}$ & & & & \\
\hline 1,900 & 1.8 & 160 & 5,400 & 1,400 & 24 & -- & -58.5 & -6.5 & -- \\
\hline 2,100 & 1.4 & 164 & 5,000 & 1,300 & 25 & 3.0 & -- & -- & -- \\
\hline 2,600 & 1.7 & 130 & 5,000 & 1,300 & 24 & 3.4 & -- & -- & $<0.8$ \\
\hline 3,000 & 2.2 & 142 & 5,400 & 2,100 & 27 & 5.3 & -57.0 & -5.9 & 1.4 \\
\hline 2,500 & 3.7 & 417 & 5,800 & 1,300 & 74 & 10 & -- & -- & -- \\
\hline 2,900 & 3.8 & 273 & 5,800 & 1,900 & 74 & 10 & -- & -- & 5.4 \\
\hline 2,700 & 4.8 & 299 & 5,100 & 1,900 & 76 & 8.7 & -. & -- & -- \\
\hline 2,900 & 4.1 & 182 & 5,600 & 2,600 & 31 & 12 & -54.5 & -4.8 & -- \\
\hline 3,200 & 3.8 & 189 & 5,600 & 3,000 & 29 & 11 & -- & -- & -- \\
\hline 2,300 & 3.7 & 182 & 5,600 & 3,000 & 30 & 10 & -- & -- & $<.8$ \\
\hline 4,500 & 3.9 & 215 & 9,500 & 3,900 & 31 & -- & -53.5 & -4.5 & -- \\
\hline 4,800 & 3.8 & 134 & 9,100 & 4,200 & 31 & 9.1 & -- & -- & -- \\
\hline 4,600 & 3.6 & -- & 9,000 & 4,000 & 30 & 7.7 & -- & -- & $<.8$ \\
\hline 2,400 & 2.3 & 178 & 6,500 & 1,900 & 23 & -- & -58.5 & -6.6 & -- \\
\hline 2,900 & 2.0 & 149 & 6,600 & 2,000 & 23 & 13.5 & -- & -- & -- \\
\hline 5,800 & 2.1 & 133 & 6,700 & 2,000 & 22 & 4.2 & -- & -- & $<.8$ \\
\hline 2,700 & 5.5 & 423 & 5,200 & 2,000 & 74 & 9.6 & -- & -- & -- \\
\hline 2,700 & 3.9 & 176 & 5,600 & 2,500 & 30 & -- & -55.0 & -4.8 & -- \\
\hline 4,400 & 3.6 & 168 & 10,000 & 3,500 & 30 & -. & -55.5 & -4.8 & -- \\
\hline 3,900 & 3.8 & 168 & 10,000 & 3,700 & 31 & -- & -- & -- & -- \\
\hline 3,700 & 3.7 & 575 & 5,600 & 3,300 & 80 & 15 & -- & -- & -- \\
\hline 3,400 & 4.6 & 160 & 6,400 & 3,400 & 28 & -- & -- & -- & -- \\
\hline 3,100 & 4.0 & 158 & 33,000 & 2,400 & 25 & -- & -54.5 & -5.1 & -- \\
\hline 4,100 & 4.6 & 578 & 7,000 & 3,500 & 66 & 26 & -- & -- & -- \\
\hline 2,600 & 4.5 & 635 & 6,700 & 3,200 & 70 & 23 & -- & -- & 2.8 \\
\hline 4,200 & 5.0 & 751 & 6,900 & 3,300 & 74 & 20 & -- & -- & -- \\
\hline 3,700 & 12 & 309 & 6,000 & 2,500 & 13 & 12 & -- & -- & -- \\
\hline 2,700 & 3.9 & 141 & 9,600 & 3,000 & 26 & 13 & -- & -- & 1.9 \\
\hline 6,900 & 7.3 & 947 & 11,000 & 4,400 & 53 & 28 & -- & -- & -- \\
\hline 3,300 & 4.3 & 180 & 8,000 & 2,600 & 30 & 6.7 & -56.0 & -5.5 & -- \\
\hline 2,200 & 2.0 & 140 & 5,100 & 1,500 & 55 & 3.0 & -60.0 & -6.9 & $<.8$ \\
\hline 1,300 & 1.2 & 211 & 4,700 & 890 & 44 & -- & -59.5 & -7.0 & -- \\
\hline 1,400 & 0.70 & 132 & 4,200 & 1,000 & 44 & 1.4 & -60.0 & -7.3 & $<.8$ \\
\hline 3,900 & 4.7 & 524 & 7,900 & 4,500 & 55 & 28 & -. & -- & -- \\
\hline 5,300 & 5.2 & 691 & 7,700 & 4,300 & 56 & 24 & -- & -- & -- \\
\hline 5,800 & 6.9 & 358 & 8,100 & 7,500 & 41 & 19 & -54.0 & -4.5 & -- \\
\hline 6,300 & 6.1 & 376 & 7,000 & 8,200 & 41 & 26 & -55.0 & -4.6 & $<.8$ \\
\hline 7,000 & 5.8 & 420 & 11,000 & 8,300 & 35 & -- & -51.0 & -3.4 & -- \\
\hline 6,700 & 4.9 & 312 & 8,500 & 8,400 & 35 & 19 & -52.5 & -4.1 & 3.2 \\
\hline 2,800 & 3.8 & 383 & 7,400 & 720 & 42 & 10 & -- & -- & -- \\
\hline 3,900 & 4.0 & 200 & 7,700 & 3,800 & 35 & -- & -56.0 & -5.7 & -- \\
\hline 4,400 & 3.6 & 188 & 7,100 & 4,200 & 32 & 11 & -57.5 & -5.7 & $<.8$ \\
\hline 1,000 & 1.2 & 150 & 3,700 & 1,200 & 36 & -- & -60.0 & -6.9 & -- \\
\hline 1,200 & 1.1 & 102 & 3,600 & 1,200 & 38 & 2.2 & -61.0 & -6.9 & 1.4 \\
\hline
\end{tabular}


Table 4. Chemical analysis of dissolved trace elements

[Cluster site: Site at which one to five observation wells were installed at different depths. Well depth: Depth, in meters below land surface, of each observation well completed at cluster site. Concentrations of trace elements in micrograms per liter. --, no data; $<$, actual value is less than value shown]

\begin{tabular}{|c|c|c|c|c|c|c|c|c|c|c|c|c|c|}
\hline $\begin{array}{l}\text { Cluster } \\
\text { site }\end{array}$ & $\begin{array}{l}\text { Well } \\
\text { depth }\end{array}$ & Date & $\begin{array}{c}\text { Alumi- } \\
\text { num }\end{array}$ & Arsenic & Boron & $\begin{array}{l}\text { Chro- } \\
\text { mium }\end{array}$ & Iron & Lithium & $\begin{array}{c}\text { Manga- } \\
\text { nese }\end{array}$ & $\begin{array}{l}\text { Molyb- } \\
\text { denum }\end{array}$ & Nickel & $\begin{array}{l}\text { Sele- } \\
\text { nium }\end{array}$ & $\begin{array}{l}\text { Vana- } \\
\text { dium }\end{array}$ \\
\hline EW1 & 4 & $\begin{array}{l}2-04-86 \\
7-17-86 \\
7-30-86\end{array}$ & $\begin{array}{l}20 \\
20 \\
20\end{array}$ & $\begin{array}{l}2 \\
2 \\
2\end{array}$ & $\begin{array}{l}10,000 \\
11,000 \\
11,000\end{array}$ & $\begin{array}{l}20 \\
30 \\
30\end{array}$ & $\begin{array}{l}70 \\
60 \\
40\end{array}$ & $\begin{array}{l}-- \\
470 \\
500\end{array}$ & $\begin{array}{l}30 \\
20 \\
30\end{array}$ & $\begin{array}{l}24 \\
25 \\
17\end{array}$ & $\begin{array}{l}8 \\
-- \\
--\end{array}$ & $\begin{array}{r}1,000 \\
510 \\
390\end{array}$ & $\begin{array}{r}38 \\
<20 \\
<20\end{array}$ \\
\hline EW2 & 4 & $2-04-86$ & 30 & 2 & 18,000 & 10 & 80 & -- & 200 & 36 & 35 & 860 & 30 \\
\hline EW3 & 4 & $2-04-86$ & 20 & 2 & 15,000 & 10 & 70 & - & 30 & 48 & 20 & 1,100 & 40 \\
\hline EW4 & 4 & $\begin{array}{l}7-17-86 \\
7-30-86\end{array}$ & $\begin{array}{l}10 \\
10\end{array}$ & $\begin{array}{l}2 \\
2\end{array}$ & $\begin{array}{l}30,000 \\
24,000\end{array}$ & $\begin{array}{l}30 \\
30\end{array}$ & $\begin{array}{l}90 \\
60\end{array}$ & $\begin{array}{l}460 \\
410\end{array}$ & $\begin{array}{l}40 \\
30\end{array}$ & $\begin{array}{l}16 \\
10\end{array}$ & $\begin{array}{l}-- \\
--\end{array}$ & $\begin{array}{l}2,200 \\
2,000\end{array}$ & $\begin{array}{l}<40 \\
<30\end{array}$ \\
\hline EW5 & 4 & $\begin{array}{l}7-17-86 \\
7-30-86\end{array}$ & $\begin{array}{r}10 \\
<10\end{array}$ & $\begin{array}{l}2 \\
2\end{array}$ & $\begin{array}{l}37,000 \\
36,000\end{array}$ & $\begin{array}{l}20 \\
20\end{array}$ & $\begin{array}{l}90 \\
50\end{array}$ & $\begin{array}{l}480 \\
500\end{array}$ & $\begin{array}{l}30 \\
40\end{array}$ & $\begin{array}{l}57 \\
38\end{array}$ & -- & $\begin{array}{l}1,900 \\
1,800\end{array}$ & $\begin{array}{l}<40 \\
<40\end{array}$ \\
\hline EW6 & 4 & $\begin{array}{l}7-17-86 \\
7-30-86\end{array}$ & $\begin{array}{r}20 \\
<10\end{array}$ & $\begin{array}{l}2 \\
2\end{array}$ & $\begin{array}{r}5,700 \\
11,000\end{array}$ & $\begin{array}{r}<10 \\
20\end{array}$ & $\begin{array}{l}50 \\
20\end{array}$ & $\begin{array}{l}210 \\
220\end{array}$ & $\begin{array}{r}40 \\
120\end{array}$ & $\begin{array}{l}150 \\
140\end{array}$ & -- & $\begin{array}{l}19 \\
39\end{array}$ & $\begin{array}{l}7 \\
5\end{array}$ \\
\hline MA & 15 & $6-30-87$ & 10 & 2 & 27,000 & 50 & 40 & 330 & 20 & 74 & 1 & 300 & 17 \\
\hline MB & 15 & $3-31-87$ & $<10$ & -- & 9,500 & 30 & 30 & 290 & 40 & 64 & 1 & 840 & $<60$ \\
\hline MBS & 9 & $\begin{array}{l}4-01-87 \\
9-01-88\end{array}$ & $\begin{array}{l}10 \\
20\end{array}$ & $\begin{array}{l}-- \\
--\end{array}$ & $\begin{array}{l}29,000 \\
29,000\end{array}$ & $\begin{array}{l}20 \\
30\end{array}$ & $\begin{array}{l}60 \\
60\end{array}$ & $\begin{array}{l}280 \\
320\end{array}$ & $\begin{array}{l}30 \\
30\end{array}$ & $\begin{array}{r}130 \\
78\end{array}$ & $\begin{array}{l}7 \\
7\end{array}$ & $\begin{array}{l}3,900 \\
4,600\end{array}$ & $\begin{array}{r}<60 \\
93\end{array}$ \\
\hline MCS & 9 & $4-01-87$ & 20 & - & 29,000 & 20 & 80 & 290 & 30 & 140 & - & 3,800 & $<60$ \\
\hline MDS & 8 & $4-01-87$ & $<10$ & -- & 32,000 & 20 & 60 & 300 & 30 & 160 & 8 & 4,100 & $<60$ \\
\hline MF & $\begin{array}{l}3.5 \\
6 \\
9\end{array}$ & $\begin{array}{l}10-22-87 \\
10-22-87 \\
10-22-87\end{array}$ & $\begin{array}{r}20 \\
<10 \\
<10\end{array}$ & $\begin{array}{l}-- \\
-- \\
-\end{array}$ & $\begin{array}{r}5,900 \\
1,900 \\
13,000\end{array}$ & $\begin{array}{r}3 \\
2 \\
40\end{array}$ & $\begin{array}{l}40 \\
20 \\
50\end{array}$ & $\begin{array}{l}280 \\
150 \\
240\end{array}$ & $\begin{array}{r}220 \\
480 \\
20\end{array}$ & $\begin{array}{r}79 \\
99 \\
120\end{array}$ & $\begin{array}{r}10 \\
6 \\
9\end{array}$ & $\begin{array}{r}5 \\
6 \\
570\end{array}$ & $\begin{array}{r}10 \\
5 \\
18\end{array}$ \\
\hline M1 & $\begin{array}{r}3 \\
6 \\
9 \\
12 \\
15\end{array}$ & $\begin{array}{l}6-11-87 \\
7-20-88 \\
6-11-87 \\
7-20-88 \\
6-11-87 \\
7-01-87 \\
6-11-87\end{array}$ & $\begin{array}{r}10 \\
<10 \\
10 \\
20 \\
<10 \\
20 \\
20\end{array}$ & $\begin{array}{l}4 \\
-- \\
4 \\
-- \\
4 \\
3 \\
2\end{array}$ & $\begin{array}{l}15,000 \\
12,000 \\
16,000 \\
14,000 \\
27,000 \\
11,000 \\
15,000\end{array}$ & $\begin{array}{r}<1 \\
9 \\
<1 \\
8 \\
<1 \\
5 \\
40\end{array}$ & $\begin{array}{l}40 \\
40 \\
50 \\
50 \\
60 \\
70 \\
50\end{array}$ & $\begin{array}{l}280 \\
320 \\
190 \\
180 \\
250 \\
360 \\
350\end{array}$ & $\begin{array}{r}20 \\
30 \\
20 \\
30 \\
20 \\
20 \\
<10\end{array}$ & $\begin{array}{r}31 \\
30 \\
83 \\
76 \\
150 \\
170 \\
130\end{array}$ & $\begin{array}{r}5 \\
8 \\
<1 \\
3 \\
3 \\
1 \\
6\end{array}$ & $\begin{array}{r}310 \\
27 \\
11 \\
25 \\
220 \\
260 \\
1,000\end{array}$ & $\begin{array}{l}16 \\
20 \\
10 \\
11 \\
11 \\
45 \\
21\end{array}$ \\
\hline M4 & $\begin{array}{r}6 \\
9 \\
15\end{array}$ & $\begin{array}{l}6-10-87 \\
7-22-88 \\
6-10-87 \\
7-20-88 \\
6-10-87 \\
7-20-88\end{array}$ & $\begin{array}{l}10 \\
20 \\
10 \\
20 \\
10 \\
20\end{array}$ & $\begin{array}{c}5 \\
-- \\
4 \\
-- \\
3 \\
--\end{array}$ & $\begin{array}{l}39,000 \\
37,000 \\
28,000 \\
25,000 \\
17,000 \\
17,000\end{array}$ & $\begin{array}{r}<1 \\
6 \\
8 \\
20 \\
20 \\
20\end{array}$ & $\begin{array}{l}70 \\
80 \\
60 \\
70 \\
30 \\
50\end{array}$ & $\begin{array}{l}190 \\
220 \\
330 \\
300 \\
350 \\
350\end{array}$ & $\begin{array}{l}70 \\
80 \\
20 \\
30 \\
30 \\
30\end{array}$ & $\begin{array}{r}74 \\
100 \\
120 \\
160 \\
72 \\
80\end{array}$ & $\begin{array}{r}5 \\
5 \\
1 \\
397 \\
1 \\
2\end{array}$ & $\begin{array}{r}4,100 \\
3,100 \\
190 \\
970 \\
330 \\
340\end{array}$ & $\begin{array}{l}28 \\
80 \\
22 \\
33 \\
13 \\
20\end{array}$ \\
\hline M5 & $\begin{array}{l}12 \\
15\end{array}$ & $\begin{array}{l}6-09-87 \\
7-21-88 \\
6-09-87 \\
7-21-88 \\
7-01-87 \\
7-21-88 \\
6-09-87 \\
7-21-88\end{array}$ & $\begin{array}{r}10 \\
20 \\
<10 \\
10 \\
<10 \\
<10 \\
<10 \\
10\end{array}$ & $\begin{array}{c}4 \\
-- \\
3 \\
-- \\
2 \\
-- \\
-- \\
--\end{array}$ & $\begin{array}{l}16,000 \\
13,000 \\
24,000 \\
22,000 \\
12,000 \\
11,000 \\
17,000 \\
15,000\end{array}$ & $\begin{array}{r}5 \\
10 \\
<1 \\
20 \\
<1 \\
20 \\
<1 \\
10\end{array}$ & $\begin{array}{l}50 \\
40 \\
60 \\
60 \\
50 \\
40 \\
60 \\
40\end{array}$ & $\begin{array}{l}200 \\
200 \\
360 \\
250 \\
230 \\
230 \\
260 \\
300\end{array}$ & $\begin{array}{l}20 \\
40 \\
20 \\
20 \\
20 \\
20 \\
20 \\
20\end{array}$ & $\begin{array}{r}67 \\
64 \\
110 \\
160 \\
87 \\
76 \\
140 \\
150\end{array}$ & $\begin{array}{r}1 \\
4 \\
<1 \\
2 \\
2 \\
4 \\
<1 \\
3\end{array}$ & $\begin{array}{l}820 \\
500 \\
520 \\
240 \\
200 \\
170 \\
200 \\
110\end{array}$ & $\begin{array}{l}35 \\
33 \\
16 \\
25 \\
18 \\
17 \\
23 \\
20\end{array}$ \\
\hline
\end{tabular}


Table 4. Chemical analysis of dissolved trace elements--Continued

\begin{tabular}{|c|c|c|c|c|c|c|c|c|c|c|c|c|c|}
\hline $\begin{array}{l}\text { Cluster } \\
\text { site }\end{array}$ & $\begin{array}{l}\text { Well } \\
\text { depth }\end{array}$ & Date & $\begin{array}{c}\text { Alumi- } \\
\text { num }\end{array}$ & Arsenic & Boron & $\begin{array}{l}\text { Chro- } \\
\text { mium }\end{array}$ & Iron & Lithium & $\begin{array}{l}\text { Manga- } \\
\text { nese }\end{array}$ & $\begin{array}{l}\text { Molyb- } \\
\text { denum }\end{array}$ & Nickel & $\begin{array}{l}\text { Sele- } \\
\text { nium }\end{array}$ & $\begin{array}{l}\text { Vana- } \\
\text { dium }\end{array}$ \\
\hline M8 & $\begin{array}{r}3 \\
6 \\
12 \\
15\end{array}$ & $\begin{array}{l}10-20-87 \\
10-20-87 \\
10-20-87 \\
10-20-87\end{array}$ & $\begin{array}{r}<10 \\
10 \\
20 \\
<10\end{array}$ & $\begin{array}{l}-- \\
-- \\
-- \\
--\end{array}$ & $\begin{array}{r}3,700 \\
12,000 \\
11,000 \\
14,000\end{array}$ & $\begin{array}{l}50 \\
30 \\
30 \\
90\end{array}$ & $\begin{array}{l}20 \\
30 \\
40 \\
40\end{array}$ & $\begin{array}{l}180 \\
310 \\
240 \\
280\end{array}$ & $\begin{array}{l}90 \\
50 \\
20 \\
30\end{array}$ & $\begin{array}{r}20 \\
21 \\
41 \\
110\end{array}$ & $\begin{array}{r}9 \\
10 \\
<1 \\
6\end{array}$ & $\begin{array}{r}50 \\
180 \\
410 \\
410\end{array}$ & $\begin{array}{l}12 \\
13 \\
10 \\
13\end{array}$ \\
\hline M10 & $\begin{array}{r}3 \\
6 \\
12 \\
15\end{array}$ & $\begin{array}{l}10-21-87 \\
10-21-87 \\
10-21-87 \\
10-21-87\end{array}$ & $\begin{array}{l}20 \\
20 \\
30 \\
20\end{array}$ & $\begin{array}{l}-- \\
-- \\
-- \\
--\end{array}$ & $\begin{array}{r}5,200 \\
17,000 \\
16,000 \\
22,000\end{array}$ & $\begin{array}{r}4 \\
4 \\
20 \\
40\end{array}$ & $\begin{array}{l}20 \\
30 \\
40 \\
50\end{array}$ & $\begin{array}{r}11 \\
240 \\
240 \\
300\end{array}$ & $\begin{array}{l}90 \\
30 \\
20 \\
30\end{array}$ & $\begin{array}{l}11 \\
67 \\
83 \\
95\end{array}$ & $\begin{array}{r}2 \\
8 \\
<1 \\
<1\end{array}$ & $\begin{array}{r}33 \\
120 \\
420 \\
2,100\end{array}$ & $\begin{array}{l}12 \\
15 \\
18 \\
31\end{array}$ \\
\hline NW1 & 4 & $2-04-86$ & 10 & 1 & 10,000 & $<1$ & 40 & -- & 50 & 28 & 8 & 82 & 18 \\
\hline NW4 & 4 & $2-04-86$ & 30 & 2 & 8,500 & 10 & 60 & -- & 120 & 21 & 6 & 160 & 16 \\
\hline NW7 & 4 & $2-03-86$ & $<10$ & 2 & 8,700 & 4 & 60 & -- & 20 & 18 & 1 & 27 & 14 \\
\hline NW10 & 4 & $\begin{array}{l}1-31-86 \\
7-22-88\end{array}$ & $\begin{array}{l}20 \\
10\end{array}$ & $\begin{array}{l}4 \\
--\end{array}$ & $\begin{array}{r}29,000 \\
9,500\end{array}$ & $\begin{array}{l}<1 \\
20\end{array}$ & $\begin{array}{l}70 \\
40\end{array}$ & 250 & $\begin{array}{l}20 \\
20\end{array}$ & $\begin{array}{l}42 \\
18\end{array}$ & $\begin{array}{l}4 \\
3\end{array}$ & $\begin{array}{l}370 \\
160\end{array}$ & $\begin{array}{l}28 \\
22\end{array}$ \\
\hline NW13 & 4 & $2-04-86$ & 20 & 2 & 25,000 & $<1$ & 50 & -- & 80 & 62 & 15 & 68 & 42 \\
\hline SE1 & 4 & $\begin{array}{l}2-05-86 \\
5-23-86 \\
7-16-86 \\
7-29-86\end{array}$ & $\begin{array}{l}90 \\
20 \\
10 \\
20\end{array}$ & $\begin{array}{l}3 \\
3 \\
3 \\
3\end{array}$ & $\begin{array}{l}30,000 \\
30,000 \\
31,000 \\
31,000\end{array}$ & $\begin{array}{r}4 \\
8 \\
20 \\
30\end{array}$ & $\begin{array}{r}240 \\
80 \\
50 \\
80\end{array}$ & $\begin{array}{l}-- \\
480 \\
490 \\
500\end{array}$ & $\begin{array}{l}240 \\
270 \\
210 \\
220\end{array}$ & $\begin{array}{l}30 \\
29 \\
25 \\
34\end{array}$ & $\begin{array}{c}24 \\
22 \\
-- \\
--\end{array}$ & $\begin{array}{l}330 \\
320 \\
290 \\
370\end{array}$ & $\begin{array}{r}80 \\
60 \\
90 \\
<30\end{array}$ \\
\hline SE4 & 4 & $\begin{array}{l}2-05-86 \\
5-22-86 \\
7-15-86 \\
7-29-86\end{array}$ & $\begin{array}{r}40 \\
10 \\
<10 \\
20\end{array}$ & $\begin{array}{l}2 \\
3 \\
3 \\
3\end{array}$ & $\begin{array}{l}16,000 \\
13,000 \\
17,000 \\
17,000\end{array}$ & $\begin{array}{l}10 \\
20 \\
20 \\
30\end{array}$ & $\begin{array}{l}90 \\
60 \\
50 \\
60\end{array}$ & $\begin{array}{l}280 \\
300 \\
290\end{array}$ & $\begin{array}{l}20 \\
20 \\
20 \\
20\end{array}$ & $\begin{array}{l}38 \\
26 \\
40 \\
51\end{array}$ & $\begin{array}{r}13 \\
6 \\
-- \\
--\end{array}$ & $\begin{array}{r}1,300 \\
540 \\
1,000 \\
1,100\end{array}$ & $\begin{array}{r}56 \\
29 \\
<20 \\
<20\end{array}$ \\
\hline SE7 & 4 & $\begin{array}{l}2-05-86 \\
5-21-86 \\
7-16-86 \\
7-29-86\end{array}$ & $\begin{array}{r}20 \\
<10 \\
<10 \\
<10\end{array}$ & $\begin{array}{l}3 \\
3 \\
3 \\
3\end{array}$ & $\begin{array}{l}37,000 \\
37,000 \\
39,000 \\
37,000\end{array}$ & $\begin{array}{r}1 \\
2 \\
20 \\
30\end{array}$ & $\begin{array}{r}70 \\
100 \\
80 \\
90\end{array}$ & $\begin{array}{r}-- \\
410 \\
420 \\
430\end{array}$ & $\begin{array}{l}30 \\
30 \\
30 \\
30\end{array}$ & $\begin{array}{l}160 \\
110 \\
140 \\
130\end{array}$ & $\begin{array}{c}8 \\
6 \\
-- \\
--\end{array}$ & $\begin{array}{l}4,400 \\
3,900 \\
4,400 \\
4,100\end{array}$ & $\begin{array}{r}65 \\
150 \\
<60 \\
<60\end{array}$ \\
\hline SE10 & 4 & $\begin{array}{l}2-05-86 \\
5-21-86 \\
7-31-86 \\
9-01-88\end{array}$ & $\begin{array}{l}20 \\
30 \\
20 \\
10\end{array}$ & $\begin{array}{l}2 \\
2 \\
4 \\
--\end{array}$ & $\begin{array}{l}35,000 \\
22,000 \\
20,000 \\
24,000\end{array}$ & $\begin{array}{r}5 \\
5 \\
150 \\
<1\end{array}$ & $\begin{array}{l}80 \\
60 \\
80 \\
40\end{array}$ & $\begin{array}{l}-- \\
390 \\
400 \\
380\end{array}$ & $\begin{array}{l}30 \\
20 \\
20 \\
10\end{array}$ & $\begin{array}{l}24 \\
24 \\
30 \\
30\end{array}$ & $\begin{array}{c}7 \\
5 \\
-- \\
4\end{array}$ & $\begin{array}{r}3,000 \\
630 \\
620 \\
990\end{array}$ & $\begin{array}{r}85 \\
41 \\
<10 \\
12\end{array}$ \\
\hline SE13 & 4 & $\begin{array}{l}2-05-86 \\
5-21-86\end{array}$ & $\begin{array}{r}20 \\
140\end{array}$ & $\begin{array}{l}1 \\
1\end{array}$ & $\begin{array}{l}29,000 \\
28,000\end{array}$ & $\begin{array}{l}6 \\
4\end{array}$ & $\begin{array}{r}70 \\
260\end{array}$ & 480 & $\begin{array}{l}30 \\
40\end{array}$ & $\begin{array}{l}10 \\
11\end{array}$ & $\begin{array}{l}11 \\
15\end{array}$ & $\begin{array}{l}2,000 \\
2,600\end{array}$ & $\begin{array}{l}82 \\
75\end{array}$ \\
\hline 1 & $\begin{array}{r}6 \\
9 \\
12\end{array}$ & $\begin{array}{l}7-30-86 \\
8-12-86 \\
8-30-88 \\
3-05-86 \\
8-30-88 \\
3-05-86 \\
3-05-86\end{array}$ & $\begin{array}{l}20 \\
10 \\
20 \\
20 \\
10 \\
20 \\
20\end{array}$ & $\begin{array}{c}2 \\
2 \\
-- \\
2 \\
-- \\
3 \\
1\end{array}$ & $\begin{array}{l}24,000 \\
24,000 \\
14,000 \\
26,000 \\
23,000 \\
24,000 \\
16,000\end{array}$ & $\begin{array}{l}40 \\
30 \\
10 \\
20 \\
40 \\
50 \\
50\end{array}$ & $\begin{array}{r}100 \\
70 \\
50 \\
80 \\
30 \\
70 \\
50\end{array}$ & $\begin{array}{r}330 \\
340 \\
280 \\
-- \\
240 \\
-- \\
--\end{array}$ & $\begin{array}{l}20 \\
20 \\
30 \\
30 \\
50 \\
20 \\
30\end{array}$ & $\begin{array}{r}24 \\
24 \\
19 \\
72 \\
76 \\
240 \\
1,500\end{array}$ & $\begin{array}{l}-. \\
-- \\
4 \\
6 \\
6 \\
1 \\
2\end{array}$ & $\begin{array}{r}1,100 \\
1,100 \\
480 \\
2,200 \\
1,200 \\
1,200 \\
1,100\end{array}$ & $\begin{array}{r}<20 \\
10 \\
35 \\
56 \\
13 \\
34 \\
52\end{array}$ \\
\hline 2 & 3 & $\begin{array}{l}5-23-86 \\
7-30-86 \\
9-01-88\end{array}$ & $\begin{array}{l}20 \\
20 \\
20\end{array}$ & $\begin{array}{l}2 \\
2 \\
--\end{array}$ & $\begin{array}{l}32,000 \\
35,000 \\
39,000\end{array}$ & $\begin{array}{l}20 \\
40 \\
30\end{array}$ & $\begin{array}{r}100 \\
80 \\
70\end{array}$ & $\begin{array}{l}560 \\
590 \\
490\end{array}$ & $\begin{array}{r}40 \\
50 \\
140\end{array}$ & $\begin{array}{l}12 \\
14 \\
14\end{array}$ & $\begin{array}{l}13 \\
-- \\
17\end{array}$ & $\begin{array}{l}430 \\
690 \\
970\end{array}$ & $\begin{array}{l}110 \\
<50 \\
210\end{array}$ \\
\hline
\end{tabular}


Table 4. Chemical analysis of dissolved trace elements--Continued

\begin{tabular}{|c|c|c|c|c|c|c|c|c|c|c|c|c|c|}
\hline $\begin{array}{l}\text { Cluster } \\
\text { site }\end{array}$ & $\begin{array}{l}\text { Well } \\
\text { depth }\end{array}$ & Date & $\begin{array}{c}\text { Alumi- } \\
\text { num }\end{array}$ & Arsenic & Boron & $\begin{array}{l}\text { Chro- } \\
\text { mium }\end{array}$ & Iron & Lithium & $\begin{array}{l}\text { Manga- } \\
\text { nese }\end{array}$ & $\begin{array}{l}\text { Molyb- } \\
\text { denum }\end{array}$ & Nickel & $\begin{array}{l}\text { Sele- } \\
\text { nium }\end{array}$ & $\begin{array}{l}\text { Vana- } \\
\text { dium }\end{array}$ \\
\hline 2 & 12 & $\begin{array}{l}2-28-86 \\
9-01-88\end{array}$ & $\begin{array}{l}10 \\
20\end{array}$ & $\begin{array}{c}1 \\
--\end{array}$ & $\begin{array}{l}7,400 \\
7,300\end{array}$ & $\begin{array}{l}30 \\
50\end{array}$ & $\begin{array}{l}80 \\
40\end{array}$ & 290 & $\begin{array}{l}40 \\
10\end{array}$ & $\begin{array}{l}77 \\
62\end{array}$ & $\begin{array}{l}1 \\
4\end{array}$ & $\begin{array}{l}800 \\
700\end{array}$ & $\begin{array}{l}28 \\
26\end{array}$ \\
\hline 3 & $\begin{array}{l}3 \\
6 \\
9\end{array}$ & $\begin{array}{l}7-31-86 \\
8-12-86 \\
2-06-86 \\
2-06-86\end{array}$ & $\begin{array}{l}40 \\
20 \\
30 \\
30\end{array}$ & $\begin{array}{l}4 \\
3 \\
3 \\
4\end{array}$ & $\begin{array}{l}22,000 \\
22,000 \\
23,000 \\
31,000\end{array}$ & $\begin{array}{l}10 \\
10 \\
50 \\
20\end{array}$ & $\begin{array}{r}80 \\
70 \\
80 \\
100\end{array}$ & $\begin{array}{r}530 \\
520 \\
-- \\
--\end{array}$ & $\begin{array}{r}600 \\
610 \\
20 \\
30\end{array}$ & $\begin{array}{r}56 \\
53 \\
82 \\
160\end{array}$ & $\begin{array}{l}-- \\
-- \\
3 \\
4\end{array}$ & $\begin{array}{r}280 \\
320 \\
2,200 \\
4,600\end{array}$ & $\begin{array}{r}<20 \\
<20 \\
42 \\
21\end{array}$ \\
\hline 4 & 12 & $\begin{array}{l}5-22-86 \\
7-16-86 \\
7-29-86 \\
8-12-86 \\
2-06-86 \\
7-16-86 \\
7-29-86 \\
2-06-86 \\
7-16-86 \\
7-29-86\end{array}$ & $\begin{array}{r}20 \\
230 \\
10 \\
30 \\
20 \\
10 \\
10 \\
30 \\
<10 \\
20\end{array}$ & $\begin{array}{l}5 \\
5 \\
3 \\
3 \\
3 \\
3 \\
3 \\
2 \\
2 \\
2\end{array}$ & $\begin{array}{l}16,000 \\
17,000 \\
18,000 \\
20,000 \\
26,000 \\
26,000 \\
25,000 \\
11,000 \\
11,000 \\
11,000\end{array}$ & $\begin{array}{l}20 \\
40 \\
30 \\
30 \\
20 \\
-. \\
50 \\
40 \\
50 \\
50\end{array}$ & $\begin{array}{r}70 \\
50 \\
70 \\
110 \\
70 \\
40 \\
80 \\
80 \\
50 \\
70\end{array}$ & $\begin{array}{r}470 \\
490 \\
490 \\
420 \\
-- \\
290 \\
280 \\
-- \\
290 \\
290\end{array}$ & $\begin{array}{l}50 \\
30 \\
30 \\
30 \\
20 \\
20 \\
30 \\
20 \\
20 \\
20\end{array}$ & $\begin{array}{r}26 \\
22 \\
26 \\
25 \\
110 \\
100 \\
100 \\
100 \\
120 \\
120\end{array}$ & $\begin{array}{c}9 \\
-- \\
-- \\
-- \\
1 \\
-- \\
-- \\
<1 \\
-- \\
--\end{array}$ & $\begin{array}{r}860 \\
950 \\
960 \\
1,000 \\
3,000 \\
2,900 \\
2,400 \\
1,100 \\
860 \\
1,100\end{array}$ & $\begin{array}{r}r \\
<20 \\
<20 \\
<20 \\
77 \\
<30 \\
<30 \\
44 \\
<20 \\
<20\end{array}$ \\
\hline 5 & $\begin{array}{l}3 \\
6 \\
9\end{array}$ & & $\begin{array}{r}20 \\
630 \\
20\end{array}$ & $\begin{array}{l}3 \\
4 \\
2\end{array}$ & $\begin{array}{l}21,000 \\
21,000 \\
27,000\end{array}$ & $\begin{array}{l}40 \\
20 \\
40\end{array}$ & $\begin{array}{r}80 \\
1,200 \\
100\end{array}$ & $\begin{array}{r}210 \\
-- \\
--\end{array}$ & $\begin{array}{l}20 \\
40 \\
30\end{array}$ & $\begin{array}{r}65 \\
64 \\
160\end{array}$ & $\overline{1}$ & $\begin{array}{l}2,000 \\
2,200 \\
6,300\end{array}$ & $\begin{array}{r}<25 \\
58 \\
150\end{array}$ \\
\hline 6 & $\begin{array}{r}3 \\
12\end{array}$ & $\begin{array}{l}8-13-86 \\
2-07-86\end{array}$ & $\begin{array}{l}20 \\
50\end{array}$ & $\begin{array}{l}9 \\
1\end{array}$ & $\begin{array}{l}19,000 \\
11,000\end{array}$ & $\begin{array}{l}20 \\
30\end{array}$ & $\begin{array}{r}70 \\
100\end{array}$ & $\begin{array}{r}450 \\
--\end{array}$ & $\begin{array}{r}100 \\
50\end{array}$ & $\begin{array}{l}20 \\
52\end{array}$ & $\ddot{1}$ & $\begin{array}{l}1,100 \\
1,300\end{array}$ & $\begin{array}{r}<25 \\
44\end{array}$ \\
\hline 7 & 12 & $\begin{array}{l}5-22-86 \\
7-15-86 \\
7-28-86 \\
8-12-86 \\
8-30-88 \\
3-06-86 \\
7-15-86 \\
7-29-86 \\
8-30-88 \\
2-11-86 \\
7-15-86 \\
7-29-86 \\
8-30-88 \\
2-11-86 \\
7-15-86 \\
7-28-86 \\
8-30-88\end{array}$ & $\begin{array}{r}10 \\
20 \\
10 \\
20 \\
20 \\
10 \\
20 \\
10 \\
20 \\
20 \\
20 \\
10 \\
30 \\
20 \\
<10 \\
<10 \\
10\end{array}$ & $\begin{array}{c}3 \\
3 \\
3 \\
3 \\
- \\
3 \\
3 \\
3 \\
- \\
3 \\
3 \\
3 \\
- \\
<1 \\
21 \\
<1 \\
--\end{array}$ & $\begin{array}{l}14,000 \\
16,000 \\
16,000 \\
18,000 \\
14,000 \\
22,000 \\
23,000 \\
23,000 \\
21,000 \\
26,000 \\
25,000 \\
25,000 \\
22,000 \\
13,000 \\
13,000 \\
12,000 \\
15,000\end{array}$ & $\begin{array}{r}7 \\
20 \\
10 \\
20 \\
7 \\
20 \\
30 \\
60 \\
20 \\
40 \\
50 \\
50 \\
60 \\
30 \\
60 \\
50 \\
40\end{array}$ & $\begin{array}{r}60 \\
70 \\
20 \\
70 \\
70 \\
70 \\
7 \\
80 \\
90 \\
80 \\
80 \\
60 \\
40 \\
60 \\
50\end{array}$ & $\begin{array}{r}410 \\
430 \\
440 \\
390 \\
480 \\
-- \\
260 \\
270 \\
280 \\
-- \\
360 \\
350 \\
300 \\
-- \\
290 \\
280 \\
270\end{array}$ & $\begin{array}{r}20 \\
20 \\
20 \\
40 \\
140 \\
20 \\
20 \\
20 \\
1 \\
20 \\
20 \\
20 \\
30 \\
20 \\
20 \\
20 \\
20\end{array}$ & $\begin{array}{r}14 \\
12 \\
16 \\
17 \\
12 \\
80 \\
55 \\
70 \\
62 \\
150 \\
150 \\
150 \\
120 \\
110 \\
130 \\
130 \\
100\end{array}$ & $\begin{array}{c}5 \\
-- \\
-- \\
-- \\
7 \\
1 \\
-- \\
-- \\
2 \\
<1 \\
-- \\
-- \\
2 \\
4 \\
-- \\
-- \\
2\end{array}$ & $\begin{array}{r}890 \\
1,100 \\
970 \\
960 \\
1,100 \\
2,500 \\
2,500 \\
2,300 \\
1,700 \\
5,500 \\
4,400 \\
4,400 \\
4,000 \\
1,500 \\
1,200 \\
1,000 \\
1,900\end{array}$ & $\begin{array}{r}20 \\
<20 \\
20 \\
<15 \\
23 \\
17 \\
<30 \\
<30 \\
26 \\
51 \\
<50 \\
<50 \\
61 \\
51 \\
<20 \\
<20 \\
21\end{array}$ \\
\hline 9 & 3 & $\begin{array}{l}7-15-86 \\
7-28-86 \\
8-13-86 \\
3-06-86 \\
7-16-86 \\
7-28-86 \\
2-11-86 \\
7-16-86 \\
7-28-86\end{array}$ & $\begin{array}{r}10 \\
<10 \\
20 \\
10 \\
10 \\
30 \\
20 \\
<10 \\
10\end{array}$ & $\begin{array}{l}3 \\
3 \\
3 \\
4 \\
4 \\
4 \\
3 \\
3 \\
3\end{array}$ & $\begin{array}{l}17,000 \\
18,000 \\
19,000 \\
23,000 \\
24,000 \\
24,000 \\
25,000 \\
25,000 \\
26,000\end{array}$ & $\begin{array}{l}30 \\
20 \\
20 \\
20 \\
60 \\
30 \\
40 \\
70 \\
70\end{array}$ & $\begin{array}{l}60 \\
50 \\
80 \\
60 \\
70 \\
80 \\
80 \\
80 \\
80\end{array}$ & $\begin{array}{r}350 \\
360 \\
320 \\
- \\
240 \\
230 \\
-- \\
350 \\
330\end{array}$ & $\begin{array}{l}20 \\
20 \\
20 \\
20 \\
20 \\
20 \\
20 \\
20 \\
20\end{array}$ & $\begin{array}{r}28 \\
27 \\
28 \\
66 \\
66 \\
69 \\
160 \\
140 \\
140\end{array}$ & $\begin{array}{l}-- \\
-- \\
-- \\
2 \\
-- \\
-- \\
1 \\
-- \\
--\end{array}$ & $\begin{array}{r}910 \\
1,200 \\
1,500 \\
2,500 \\
2,400 \\
2,200 \\
5,600 \\
4,500 \\
4,300\end{array}$ & $\begin{array}{r}<20 \\
<20 \\
<20 \\
79 \\
<30 \\
<30 \\
130 \\
<50 \\
<40\end{array}$ \\
\hline
\end{tabular}


Table 4. Chemical analysis of dissolved trace elements--Continued

\begin{tabular}{|c|c|c|c|c|c|c|c|c|c|c|c|c|c|}
\hline $\begin{array}{l}\text { Cluster } \\
\text { site }\end{array}$ & $\begin{array}{l}\text { Well } \\
\text { depth }\end{array}$ & Date & $\begin{array}{l}\text { Alumi- } \\
\text { num }\end{array}$ & Arsenic & Boron & $\begin{array}{l}\text { Chro- } \\
\text { mium }\end{array}$ & Iron & Lithium & $\begin{array}{l}\text { Manga- } \\
\text { nese }\end{array}$ & $\begin{array}{l}\text { Molyb- } \\
\text { denum }\end{array}$ & Nickel & $\begin{array}{l}\text { Sele- } \\
\text { nium }\end{array}$ & $\begin{array}{l}\text { Vana- } \\
\text { dium }\end{array}$ \\
\hline 9 & 12 & $\begin{array}{l}2-28-86 \\
7-15-86 \\
7-29-86\end{array}$ & $\begin{array}{l}10 \\
10 \\
20\end{array}$ & $\begin{array}{r}1 \\
<1 \\
<1\end{array}$ & $\begin{array}{l}15,000 \\
16,000 \\
16,000\end{array}$ & $\begin{array}{l}30 \\
70 \\
60\end{array}$ & $\begin{array}{l}80 \\
60 \\
60\end{array}$ & $\begin{array}{r}-- \\
330 \\
310\end{array}$ & $\begin{array}{l}30 \\
20 \\
20\end{array}$ & $\begin{array}{l}140 \\
160 \\
160\end{array}$ & $\begin{array}{l}3 \\
-- \\
--\end{array}$ & $\begin{array}{l}1,700 \\
1,500 \\
1,500\end{array}$ & $\begin{array}{r}84 \\
<20 \\
<20\end{array}$ \\
\hline 10 & $\begin{array}{l}3 \\
6 \\
9\end{array}$ & $\begin{array}{l}8-13-86 \\
2-26-86 \\
2-25-86 \\
2-26-86\end{array}$ & $\begin{array}{r}30 \\
<10 \\
10 \\
10\end{array}$ & $\begin{array}{l}2 \\
4 \\
2 \\
2\end{array}$ & $\begin{array}{l}20,000 \\
24,000 \\
25,000 \\
25,000\end{array}$ & $\begin{array}{l}20 \\
20 \\
40 \\
30\end{array}$ & $\begin{array}{r}90 \\
70 \\
110 \\
90\end{array}$ & $\begin{array}{r}360 \\
-- \\
-- \\
--\end{array}$ & $\begin{array}{l}20 \\
20 \\
40 \\
30\end{array}$ & $\begin{array}{r}26 \\
64 \\
150 \\
140\end{array}$ & $\begin{array}{l}-- \\
<1 \\
<1 \\
<1\end{array}$ & $\begin{array}{l}1,200 \\
2,600 \\
4,900 \\
5,200\end{array}$ & $\begin{array}{r}<20 \\
20 \\
41 \\
35\end{array}$ \\
\hline 11 & $\begin{array}{r}3 \\
6 \\
12\end{array}$ & $\begin{array}{l}8-13-86 \\
2-26-86 \\
2-26-86\end{array}$ & $\begin{array}{l}20 \\
10 \\
20\end{array}$ & $\begin{array}{l}3 \\
4 \\
3\end{array}$ & $\begin{array}{l}28,000 \\
27,000 \\
21,000\end{array}$ & $\begin{array}{l}20 \\
20 \\
20\end{array}$ & $\begin{array}{l}90 \\
90 \\
90\end{array}$ & $\begin{array}{r}470 \\
-- \\
--\end{array}$ & $\begin{array}{l}20 \\
20 \\
80\end{array}$ & $\begin{array}{r}17 \\
90 \\
120\end{array}$ & $\begin{array}{l}-- \\
<1 \\
<1\end{array}$ & $\begin{array}{l}1,000 \\
4,600 \\
2,600\end{array}$ & $\begin{array}{r}<40 \\
27 \\
65\end{array}$ \\
\hline 12 & 3 & $\begin{array}{l}7-16-86 \\
7-29-86 \\
8-13-86 \\
7-17-86 \\
7-31-86\end{array}$ & $\begin{array}{l}40 \\
30 \\
20 \\
10 \\
10\end{array}$ & $\begin{array}{r}3 \\
3 \\
3 \\
15 \\
13\end{array}$ & $\begin{array}{l}40,000 \\
39,000 \\
40,000 \\
20,000 \\
25,000\end{array}$ & $\begin{array}{r}20 \\
20 \\
20 \\
110 \\
60\end{array}$ & $\begin{array}{r}140 \\
100 \\
80 \\
150 \\
60\end{array}$ & $\begin{array}{l}480 \\
450 \\
500 \\
250 \\
270\end{array}$ & $\begin{array}{l}30 \\
20 \\
20 \\
60 \\
60\end{array}$ & $\begin{array}{r}25 \\
19 \\
26 \\
440 \\
74\end{array}$ & $\begin{array}{l}-- \\
-- \\
-- \\
-- \\
--\end{array}$ & $\begin{array}{r}980 \\
900 \\
1,000 \\
2,100 \\
2,400\end{array}$ & $\begin{array}{r}<40 \\
<40 \\
40 \\
25 \\
<30\end{array}$ \\
\hline 13 & $\begin{array}{r}3 \\
6 \\
12\end{array}$ & $\begin{array}{l}8-14-86 \\
3-06-86 \\
4-02-87 \\
2-27-86 \\
4-02-87\end{array}$ & $\begin{array}{r}20 \\
10 \\
<10 \\
-- \\
30\end{array}$ & $\begin{array}{c}3 \\
5 \\
-- \\
1 \\
--\end{array}$ & $\begin{array}{l}55,000 \\
28,000 \\
17,000 \\
11,000 \\
11,000\end{array}$ & $\begin{array}{l}40 \\
20 \\
30 \\
40 \\
40\end{array}$ & $\begin{array}{r}100 \\
90 \\
40 \\
-- \\
40\end{array}$ & $\begin{array}{r}450 \\
-- \\
240 \\
-- \\
240\end{array}$ & $\begin{array}{c}20 \\
20 \\
20 \\
-- \\
20\end{array}$ & $\begin{array}{r}33 \\
80 \\
110 \\
100 \\
160\end{array}$ & $\begin{array}{r}-- \\
<1 \\
1 \\
1 \\
<1\end{array}$ & $\begin{array}{r}2,700 \\
2,400 \\
1,100 \\
790 \\
870\end{array}$ & $\begin{array}{r}<50 \\
80 \\
<60 \\
42 \\
<60\end{array}$ \\
\hline 14 & $\begin{array}{l}3 \\
6 \\
8\end{array}$ & $\begin{array}{l}7-30-86 \\
8-14-86 \\
3-06-86 \\
4-02-87 \\
2-27-86 \\
4-02-87\end{array}$ & $\begin{array}{r}10 \\
20 \\
20 \\
10 \\
<10 \\
<10\end{array}$ & $\begin{array}{c}2 \\
3 \\
3 \\
-- \\
2 \\
--\end{array}$ & $\begin{array}{l}47,000 \\
48,000 \\
42,000 \\
48,000 \\
47,000 \\
45,000\end{array}$ & $\begin{array}{r}20 \\
40 \\
8 \\
<1 \\
4 \\
7\end{array}$ & $\begin{array}{r}60 \\
110 \\
100 \\
100 \\
130 \\
100\end{array}$ & $\begin{array}{r}520 \\
510 \\
-- \\
350 \\
-- \\
300\end{array}$ & $\begin{array}{l}20 \\
20 \\
30 \\
40 \\
70 \\
60\end{array}$ & $\begin{array}{r}25 \\
31 \\
80 \\
78 \\
85 \\
100\end{array}$ & $\begin{array}{r}-- \\
-- \\
4 \\
7 \\
14 \\
12\end{array}$ & $\begin{array}{l}2,700 \\
2,900 \\
8,200 \\
6,000 \\
9,500 \\
7,300\end{array}$ & $\begin{array}{l}<50 \\
<50 \\
100 \\
<60 \\
130 \\
<60\end{array}$ \\
\hline 15 & $\begin{array}{l}3 \\
6\end{array}$ & $\begin{array}{l}8-14-86 \\
3-06-86 \\
8-31-88 \\
2-27-86 \\
8-31-88\end{array}$ & $\begin{array}{r}<10 \\
10 \\
10 \\
10 \\
<10\end{array}$ & $\begin{array}{c}2 \\
2 \\
-- \\
2 \\
--\end{array}$ & $\begin{array}{r}21,000 \\
28,000 \\
27,000 \\
9,700 \\
9,700\end{array}$ & $\begin{array}{l}20 \\
30 \\
40 \\
40 \\
60\end{array}$ & $\begin{array}{l}60 \\
80 \\
70 \\
70 \\
40\end{array}$ & $\begin{array}{r}400 \\
-- \\
320 \\
-- \\
290\end{array}$ & $\begin{array}{r}20 \\
20 \\
20 \\
30 \\
<10\end{array}$ & $\begin{array}{r}16 \\
140 \\
82 \\
68 \\
60\end{array}$ & $\begin{array}{r}-- \\
1 \\
5 \\
<1 \\
1\end{array}$ & $\begin{array}{r}440 \\
4,200 \\
3,300 \\
990 \\
960\end{array}$ & $\begin{array}{r}<10 \\
35 \\
74 \\
26 \\
33\end{array}$ \\
\hline
\end{tabular}


Table 5. Chemical analysis of drilling-core samples

[Cluster site: Site at which one to five observation wells were installed at different depths. $\mathrm{m}$, meter; $\mu \mathrm{g} / \mathrm{g}$, microgram per gram; --, no data]

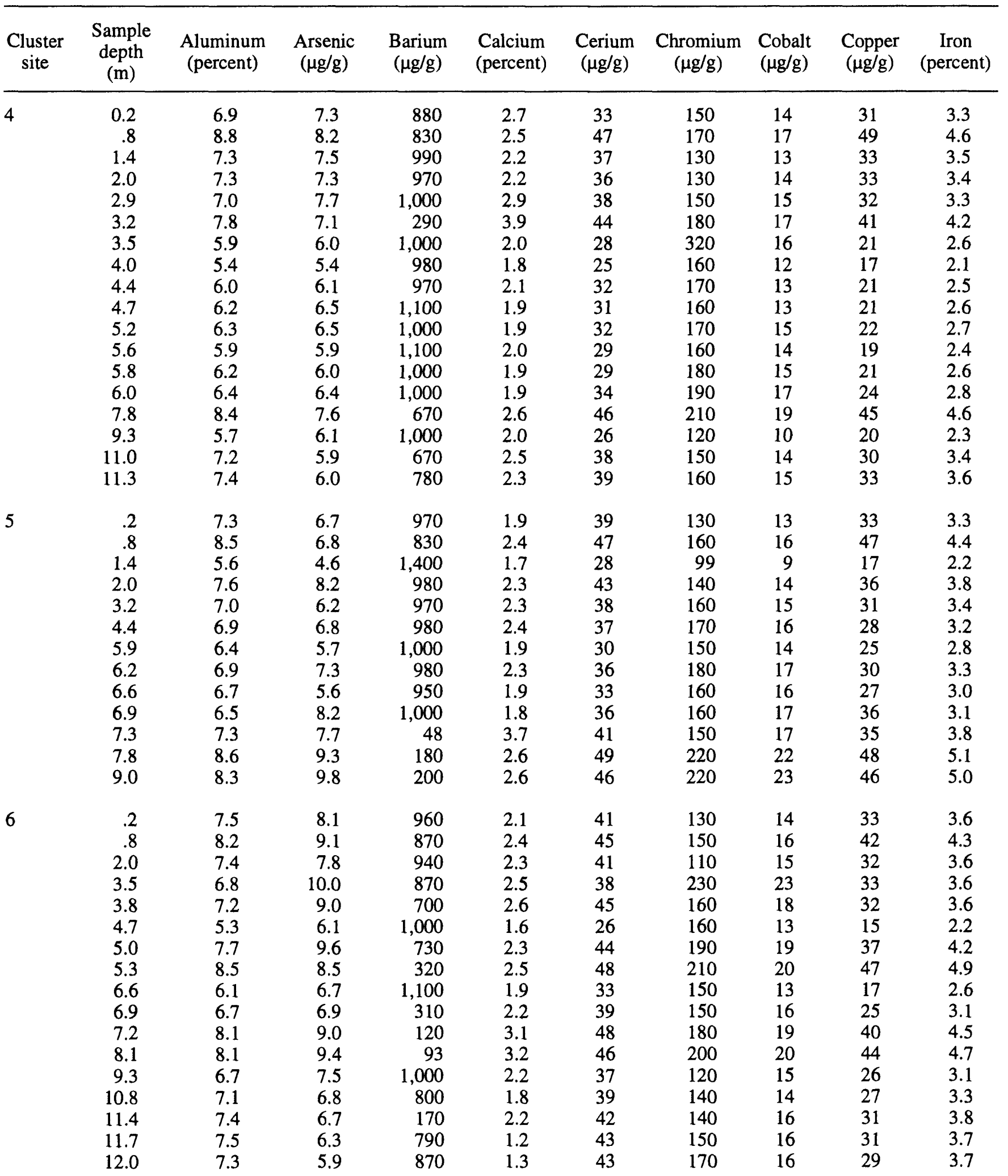


Table 5. Chemical analysis of drilling-core samples--Continued

\begin{tabular}{|c|c|c|c|c|c|c|c|c|c|c|}
\hline $\begin{array}{l}\text { Cluster } \\
\text { site }\end{array}$ & $\begin{array}{l}\text { Sample } \\
\text { depth } \\
\text { (m) }\end{array}$ & $\begin{array}{l}\text { Lanthanum } \\
\qquad(\mu \mathrm{g} / \mathrm{g})\end{array}$ & $\begin{array}{l}\text { Lead } \\
(\mu \mathrm{g} / \mathrm{g})\end{array}$ & $\begin{array}{c}\text { Lithium } \\
(\mu \mathrm{g} / \mathrm{g})\end{array}$ & $\begin{array}{c}\text { Magnesium } \\
\text { (percent) }\end{array}$ & $\begin{array}{c}\text { Manganese } \\
(\mu \mathrm{g} / \mathrm{g})\end{array}$ & $\begin{array}{l}\text { Molybdenum } \\
(\mu \mathrm{g} / \mathrm{g})\end{array}$ & $\begin{array}{l}\text { Neodymium } \\
(\mu \mathrm{g} / \mathrm{g})\end{array}$ & $\begin{array}{l}\text { Nickel } \\
(\mu \mathrm{g} / \mathrm{g})\end{array}$ & $\begin{array}{l}\text { Phos- } \\
\text { phorus } \\
(\mu \mathrm{g} / \mathrm{g})\end{array}$ \\
\hline \multirow[t]{18}{*}{4} & 0.2 & 20 & 12 & 49 & 1.7 & 530 & $<2$ & 17 & 110 & 0.06 \\
\hline & .8 & 27 & 17 & 80 & 1.7 & 590 & 3 & 22 & 91 & .07 \\
\hline & 1.4 & 21 & 14 & 55 & 1.4 & 530 & $<2$ & 18 & 78 & .06 \\
\hline & 2.0 & 21 & 14 & 53 & 1.4 & 560 & $<2$ & 15 & 81 & .06 \\
\hline & 2.9 & 21 & 14 & 50 & 1.8 & 590 & $<2$ & 17 & 120 & .06 \\
\hline & 3.2 & 23 & 10 & 69 & 2.1 & 590 & $<2$ & 20 & 120 & .07 \\
\hline & 3.5 & 16 & 12 & 31 & 2.2 & 480 & $<2$ & 13 & 190 & .05 \\
\hline & 4.0 & 14 & 12 & 25 & 1.8 & 420 & $<2$ & 10 & 140 & .05 \\
\hline & 4.4 & 17 & 12 & 32 & 1.7 & 500 & $<2$ & 14 & 130 & .05 \\
\hline & 4.7 & 17 & 12 & 32 & 1.7 & 490 & $<2$ & 14 & 120 & .05 \\
\hline & 5.2 & 17 & 11 & 34 & 2.1 & 510 & $<2$ & 14 & 150 & .05 \\
\hline & 5.6 & 16 & 12 & 30 & 1.8 & 480 & $<2$ & 14 & 130 & .05 \\
\hline & 5.8 & 17 & 12 & 32 & 2.1 & 510 & $<2$ & 13 & 160 & .05 \\
\hline & 6.0 & 18 & 11 & 35 & 2.3 & 570 & $<2$ & 15 & 180 & .06 \\
\hline & 7.8 & 25 & 15 & 73 & 2.5 & 660 & $<2$ & 21 & 150 & .08 \\
\hline & 9.3 & 14 & 11 & 30 & 1.3 & 440 & $<2$ & 13 & 84 & .05 \\
\hline & 11.0 & 21 & 12 & 51 & 1.7 & 520 & $<2$ & 18 & 99 & .06 \\
\hline & 11.3 & 21 & 14 & 54 & 1.8 & 570 & $<2$ & 18 & 110 & .06 \\
\hline \multirow[t]{13}{*}{5} & .2 & 22 & 15 & 54 & 1.3 & 480 & $<2$ & 18 & 75 & .06 \\
\hline & .8 & 26 & 14 & 76 & 1.7 & 600 & $<2$ & 20 & 93 & .06 \\
\hline & 1.4 & 16 & 10 & 27 & 0.8 & 430 & $<2$ & 13 & 55 & .04 \\
\hline & 2.0 & 24 & 14 & 60 & 1.5 & 540 & $<2$ & 21 & 85 & .06 \\
\hline & 3.2 & 21 & 13 & 51 & 1.8 & 570 & $<2$ & 17 & 120 & .07 \\
\hline & 4.4 & 20 & 12 & 43 & 1.9 & 610 & $<2$ & 17 & 140 & .06 \\
\hline & 5.9 & 17 & 10 & 38 & 1.8 & 520 & $<2$ & 14 & 130 & .06 \\
\hline & 6.2 & 20 & 12 & 44 & 2.1 & 570 & $<2$ & 17 & 150 & .06 \\
\hline & 6.6 & 18 & 13 & 40 & 1.9 & 560 & $<2$ & 15 & 140 & .05 \\
\hline & 6.9 & 19 & 15 & 38 & 2.0 & 570 & $<2$ & 15 & 180 & .05 \\
\hline & 7.3 & 21 & 9 & 56 & 2.1 & 610 & $<2$ & 19 & 120 & .06 \\
\hline & 7.8 & 26 & 13 & 76 & 2.7 & 750 & 2 & 22 & 170 & .08 \\
\hline & 9.0 & 25 & 12 & 72 & 2.8 & 700 & $<2$ & 22 & 190 & .07 \\
\hline \multirow[t]{17}{*}{6} & .2 & 22 & 19 & 55 & 1.3 & 530 & $<2$ & 18 & 77 & .07 \\
\hline & .8 & 25 & 16 & 69 & 1.6 & 580 & $<2$ & 21 & 90 & .06 \\
\hline & 2.0 & 22 & 15 & 52 & 1.4 & 560 & $<2$ & 18 & 80 & .06 \\
\hline & 3.5 & 20 & 14 & 46 & 3.0 & 650 & $<2$ & 17 & 260 & .07 \\
\hline & 3.8 & 25 & 13 & 50 & 2.0 & 630 & $<2$ & 19 & 140 & .07 \\
\hline & 4.7 & 15 & 12 & 22 & 2.1 & 420 & $<2$ & 11 & 160 & .05 \\
\hline & 5.0 & 24 & 14 & 58 & 2.3 & 660 & $<2$ & 21 & 150 & .07 \\
\hline & 5.3 & 27 & 12 & 72 & 2.5 & 630 & $<2$ & 22 & 160 & .08 \\
\hline & 6.6 & 18 & 14 & 29 & 1.6 & 520 & $<2$ & 15 & 130 & .05 \\
\hline & 6.9 & 20 & 11 & 40 & 2.0 & 610 & $<2$ & 16 & 140 & .06 \\
\hline & 7.2 & 25 & 11 & 67 & 2.4 & 690 & $<2$ & 21 & 140 & .08 \\
\hline & 8.1 & 24 & 11 & 70 & 2.6 & 680 & $<2$ & 22 & 160 & .07 \\
\hline & 9.3 & 20 & 14 & 40 & 1.5 & 580 & $<2$ & 17 & 95 & .06 \\
\hline & 10.8 & 20 & 16 & 47 & 1.6 & 570 & $<2$ & 17 & 100 & .06 \\
\hline & 11.4 & 22 & 12 & 53 & 1.7 & 680 & $<2$ & 18 & 110 & .06 \\
\hline & 11.7 & 23 & 15 & 50 & 1.7 & 600 & $<2$ & 19 & 110 & .06 \\
\hline & 12.0 & 24 & 14 & 46 & 1.7 & 640 & $<2$ & 20 & 120 & .08 \\
\hline
\end{tabular}


Table 5. Chemical analysis of drilling-core samples--Continued

\begin{tabular}{|c|c|c|c|c|c|c|c|c|c|}
\hline $\begin{array}{l}\text { Cluster } \\
\text { site }\end{array}$ & $\begin{array}{c}\text { Sample } \\
\text { depth } \\
\text { (m) }\end{array}$ & $\begin{array}{c}\text { Potassium } \\
\text { (percent) }\end{array}$ & $\begin{array}{l}\text { Scandium } \\
(\mu \mathrm{g} / \mathrm{g})\end{array}$ & $\begin{array}{c}\text { Total } \\
\text { selenium } \\
(\mu \mathrm{g} / \mathrm{g})\end{array}$ & $\begin{array}{c}\text { Soluble } \\
\text { selenium } \\
(\mu \mathrm{g} / \mathrm{g})\end{array}$ & $\begin{array}{c}\text { Residual } \\
\text { selenium } \\
(\mu \mathrm{g} / \mathrm{g})\end{array}$ & $\begin{array}{l}\text { Silver } \\
(\mu \mathrm{g} / \mathrm{g})\end{array}$ & $\begin{array}{l}\text { Sodium } \\
\text { (percent) }\end{array}$ & $\begin{array}{l}\text { Strontium } \\
(\mu \mathrm{g} / \mathrm{g})\end{array}$ \\
\hline \multirow[t]{18}{*}{4} & 0.2 & 1.9 & 10 & 1.7 & 1.49 & 0.21 & $<2$ & 1.5 & 280 \\
\hline & .8 & 1.7 & 16 & 1.4 & .59 & .81 & $<2$ & 1.2 & 240 \\
\hline & 1.4 & 2.0 & 11 & 1.1 & .49 & .61 & $<2$ & 1.4 & 260 \\
\hline & 2.0 & 2.0 & 11 & 1.0 & .39 & .61 & $<2$ & 1.5 & 270 \\
\hline & 2.9 & 1.9 & 10 & .6 & .12 & .48 & $<2$ & 1.6 & 290 \\
\hline & 3.2 & 1.7 & 14 & .7 & .23 & .47 & $<2$ & 1.1 & 330 \\
\hline & 3.5 & 2.0 & 7 & .6 & .23 & .37 & $<2$ & 1.6 & 270 \\
\hline & 4.0 & 2.2 & 6 & .6 & .29 & .31 & $<2$ & 1.5 & 250 \\
\hline & 4.4 & 2.1 & 8 & .6 & .29 & .31 & $<2$ & 1.5 & 260 \\
\hline & 4.7 & 2.1 & 8 & .6 & .39 & .21 & $<2$ & 1.7 & 270 \\
\hline & 5.2 & 1.9 & 8 & .7 & .47 & .23 & $<2$ & 1.7 & 280 \\
\hline & 5.6 & 2.1 & 7 & .6 & .42 & .18 & $<2$ & 1.6 & 260 \\
\hline & 5.8 & 2.0 & 8 & .8 & .46 & .34 & $<2$ & 1.8 & 270 \\
\hline & 6.0 & 1.9 & 8 & 1.1 & .91 & .19 & $<2$ & 1.8 & 260 \\
\hline & 7.8 & 1.7 & 16 & 1.1 & .85 & .25 & $<2$ & 1.3 & 280 \\
\hline & 9.3 & 2.1 & 7 & 1.5 & 1.60 & .00 & $<2$ & 1.6 & 270 \\
\hline & 11.0 & 2.0 & 11 & .8 & .42 & .38 & $<2$ & 1.3 & 270 \\
\hline & 11.3 & 2.0 & 12 & .6 & .24 & .36 & $<2$ & 1.4 & 250 \\
\hline \multirow[t]{13}{*}{5} & .2 & 2.1 & 11 & .8 & .01 & .79 & $<2$ & 1.1 & 230 \\
\hline & .8 & 1.6 & 16 & .7 & .34 & .36 & $<2$ & 1.2 & 240 \\
\hline & 1.4 & 2.1 & 6 & .6 & .32 & .28 & $<2$ & 1.5 & 240 \\
\hline & 2.0 & 1.9 & 13 & 1.1 & .48 & .62 & $<2$ & 1.4 & 260 \\
\hline & 3.2 & 2.0 & 11 & .6 & .12 & .48 & $<2$ & 1.4 & 260 \\
\hline & 4.4 & 1.8 & 10 & .8 & .42 & .38 & $<2$ & 1.7 & 280 \\
\hline & 5.9 & 2.0 & 9 & .8 & .51 & .29 & $<2$ & 1.6 & 270 \\
\hline & 6.2 & 1.9 & 10 & .9 & .56 & .34 & $<2$ & 1.7 & 280 \\
\hline & 6.6 & 2.0 & 9 & .7 & .78 & .00 & $<2$ & 1.8 & 270 \\
\hline & 6.9 & 1.9 & 9 & 1.1 & .89 & .21 & $<2$ & 1.7 & 270 \\
\hline & 7.3 & 1.7 & 12 & 1.1 & .76 & .32 & $<2$ & 1.4 & 570 \\
\hline & 7.8 & 1.7 & 18 & 1.1 & .80 & .30 & $<2$ & 1.2 & 250 \\
\hline & 9.0 & 1.7 & 17 & 1.5 & 1.22 & .28 & $<2$ & 1.1 & 240 \\
\hline \multirow[t]{17}{*}{6} & .2 & 1.9 & 11 & .9 & .01 & .89 & $<2$ & 1.2 & 240 \\
\hline & .8 & 1.7 & 15 & 1.0 & .19 & .81 & $<2$ & 1.3 & 240 \\
\hline & 2.0 & 1.9 & 11 & 1.2 & .40 & .80 & $<2$ & 1.7 & 270 \\
\hline & 3.5 & 1.7 & 11 & .7 & .35 & .35 & $<2$ & 1.5 & 260 \\
\hline & 3.8 & 1.6 & 11 & .7 & .34 & .36 & $<2$ & 1.5 & 280 \\
\hline & 4.7 & 2.0 & 6 & .5 & .27 & .23 & $<2$ & 1.5 & 240 \\
\hline & 5.0 & 1.7 & 14 & .8 & .42 & .38 & $<2$ & 1.4 & 240 \\
\hline & 5.3 & 1.7 & 17 & .8 & .47 & .33 & 5 & 1.1 & 230 \\
\hline & 6.6 & 2.1 & 7 & 1.1 & .88 & .22 & $<2$ & 1.8 & 280 \\
\hline & 6.9 & 1.8 & 9 & 1.1 & .95 & .15 & $<2$ & 1.8 & 340 \\
\hline & 7.2 & 1.8 & 15 & 1.2 & 1.00 & .20 & $<2$ & 1.4 & 320 \\
\hline & 8.1 & 1.6 & 16 & 1.4 & 1.09 & .31 & $<2$ & 1.2 & 260 \\
\hline & 9.3 & 1.9 & 9 & 1.2 & 1.16 & .04 & $<2$ & 1.8 & 280 \\
\hline & 10.8 & 2.0 & 11 & .6 & .31 & .29 & $<2$ & 1.4 & 270 \\
\hline & 11.4 & 1.9 & 12 & .6 & .23 & .37 & $<2$ & 1.3 & 240 \\
\hline & 11.7 & 1.8 & 12 & .5 & .16 & .34 & $<2$ & 1.4 & 240 \\
\hline & 12.0 & 2.0 & 12 & .5 & .19 & .31 & $<2$ & 1.5 & 250 \\
\hline
\end{tabular}


Table 5. Chemical analysis of drilling-core samples--Continued

\begin{tabular}{|c|c|c|c|c|c|c|c|c|c|c|}
\hline $\begin{array}{l}\text { Cluster } \\
\text { site }\end{array}$ & $\begin{array}{l}\text { Sample } \\
\text { depth } \\
\text { (m) }\end{array}$ & $\begin{array}{c}\text { Thorium } \\
(\mu \mathrm{g} / \mathrm{g})\end{array}$ & $\begin{array}{c}\text { Titanium } \\
(\mu \mathrm{g} / \mathrm{g})\end{array}$ & $\begin{array}{c}\text { Tin } \\
\text { (percent) }\end{array}$ & $\begin{array}{l}\text { Vanadium } \\
(\mu \mathrm{g} / \mathrm{g})\end{array}$ & $\begin{array}{c}\text { Yttrium } \\
(\mu \mathrm{g} / \mathrm{g})\end{array}$ & $\begin{array}{l}\text { Zinc } \\
(\mu \mathrm{g} / \mathrm{g})\end{array}$ & $\begin{array}{c}\text { Total } \\
\text { carbon } \\
\text { (percent) }\end{array}$ & $\begin{array}{l}\text { Organic } \\
\text { carbon } \\
\text { (percent) }\end{array}$ & $\begin{array}{c}\text { Carbonate } \\
\text { (percent) }\end{array}$ \\
\hline \multirow[t]{18}{*}{4} & 0.2 & 8 & 0.29 & $<20$ & 98 & 14 & 80 & 0.41 & 0.14 & 0.27 \\
\hline & .8 & 13 & .39 & $<20$ & 150 & 17 & 130 & .82 & .43 & .39 \\
\hline & 1.4 & 10 & .31 & $<20$ & 110 & 14 & 95 & .54 & .26 & .28 \\
\hline & 2.0 & 10 & .31 & $<20$ & 100 & 15 & 91 & .53 & .26 & .27 \\
\hline & 2.9 & 8 & .31 & $<20$ & 95 & 15 & 80 & .57 & .14 & .43 \\
\hline & 3.2 & 10 & .37 & $<20$ & 130 & 17 & 100 & .50 & .19 & .31 \\
\hline & 3.5 & 6 & .22 & $<20$ & 66 & 12 & 53 & .31 & .06 & .25 \\
\hline & 4.0 & 4 & .17 & $<20$ & 51 & 10 & 43 & .26 & .05 & .21 \\
\hline & 4.4 & 5 & .24 & $<20$ & 68 & 13 & 57 & .26 & .06 & .20 \\
\hline & 4.7 & 6 & .24 & $<20$ & 69 & 13 & 56 & .30 & .07 & .23 \\
\hline & 5.2 & 5 & .25 & $<20$ & 72 & 12 & 58 & .27 & .07 & .20 \\
\hline & 5.6 & 6 & .23 & $<20$ & 65 & 11 & 57 & .27 & .06 & .21 \\
\hline & 5.8 & 6 & .24 & $<20$ & 69 & 12 & 55 & .28 & .08 & .20 \\
\hline & 6.0 & 9 & .26 & $<20$ & 75 & 13 & 59 & .31 & .09 & .22 \\
\hline & 7.8 & 11 & .38 & $<20$ & 140 & 17 & 120 & .40 & .14 & .26 \\
\hline & 9.3 & 4 & .22 & $<20$ & 63 & 11 & 52 & .34 & .07 & .27 \\
\hline & 11.0 & 9 & .30 & $<20$ & 100 & 15 & 85 & .30 & .08 & .22 \\
\hline & 11.3 & 9 & .31 & $<20$ & 110 & 15 & 90 & .32 & .15 & .17 \\
\hline \multirow[t]{13}{*}{5} & .2 & 10 & .29 & $<20$ & 100 & 15 & 92 & .92 & .68 & .24 \\
\hline & .8 & 12 & .38 & $<20$ & 150 & 17 & 120 & .76 & .37 & .39 \\
\hline & 1.4 & 5 & .22 & $<20$ & 56 & 10 & 49 & .34 & .12 & .22 \\
\hline & 2.0 & 11 & .33 & $<20$ & 120 & 17 & 98 & .50 & .20 & .30 \\
\hline & 3.2 & 8 & .31 & $<20$ & 97 & 15 & 81 & .52 & .20 & .32 \\
\hline & 4.4 & 7 & .30 & $<20$ & 88 & 15 & 72 & .46 & .11 & .35 \\
\hline & 5.9 & 6 & .25 & $<20$ & 80 & 13 & 65 & .26 & .09 & .17 \\
\hline & 6.2 & 8 & .31 & $<20$ & 91 & 14 & 75 & .38 & .12 & .26 \\
\hline & 6.6 & 7 & .27 & $<20$ & 81 & 13 & 69 & .34 & .13 & .21 \\
\hline & 6.9 & 7 & .28 & $<20$ & 80 & 13 & 110 & .30 & .10 & .20 \\
\hline & 7.3 & 8 & .34 & $<20$ & 110 & 15 & 93 & .31 & .10 & .21 \\
\hline & 7.8 & 11 & .41 & $<20$ & 160 & 17 & 120 & .45 & .15 & .30 \\
\hline & 9.0 & 11 & .39 & $<20$ & 150 & 17 & 120 & .44 & .15 & .29 \\
\hline \multirow[t]{17}{*}{6} & .2 & 10 & .31 & $<20$ & 110 & 14 & 100 & 1.01 & .76 & .25 \\
\hline & .8 & 12 & .36 & $<20$ & 140 & 15 & 120 & .69 & .31 & .38 \\
\hline & 2.0 & 9 & .33 & $<20$ & 100 & 14 & 92 & .47 & .20 & .27 \\
\hline & 3.5 & 8 & .30 & $<20$ & 96 & 14 & 77 & .49 & .15 & .34 \\
\hline & 3.8 & 11 & .34 & $<20$ & 100 & 15 & 85 & .42 & .12 & .30 \\
\hline & 4.7 & 5 & .18 & $<20$ & 52 & 9 & 44 & .26 & .06 & .20 \\
\hline & 5.0 & 10 & .37 & $<20$ & 120 & 16 & 99 & .41 & .15 & .26 \\
\hline & 5.3 & 12 & .40 & $<20$ & 160 & 17 & 120 & .43 & .17 & .26 \\
\hline & 6.6 & 6 & .27 & $<20$ & 65 & 11 & 53 & .22 & .05 & .17 \\
\hline & 6.9 & 7 & .29 & $<20$ & 85 & 14 & 71 & .28 & .07 & .21 \\
\hline & 7.2 & 12 & .39 & $<20$ & 130 & 17 & 110 & .43 & .12 & .31 \\
\hline & 8.1 & 11 & .38 & $<20$ & 140 & 16 & 110 & .47 & .13 & .34 \\
\hline & 9.3 & 9 & .28 & $<20$ & 82 & 13 & 72 & .36 & .08 & .28 \\
\hline & 10.8 & 9 & .29 & $<20$ & 97 & 13 & 81 & .22 & .03 & .19 \\
\hline & 11.4 & 8 & .32 & $<20$ & 110 & 14 & 93 & .18 & .05 & .13 \\
\hline & 11.7 & 10 & .33 & $<20$ & 110 & 14 & 92 & .10 & .03 & .07 \\
\hline & 12.0 & 9 & .34 & $<20$ & 100 & 15 & 88 & .08 & .03 & .05 \\
\hline
\end{tabular}


Table 5. Chemical analysis of drilling-core samples--Continued

\begin{tabular}{|c|c|c|c|c|c|c|c|c|c|c|}
\hline $\begin{array}{l}\text { Cluster } \\
\text { site }\end{array}$ & $\begin{array}{c}\text { Sample } \\
\text { depth } \\
\text { (m) }\end{array}$ & $\begin{array}{c}\text { Aluminum } \\
\text { (percent) }\end{array}$ & $\begin{array}{c}\text { Arsenic } \\
(\mu \mathrm{g} / \mathrm{g})\end{array}$ & $\begin{array}{c}\text { Barium } \\
(\mu \mathrm{g} / \mathrm{g})\end{array}$ & $\begin{array}{l}\text { Calcium } \\
\text { (percent) }\end{array}$ & $\begin{array}{c}\text { Cerium } \\
(\mu \mathrm{g} / \mathrm{g})\end{array}$ & $\begin{array}{l}\text { Chromium } \\
(\mu \mathrm{g} / \mathrm{g})\end{array}$ & $\begin{array}{l}\text { Cobalt } \\
(\mu \mathrm{g} / \mathrm{g})\end{array}$ & $\begin{array}{c}\text { Copper } \\
(\mu \mathrm{g} / \mathrm{g})\end{array}$ & $\begin{array}{c}\text { Iron } \\
\text { (percent) }\end{array}$ \\
\hline 7 & $\begin{array}{r}0.2 \\
.8 \\
2.0 \\
3.2 \\
3.8 \\
4.7 \\
5.2 \\
5.6 \\
5.9 \\
6.9 \\
7.2 \\
8.4 \\
10.5 \\
11.4 \\
12.1\end{array}$ & $\begin{array}{l}7.4 \\
8.8 \\
7.4 \\
8.4 \\
7.3 \\
5.6 \\
8.5 \\
7.3 \\
5.6 \\
6.6 \\
8.2 \\
8.5 \\
7.1 \\
7.7 \\
7.1\end{array}$ & $\begin{array}{l}7.7 \\
8.5 \\
8.3 \\
9.1 \\
9.1 \\
6.3 \\
8.0 \\
5.5 \\
5.3 \\
7.2 \\
9.3 \\
7.4 \\
5.9 \\
6.0 \\
5.6\end{array}$ & $\begin{array}{r}930 \\
900 \\
950 \\
140 \\
760 \\
1,300 \\
770 \\
860 \\
1,100 \\
1,000 \\
530 \\
730 \\
880 \\
860 \\
880\end{array}$ & $\begin{array}{l}2.0 \\
2.6 \\
2.2 \\
3.2 \\
2.7 \\
1.8 \\
2.1 \\
2.2 \\
1.9 \\
2.0 \\
3.0 \\
2.2 \\
2.6 \\
1.5 \\
1.9\end{array}$ & $\begin{array}{l}45 \\
52 \\
42 \\
49 \\
44 \\
32 \\
43 \\
37 \\
27 \\
32 \\
45 \\
45 \\
36 \\
40 \\
38\end{array}$ & $\begin{array}{l}110 \\
150 \\
120 \\
190 \\
170 \\
150 \\
200 \\
180 \\
170 \\
150 \\
160 \\
190 \\
130 \\
150 \\
170\end{array}$ & $\begin{array}{l}14 \\
18 \\
15 \\
19 \\
19 \\
12 \\
19 \\
19 \\
13 \\
16 \\
17 \\
20 \\
13 \\
16 \\
16\end{array}$ & $\begin{array}{l}32 \\
46 \\
34 \\
41 \\
35 \\
15 \\
48 \\
36 \\
18 \\
25 \\
44 \\
45 \\
31 \\
32 \\
29\end{array}$ & $\begin{array}{l}3.6 \\
4.7 \\
3.7 \\
4.7 \\
3.9 \\
2.2 \\
4.8 \\
3.8 \\
2.2 \\
2.8 \\
4.4 \\
4.7 \\
3.2 \\
3.7 \\
3.5\end{array}$ \\
\hline 11 & $\begin{array}{r}.2 \\
.8 \\
2.0 \\
3.2 \\
4.3 \\
5.3 \\
5.6 \\
5.9 \\
6.2 \\
6.6 \\
6.9 \\
7.8 \\
8.7 \\
9.6 \\
10.5 \\
11.4 \\
11.7\end{array}$ & $\begin{array}{l}7.6 \\
8.7 \\
7.6 \\
6.9 \\
7.4 \\
8.5 \\
7.7 \\
7.2 \\
6.9 \\
6.6 \\
6.9 \\
7.9 \\
8.6 \\
7.4 \\
7.5 \\
7.7 \\
7.4\end{array}$ & $\begin{array}{l}7.6 \\
8.0 \\
8.3 \\
5.5 \\
7.8 \\
5.9 \\
7.9 \\
8.2 \\
7.8 \\
6.8 \\
7.5 \\
8.7 \\
8.2 \\
9.5 \\
6.4 \\
5.1 \\
5.5\end{array}$ & $\begin{array}{r}980 \\
910 \\
990 \\
930 \\
930 \\
740 \\
890 \\
840 \\
990 \\
1,100 \\
98 \\
550 \\
700 \\
180 \\
850 \\
820 \\
860\end{array}$ & $\begin{array}{l}2.0 \\
2.4 \\
2.3 \\
2.4 \\
2.3 \\
2.7 \\
2.7 \\
2.8 \\
2.1 \\
1.9 \\
4.0 \\
3.1 \\
2.4 \\
3.5 \\
2.1 \\
1.8 \\
1.9\end{array}$ & $\begin{array}{l}39 \\
46 \\
41 \\
33 \\
38 \\
43 \\
42 \\
40 \\
36 \\
32 \\
36 \\
43 \\
44 \\
39 \\
37 \\
39 \\
41\end{array}$ & $\begin{array}{l}110 \\
150 \\
120 \\
170 \\
130 \\
200 \\
170 \\
170 \\
160 \\
160 \\
130 \\
180 \\
210 \\
150 \\
140 \\
140 \\
150\end{array}$ & $\begin{array}{l}14 \\
17 \\
15 \\
16 \\
16 \\
21 \\
18 \\
18 \\
16 \\
15 \\
15 \\
19 \\
22 \\
17 \\
14 \\
15 \\
16\end{array}$ & $\begin{array}{l}34 \\
47 \\
36 \\
28 \\
31 \\
49 \\
38 \\
37 \\
30 \\
25 \\
31 \\
44 \\
47 \\
38 \\
30 \\
31 \\
32\end{array}$ & $\begin{array}{l}3.5 \\
4.5 \\
3.7 \\
3.3 \\
3.3 \\
4.9 \\
4.0 \\
3.7 \\
3.2 \\
2.9 \\
3.3 \\
4.3 \\
4.9 \\
3.8 \\
3.5 \\
3.6 \\
3.5\end{array}$ \\
\hline 12 & $\begin{array}{r}.2 \\
.8 \\
1.4 \\
2.0 \\
2.3 \\
3.5 \\
5.3 \\
6.2 \\
7.2 \\
8.2 \\
9.0\end{array}$ & $\begin{array}{l}7.5 \\
7.9 \\
8.0 \\
7.1 \\
7.0 \\
6.6 \\
8.1 \\
7.9 \\
7.4 \\
8.0 \\
6.2\end{array}$ & $\begin{array}{l}8.0 \\
7.6 \\
8.6 \\
6.2 \\
8.1 \\
7.3 \\
8.7 \\
6.2 \\
8.5 \\
8.4 \\
4.7\end{array}$ & $\begin{array}{r}980 \\
850 \\
920 \\
1,000 \\
1,100 \\
890 \\
770 \\
670 \\
660 \\
710 \\
1,100\end{array}$ & $\begin{array}{l}2.0 \\
2.4 \\
2.3 \\
1.9 \\
2.3 \\
2.9 \\
2.6 \\
2.6 \\
2.7 \\
2.5 \\
1.3\end{array}$ & $\begin{array}{l}40 \\
41 \\
41 \\
37 \\
37 \\
34 \\
44 \\
41 \\
39 \\
44 \\
32\end{array}$ & $\begin{array}{l}130 \\
120 \\
130 \\
110 \\
120 \\
210 \\
190 \\
170 \\
160 \\
180 \\
110\end{array}$ & $\begin{array}{l}14 \\
15 \\
15 \\
14 \\
15 \\
22 \\
21 \\
18 \\
18 \\
20 \\
12\end{array}$ & $\begin{array}{l}34 \\
58 \\
40 \\
31 \\
29 \\
31 \\
42 \\
42 \\
37 \\
43 \\
20\end{array}$ & $\begin{array}{l}3.5 \\
3.9 \\
3.9 \\
3.4 \\
3.2 \\
3.3 \\
4.5 \\
4.2 \\
3.8 \\
4.5 \\
2.3\end{array}$ \\
\hline M5 & $\begin{array}{l}.2 \\
.7 \\
1.0 \\
1.5 \\
2.0 \\
2.2\end{array}$ & $\begin{array}{l}6.3 \\
7.7 \\
8.8 \\
8.4 \\
7.7 \\
8.9\end{array}$ & $\begin{array}{l}7.0 \\
8.6 \\
8.8 \\
8.3 \\
8.8 \\
8.6\end{array}$ & $\begin{array}{r}1,100 \\
900 \\
790 \\
770 \\
840 \\
800\end{array}$ & $\begin{array}{l}1.6 \\
2.2 \\
2.4 \\
2.5 \\
1.9 \\
2.6\end{array}$ & $\begin{array}{l}37 \\
42 \\
49 \\
45 \\
42 \\
51\end{array}$ & $\begin{array}{l}100 \\
130 \\
160 \\
150 \\
150 \\
170\end{array}$ & $\begin{array}{l}12 \\
15 \\
17 \\
17 \\
16 \\
20\end{array}$ & $\begin{array}{l}21 \\
37 \\
48 \\
42 \\
38 \\
51\end{array}$ & $\begin{array}{l}2.6 \\
3.7 \\
4.7 \\
4.4 \\
3.9 \\
4.9\end{array}$ \\
\hline
\end{tabular}


Table 5. Chemical analysis of drilling-core samples--Continued

\begin{tabular}{|c|c|c|c|c|c|c|c|c|c|c|}
\hline $\begin{array}{l}\text { Cluster } \\
\text { site }\end{array}$ & $\begin{array}{c}\text { Sample } \\
\text { depth } \\
\text { (m) }\end{array}$ & $\begin{array}{l}\text { Lanthanum } \\
\qquad(\mu \mathrm{g} / \mathrm{g})\end{array}$ & $\begin{array}{l}\text { Lead } \\
(\mu \mathrm{g} / \mathrm{g})\end{array}$ & $\begin{array}{l}\text { Lithium } \\
(\mu \mathrm{g} / \mathrm{g})\end{array}$ & $\begin{array}{c}\text { Magnesium } \\
\text { (percent) }\end{array}$ & $\begin{array}{c}\text { Manganese } \\
(\mu \mathrm{g} / \mathrm{g})\end{array}$ & $\begin{array}{c}\text { Molybdenum } \\
(\mu \mathrm{g} / \mathrm{g})\end{array}$ & $\begin{array}{l}\text { Neodymium } \\
(\mu \mathrm{g} / \mathrm{g})\end{array}$ & $\begin{array}{l}\text { Nickel } \\
(\mu \mathrm{g} / \mathrm{g})\end{array}$ & $\begin{array}{l}\text { Phos- } \\
\text { phorus } \\
(\mu g / g)\end{array}$ \\
\hline 7 & $\begin{array}{r}0.2 \\
.8 \\
2.0 \\
3.2 \\
3.8 \\
4.7 \\
5.2 \\
5.6 \\
5.9 \\
6.9 \\
7.2 \\
8.4 \\
10.5 \\
11.4 \\
12.1\end{array}$ & $\begin{array}{l}25 \\
28 \\
22 \\
26 \\
23 \\
17 \\
26 \\
21 \\
16 \\
18 \\
26 \\
25 \\
21 \\
22 \\
21\end{array}$ & $\begin{array}{l}17 \\
18 \\
17 \\
12 \\
14 \\
12 \\
20 \\
17 \\
17 \\
16 \\
17 \\
18 \\
15 \\
16 \\
16\end{array}$ & $\begin{array}{l}55 \\
75 \\
55 \\
71 \\
54 \\
23 \\
76 \\
57 \\
27 \\
38 \\
76 \\
77 \\
51 \\
57 \\
46\end{array}$ & $\begin{array}{l}1.3 \\
1.7 \\
1.5 \\
2.2 \\
2.2 \\
1.5 \\
2.5 \\
2.1 \\
1.8 \\
1.9 \\
2.3 \\
2.6 \\
1.7 \\
1.8 \\
1.9\end{array}$ & $\begin{array}{l}510 \\
680 \\
580 \\
700 \\
650 \\
480 \\
610 \\
610 \\
430 \\
530 \\
630 \\
660 \\
500 \\
580 \\
600\end{array}$ & $\begin{array}{r}<2 \\
2 \\
<2 \\
2 \\
<2 \\
<2 \\
<2 \\
<2 \\
<2 \\
<2 \\
<2 \\
<2 \\
<2 \\
<2 \\
<2\end{array}$ & $\begin{array}{l}19 \\
23 \\
19 \\
22 \\
19 \\
14 \\
22 \\
19 \\
14 \\
14 \\
23 \\
23 \\
16 \\
19 \\
18\end{array}$ & $\begin{array}{r}74 \\
97 \\
95 \\
130 \\
150 \\
130 \\
150 \\
150 \\
150 \\
140 \\
120 \\
150 \\
97 \\
110 \\
130\end{array}$ & $\begin{array}{r}0.07 \\
.07 \\
.06 \\
.08 \\
.07 \\
.05 \\
.07 \\
.07 \\
.05 \\
.05 \\
.07 \\
.08 \\
.06 \\
.06 \\
.07\end{array}$ \\
\hline 11 & $\begin{array}{r}.2 \\
.8 \\
2.0 \\
3.2 \\
4.3 \\
5.3 \\
5.6 \\
5.9 \\
6.2 \\
6.6 \\
6.9 \\
7.8 \\
8.7 \\
9.6 \\
10.5 \\
11.4 \\
11.7\end{array}$ & $\begin{array}{l}22 \\
26 \\
23 \\
19 \\
22 \\
25 \\
24 \\
21 \\
21 \\
19 \\
20 \\
24 \\
25 \\
22 \\
22 \\
22 \\
23\end{array}$ & $\begin{array}{r}17 \\
21 \\
20 \\
16 \\
19 \\
18 \\
17 \\
18 \\
17 \\
17 \\
9 \\
16 \\
16 \\
12 \\
15 \\
16 \\
17\end{array}$ & $\begin{array}{l}59 \\
79 \\
59 \\
48 \\
51 \\
76 \\
62 \\
55 \\
46 \\
39 \\
51 \\
71 \\
79 \\
63 \\
56 \\
56 \\
50\end{array}$ & $\begin{array}{l}1.3 \\
1.7 \\
1.4 \\
2.1 \\
1.7 \\
2.5 \\
2.2 \\
2.3 \\
2.0 \\
2.0 \\
1.9 \\
2.4 \\
2.6 \\
2.0 \\
1.7 \\
1.7 \\
1.8\end{array}$ & $\begin{array}{l}520 \\
600 \\
590 \\
560 \\
580 \\
660 \\
620 \\
610 \\
550 \\
500 \\
560 \\
630 \\
710 \\
580 \\
510 \\
550 \\
580\end{array}$ & $\begin{array}{l}<2 \\
<2 \\
<2 \\
<2 \\
<2 \\
<2 \\
<2 \\
<2 \\
<2 \\
<2 \\
<2 \\
<2 \\
<2 \\
<2 \\
<2 \\
<2 \\
<2\end{array}$ & $\begin{array}{l}18 \\
23 \\
20 \\
17 \\
18 \\
22 \\
19 \\
19 \\
18 \\
15 \\
19 \\
22 \\
23 \\
19 \\
20 \\
17 \\
19\end{array}$ & $\begin{array}{r}77 \\
92 \\
84 \\
140 \\
120 \\
150 \\
140 \\
150 \\
140 \\
140 \\
110 \\
140 \\
170 \\
130 \\
98 \\
100 \\
120\end{array}$ & $\begin{array}{l}.06 \\
.07 \\
.06 \\
.07 \\
.06 \\
.08 \\
.07 \\
.06 \\
.06 \\
.05 \\
.06 \\
.06 \\
.07 \\
.06 \\
.06 \\
.06 \\
.06\end{array}$ \\
\hline 12 & $\begin{array}{r}.2 \\
.8 \\
1.4 \\
2.0 \\
2.3 \\
3.5 \\
5.3 \\
6.2 \\
7.2 \\
8.2 \\
9.0\end{array}$ & $\begin{array}{l}22 \\
23 \\
23 \\
20 \\
20 \\
18 \\
24 \\
23 \\
22 \\
24 \\
17\end{array}$ & $\begin{array}{l}19 \\
16 \\
18 \\
15 \\
15 \\
14 \\
15 \\
14 \\
12 \\
14 \\
13\end{array}$ & $\begin{array}{l}59 \\
68 \\
66 \\
51 \\
48 \\
46 \\
70 \\
66 \\
60 \\
73 \\
31\end{array}$ & $\begin{array}{l}1.4 \\
1.4 \\
1.5 \\
1.4 \\
1.5 \\
3.0 \\
2.6 \\
2.4 \\
2.3 \\
2.4 \\
1.3\end{array}$ & $\begin{array}{l}510 \\
550 \\
560 \\
570 \\
530 \\
590 \\
660 \\
610 \\
570 \\
610 \\
480\end{array}$ & $\begin{array}{l}<2 \\
<2 \\
<2 \\
<2 \\
<2 \\
<2 \\
<2 \\
<2 \\
<2 \\
<2 \\
<2\end{array}$ & $\begin{array}{l}21 \\
19 \\
20 \\
17 \\
16 \\
15 \\
21 \\
22 \\
20 \\
22 \\
15\end{array}$ & $\begin{array}{r}80 \\
82 \\
88 \\
87 \\
100 \\
260 \\
160 \\
140 \\
140 \\
150 \\
88\end{array}$ & $\begin{array}{l}.06 \\
.06 \\
.07 \\
.06 \\
.06 \\
.06 \\
.07 \\
.07 \\
.06 \\
.07 \\
.05\end{array}$ \\
\hline M5 & $\begin{array}{r}.2 \\
.7 \\
1.0 \\
1.5 \\
2.0 \\
2.2\end{array}$ & $\begin{array}{l}22 \\
26 \\
30 \\
27 \\
25 \\
30\end{array}$ & $\begin{array}{l}16 \\
20 \\
17 \\
15 \\
14 \\
16\end{array}$ & $\begin{array}{l}39 \\
63 \\
82 \\
77 \\
64 \\
86\end{array}$ & $\begin{array}{l}1.0 \\
1.4 \\
1.7 \\
1.7 \\
1.6 \\
2.0\end{array}$ & $\begin{array}{l}440 \\
530 \\
590 \\
560 \\
560 \\
610\end{array}$ & $\begin{array}{l}<2 \\
<2 \\
<2 \\
<2 \\
<2 \\
<2\end{array}$ & $\begin{array}{l}16 \\
19 \\
23 \\
20 \\
20 \\
23\end{array}$ & $\begin{array}{r}61 \\
75 \\
93 \\
95 \\
95 \\
110\end{array}$ & $\begin{array}{l}.05 \\
.06 \\
.07 \\
.06 \\
.06 \\
.07\end{array}$ \\
\hline
\end{tabular}


Table 5. Chemical analysis of drilling-core samples--Continued

\begin{tabular}{|c|c|c|c|c|c|c|c|c|c|}
\hline $\begin{array}{l}\text { Cluster } \\
\text { site }\end{array}$ & $\begin{array}{c}\text { Sample } \\
\text { depth } \\
\text { (m) }\end{array}$ & $\begin{array}{c}\text { Potassium } \\
\text { (percent) }\end{array}$ & $\begin{array}{l}\text { Scandium } \\
(\mu \mathrm{g} / \mathrm{g})\end{array}$ & $\begin{array}{c}\text { Total } \\
\text { selenium } \\
(\mu \mathrm{g} / \mathrm{g})\end{array}$ & $\begin{array}{c}\text { Soluble } \\
\text { selenium } \\
(\mu \mathrm{g} / \mathrm{g})\end{array}$ & $\begin{array}{c}\text { Residual } \\
\text { selenium } \\
(\mu \mathrm{g} / \mathrm{g})\end{array}$ & $\begin{array}{l}\text { Silver } \\
(\mu \mathrm{g} / \mathrm{g})\end{array}$ & $\begin{array}{c}\text { Sodium } \\
\text { (percent) }\end{array}$ & $\begin{array}{l}\text { Strontium } \\
(\mu \mathrm{g} / \mathrm{g})\end{array}$ \\
\hline \multirow[t]{15}{*}{7} & 0.2 & 1.9 & 11 & 0.8 & 0.02 & 0.78 & $<2$ & 1.1 & 240 \\
\hline & .8 & 1.7 & 16 & .9 & .17 & .73 & $<2$ & 1.2 & 250 \\
\hline & 2.0 & 1.9 & 12 & 1.2 & .33 & .87 & $<2$ & 1.5 & 260 \\
\hline & 3.2 & 1.8 & 16 & .9 & .26 & .64 & $<2$ & 1.2 & 280 \\
\hline & 3.8 & 1.6 & 12 & .7 & .62 & .08 & $<2$ & 1.5 & 280 \\
\hline & 4.7 & 2.0 & 6 & .5 & .46 & .04 & $<2$ & 1.6 & 260 \\
\hline & 5.2 & 1.7 & 17 & .7 & .82 & .00 & $<2$ & 1.1 & 220 \\
\hline & 5.6 & 1.9 & 13 & .6 & .46 & .14 & $<2$ & 1.3 & 250 \\
\hline & 5.9 & 2.2 & 6 & .9 & .38 & .52 & $<2$ & 1.5 & 260 \\
\hline & 6.9 & 2.0 & 8 & 1.1 & .84 & .26 & $<2$ & 1.8 & 290 \\
\hline & 7.2 & 1.8 & 15 & 1.4 & 1.17 & .23 & $<2$ & 1.3 & 410 \\
\hline & 8.4 & 1.8 & 16 & 1.4 & 1.12 & .28 & $<2$ & 1.2 & 270 \\
\hline & 10.5 & 2.0 & 11 & .5 & .19 & .31 & $<2$ & 1.4 & 280 \\
\hline & 11.4 & 2.0 & 12 & .7 & .22 & .48 & $<2$ & 1.4 & 240 \\
\hline & 12.1 & 2.0 & 10 & .5 & .12 & .38 & $<2$ & 1.5 & 260 \\
\hline \multirow[t]{17}{*}{11} & .2 & 2.0 & 11 & .9 & .01 & .89 & $<2$ & 1.1 & 240 \\
\hline & .8 & 1.7 & 15 & 1.0 & .20 & .80 & $<2$ & 1.2 & 250 \\
\hline & 2.0 & 1.9 & 11 & 1.3 & .45 & .85 & $<2$ & 1.7 & 280 \\
\hline & 3.2 & 2.1 & 10 & .5 & .17 & .33 & $<2$ & 1.4 & 280 \\
\hline & 4.3 & 1.9 & 10 & .6 & .36 & .24 & $<2$ & 1.8 & 300 \\
\hline & 5.3 & 1.7 & 17 & .6 & .68 & .00 & $<2$ & 1.1 & 230 \\
\hline & 5.6 & 1.8 & 13 & 1.0 & .52 & .48 & $<2$ & 1.4 & 280 \\
\hline & 5.9 & 1.7 & 12 & 1.2 & .76 & .44 & $<2$ & 1.6 & 300 \\
\hline & 6.2 & 2.0 & 10 & 1.0 & .54 & .46 & $<2$ & 1.6 & 270 \\
\hline & 6.6 & 2.1 & 8 & 1.3 & .74 & .56 & $<2$ & 1.7 & 310 \\
\hline & 6.9 & 1.7 & 10 & 1.7 & .99 & .71 & $<2$ & 1.6 & 550 \\
\hline & 7.8 & 1.6 & 15 & 1.7 & 1.09 & .61 & $<2$ & 1.4 & 270 \\
\hline & 8.7 & 1.7 & 17 & 1.2 & .53 & .68 & $<2$ & 1.2 & 240 \\
\hline & 9.6 & 1.6 & 12 & .9 & -- & -- & $<2$ & 1.5 & 420 \\
\hline & 10.5 & 2.0 & 11 & .6 & .26 & .34 & $<2$ & 1.4 & 260 \\
\hline & 11.4 & 2.0 & 12 & .6 & .16 & .44 & $<2$ & 1.4 & 260 \\
\hline & 11.7 & 2.1 & 12 & .5 & .14 & .36 & $<2$ & 1.4 & 260 \\
\hline \multirow[t]{11}{*}{12} & .2 & 2.0 & 11 & 1.0 & .02 & .98 & $<2$ & 1.1 & 240 \\
\hline & .8 & 1.8 & 13 & 1.0 & .19 & .81 & $<2$ & 1.3 & 240 \\
\hline & 1.4 & 1.9 & 13 & 1.4 & .46 & .94 & $<2$ & 1.4 & 250 \\
\hline & 2.0 & 1.9 & 10 & .9 & .26 & .64 & $<2$ & 1.5 & 250 \\
\hline & 2.3 & 2.0 & 10 & .9 & .40 & .50 & $<2$ & 1.6 & 260 \\
\hline & 3.5 & 1.7 & 10 & .6 & .06 & .54 & $<2$ & 1.6 & 280 \\
\hline & 5.3 & 1.7 & 15 & 1.0 & .67 & .33 & $<2$ & 1.4 & 260 \\
\hline & 6.2 & 1.8 & 14 & .9 & .62 & .28 & $<2$ & 1.4 & 270 \\
\hline & 7.2 & 1.8 & 12 & 1.7 & 1.39 & .31 & $<2$ & 1.5 & 320 \\
\hline & 8.2 & 1.7 & 16 & 1.0 & .60 & .40 & $<2$ & 1.2 & 250 \\
\hline & 9.0 & 2.3 & 7 & .6 & .38 & .22 & $<2$ & 1.7 & 270 \\
\hline \multirow[t]{6}{*}{ M5 } & .2 & 2.2 & 9 & .8 & .01 & .79 & $<2$ & 1.3 & 230 \\
\hline & .7 & 2.0 & 13 & 1.1 & .01 & 1.09 & $<2$ & 1.2 & 240 \\
\hline & 1.0 & 1.8 & 17 & 1.0 & .09 & .91 & $<2$ & 1.1 & 230 \\
\hline & 1.5 & 1.9 & 16 & .9 & .12 & .78 & $<2$ & 1.2 & 230 \\
\hline & 2.0 & 2.0 & 14 & .8 & .09 & .71 & $<2$ & 1.2 & 230 \\
\hline & 2.2 & 1.8 & 18 & .8 & .05 & .75 & $<2$ & 1.0 & 240 \\
\hline
\end{tabular}


Table 5. Chemical analysis of driling-core samples--Continued

\begin{tabular}{|c|c|c|c|c|c|c|c|c|c|c|}
\hline $\begin{array}{l}\text { Cluster } \\
\text { site }\end{array}$ & $\begin{array}{c}\text { Sample } \\
\text { depth } \\
\text { (m) }\end{array}$ & $\begin{array}{c}\text { Thorium } \\
(\mu \mathrm{g} / \mathrm{g})\end{array}$ & $\begin{array}{c}\text { Titanium } \\
(\mu \mathrm{g} / \mathrm{g})\end{array}$ & $\begin{array}{c}\text { Tin } \\
\text { (percent) }\end{array}$ & $\begin{array}{l}\text { Vanadium } \\
(\mu \mathrm{g} / \mathrm{g})\end{array}$ & $\begin{array}{c}\text { Yttrium } \\
(\mu \mathrm{g} / \mathrm{g})\end{array}$ & $\begin{array}{l}\text { Zinc } \\
(\mu \mathrm{g} / \mathrm{g})\end{array}$ & $\begin{array}{c}\text { Total } \\
\text { carbon } \\
\text { (percent) }\end{array}$ & $\begin{array}{c}\text { Organic } \\
\text { carbon } \\
\text { (percent) }\end{array}$ & $\begin{array}{c}\text { Carbonate } \\
\text { (percent) }\end{array}$ \\
\hline \multirow[t]{15}{*}{7} & 0.2 & 9 & 0.31 & $<20$ & 110 & 14 & 99 & 1.05 & 0.80 & 0.25 \\
\hline & .8 & 13 & .40 & $<20$ & 150 & 16 & 130 & .81 & .42 & .39 \\
\hline & 2.0 & 10 & .32 & $<20$ & 110 & 14 & 94 & .49 & .20 & .29 \\
\hline & 3.2 & 11 & .41 & $<20$ & 140 & 17 & 120 & .53 & .17 & .36 \\
\hline & 3.8 & 8 & .36 & $<20$ & 110 & 16 & 91 & .48 & .14 & .34 \\
\hline & 4.7 & 5 & .22 & $<20$ & 54 & 11 & 44 & .23 & .04 & .19 \\
\hline & 5.2 & 12 & .40 & $<20$ & 150 & 17 & 120 & .42 & .13 & .29 \\
\hline & 5.6 & 9 & .32 & $<20$ & 110 & 14 & 89 & .42 & .14 & .28 \\
\hline & 5.9 & 6 & .21 & $<20$ & 57 & 10 & 46 & .19 & .01 & .18 \\
\hline & 6.9 & 7 & .26 & $<20$ & 75 & 13 & 62 & .24 & .08 & .16 \\
\hline & 7.2 & 12 & .38 & $<20$ & 130 & 17 & 110 & .39 & .13 & .26 \\
\hline & 8.4 & 12 & .38 & $<20$ & 140 & 16 & 120 & .37 & .13 & .24 \\
\hline & 10.5 & 9 & .29 & $<20$ & 98 & 13 & 79 & .44 & .10 & .34 \\
\hline & 11.4 & 10 & .32 & $<20$ & 110 & 14 & 93 & .13 & .06 & .07 \\
\hline & 12.1 & 9 & .29 & $<20$ & 93 & 14 & 82 & .16 & .02 & .14 \\
\hline \multirow[t]{17}{*}{11} & .2 & 10 & .31 & $<20$ & 110 & 14 & 96 & .95 & .69 & .26 \\
\hline & .8 & 14 & .38 & $<20$ & 140 & 16 & 120 & .71 & .33 & .38 \\
\hline & 2.0 & 11 & .33 & $<20$ & 110 & 15 & 95 & .52 & .21 & .31 \\
\hline & 3.2 & 10 & .28 & $<20$ & 92 & 12 & 76 & .40 & .11 & .29 \\
\hline & 4.3 & 11 & .32 & $<20$ & 93 & 15 & 78 & .42 & .11 & .31 \\
\hline & 5.3 & 13 & .39 & $<20$ & 150 & 17 & 120 & .48 & .17 & .31 \\
\hline & 5.6 & 10 & .36 & $<20$ & 120 & 16 & 97 & .50 & .15 & .35 \\
\hline & 5.9 & 10 & .33 & $<20$ & 100 & 15 & 83 & .52 & .22 & .30 \\
\hline & 6.2 & 8 & .29 & $<20$ & 91 & 13 & 74 & .33 & .11 & .22 \\
\hline & 6.6 & 7 & .26 & $<20$ & 77 & 12 & 65 & .24 & .07 & .17 \\
\hline & 6.9 & 9 & .32 & $<20$ & 95 & 14 & 79 & .27 & .08 & .19 \\
\hline & 7.8 & 11 & .38 & $<20$ & 130 & 16 & 100 & .48 & .14 & .34 \\
\hline & 8.7 & 13 & .39 & $<20$ & 150 & 17 & 120 & .41 & .12 & .29 \\
\hline & 9.6 & 9 & .34 & $<20$ & 110 & 15 & 92 & .46 & .12 & .34 \\
\hline & 10.5 & 11 & .30 & $<20$ & 100 & 14 & 86 & .28 & .04 & .24 \\
\hline & 11.4 & 9 & .32 & $<20$ & 110 & 14 & 91 & .14 & .05 & .09 \\
\hline & 11.7 & 9 & .31 & $<20$ & 100 & 14 & 86 & .10 & .05 & .05 \\
\hline \multirow[t]{11}{*}{12} & .2 & 12 & .31 & $<20$ & 110 & 14 & 99 & 1.08 & .82 & .26 \\
\hline & .8 & 12 & .34 & $<20$ & 120 & 15 & 110 & .72 & .39 & .33 \\
\hline & 1.4 & 12 & .34 & $<20$ & 120 & 15 & 110 & .56 & .26 & .30 \\
\hline & 2.0 & 10 & .29 & $<20$ & 97 & 14 & 90 & .36 & .13 & .23 \\
\hline & 2.3 & 9 & .30 & $<20$ & 92 & 13 & 77 & .47 & .11 & .36 \\
\hline & 3.5 & 8 & .28 & $<20$ & 89 & 13 & 70 & .57 & .14 & .43 \\
\hline & 5.3 & 11 & .38 & $<20$ & 140 & 16 & 110 & .43 & .13 & .30 \\
\hline & 6.2 & 12 & .36 & $<20$ & 130 & 16 & 100 & .32 & .11 & .21 \\
\hline & 7.2 & 10 & .33 & $<20$ & 110 & 15 & 90 & .39 & .09 & .30 \\
\hline & 8.2 & 13 & .37 & $<20$ & 140 & 16 & 110 & .43 & .10 & .33 \\
\hline & 9.0 & 7 & .21 & $<20$ & 60 & 11 & 53 & .12 & .02 & .10 \\
\hline \multirow[t]{6}{*}{ M5 } & .2 & 8 & .24 & $<10$ & 76 & 12 & 74 & .67 & .47 & .20 \\
\hline & .7 & 10 & .33 & $<10$ & 120 & 16 & 100 & .79 & .41 & .38 \\
\hline & 1.0 & 14 & .40 & $<10$ & 160 & 18 & 130 & .77 & .37 & .40 \\
\hline & 1.5 & 13 & .37 & $<10$ & 150 & 17 & 120 & .65 & .29 & .36 \\
\hline & 2.0 & 11 & .32 & $<10$ & 120 & 15 & 100 & .46 & .22 & .24 \\
\hline & 2.2 & 14 & .40 & $<10$ & 160 & 18 & 130 & .69 & .30 & .39 \\
\hline
\end{tabular}


Table 5. Chemical analysis of drilling-core samples--Continued

\begin{tabular}{|c|c|c|c|c|c|c|c|c|c|c|}
\hline $\begin{array}{l}\text { Cluster } \\
\text { site }\end{array}$ & $\begin{array}{l}\text { Sample } \\
\text { depth } \\
\text { (m) }\end{array}$ & $\begin{array}{c}\text { Aluminum } \\
\text { (percent) }\end{array}$ & $\begin{array}{c}\text { Arsenic } \\
(\mu \mathrm{g} / \mathrm{g})\end{array}$ & $\begin{array}{c}\text { Barium } \\
(\mu \mathrm{g} / \mathrm{g})\end{array}$ & $\begin{array}{l}\text { Calcium } \\
\text { (percent) }\end{array}$ & $\begin{array}{c}\text { Cerium } \\
(\mu \mathrm{g} / \mathrm{g})\end{array}$ & $\begin{array}{l}\text { Chromium } \\
\quad(\mu \mathrm{g} / \mathrm{g})\end{array}$ & $\begin{array}{l}\text { Cobalt } \\
(\mu \mathrm{g} / \mathrm{g})\end{array}$ & $\begin{array}{l}\text { Copper } \\
(\mu \mathrm{g} / \mathrm{g})\end{array}$ & $\begin{array}{c}\text { Iron } \\
\text { (percent) }\end{array}$ \\
\hline M5 & $\begin{array}{r}2.5 \\
3.0 \\
3.7 \\
4.5 \\
5.1 \\
5.3 \\
5.5 \\
6.4 \\
7.5 \\
8.0 \\
8.4 \\
8.8 \\
9.3 \\
9.6 \\
10.0 \\
10.3 \\
10.6 \\
10.8 \\
11.4 \\
12.1 \\
12.9 \\
13.3 \\
13.5 \\
13.7 \\
14.1 \\
14.6 \\
15.2 \\
15.7\end{array}$ & $\begin{array}{r}6.2 \\
6.6 \\
7.8 \\
6.3 \\
7.1 \\
7.7 \\
5.1 \\
8.3 \\
7.1 \\
6.8 \\
8.5 \\
7.8 \\
8.5 \\
12.0 \\
6.4 \\
6.3 \\
7.1 \\
7.9 \\
6.5 \\
5.3 \\
5.0 \\
6.3 \\
5.2 \\
6.7 \\
6.7 \\
7.8 \\
7.7 \\
7.5\end{array}$ & $\begin{array}{r}7.7 \\
7.9 \\
8.6 \\
6.8 \\
8.2 \\
10.0 \\
5.8 \\
8.7 \\
7.8 \\
7.9 \\
8.7 \\
9.0 \\
9.8 \\
8.0 \\
8.3 \\
7.1 \\
9.0 \\
10.0 \\
7.60 \\
5.90 \\
6.60 \\
6.50 \\
3.90 \\
6.90 \\
8.50 \\
10.00 \\
9.20 \\
6.70\end{array}$ & $\begin{array}{r}960 \\
1,100 \\
850 \\
890 \\
870 \\
900 \\
160 \\
770 \\
260 \\
530 \\
700 \\
850 \\
750 \\
1,500 \\
1,100 \\
990 \\
910 \\
115 \\
980 \\
130 \\
880 \\
820 \\
770 \\
880 \\
740 \\
390 \\
790 \\
370\end{array}$ & $\begin{array}{l}3.7 \\
2.0 \\
2.7 \\
2.2 \\
3.0 \\
2.1 \\
3.6 \\
2.5 \\
3.8 \\
2.9 \\
2.8 \\
2.4 \\
2.5 \\
2.7 \\
2.0 \\
1.7 \\
2.8 \\
3.5 \\
1.9 \\
2.5 \\
1.6 \\
1.9 \\
2.2 \\
1.5 \\
3.3 \\
4.8 \\
3.6 \\
4.5\end{array}$ & $\begin{array}{l}35 \\
34 \\
44 \\
33 \\
42 \\
49 \\
26 \\
48 \\
43 \\
36 \\
47 \\
44 \\
45 \\
62 \\
32 \\
30 \\
38 \\
42 \\
32 \\
25 \\
25 \\
29 \\
24 \\
31 \\
36 \\
41 \\
42 \\
41\end{array}$ & $\begin{array}{r}130 \\
140 \\
170 \\
220 \\
170 \\
90 \\
130 \\
200 \\
160 \\
140 \\
200 \\
140 \\
190 \\
220 \\
110 \\
100 \\
120 \\
140 \\
130 \\
120 \\
190 \\
120 \\
84 \\
160 \\
150 \\
210 \\
160 \\
200\end{array}$ & $\begin{array}{r}15 \\
15 \\
18 \\
21 \\
18 \\
13 \\
11 \\
20 \\
18 \\
16 \\
22 \\
20 \\
21 \\
29 \\
14 \\
13 \\
17 \\
17 \\
14 \\
10 \\
12 \\
13 \\
8 \\
15 \\
15 \\
21 \\
19 \\
20\end{array}$ & $\begin{array}{l}25 \\
26 \\
39 \\
27 \\
32 \\
28 \\
15 \\
46 \\
33 \\
30 \\
47 \\
35 \\
42 \\
44 \\
21 \\
19 \\
29 \\
40 \\
23 \\
14 \\
14 \\
21 \\
11 \\
23 \\
25 \\
42 \\
34 \\
37\end{array}$ & $\begin{array}{l}2.7 \\
3.0 \\
4.2 \\
3.1 \\
3.6 \\
3.4 \\
2.0 \\
4.7 \\
3.7 \\
3.3 \\
4.9 \\
3.8 \\
4.5 \\
5.1 \\
2.5 \\
2.3 \\
3.3 \\
3.9 \\
2.8 \\
2.0 \\
2.0 \\
2.5 \\
1.5 \\
2.8 \\
3.0 \\
4.3 \\
3.9 \\
3.9\end{array}$ \\
\hline M10 & $\begin{array}{r}.5 \\
1.0 \\
1.2 \\
2.0 \\
3.0 \\
3.4 \\
3.7 \\
4.1 \\
4.6 \\
5.1 \\
5.5 \\
5.9 \\
6.3 \\
6.7 \\
7.1 \\
7.5 \\
7.9 \\
8.2 \\
8.5 \\
9.2 \\
9.8 \\
10.1\end{array}$ & $\begin{array}{l}7.8 \\
5.9 \\
5.6 \\
8.2 \\
7.6 \\
7.6 \\
8.3 \\
7.8 \\
6.5 \\
6.8 \\
7.8 \\
8.6 \\
6.9 \\
7.9 \\
8.1 \\
7.2 \\
7.0 \\
7.0 \\
8.3 \\
5.9 \\
5.6 \\
6.6\end{array}$ & $\begin{array}{r}8.90 \\
8.60 \\
6.70 \\
8.50 \\
8.20 \\
10.00 \\
8.60 \\
7.70 \\
6.40 \\
6.80 \\
8.50 \\
8.30 \\
7.30 \\
8.40 \\
8.20 \\
6.20 \\
10.00 \\
8.70 \\
9.50 \\
6.40 \\
7.00 \\
8.30\end{array}$ & $\begin{array}{r}980 \\
1,500 \\
2,500 \\
910 \\
900 \\
1,000 \\
810 \\
950 \\
1,000 \\
1,100 \\
870 \\
750 \\
1,000 \\
950 \\
810 \\
810 \\
960 \\
850 \\
660 \\
1,000 \\
1,300 \\
980\end{array}$ & $\begin{array}{l}2.2 \\
1.8 \\
1.7 \\
2.1 \\
2.1 \\
4.0 \\
3.2 \\
2.8 \\
2.2 \\
1.9 \\
3.3 \\
2.9 \\
2.4 \\
2.9 \\
3.2 \\
2.5 \\
3.0 \\
2.7 \\
3.1 \\
2.0 \\
1.9 \\
2.2\end{array}$ & $\begin{array}{l}42 \\
35 \\
54 \\
47 \\
41 \\
41 \\
46 \\
43 \\
35 \\
38 \\
42 \\
45 \\
38 \\
44 \\
46 \\
41 \\
39 \\
41 \\
47 \\
34 \\
33 \\
37\end{array}$ & $\begin{array}{l}130 \\
100 \\
140 \\
130 \\
120 \\
150 \\
160 \\
170 \\
180 \\
130 \\
200 \\
220 \\
120 \\
170 \\
160 \\
130 \\
170 \\
160 \\
200 \\
120 \\
110 \\
140\end{array}$ & $\begin{array}{l}15 \\
10 \\
12 \\
16 \\
16 \\
18 \\
16 \\
18 \\
19 \\
16 \\
21 \\
22 \\
17 \\
19 \\
19 \\
17 \\
18 \\
17 \\
21 \\
13 \\
14 \\
16\end{array}$ & $\begin{array}{l}35 \\
20 \\
15 \\
37 \\
33 \\
36 \\
41 \\
35 \\
23 \\
23 \\
37 \\
46 \\
26 \\
39 \\
39 \\
28 \\
34 \\
32 \\
45 \\
20 \\
17 \\
27\end{array}$ & $\begin{array}{l}3.5 \\
2.5 \\
2.6 \\
3.9 \\
3.6 \\
3.6 \\
4.3 \\
3.7 \\
2.9 \\
2.7 \\
4.0 \\
4.6 \\
2.9 \\
4.0 \\
4.1 \\
3.2 \\
3.5 \\
3.5 \\
4.7 \\
2.5 \\
2.3 \\
3.1\end{array}$ \\
\hline
\end{tabular}


Table 5. Chemical analysis of drilling-core samples--Continued

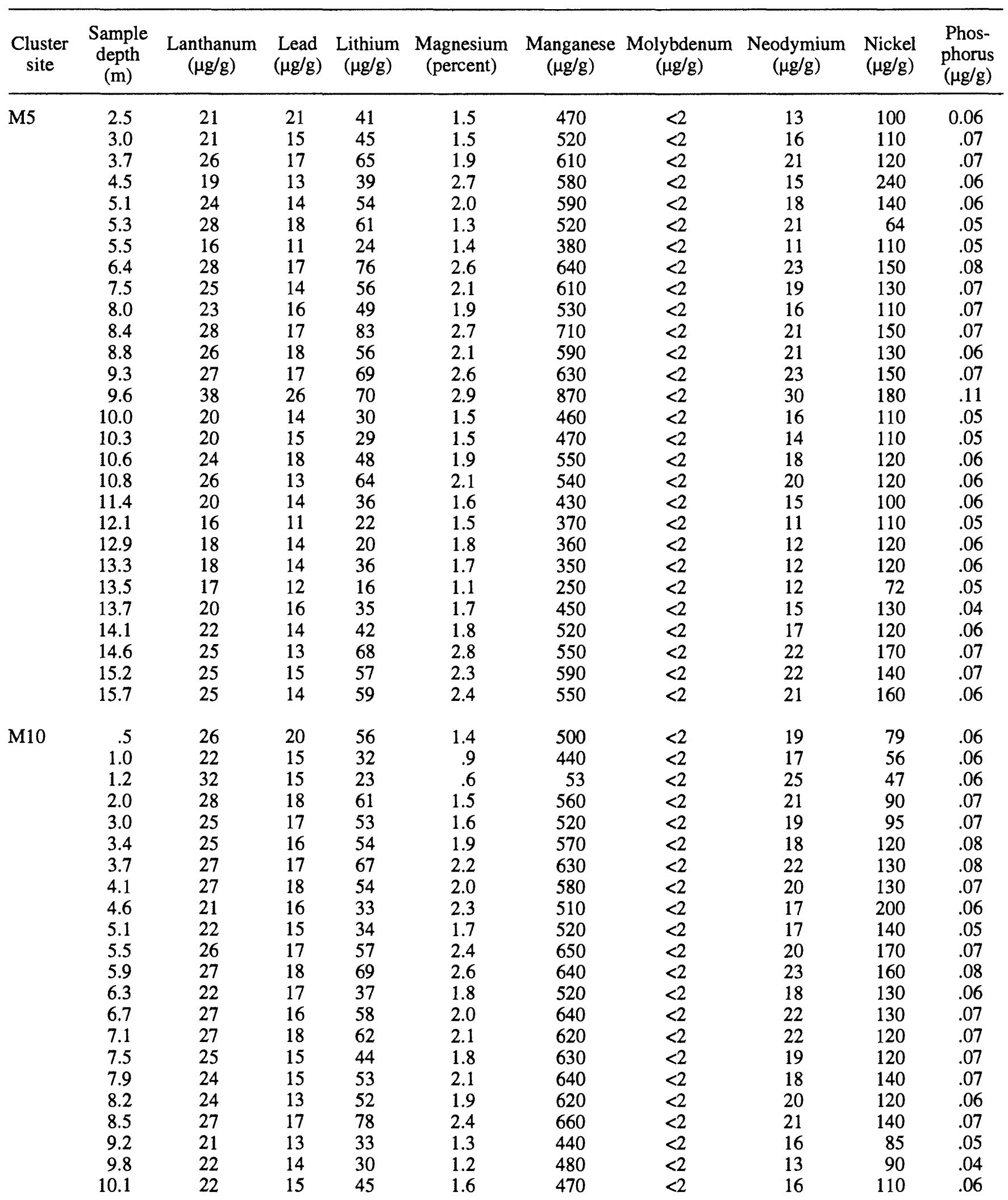


Table 5. Chemical analysis of drilling-core samples--Continued

\begin{tabular}{|c|c|c|c|c|c|c|c|c|c|}
\hline $\begin{array}{l}\text { Cluster } \\
\text { site }\end{array}$ & $\begin{array}{l}\text { Sample } \\
\text { depth } \\
\text { (m) }\end{array}$ & $\begin{array}{c}\text { Potassium } \\
\text { (percent) }\end{array}$ & $\begin{array}{c}\text { Scandium } \\
(\mu \mathrm{g} / \mathrm{g})\end{array}$ & $\begin{array}{c}\text { Total } \\
\text { selenium } \\
(\mu \mathrm{g} / \mathrm{g})\end{array}$ & $\begin{array}{c}\text { Soluble } \\
\text { selenium } \\
(\mu \mathrm{g} / \mathrm{g})\end{array}$ & $\begin{array}{c}\text { Residual } \\
\text { selenium } \\
(\mu \mathrm{g} / \mathrm{g})\end{array}$ & $\begin{array}{l}\text { Silver } \\
(\mu \mathrm{g} / \mathrm{g})\end{array}$ & $\begin{array}{c}\text { Sodium } \\
\text { (percent) }\end{array}$ & $\begin{array}{l}\text { Strontium } \\
(\mu \mathrm{g} / \mathrm{g})\end{array}$ \\
\hline M5 & $\begin{array}{r}2.5 \\
3.0 \\
3.7 \\
4.5 \\
5.1 \\
5.3 \\
5.5 \\
6.4 \\
7.5 \\
8.0 \\
8.4 \\
8.8 \\
9.3 \\
9.6 \\
10.0 \\
10.3 \\
10.6 \\
10.8 \\
11.4 \\
12.1 \\
12.9 \\
13.3 \\
13.5 \\
13.7 \\
14.1 \\
14.6 \\
15.2 \\
15.7\end{array}$ & $\begin{array}{l}2.0 \\
2.1 \\
1.8 \\
1.9 \\
1.9 \\
2.3 \\
2.0 \\
1.8 \\
1.8 \\
1.9 \\
1.7 \\
1.9 \\
1.8 \\
3.9 \\
2.3 \\
2.3 \\
1.9 \\
1.8 \\
2.2 \\
2.3 \\
2.3 \\
2.3 \\
2.3 \\
2.2 \\
1.8 \\
1.6 \\
1.8 \\
1.6\end{array}$ & $\begin{array}{r}10 \\
11 \\
15 \\
10 \\
13 \\
12 \\
7 \\
18 \\
13 \\
12 \\
18 \\
14 \\
17 \\
18 \\
8 \\
8 \\
11 \\
14 \\
10 \\
7 \\
6 \\
6 \\
5 \\
10 \\
11 \\
17 \\
15 \\
15\end{array}$ & $\begin{array}{r}0.7 \\
.7 \\
.7 \\
.5 \\
.7 \\
.7 \\
.7 \\
.9 \\
1.2 \\
.8 \\
.8 \\
.8 \\
.8 \\
.8 \\
.7 \\
.5 \\
.7 \\
.7 \\
.7 \\
.5 \\
.5 \\
.5 \\
.4 \\
.4 \\
.6 \\
.6 \\
.7 \\
.5\end{array}$ & $\begin{array}{r}0.01 \\
.01 \\
.02 \\
.03 \\
.05 \\
.08 \\
.06 \\
.40 \\
1.07 \\
.46 \\
.17 \\
.24 \\
.26 \\
.19 \\
.09 \\
.06 \\
.04 \\
.04 \\
.03 \\
.02 \\
.02 \\
.03 \\
.06 \\
.03 \\
.04 \\
.06 \\
.12 \\
.09\end{array}$ & $\begin{array}{r}0.69 \\
.69 \\
.68 \\
.47 \\
.65 \\
.62 \\
.63 \\
.50 \\
.13 \\
.34 \\
.63 \\
.56 \\
.54 \\
.61 \\
.61 \\
.44 \\
.66 \\
.66 \\
.67 \\
.48 \\
.48 \\
.47 \\
.34 \\
.37 \\
.56 \\
.54 \\
.58 \\
.41\end{array}$ & $\begin{array}{l}<2 \\
<2 \\
<2 \\
<2 \\
<2 \\
<2 \\
<2 \\
<2 \\
<2 \\
<2 \\
<2 \\
<2 \\
<2 \\
<2 \\
<2 \\
<2 \\
<2 \\
<2 \\
<2 \\
<2 \\
<2 \\
<2 \\
<2 \\
<2 \\
<2 \\
<2 \\
<2 \\
<2 \\
<2 \\
<2\end{array}$ & $\begin{array}{l}1.6 \\
1.5 \\
1.3 \\
1.7 \\
1.4 \\
1.7 \\
1.5 \\
1.4 \\
1.7 \\
1.8 \\
1.2 \\
1.7 \\
1.4 \\
2.9 \\
1.8 \\
1.7 \\
1.7 \\
1.4 \\
1.4 \\
1.4 \\
1.4 \\
1.4 \\
1.6 \\
1.6 \\
1.6 \\
1.2 \\
1.5 \\
1.4\end{array}$ & $\begin{array}{l}290 \\
250 \\
250 \\
260 \\
280 \\
280 \\
260 \\
240 \\
310 \\
290 \\
250 \\
320 \\
270 \\
460 \\
280 \\
260 \\
290 \\
360 \\
270 \\
290 \\
240 \\
240 \\
370 \\
260 \\
320 \\
560 \\
610 \\
460\end{array}$ \\
\hline M10 & $\begin{array}{r}.5 \\
1.0 \\
1.2 \\
2.0 \\
3.0 \\
3.4 \\
3.7 \\
4.1 \\
4.6 \\
5.1 \\
5.5 \\
5.9 \\
6.3 \\
6.7 \\
7.1 \\
7.5 \\
7.9 \\
8.2 \\
8.5 \\
9.2 \\
9.8 \\
10.1\end{array}$ & $\begin{array}{l}2.2 \\
2.2 \\
2.2 \\
2.0 \\
2.1 \\
2.0 \\
1.8 \\
2.0 \\
2.2 \\
2.2 \\
1.8 \\
1.9 \\
2.0 \\
1.8 \\
1.8 \\
2.2 \\
1.9 \\
1.8 \\
1.8 \\
2.2 \\
2.2 \\
1.9\end{array}$ & $\begin{array}{r}16 \\
8 \\
8 \\
14 \\
13 \\
13 \\
16 \\
14 \\
9 \\
9 \\
14 \\
17 \\
10 \\
14 \\
15 \\
12 \\
12 \\
13 \\
18 \\
9 \\
8 \\
11\end{array}$ & $\begin{array}{r}.9 \\
.6 \\
.6 \\
.8 \\
.8 \\
1.0 \\
.9 \\
.7 \\
.5 \\
.5 \\
.6 \\
.7 \\
.6 \\
.7 \\
.6 \\
.5 \\
.7 \\
.6 \\
.7 \\
.4 \\
.5 \\
.6\end{array}$ & $\begin{array}{l}.02 \\
.01 \\
.00 \\
.01 \\
.01 \\
.02 \\
.18 \\
.01 \\
.01 \\
.03 \\
.04 \\
.04 \\
.05 \\
.09 \\
-- \\
-- \\
.05 \\
.10 \\
.07 \\
.06 \\
.05 \\
.09\end{array}$ & $\begin{array}{l}.88 \\
.59 \\
.60 \\
.79 \\
.79 \\
.98 \\
.72 \\
.69 \\
.49 \\
.47 \\
.56 \\
.66 \\
.55 \\
.61 \\
-- \\
-- \\
.65 \\
.50 \\
.63 \\
.34 \\
.45 \\
.51\end{array}$ & $\begin{array}{l}<2 \\
<2 \\
<2 \\
<2 \\
<2 \\
<2 \\
<2 \\
<2 \\
<2 \\
<2 \\
<2 \\
<2 \\
<2 \\
<2 \\
<2 \\
<2 \\
<2 \\
<2 \\
<2 \\
<2 \\
<2 \\
<2 \\
<2 \\
<2\end{array}$ & $\begin{array}{l}1.2 \\
1.3 \\
1.5 \\
1.2 \\
1.2 \\
1.3 \\
1.1 \\
1.4 \\
1.7 \\
1.8 \\
1.6 \\
1.2 \\
1.8 \\
1.6 \\
1.5 \\
1.6 \\
1.7 \\
1.7 \\
1.1 \\
1.6 \\
1.5 \\
1.6\end{array}$ & $\begin{array}{l}240 \\
230 \\
260 \\
240 \\
240 \\
290 \\
260 \\
280 \\
260 \\
270 \\
290 \\
270 \\
310 \\
350 \\
320 \\
280 \\
300 \\
280 \\
260 \\
250 \\
250 \\
250\end{array}$ \\
\hline
\end{tabular}


Table 5. Chemical analysis of drilling-core samples--Continued

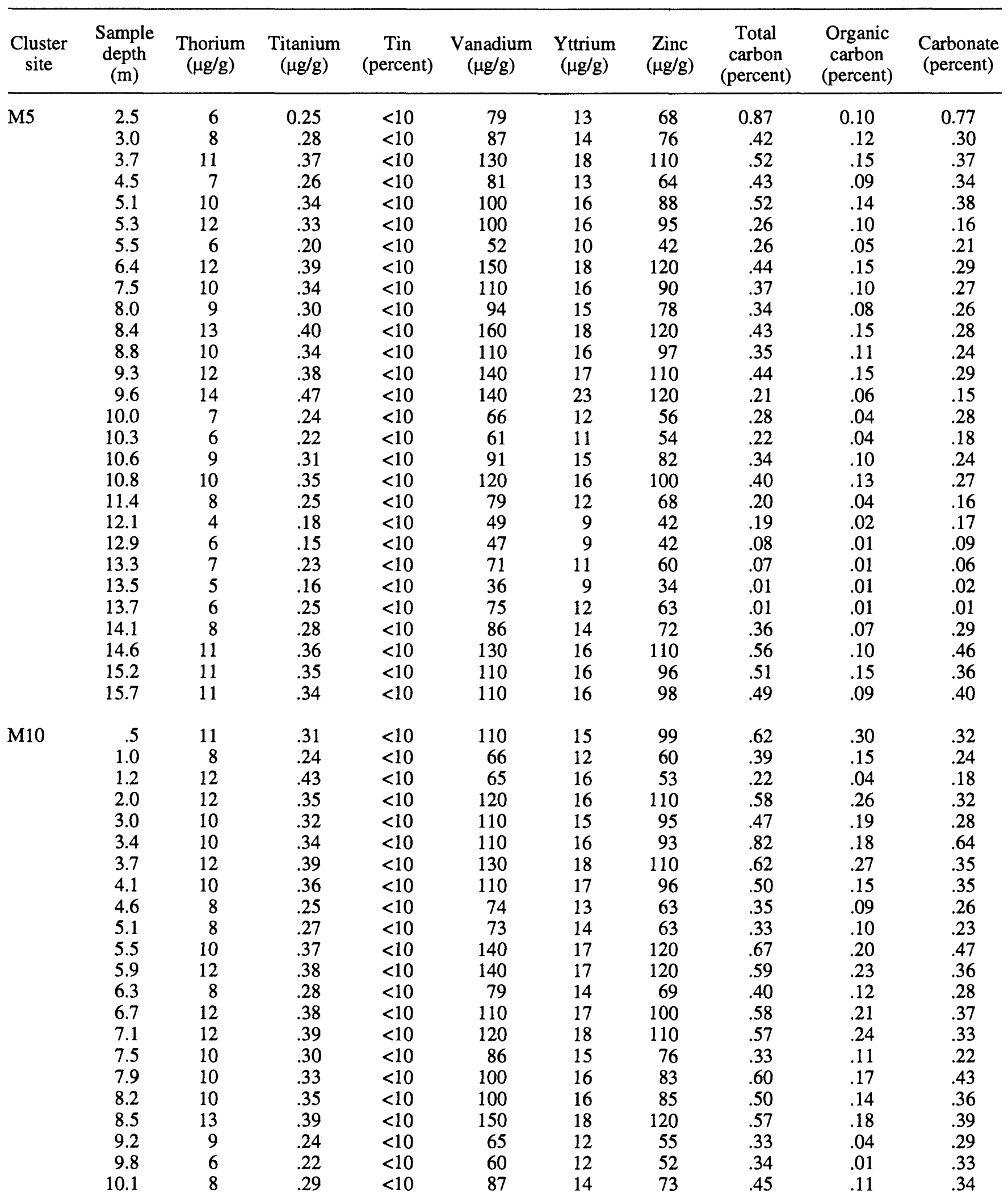


Table 5. Chemical analysis of drilling-core samples--Continued

\begin{tabular}{|c|c|c|c|c|c|c|c|c|c|c|}
\hline $\begin{array}{l}\text { Cluster } \\
\text { site }\end{array}$ & $\begin{array}{c}\text { Sample } \\
\text { depth } \\
\text { (m) }\end{array}$ & $\underset{\text { (percent) }}{\text { Aluminum }}$ & $\begin{array}{c}\text { Arsenic } \\
(\mu \mathrm{g} / \mathrm{g})\end{array}$ & $\begin{array}{c}\text { Barium } \\
(\mu \mathrm{g} / \mathrm{g})\end{array}$ & $\begin{array}{c}\text { Calcium } \\
\text { (percent) }\end{array}$ & $\begin{array}{l}\text { Cerium } \\
(\mu \mathrm{g} / \mathrm{g})\end{array}$ & $\begin{array}{c}\text { Chromium } \\
(\mu \mathrm{g} / \mathrm{g})\end{array}$ & $\begin{array}{l}\text { Cobalt } \\
(\mu \mathrm{g} / \mathrm{g})\end{array}$ & $\begin{array}{l}\text { Copper } \\
(\mu \mathrm{g} / \mathrm{g})\end{array}$ & $\begin{array}{c}\text { Iron } \\
\text { (percent) }\end{array}$ \\
\hline M10 & $\begin{array}{l}10.3 \\
10.7 \\
11.5 \\
12.4 \\
13.2 \\
13.5 \\
13.8 \\
14.0 \\
14.5 \\
15.1 \\
15.5\end{array}$ & $\begin{array}{l}5.8 \\
5.4 \\
4.9 \\
4.2 \\
6.9 \\
6.9 \\
6.0 \\
7.1 \\
7.3 \\
6.8 \\
6.1\end{array}$ & $\begin{array}{l}7.50 \\
7.10 \\
5.70 \\
6.70 \\
7.90 \\
8.80 \\
6.20 \\
7.60 \\
8.70 \\
9.40 \\
7.50\end{array}$ & $\begin{array}{r}1,200 \\
1,200 \\
1,100 \\
1,200 \\
900 \\
980 \\
1,100 \\
410 \\
900 \\
1,000 \\
900\end{array}$ & $\begin{array}{l}1.9 \\
1.6 \\
1.6 \\
2.4 \\
2.3 \\
2.1 \\
1.9 \\
2.3 \\
3.0 \\
2.5 \\
2.6\end{array}$ & $\begin{array}{l}34 \\
31 \\
28 \\
21 \\
41 \\
39 \\
32 \\
41 \\
42 \\
39 \\
32\end{array}$ & $\begin{array}{r}130 \\
130 \\
150 \\
310 \\
130 \\
150 \\
130 \\
79 \\
180 \\
170 \\
200\end{array}$ & $\begin{array}{l}13 \\
12 \\
11 \\
17 \\
14 \\
16 \\
12 \\
11 \\
19 \\
17 \\
16\end{array}$ & $\begin{array}{l}20 \\
16 \\
13 \\
14 \\
27 \\
30 \\
17 \\
21 \\
36 \\
27 \\
21\end{array}$ & $\begin{array}{l}2.6 \\
2.2 \\
2.0 \\
2.5 \\
3.2 \\
3.4 \\
2.4 \\
2.9 \\
3.8 \\
3.3 \\
2.7\end{array}$ \\
\hline NW1 & $\begin{array}{l}1.8 \\
3.7\end{array}$ & $\begin{array}{l}6.6 \\
7.2\end{array}$ & $\begin{array}{l}7.4 \\
8.6\end{array}$ & $\begin{array}{r}1,000 \\
930\end{array}$ & $\begin{array}{l}2.7 \\
2.1\end{array}$ & $\begin{array}{l}32 \\
40\end{array}$ & $\begin{array}{l}150 \\
160\end{array}$ & $\begin{array}{l}14 \\
16\end{array}$ & $\begin{array}{l}25 \\
31\end{array}$ & $\begin{array}{l}3.0 \\
3.5\end{array}$ \\
\hline NW4 & $\begin{array}{l}1.8 \\
3.7\end{array}$ & $\begin{array}{l}7.6 \\
7.0\end{array}$ & $\begin{array}{l}8.5 \\
9.4\end{array}$ & $\begin{array}{l}880 \\
960\end{array}$ & $\begin{array}{l}2.1 \\
2.5\end{array}$ & $\begin{array}{l}42 \\
40\end{array}$ & $\begin{array}{l}160 \\
180\end{array}$ & $\begin{array}{l}15 \\
16\end{array}$ & $\begin{array}{l}35 \\
30\end{array}$ & $\begin{array}{l}3.8 \\
3.5\end{array}$ \\
\hline NW7 & $\begin{array}{l}1.8 \\
3.7\end{array}$ & $\begin{array}{l}7.8 \\
7.4\end{array}$ & $\begin{array}{l}8.5 \\
8.9\end{array}$ & $\begin{array}{l}830 \\
990\end{array}$ & $\begin{array}{l}2.2 \\
2.6\end{array}$ & $\begin{array}{l}43 \\
42\end{array}$ & $\begin{array}{l}190 \\
180\end{array}$ & $\begin{array}{l}16 \\
17\end{array}$ & $\begin{array}{l}37 \\
33\end{array}$ & $\begin{array}{l}4.0 \\
3.7\end{array}$ \\
\hline NW10 & $\begin{array}{l}1.8 \\
3.7\end{array}$ & $\begin{array}{l}8.0 \\
6.3\end{array}$ & $\begin{array}{l}9.4 \\
6.9\end{array}$ & $\begin{array}{r}810 \\
1,000\end{array}$ & $\begin{array}{l}2.4 \\
2.0\end{array}$ & $\begin{array}{l}44 \\
33\end{array}$ & $\begin{array}{l}180 \\
200\end{array}$ & $\begin{array}{l}16 \\
16\end{array}$ & $\begin{array}{l}40 \\
23\end{array}$ & $\begin{array}{l}4.2 \\
3.0\end{array}$ \\
\hline NW13 & $\begin{array}{l}1.8 \\
3.7\end{array}$ & $\begin{array}{l}7.1 \\
6.4\end{array}$ & $\begin{array}{l}6.4 \\
7.1\end{array}$ & $\begin{array}{r}910 \\
1,000\end{array}$ & $\begin{array}{l}2.1 \\
2.3\end{array}$ & $\begin{array}{l}39 \\
34\end{array}$ & $\begin{array}{l}160 \\
170\end{array}$ & $\begin{array}{l}14 \\
15\end{array}$ & $\begin{array}{l}30 \\
24\end{array}$ & $\begin{array}{l}3.4 \\
2.9\end{array}$ \\
\hline SE1 & $\begin{array}{r}.9 \\
1.5\end{array}$ & $\begin{array}{l}7.1 \\
7.0\end{array}$ & $\begin{array}{l}8.5 \\
8.1\end{array}$ & $\begin{array}{l}960 \\
910\end{array}$ & $\begin{array}{l}2.6 \\
2.0\end{array}$ & $\begin{array}{l}40 \\
36\end{array}$ & $\begin{array}{l}150 \\
150\end{array}$ & $\begin{array}{l}14 \\
14\end{array}$ & $\begin{array}{l}30 \\
25\end{array}$ & $\begin{array}{l}3.4 \\
3.2\end{array}$ \\
\hline SE4 & $\begin{array}{r}.9 \\
1.5\end{array}$ & $\begin{array}{l}7.1 \\
6.8\end{array}$ & $\begin{array}{l}8.0 \\
8.4\end{array}$ & $\begin{array}{r}1,000 \\
920\end{array}$ & $\begin{array}{l}2.3 \\
2.3\end{array}$ & $\begin{array}{l}39 \\
35\end{array}$ & $\begin{array}{l}140 \\
190\end{array}$ & $\begin{array}{l}14 \\
17\end{array}$ & $\begin{array}{l}30 \\
29\end{array}$ & $\begin{array}{l}3.4 \\
3.3\end{array}$ \\
\hline SE7 & $\begin{array}{r}.9 \\
1.5\end{array}$ & $\begin{array}{l}7.2 \\
7.6\end{array}$ & $\begin{array}{l}7.9 \\
8.7\end{array}$ & $\begin{array}{l}930 \\
860\end{array}$ & $\begin{array}{l}2.0 \\
2.6\end{array}$ & $\begin{array}{l}39 \\
41\end{array}$ & $\begin{array}{l}140 \\
180\end{array}$ & $\begin{array}{l}14 \\
16\end{array}$ & $\begin{array}{l}31 \\
35\end{array}$ & $\begin{array}{l}3.4 \\
4.0\end{array}$ \\
\hline SE10 & $\begin{array}{r}.9 \\
1.5\end{array}$ & $\begin{array}{l}7.4 \\
7.6\end{array}$ & $\begin{array}{l}8.4 \\
8.2\end{array}$ & $\begin{array}{l}940 \\
860\end{array}$ & $\begin{array}{l}2.4 \\
2.9\end{array}$ & $\begin{array}{l}39 \\
43\end{array}$ & $\begin{array}{l}140 \\
180\end{array}$ & $\begin{array}{l}14 \\
17\end{array}$ & $\begin{array}{l}33 \\
37\end{array}$ & $\begin{array}{l}3.5 \\
4.0\end{array}$ \\
\hline SE13 & $\begin{array}{r}.9 \\
1.5\end{array}$ & $\begin{array}{l}6.6 \\
6.9\end{array}$ & $\begin{array}{l}7.6 \\
8.1\end{array}$ & $\begin{array}{r}1,200 \\
960\end{array}$ & $\begin{array}{l}2.1 \\
2.4\end{array}$ & $\begin{array}{l}37 \\
34\end{array}$ & $\begin{array}{l}120 \\
160\end{array}$ & $\begin{array}{l}11 \\
15\end{array}$ & $\begin{array}{l}24 \\
28\end{array}$ & $\begin{array}{l}2.8 \\
3.2\end{array}$ \\
\hline EW2 & $\begin{array}{l}1.2 \\
1.5\end{array}$ & $\begin{array}{l}6.9 \\
6.3\end{array}$ & $\begin{array}{l}8.0 \\
7.0\end{array}$ & $\begin{array}{r}940 \\
1,000\end{array}$ & $\begin{array}{l}4.1 \\
2.2\end{array}$ & $\begin{array}{l}38 \\
33\end{array}$ & $\begin{array}{l}160 \\
180\end{array}$ & $\begin{array}{l}16 \\
13\end{array}$ & $\begin{array}{l}31 \\
22\end{array}$ & $\begin{array}{l}3.5 \\
2.8\end{array}$ \\
\hline EW3 & $\begin{array}{l}1.2 \\
1.5\end{array}$ & $\begin{array}{l}7.2 \\
6.6\end{array}$ & $\begin{array}{l}8.9 \\
7.5\end{array}$ & $\begin{array}{l}850 \\
980\end{array}$ & $\begin{array}{l}3.0 \\
2.3\end{array}$ & $\begin{array}{l}42 \\
39\end{array}$ & $\begin{array}{l}180 \\
200\end{array}$ & $\begin{array}{l}16 \\
17\end{array}$ & $\begin{array}{l}33 \\
26\end{array}$ & $\begin{array}{l}3.7 \\
3.2\end{array}$ \\
\hline
\end{tabular}


Table 5. Chemical analysis of drilling-core samples--Continued

\begin{tabular}{|c|c|c|c|c|c|c|c|c|c|c|}
\hline $\begin{array}{l}\text { Cluster } \\
\text { site }\end{array}$ & $\begin{array}{l}\text { Sample } \\
\text { depth } \\
\text { (m) }\end{array}$ & $\begin{array}{l}\text { Lanthanum } \\
\qquad(\mu \mathrm{g} / \mathrm{g})\end{array}$ & $\begin{array}{l}\text { Lead } \\
(\mu \mathrm{g} / \mathrm{g})\end{array}$ & $\begin{array}{l}\text { Lithium } \\
(\mu \mathrm{g} / \mathrm{g})\end{array}$ & $\begin{array}{l}\text { Magnesium } \\
\text { (percent) }\end{array}$ & $\begin{array}{c}\text { Manganese } \\
(\mu \mathrm{g} / \mathrm{g})\end{array}$ & $\begin{array}{l}\text { Molybdenum } \\
(\mu \mathrm{g} / \mathrm{g})\end{array}$ & $\begin{array}{l}\text { Neodymium } \\
(\mu \mathrm{g} / \mathrm{g})\end{array}$ & $\begin{array}{l}\text { Nickel } \\
(\mu \mathrm{g} / \mathrm{g})\end{array}$ & $\begin{array}{l}\text { Phos- } \\
\text { phorus } \\
(\mu \mathrm{g} / \mathrm{g})\end{array}$ \\
\hline \multirow[t]{11}{*}{ M10 } & 10.3 & 20 & 13 & 31 & 1.2 & 470 & $<2$ & 15 & 98 & 0.05 \\
\hline & 10.7 & 18 & 14 & 24 & 1.1 & 440 & $<2$ & 13 & 86 & .04 \\
\hline & 11.5 & 17 & 12 & 21 & 1.2 & 400 & $<2$ & 13 & 98 & .04 \\
\hline & 12.4 & 15 & 11 & 19 & 2.4 & 490 & $<2$ & 13 & 230 & .08 \\
\hline & 13.2 & 25 & 16 & 51 & 1.6 & 490 & $<2$ & 20 & 94 & .08 \\
\hline & 13.5 & 23 & 16 & 48 & 1.7 & 570 & $<2$ & 18 & 110 & .07 \\
\hline & 13.8 & 20 & 13 & 30 & 1.3 & 480 & $<2$ & 14 & 99 & .06 \\
\hline & 14.0 & 25 & 16 & 53 & 1.1 & 430 & $<2$ & 20 & 47 & .05 \\
\hline & 14.5 & 24 & 15 & 58 & 2.1 & 560 & $<2$ & 17 & 140 & .07 \\
\hline & 15.1 & 24 & 15 & 45 & 1.9 & 570 & $<2$ & 18 & 130 & .07 \\
\hline & 15.5 & 20 & 12 & 35 & 1.9 & 470 & $<2$ & 15 & 150 & .06 \\
\hline \multirow[t]{2}{*}{ NW1 } & 1.8 & 18 & 19 & 43 & 1.5 & 470 & $<2$ & 16 & 110 & .05 \\
\hline & 3.7 & 20 & 18 & 51 & 1.8 & 610 & $<2$ & 18 & 110 & .06 \\
\hline \multirow[t]{2}{*}{ NW4 } & 1.8 & 22 & 21 & 61 & 1.5 & 550 & $<2$ & 19 & 87 & .06 \\
\hline & 3.7 & 21 & 17 & 50 & 1.8 & 570 & $<2$ & 21 & 110 & .07 \\
\hline \multirow[t]{2}{*}{ NW7 } & 1.8 & 23 & 20 & 65 & 1.7 & 630 & $<2$ & 18 & 110 & .06 \\
\hline & 3.7 & 22 & 19 & 56 & 1.8 & 600 & $<2$ & 20 & 110 & .07 \\
\hline \multirow[t]{2}{*}{ NW10 } & 1.8 & 23 & 20 & 70 & 1.7 & 570 & $<2$ & 20 & 99 & .06 \\
\hline & 3.7 & 17 & 18 & 38 & 1.9 & 590 & $<2$ & 15 & 160 & .07 \\
\hline \multirow{2}{*}{ NW13 } & 1.8 & 21 & 19 & 51 & 1.6 & 500 & $<2$ & 17 & 93 & .06 \\
\hline & 3.7 & 17 & 17 & 40 & 1.8 & 500 & $<2$ & 15 & 130 & .06 \\
\hline \multirow[t]{2}{*}{$\mathrm{SE} 1$} & .9 & 21 & 19 & 52 & 1.5 & 540 & $<2$ & 18 & 91 & .06 \\
\hline & 1.5 & 19 & 18 & 46 & 1.7 & 530 & $<2$ & 18 & 100 & .06 \\
\hline \multirow[t]{2}{*}{ SE4 } & .9 & 20 & 19 & 52 & 1.3 & 550 & $<2$ & 17 & 81 & .06 \\
\hline & 1.5 & 19 & 18 & 45 & 2.0 & 600 & 2 & 16 & 150 & .06 \\
\hline \multirow[t]{2}{*}{ SE7 } & .9 & 21 & 20 & 52 & 1.4 & 520 & $<2$ & 17 & 83 & .06 \\
\hline & 1.5 & 22 & 18 & 62 & 1.8 & 560 & $<2$ & 20 & 110 & .07 \\
\hline \multirow[t]{2}{*}{ SE10 } & .9 & 21 & 21 & 55 & 1.4 & 540 & $<2$ & 18 & 83 & .06 \\
\hline & 1.5 & 22 & 20 & 63 & 1.9 & 600 & $<2$ & 21 & 110 & .07 \\
\hline \multirow[t]{2}{*}{ SE13 } & .9 & 19 & 17 & 40 & 1.0 & 470 & $<2$ & 15 & 65 & .06 \\
\hline & 1.5 & 19 & 17 & 48 & 1.6 & 550 & $<2$ & 18 & 100 & .06 \\
\hline \multirow{2}{*}{ EW2 } & 1.2 & 20 & 18 & 54 & 1.8 & 550 & $<2$ & 19 & 110 & .06 \\
\hline & 1.5 & 17 & 18 & 39 & 1.6 & 470 & $<2$ & 13 & 110 & .05 \\
\hline \multirow[t]{2}{*}{ EW3 } & 1.2 & 22 & 19 & 57 & 1.7 & 590 & $<2$ & 21 & 110 & .07 \\
\hline & 1.5 & 20 & 17 & 43 & 2.0 & 530 & $<2$ & 19 & 150 & .07 \\
\hline
\end{tabular}


Table 5. Chemical analysis of drilling-core samples--Continued

\begin{tabular}{|c|c|c|c|c|c|c|c|c|c|}
\hline $\begin{array}{l}\text { Cluster } \\
\text { site }\end{array}$ & $\begin{array}{l}\text { Sample } \\
\text { depth } \\
\text { (m) }\end{array}$ & $\begin{array}{l}\text { Potassium } \\
\text { (percent) }\end{array}$ & $\begin{array}{l}\text { Scandium } \\
(\mu \mathrm{g} / \mathrm{g})\end{array}$ & $\begin{array}{c}\text { Total } \\
\text { selenium } \\
(\mu \mathrm{g} / \mathrm{g})\end{array}$ & $\begin{array}{c}\text { Soluble } \\
\text { selenium } \\
(\mu \mathrm{g} / \mathrm{g})\end{array}$ & $\begin{array}{c}\text { Residual } \\
\text { selenium } \\
(\mu \mathrm{g} / \mathrm{g})\end{array}$ & $\begin{array}{l}\text { Silver } \\
(\mu \mathrm{g} / \mathrm{g})\end{array}$ & $\begin{array}{c}\text { Sodium } \\
\text { (percent) }\end{array}$ & $\begin{array}{l}\text { Strontium } \\
(\mu \mathrm{g} / \mathrm{g})\end{array}$ \\
\hline M10 & $\begin{array}{l}10.3 \\
10.7 \\
11.5 \\
12.4 \\
13.2 \\
13.5 \\
13.8 \\
14.0 \\
14.5 \\
15.1 \\
15.5\end{array}$ & $\begin{array}{l}2.0 \\
2.2 \\
2.2 \\
1.8 \\
2.1 \\
1.9 \\
2.2 \\
2.2 \\
1.8 \\
1.8 \\
1.9\end{array}$ & $\begin{array}{r}9 \\
7 \\
6 \\
7 \\
11 \\
12 \\
8 \\
11 \\
14 \\
11 \\
10\end{array}$ & $\begin{array}{r}0.6 \\
.5 \\
.4 \\
.6 \\
1.0 \\
1.0 \\
.9 \\
.8 \\
1.0 \\
1.0 \\
1.9\end{array}$ & $\begin{array}{c}0.11 \\
-. \\
.07 \\
.26 \\
.48 \\
.49 \\
.55 \\
.47 \\
.54 \\
.55 \\
.64\end{array}$ & $\begin{array}{r}0.49 \\
-- \\
.33 \\
.34 \\
.52 \\
.51 \\
.35 \\
.33 \\
.46 \\
.45 \\
1.26\end{array}$ & $\begin{array}{l}<2 \\
<2 \\
<2 \\
<2 \\
<2 \\
<2 \\
<2 \\
<2 \\
<2 \\
<2 \\
<2\end{array}$ & $\begin{array}{l}1.7 \\
1.6 \\
1.4 \\
1.3 \\
1.6 \\
1.7 \\
1.8 \\
1.7 \\
1.4 \\
1.8 \\
1.8\end{array}$ & $\begin{array}{l}240 \\
240 \\
210 \\
230 \\
270 \\
260 \\
270 \\
280 \\
270 \\
280 \\
290\end{array}$ \\
\hline NW1 & $\begin{array}{l}1.8 \\
3.7\end{array}$ & $\begin{array}{l}1.9 \\
1.9\end{array}$ & $\begin{array}{r}9 \\
11\end{array}$ & $\begin{array}{l}.8 \\
.9\end{array}$ & $\begin{array}{l}.03 \\
.02\end{array}$ & $\begin{array}{l}.77 \\
.88\end{array}$ & $\begin{array}{l}<2 \\
<2\end{array}$ & $\begin{array}{l}1.6 \\
1.7\end{array}$ & $\begin{array}{l}250 \\
260\end{array}$ \\
\hline NW4 & $\begin{array}{l}1.8 \\
3.7\end{array}$ & $\begin{array}{l}1.9 \\
1.8\end{array}$ & $\begin{array}{l}12 \\
11\end{array}$ & $\begin{array}{r}1.5 \\
.8\end{array}$ & $\begin{array}{l}.28 \\
.12\end{array}$ & $\begin{array}{r}1.22 \\
.68\end{array}$ & $\begin{array}{l}<2 \\
<2\end{array}$ & $\begin{array}{l}1.5 \\
1.7\end{array}$ & $\begin{array}{l}240 \\
260\end{array}$ \\
\hline NW7 & $\begin{array}{l}1.8 \\
3.7\end{array}$ & $\begin{array}{l}1.8 \\
1.8\end{array}$ & $\begin{array}{l}14 \\
12\end{array}$ & $\begin{array}{l}.9 \\
.7\end{array}$ & $\begin{array}{l}.02 \\
.00\end{array}$ & $\begin{array}{l}.88 \\
.70\end{array}$ & $\begin{array}{l}<2 \\
<2\end{array}$ & $\begin{array}{l}1.2 \\
1.5\end{array}$ & $\begin{array}{l}230 \\
260\end{array}$ \\
\hline NW10 & $\begin{array}{l}1.8 \\
3.7\end{array}$ & $\begin{array}{l}1.7 \\
2.0\end{array}$ & $\begin{array}{r}14 \\
9\end{array}$ & $\begin{array}{r}1.0 \\
.6\end{array}$ & $\begin{array}{l}.02 \\
.05\end{array}$ & $\begin{array}{l}.98 \\
.55\end{array}$ & $\begin{array}{l}<2 \\
<2\end{array}$ & $\begin{array}{l}1.1 \\
1.5\end{array}$ & $\begin{array}{l}240 \\
250\end{array}$ \\
\hline NW13 & $\begin{array}{l}1.8 \\
3.7\end{array}$ & $\begin{array}{l}2.0 \\
2.0\end{array}$ & $\begin{array}{r}11 \\
9\end{array}$ & $\begin{array}{l}.8 \\
.7\end{array}$ & $\begin{array}{l}.02 \\
.02\end{array}$ & $\begin{array}{l}.78 \\
.68\end{array}$ & $\begin{array}{l}<2 \\
<2\end{array}$ & $\begin{array}{l}1.3 \\
1.5\end{array}$ & $\begin{array}{l}240 \\
260\end{array}$ \\
\hline SE1 & $\begin{array}{r}.9 \\
1.5\end{array}$ & $\begin{array}{l}1.9 \\
1.9\end{array}$ & $\begin{array}{l}11 \\
10\end{array}$ & $\begin{array}{r}1.1 \\
.8\end{array}$ & $\begin{array}{l}.07 \\
.10\end{array}$ & $\begin{array}{r}1.03 \\
.70\end{array}$ & $\begin{array}{l}<2 \\
<2\end{array}$ & $\begin{array}{l}1.7 \\
1.8\end{array}$ & $\begin{array}{l}260 \\
270\end{array}$ \\
\hline SE4 & $\begin{array}{r}.9 \\
1.5\end{array}$ & $\begin{array}{l}1.9 \\
1.7\end{array}$ & $\begin{array}{l}10 \\
10\end{array}$ & $\begin{array}{l}1.4 \\
1.1\end{array}$ & $\begin{array}{l}.26 \\
.35\end{array}$ & $\begin{array}{r}1.14 \\
.75\end{array}$ & $\begin{array}{l}<2 \\
<2\end{array}$ & $\begin{array}{l}1.7 \\
1.8\end{array}$ & $\begin{array}{l}260 \\
280\end{array}$ \\
\hline SE7 & $\begin{array}{r}.9 \\
1.5\end{array}$ & $\begin{array}{l}2.0 \\
1.8\end{array}$ & $\begin{array}{l}11 \\
13\end{array}$ & $\begin{array}{l}1.7 \\
2.0\end{array}$ & $\begin{array}{l}.67 \\
.52\end{array}$ & $\begin{array}{l}1.03 \\
1.48\end{array}$ & $\begin{array}{l}<2 \\
<2\end{array}$ & $\begin{array}{l}1.8 \\
1.7\end{array}$ & $\begin{array}{l}240 \\
250\end{array}$ \\
\hline SE10 & $\begin{array}{r}.9 \\
1.5\end{array}$ & $\begin{array}{l}1.9 \\
1.8\end{array}$ & $\begin{array}{l}11 \\
13\end{array}$ & $\begin{array}{l}1.5 \\
2.0\end{array}$ & $\begin{array}{l}.25 \\
.87\end{array}$ & $\begin{array}{l}1.25 \\
1.13\end{array}$ & $\begin{array}{l}<2 \\
<2\end{array}$ & $\begin{array}{l}1.6 \\
1.5\end{array}$ & $\begin{array}{l}260 \\
290\end{array}$ \\
\hline SE13 & $\begin{array}{r}.9 \\
1.5\end{array}$ & $\begin{array}{l}2.0 \\
1.8\end{array}$ & $\begin{array}{r}8 \\
10\end{array}$ & $\begin{array}{r}.9 \\
1.3\end{array}$ & $\begin{array}{l}.02 \\
.38\end{array}$ & $\begin{array}{l}.88 \\
.92\end{array}$ & $\begin{array}{l}<2 \\
<2\end{array}$ & $\begin{array}{l}1.5 \\
1.5\end{array}$ & $\begin{array}{l}250 \\
260\end{array}$ \\
\hline EW2 & $\begin{array}{l}1.2 \\
1.5\end{array}$ & $\begin{array}{l}1.7 \\
2.1\end{array}$ & $\begin{array}{r}11 \\
8\end{array}$ & $\begin{array}{l}1.5 \\
1.5\end{array}$ & .26 & $\overline{1.24}$ & $\begin{array}{l}<2 \\
<2\end{array}$ & $\begin{array}{l}1.4 \\
1.6\end{array}$ & $\begin{array}{l}280 \\
250\end{array}$ \\
\hline EW3 & $\begin{array}{l}1.2 \\
1.5\end{array}$ & $\begin{array}{l}1.7 \\
1.8\end{array}$ & $\begin{array}{l}12 \\
10\end{array}$ & $\begin{array}{r}1.1 \\
.8\end{array}$ &.-.16 & .64 & $\begin{array}{l}<2 \\
<2\end{array}$ & $\begin{array}{l}1.5 \\
1.7\end{array}$ & $\begin{array}{l}260 \\
270\end{array}$ \\
\hline
\end{tabular}


Table 5. Chemical analysis of drilling-core samples--Continued

\begin{tabular}{|c|c|c|c|c|c|c|c|c|c|c|}
\hline $\begin{array}{l}\text { Cluster } \\
\text { site }\end{array}$ & $\begin{array}{c}\text { Sample } \\
\text { depth } \\
\text { (m) }\end{array}$ & $\begin{array}{c}\text { Thorium } \\
(\mu \mathrm{g} / \mathrm{g})\end{array}$ & $\begin{array}{c}\text { Titanium } \\
(\mu \mathrm{g} / \mathrm{g})\end{array}$ & $\begin{array}{c}\text { Tin } \\
\text { (percent) }\end{array}$ & $\begin{array}{c}\text { Vanadium } \\
(\mu \mathrm{g} / \mathrm{g})\end{array}$ & $\begin{array}{c}\text { Yttrium } \\
(\mu \mathrm{g} / \mathrm{g})\end{array}$ & $\begin{array}{l}\text { Zinc } \\
(\mu \mathrm{g} / \mathrm{g})\end{array}$ & $\begin{array}{c}\text { Total } \\
\text { carbon } \\
\text { (percent) }\end{array}$ & $\begin{array}{c}\text { Organic } \\
\text { carbon } \\
\text { (percent) }\end{array}$ & $\begin{array}{c}\text { Carbonate } \\
\text { (percent) }\end{array}$ \\
\hline M10 & $\begin{array}{l}10.3 \\
10.7 \\
11.5 \\
12.4 \\
13.2 \\
13.5 \\
13.8 \\
14.0 \\
14.5 \\
15.1 \\
15.5\end{array}$ & $\begin{array}{r}6 \\
5 \\
7 \\
7 \\
9 \\
10 \\
7 \\
12 \\
9 \\
9 \\
8\end{array}$ & $\begin{array}{r}0.24 \\
.22 \\
.19 \\
.17 \\
.30 \\
.32 \\
.23 \\
.30 \\
.34 \\
.33 \\
.26\end{array}$ & $\begin{array}{l}<10 \\
<10 \\
<10 \\
<10 \\
<10 \\
<10 \\
<10 \\
<10 \\
<10 \\
<10 \\
<10\end{array}$ & $\begin{array}{r}66 \\
54 \\
48 \\
51 \\
92 \\
96 \\
62 \\
87 \\
110 \\
93 \\
74\end{array}$ & $\begin{array}{l}12 \\
11 \\
10 \\
11 \\
19 \\
16 \\
12 \\
15 \\
16 \\
16 \\
13\end{array}$ & $\begin{array}{l}57 \\
47 \\
38 \\
38 \\
83 \\
84 \\
55 \\
78 \\
93 \\
76 \\
58\end{array}$ & $\begin{array}{r}0.34 \\
.25 \\
.26 \\
.46 \\
.29 \\
.39 \\
.25 \\
.19 \\
.56 \\
.46 \\
.39\end{array}$ & $\begin{array}{r}0.03 \\
.02 \\
.05 \\
.01 \\
.05 \\
.09 \\
.02 \\
.04 \\
.08 \\
.06 \\
.07\end{array}$ & $\begin{array}{r}0.31 \\
.23 \\
.21 \\
.46 \\
.24 \\
.30 \\
.23 \\
.15 \\
.48 \\
.40 \\
.32\end{array}$ \\
\hline NW1 & $\begin{array}{l}1.8 \\
3.7\end{array}$ & $\begin{array}{l}8 \\
9\end{array}$ & $\begin{array}{l}.26 \\
.31\end{array}$ & $\begin{array}{l}<20 \\
<20\end{array}$ & $\begin{array}{r}86 \\
100\end{array}$ & $\begin{array}{l}12 \\
15\end{array}$ & $\begin{array}{l}73 \\
88\end{array}$ & $\begin{array}{l}.63 \\
.46\end{array}$ & $\begin{array}{l}.16 \\
.14\end{array}$ & $\begin{array}{l}.47 \\
.32\end{array}$ \\
\hline NW4 & $\begin{array}{l}1.8 \\
3.7\end{array}$ & $\begin{array}{r}11 \\
9\end{array}$ & $\begin{array}{l}.32 \\
.33\end{array}$ & $\begin{array}{l}<20 \\
<20\end{array}$ & $\begin{array}{l}120 \\
100\end{array}$ & $\begin{array}{l}15 \\
15\end{array}$ & $\begin{array}{r}100 \\
86\end{array}$ & $\begin{array}{l}.55 \\
.43\end{array}$ & $\begin{array}{l}.26 \\
.09\end{array}$ & $\begin{array}{l}.29 \\
.34\end{array}$ \\
\hline NW7 & $\begin{array}{l}1.8 \\
3.7\end{array}$ & $\begin{array}{r}11 \\
9\end{array}$ & $\begin{array}{l}.33 \\
.35\end{array}$ & $\begin{array}{l}<20 \\
<20\end{array}$ & $\begin{array}{l}130 \\
110\end{array}$ & $\begin{array}{l}15 \\
16\end{array}$ & $\begin{array}{r}110 \\
94\end{array}$ & $\begin{array}{l}.50 \\
.48\end{array}$ & $\begin{array}{l}.22 \\
.11\end{array}$ & $\begin{array}{l}.28 \\
.37\end{array}$ \\
\hline NW10 & $\begin{array}{l}1.8 \\
3.7\end{array}$ & $\begin{array}{r}11 \\
7\end{array}$ & $\begin{array}{l}.36 \\
.26\end{array}$ & $\begin{array}{l}<20 \\
<20\end{array}$ & $\begin{array}{r}140 \\
81\end{array}$ & $\begin{array}{l}16 \\
12\end{array}$ & $\begin{array}{r}110 \\
67\end{array}$ & $\begin{array}{l}.53 \\
.30\end{array}$ & $\begin{array}{l}.23 \\
.06\end{array}$ & $\begin{array}{l}.30 \\
.24\end{array}$ \\
\hline NW13 & $\begin{array}{l}1.8 \\
3.7\end{array}$ & $\begin{array}{l}9 \\
8\end{array}$ & $\begin{array}{l}.29 \\
.26\end{array}$ & $\begin{array}{l}<20 \\
<20\end{array}$ & $\begin{array}{r}100 \\
82\end{array}$ & $\begin{array}{l}13 \\
12\end{array}$ & $\begin{array}{l}92 \\
69\end{array}$ & $\begin{array}{l}.39 \\
.42\end{array}$ & $\begin{array}{l}.16 \\
.10\end{array}$ & $\begin{array}{l}.23 \\
.32\end{array}$ \\
\hline SE1 & $\begin{array}{r}.9 \\
1.5\end{array}$ & $\begin{array}{l}9 \\
8\end{array}$ & $\begin{array}{l}.31 \\
.30\end{array}$ & $\begin{array}{l}<20 \\
<20\end{array}$ & $\begin{array}{r}100 \\
90\end{array}$ & $\begin{array}{l}14 \\
14\end{array}$ & $\begin{array}{l}89 \\
77\end{array}$ & $\begin{array}{l}.48 \\
.35\end{array}$ & $\begin{array}{l}.18 \\
.09\end{array}$ & $\begin{array}{l}.30 \\
.26\end{array}$ \\
\hline SE4 & $\begin{array}{r}.9 \\
1.5\end{array}$ & $\begin{array}{l}9 \\
7\end{array}$ & $\begin{array}{l}.31 \\
.30\end{array}$ & $\begin{array}{l}<20 \\
<20\end{array}$ & $\begin{array}{r}100 \\
92\end{array}$ & $\begin{array}{l}14 \\
14\end{array}$ & $\begin{array}{l}90 \\
78\end{array}$ & $\begin{array}{l}.46 \\
.48\end{array}$ & $\begin{array}{l}.19 \\
.14\end{array}$ & $\begin{array}{l}.27 \\
.34\end{array}$ \\
\hline SE7 & $\begin{array}{r}.9 \\
1.5\end{array}$ & $\begin{array}{r}9 \\
10\end{array}$ & $\begin{array}{l}.30 \\
.35\end{array}$ & $\begin{array}{l}<20 \\
<20\end{array}$ & $\begin{array}{l}100 \\
120\end{array}$ & $\begin{array}{l}14 \\
.15\end{array}$ & $\begin{array}{r}90 \\
100\end{array}$ & $\begin{array}{l}.43 \\
.54\end{array}$ & $\begin{array}{l}.20 \\
.18\end{array}$ & $\begin{array}{l}.23 \\
.36\end{array}$ \\
\hline SE10 & $\begin{array}{r}.9 \\
1.5\end{array}$ & $\begin{array}{l}10 \\
12\end{array}$ & $\begin{array}{l}.31 \\
.35\end{array}$ & $\begin{array}{l}<20 \\
<20\end{array}$ & $\begin{array}{l}110 \\
120\end{array}$ & $\begin{array}{l}14 \\
16\end{array}$ & $\begin{array}{r}95 \\
100\end{array}$ & $\begin{array}{l}.46 \\
.59\end{array}$ & $\begin{array}{l}.20 \\
.17\end{array}$ & $\begin{array}{l}.26 \\
.42\end{array}$ \\
\hline SE13 & $\begin{array}{r}.9 \\
1.5\end{array}$ & $\begin{array}{l}8 \\
9\end{array}$ & $\begin{array}{l}.28 \\
.29\end{array}$ & $\begin{array}{l}<20 \\
<20\end{array}$ & $\begin{array}{l}82 \\
96\end{array}$ & $\begin{array}{l}13 \\
14\end{array}$ & $\begin{array}{l}73 \\
81\end{array}$ & $\begin{array}{l}.41 \\
.49\end{array}$ & $\begin{array}{l}.15 \\
.13\end{array}$ & $\begin{array}{l}.26 \\
.36\end{array}$ \\
\hline EW2 & $\begin{array}{l}1.2 \\
1.5\end{array}$ & $\begin{array}{l}8 \\
8\end{array}$ & $\begin{array}{l}.31 \\
.25\end{array}$ & $\begin{array}{l}<20 \\
<20\end{array}$ & $\begin{array}{r}100 \\
78\end{array}$ & $\begin{array}{l}14 \\
12\end{array}$ & $\begin{array}{l}86 \\
68\end{array}$ & $\begin{array}{l}.83 \\
.40\end{array}$ & $\begin{array}{l}.16 \\
.11\end{array}$ & $\begin{array}{l}.67 \\
.29\end{array}$ \\
\hline EW3 & $\begin{array}{l}1.2 \\
1.5\end{array}$ & $\begin{array}{l}8 \\
9\end{array}$ & $\begin{array}{l}.35 \\
.31\end{array}$ & $\begin{array}{l}<20 \\
<20\end{array}$ & $\begin{array}{r}110 \\
92\end{array}$ & $\begin{array}{l}15 \\
14\end{array}$ & $\begin{array}{l}95 \\
74\end{array}$ & $\begin{array}{l}.52 \\
.43\end{array}$ & $\begin{array}{l}.16 \\
.13\end{array}$ & $\begin{array}{l}.36 \\
.30\end{array}$ \\
\hline
\end{tabular}


Table 6. Selenium, dissolved solids, and stable isotope data for welis with multiple samples

[Cluster site: Site at which one to five observation wells were completed at different depths. Well depth: Depth, in meters below land surface, of each observation well completed at cluster site. --, no data; $\mu \mathrm{g} / \mathrm{L}$, microgram per liter; $\mathrm{mg} / \mathrm{L}$, milligram per liter]

\begin{tabular}{|c|c|c|c|c|c|c|}
\hline Cluster site & Well depth & Date & $\begin{array}{c}\text { Selenium, } \\
\text { dissolved } \\
(\mu \mathrm{g} / \mathrm{L})\end{array}$ & $\begin{array}{l}\text { Solids, sum of } \\
\text { constituents, } \\
\text { dissolved } \\
(\mathrm{mg} / \mathrm{L})\end{array}$ & $\begin{array}{c}{ }^{2} \mathrm{H} /{ }^{1} \mathrm{H} \text { stable- } \\
\text { isotope ratio } \\
\text { (per mil) }\end{array}$ & $\begin{array}{c}{ }^{18} \mathrm{O} /{ }^{16} \mathrm{O} \text { stable- } \\
\text { isotope ratio } \\
\text { (per mil) }\end{array}$ \\
\hline EW1 & 4 & $\begin{array}{l}2-04-86 \\
7-17-86 \\
7-30-86\end{array}$ & $\begin{array}{r}1,000 \\
510 \\
390\end{array}$ & $\begin{array}{r}-. \\
7,690 \\
8,420\end{array}$ & $\begin{array}{c}-58.5 \\
-- \\
--\end{array}$ & $\begin{array}{l}-6.85 \\
-- \\
--\end{array}$ \\
\hline EW4 & 4 & $\begin{array}{l}7-17-86 \\
7-30-86\end{array}$ & $\begin{array}{l}2,200 \\
2,000\end{array}$ & $\begin{array}{l}18,000 \\
13,600\end{array}$ & $\begin{array}{l}-- \\
--\end{array}$ & $\begin{array}{l}-- \\
--\end{array}$ \\
\hline EW5 & 4 & $\begin{array}{l}7-17-86 \\
7-30-86\end{array}$ & $\begin{array}{l}1,900 \\
1,800\end{array}$ & $\begin{array}{l}16,600 \\
15,700\end{array}$ & $\begin{array}{l}-- \\
--\end{array}$ & $\begin{array}{l}-- \\
--\end{array}$ \\
\hline EW6 & 4 & $\begin{array}{l}7-17-86 \\
7-30-86\end{array}$ & $\begin{array}{l}19 \\
39\end{array}$ & $\begin{array}{l}5,400 \\
6,150\end{array}$ & $\begin{array}{l}-- \\
--\end{array}$ & $\begin{array}{l}-. \\
--\end{array}$ \\
\hline MBS & 9 & $\begin{array}{l}4-01-87 \\
9-01-88\end{array}$ & $\begin{array}{l}3,900 \\
4,600\end{array}$ & $\begin{array}{l}17,000 \\
19,100\end{array}$ & $\begin{array}{l}-56.0 \\
-55.0\end{array}$ & $\begin{array}{l}-5.55 \\
-5.00\end{array}$ \\
\hline M1 & $\begin{array}{l}3 \\
6\end{array}$ & $\begin{array}{l}6-11-87 \\
7-20-88 \\
6-11-87 \\
7-20-88\end{array}$ & $\begin{array}{r}310 \\
27 \\
11 \\
25\end{array}$ & $\begin{array}{l}8,950 \\
8,210 \\
8,240 \\
8,390\end{array}$ & $\begin{array}{l}-67.5 \\
-66.0 \\
-63.0 \\
-67.0\end{array}$ & $\begin{array}{l}-8.75 \\
-8.65 \\
-8.25 \\
-8.25\end{array}$ \\
\hline M4 & $\begin{array}{r}6 \\
9 \\
15\end{array}$ & $\begin{array}{l}6-10-87 \\
7-22-88 \\
6-10-87 \\
7-20-88 \\
6-10-87 \\
7-20-88\end{array}$ & $\begin{array}{r}4,100 \\
3,100 \\
190 \\
970 \\
330 \\
340\end{array}$ & $\begin{array}{r}18,200 \\
19,600 \\
13,100 \\
15,700 \\
9,810 \\
10,700\end{array}$ & $\begin{array}{c}-56.5 \\
-57.5 \\
-- \\
-61.5 \\
-61.0 \\
-62.5\end{array}$ & $\begin{array}{l}-6.25 \\
-6.40 \\
-- \\
-7.35 \\
-7.45 \\
-7.55\end{array}$ \\
\hline M5 & $\begin{array}{r}6 \\
9 \\
12 \\
15\end{array}$ & $\begin{array}{l}6-09-87 \\
7-21-88 \\
6-09-87 \\
7-21-88 \\
7-01-87 \\
7-21-88 \\
6-09-87 \\
7-21-88\end{array}$ & $\begin{array}{l}820 \\
500 \\
520 \\
240 \\
200 \\
170 \\
200 \\
110\end{array}$ & $\begin{array}{r}9,450 \\
8,220 \\
12,000 \\
13,100 \\
4,020 \\
6,420 \\
12,200 \\
9,400\end{array}$ & $\begin{array}{l}-59.5 \\
-62.0 \\
-63.0 \\
-62.5 \\
-61.5 \\
-64.0 \\
-61.0 \\
-63.0\end{array}$ & $\begin{array}{l}-7.50 \\
-7.50 \\
-7.85 \\
-7.70 \\
-8.10 \\
-8.10 \\
-7.55 \\
-8.05\end{array}$ \\
\hline NW10 & 3 & $\begin{array}{l}1-31-86 \\
7-22-88\end{array}$ & $\begin{array}{l}370 \\
160\end{array}$ & $\begin{array}{r}13,700 \\
6,340\end{array}$ & $\begin{array}{l}-60.0 \\
-66.5\end{array}$ & $\begin{array}{l}-7.15 \\
-8.60\end{array}$ \\
\hline SE1 & 4 & $\begin{array}{l}2-05-86 \\
5-23-86 \\
7-16-86 \\
7-29-86\end{array}$ & $\begin{array}{l}330 \\
320 \\
290 \\
370\end{array}$ & $\begin{array}{l}12,300 \\
12,800 \\
12,600 \\
12,400\end{array}$ & $\begin{array}{c}-56.0 \\
-- \\
-- \\
.-\end{array}$ & $\begin{array}{l}-5.55 \\
-- \\
-- \\
--\end{array}$ \\
\hline SE4 & 4 & $\begin{array}{l}2-05-86 \\
5-22-86 \\
7-15-86 \\
7-29-86\end{array}$ & $\begin{array}{r}1,300 \\
540 \\
1,000 \\
1,100\end{array}$ & $\begin{array}{r}10,400 \\
9,250 \\
9,960 \\
11,600\end{array}$ & $\begin{array}{c}-57.0 \\
-- \\
-- \\
--\end{array}$ & $\begin{array}{l}-5.85 \\
-- \\
-- \\
--\end{array}$ \\
\hline
\end{tabular}


Table 6. Selenium, dissolved solids, and stable isotope data for wells with multiple samples--Continued

\begin{tabular}{|c|c|c|c|c|c|c|}
\hline Cluster site & Well depth & Date & $\begin{array}{l}\text { Selenium, } \\
\text { dissolved } \\
(\mu \mathrm{g} / \mathrm{L})\end{array}$ & $\begin{array}{l}\text { Solids, sum of } \\
\text { constituents, } \\
\text { dissolved } \\
(\mathrm{mg} / \mathrm{L})\end{array}$ & $\begin{array}{c}{ }^{2} \mathrm{H} /{ }^{\mathrm{H}} \mathrm{H} \text { stable- } \\
\text { isotope ratio } \\
\text { (per mil) }\end{array}$ & $\begin{array}{c}{ }^{18} \mathrm{O} /{ }^{16} \mathrm{O} \text { stable } \\
\text { isotope ratio } \\
\text { (per mil) }\end{array}$ \\
\hline SE7 & 4 & $\begin{array}{l}2-05-86 \\
5-21-86 \\
7-16-86 \\
7-29-86\end{array}$ & $\begin{array}{l}4,400 \\
3,900 \\
4,400 \\
4,100\end{array}$ & $\begin{array}{l}21,000 \\
21,200 \\
18,100 \\
20,500\end{array}$ & $\begin{array}{c}-56.5 \\
-- \\
-- \\
--\end{array}$ & $\begin{array}{l}-5.70 \\
-- \\
-- \\
--\end{array}$ \\
\hline SE10 & 4 & $\begin{array}{l}2-05-86 \\
5-21-86 \\
7-31-86 \\
9-01-88\end{array}$ & $\begin{array}{r}3,000 \\
630 \\
620 \\
990\end{array}$ & $\begin{array}{l}14,200 \\
11,400 \\
10,700 \\
12,900\end{array}$ & $\begin{array}{c}-58.5 \\
-- \\
-- \\
-61.5\end{array}$ & $\begin{array}{l}-6.15 \\
-- \\
-- \\
-7.00\end{array}$ \\
\hline SE13 & 4 & $\begin{array}{l}2-05-86 \\
5-21-86\end{array}$ & $\begin{array}{l}2,000 \\
2,600\end{array}$ & $\begin{array}{l}11,900 \\
11,800\end{array}$ & $\begin{array}{c}-62.5 \\
--\end{array}$ & $\begin{array}{l}-6.15 \\
--\end{array}$ \\
\hline 1 & 3 & $\begin{array}{l}7-30-86 \\
8-12-86 \\
8-30-88 \\
3-05-86 \\
8-30-88\end{array}$ & $\begin{array}{r}1,100 \\
1,100 \\
480 \\
2,200 \\
1,200\end{array}$ & $\begin{array}{r}11,400 \\
10,800 \\
9,390 \\
-- \\
14,600\end{array}$ & $\begin{array}{l}-- \\
-- \\
-65.0 \\
-54.0 \\
-55.0\end{array}$ & $\begin{array}{l}-- \\
-- \\
-7.70 \\
-4.75 \\
-5.20\end{array}$ \\
\hline 2 & $\begin{array}{r}3 \\
12\end{array}$ & $\begin{array}{l}5-23-86 \\
7-30-86 \\
9-01-88 \\
2-28-86 \\
9-01-88\end{array}$ & $\begin{array}{l}430 \\
690 \\
970 \\
800 \\
700\end{array}$ & $\begin{array}{r}14,900 \\
14,300 \\
12,500 \\
6,250 \\
6,170\end{array}$ & $\begin{array}{c}-- \\
-- \\
-56.0 \\
-58.0 \\
-59.5\end{array}$ & $\begin{array}{l}-- \\
-- \\
-5.80 \\
-6.70 \\
-6.85\end{array}$ \\
\hline 3 & 3 & $\begin{array}{l}7-31-86 \\
8-12-86\end{array}$ & $\begin{array}{l}280 \\
320\end{array}$ & $\begin{array}{r}7,840 \\
10,100\end{array}$ & -- & 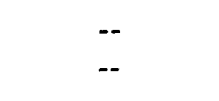 \\
\hline 4 & 12 & $\begin{array}{l}1-30-86 \\
5-22-86 \\
7-16-86 \\
7-29-86 \\
8-12-86 \\
2-06-86 \\
7-16-86 \\
7-29-86 \\
2-06-86 \\
7-16-86 \\
7-29-86\end{array}$ & $\begin{array}{r}-- \\
860 \\
950 \\
960 \\
1,000 \\
3,000 \\
2,900 \\
2,400 \\
1,100 \\
860 \\
1,100\end{array}$ & $\begin{array}{r}11,400 \\
11,300 \\
10,300 \\
13,300 \\
14,600 \\
15,200 \\
13,100 \\
8,160 \\
7,620 \\
8,580\end{array}$ & $\begin{array}{c}-62.5 \\
-- \\
-- \\
-- \\
- \\
-53.5 \\
-- \\
-- \\
-58.0 \\
-- \\
--\end{array}$ & $\begin{array}{l}-7.25 \\
-- \\
-- \\
-- \\
-- \\
-6.50 \\
-- \\
-- \\
-6.50 \\
-- \\
--\end{array}$ \\
\hline 7 & 3 & $\begin{array}{l}5-22-86 \\
7-15-86 \\
7-28-86 \\
8-12-86 \\
8-30-88 \\
3-06-86 \\
7-15-86 \\
7-29-86 \\
8-30-88\end{array}$ & $\begin{array}{r}890 \\
1,100 \\
970 \\
960 \\
1,100 \\
2,500 \\
2,500 \\
2,300 \\
1,700\end{array}$ & $\begin{array}{r}10,500 \\
10,500 \\
9,420 \\
10,500 \\
10,600 \\
12,900 \\
13,400 \\
11,900 \\
13,900\end{array}$ & $\begin{array}{c}-- \\
-- \\
-- \\
-- \\
-59.5 \\
-55.5 \\
-- \\
-- \\
-55.5\end{array}$ & $\begin{array}{l}-- \\
-- \\
-- \\
-6.65 \\
-5.15 \\
-- \\
-- \\
-5.30\end{array}$ \\
\hline
\end{tabular}


Table 6. Selenium, dissolved solids, and stable isotope data for wells with multiple samples--Continued

\begin{tabular}{|c|c|c|c|c|c|c|}
\hline Cluster site & Well depth & Date & $\begin{array}{l}\text { Selenium, } \\
\text { dissolved } \\
(\mu \mathrm{g} / \mathrm{L})\end{array}$ & $\begin{array}{l}\text { Solids, sum of } \\
\text { constituents, } \\
\text { dissolved } \\
(\mathrm{mg} / \mathrm{L})\end{array}$ & $\begin{array}{c}{ }^{2} \mathrm{H} /{ }^{1} \mathrm{H} \text { stable- } \\
\text { isotope ratio } \\
\text { (per mil) }\end{array}$ & $\begin{array}{c}{ }^{18} \mathrm{O} /{ }^{16} \mathrm{O} \text { stable- } \\
\text { isotope ratio } \\
\text { (per mil) }\end{array}$ \\
\hline 7 & 12 & $\begin{array}{l}2-11-86 \\
7-15-86 \\
7-29-86 \\
8-30-88 \\
2-11-86 \\
7-15-86 \\
7-28-86 \\
8-30-88\end{array}$ & $\begin{array}{l}5,500 \\
4,400 \\
4,400 \\
4,000 \\
1,500 \\
1,200 \\
1,000 \\
1,900\end{array}$ & $\begin{array}{r}20,400 \\
19,700 \\
16,400 \\
18,800 \\
9,560 \\
9,210 \\
9,710 \\
12,100\end{array}$ & $\begin{array}{c}-53.0 \\
-- \\
- \\
-52.5 \\
-58.5 \\
-- \\
-- \\
-57.0\end{array}$ & $\begin{array}{l}-4.45 \\
-- \\
- \\
-4.70 \\
-6.45 \\
-- \\
-- \\
-5.85\end{array}$ \\
\hline 9 & $\begin{array}{r}6 \\
9 \\
12\end{array}$ & $\begin{array}{l}7-15-86 \\
7-28-86 \\
8-13-86 \\
3-06-86 \\
7-16-86 \\
7-28-86 \\
2-11-86 \\
7-16-86 \\
7-28-86 \\
2-28-86 \\
7-15-86 \\
7-29-86\end{array}$ & $\begin{array}{r}910 \\
1,200 \\
1,500 \\
2,500 \\
2,400 \\
2,200 \\
5,600 \\
4,500 \\
4,300 \\
1,700 \\
1,500 \\
1,500\end{array}$ & $\begin{array}{l}10,600 \\
11,600 \\
10,700 \\
12,000 \\
12,700 \\
11,800 \\
19,000 \\
19,200 \\
18,700 \\
11,700 \\
12,400 \\
15,400\end{array}$ & $\begin{array}{c}-- \\
-- \\
-- \\
-54.5 \\
-- \\
-- \\
-53.5 \\
-- \\
-- \\
-58.5 \\
-- \\
--\end{array}$ & $\begin{array}{l}-- \\
-- \\
-- \\
-4.80 \\
-- \\
-- \\
-4.50 \\
-- \\
-- \\
-6.55 \\
-- \\
--\end{array}$ \\
\hline 10 & 9 & $\begin{array}{l}2-25-86 \\
2-26-86\end{array}$ & $\begin{array}{l}4,900 \\
5,200\end{array}$ & $\begin{array}{l}18,900 \\
18,600\end{array}$ & $\begin{array}{c}-55.5 \\
--\end{array}$ & $\begin{array}{l}-4.80 \\
--\end{array}$ \\
\hline 12 & 9 & $\begin{array}{l}7-16-86 \\
7-29-86 \\
8-13-86 \\
7-17-86 \\
7-31-86\end{array}$ & $\begin{array}{r}980 \\
900 \\
1,000 \\
2,100 \\
2,400\end{array}$ & $\begin{array}{l}15,700 \\
13,700 \\
15,700 \\
12,900 \\
16,300\end{array}$ & $\begin{array}{l}-- \\
-- \\
-- \\
-- \\
--\end{array}$ & $\begin{array}{l}-- \\
- \\
- \\
-- \\
--\end{array}$ \\
\hline 13 & $\begin{array}{r}6 \\
12\end{array}$ & $\begin{array}{l}3-06-86 \\
4-02-87 \\
2-27-86 \\
4-02-87\end{array}$ & $\begin{array}{r}2,400 \\
1,100 \\
790 \\
870\end{array}$ & $\begin{array}{r}14,900 \\
10,100 \\
7,830 \\
7,760\end{array}$ & $\begin{array}{l}-56.0 \\
-60.0 \\
-59.5 \\
-60.0\end{array}$ & $\begin{array}{l}-5.45 \\
-6.85 \\
-6.95 \\
-7.30\end{array}$ \\
\hline 14 & $\begin{array}{l}3 \\
6 \\
8\end{array}$ & $\begin{array}{l}7-30-86 \\
8-14-86 \\
3-06-86 \\
4-02-87 \\
2-27-86 \\
4-02-87\end{array}$ & $\begin{array}{l}2,700 \\
2,900 \\
8,200 \\
6,000 \\
9,500 \\
7,300\end{array}$ & $\begin{array}{l}17,400 \\
18,600 \\
22,900 \\
24,900 \\
27,800 \\
26,900\end{array}$ & $\begin{array}{c}-- \\
-- \\
-54.0 \\
-55.0 \\
-51.0 \\
-52.5\end{array}$ & $\begin{array}{l}-- \\
-- \\
-4.45 \\
-4.65 \\
-3.40 \\
-4.05\end{array}$ \\
\hline 15 & $\begin{array}{r}6 \\
12\end{array}$ & $\begin{array}{l}3-06-86 \\
8-31-88 \\
2-27-86 \\
8-31-88\end{array}$ & $\begin{array}{r}4,200 \\
3,300 \\
990 \\
960\end{array}$ & $\begin{array}{r}16,700 \\
18,100 \\
6,910 \\
7,270\end{array}$ & $\begin{array}{l}-56.0 \\
-57.5 \\
-60.0 \\
-61.0\end{array}$ & $\begin{array}{l}-5.70 \\
-5.70 \\
-6.85 \\
-6.90\end{array}$ \\
\hline
\end{tabular}


Table 7. Field measurements and chemical analysis of drainwater

$\left[\mu \mathrm{S} / \mathrm{cm}\right.$, microsiemen per centimeter at $25{ }^{\circ} \mathrm{C}$; ${ }^{\circ} \mathrm{C}$, degree Celsius; $\mathrm{mg} / \mathrm{L}$, milligram per liter; $\mathrm{TU}$, tritium unit. --, no data; $<$, actual value is less than value shown]

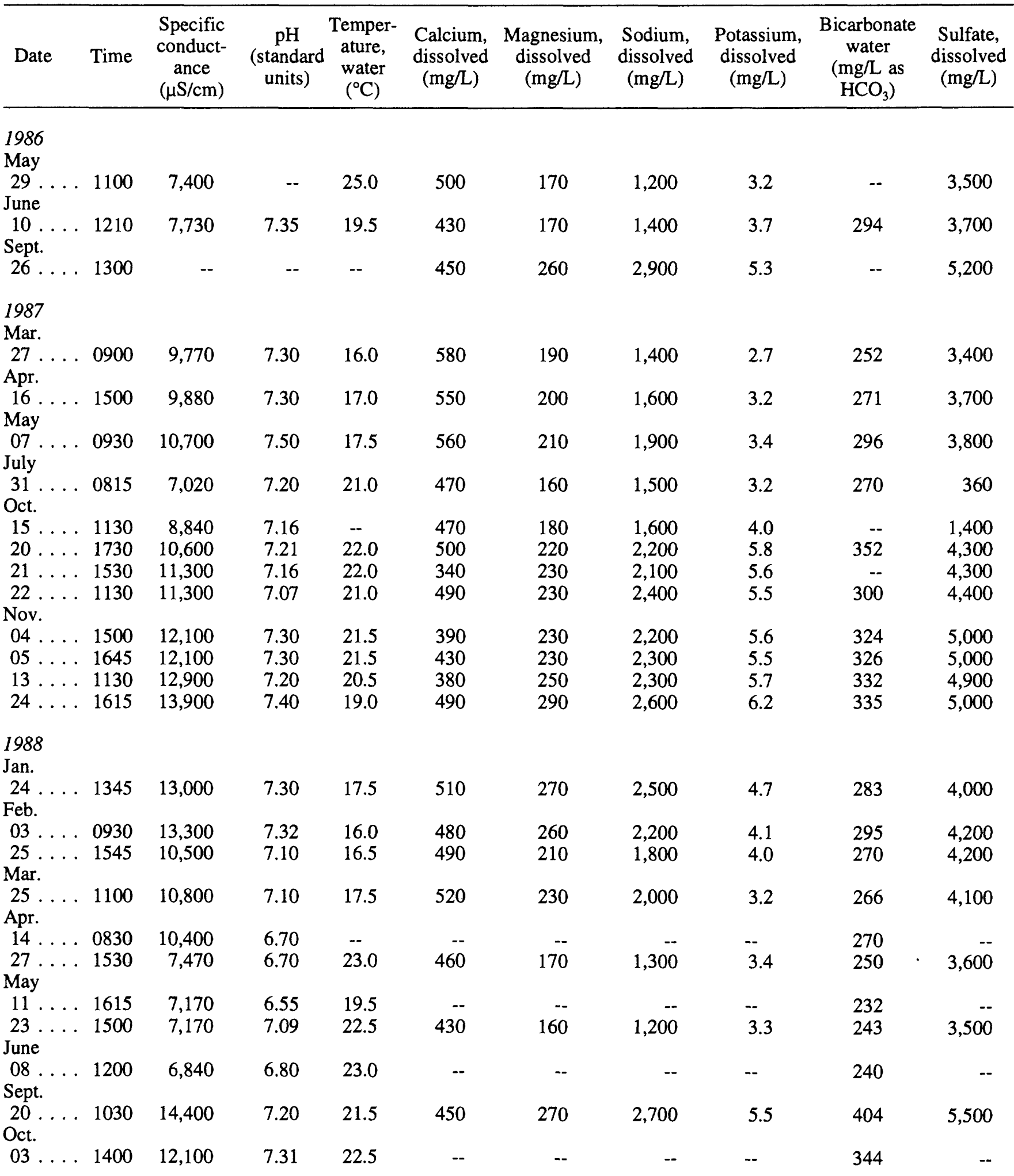


Table 7. Field measurements and chemical analysis of drainwater--Continued

\begin{tabular}{|c|c|c|c|c|c|c|c|c|c|c|}
\hline Date & $\begin{array}{c}\text { Chloride, } \\
\text { dissolved } \\
(\mathrm{mg} / \mathrm{L})\end{array}$ & $\begin{array}{c}\text { Silica, } \\
\text { dissolved } \\
(\mathrm{mg} / \mathrm{L})\end{array}$ & $\begin{array}{l}\text { Solids, } \\
\text { sum of } \\
\text { consti- } \\
\text { tuents, } \\
\text { dissolved } \\
(\mathrm{mg} / \mathrm{L})\end{array}$ & $\begin{array}{c}\text { Nitrogen, } \\
\text { nitrate, } \\
\text { dissolved } \\
(\mathrm{mg} / \mathrm{L} \\
\text { as } \mathrm{N})\end{array}$ & $\begin{array}{l}\text { Nitrogen, } \\
\text { nitrate } \\
\text { plus } \\
\text { nitrite, } \\
\text { dissolved } \\
\text { (mg/L } \\
\text { as } \mathrm{N} \text { ) }\end{array}$ & $\begin{array}{l}\text { Aluminum, } \\
\text { dissolved } \\
(\mathrm{mg} / \mathrm{L})\end{array}$ & $\begin{array}{l}\text { Boron, } \\
\text { dissolved } \\
(\mathrm{mg} / \mathrm{L})\end{array}$ & $\begin{array}{c}\text { Chromium, } \\
\text { dissolved } \\
(\mathrm{mg} / \mathrm{L})\end{array}$ & $\begin{array}{c}\text { Iron, } \\
\text { dissolved } \\
\text { (mg/L) }\end{array}$ & $\begin{array}{l}\text { Lithium, } \\
\text { dissolved } \\
(\mathrm{mg} / \mathrm{L})\end{array}$ \\
\hline \multicolumn{11}{|l|}{$\begin{array}{l}1986 \\
\text { May }\end{array}$} \\
\hline $\begin{array}{l}29 \\
\text { June }\end{array}$ & 580 & 52 & 6,020 & -- & - & $<10$ & 9,500 & 10 & 60 & 250 \\
\hline $\begin{array}{l}10 \ldots \\
\text { Sept. }\end{array}$ & -- & 51 & -- & -- & -- & 20 & 9,900 & 10 & 90 & -- \\
\hline $26 \ldots$ & 2,000 & 55 & 10,900 & -- & -- & $<10$ & 21,000 & 10 & 60 & 360 \\
\hline $\begin{array}{l}1987 \\
\text { Mar. }\end{array}$ & & & & & & & & & & \\
\hline $\begin{array}{l}27 . \\
\text { Apr. }\end{array}$ & 1,300 & 55 & 7,460 & 0.030 & 91.0 & $<10$ & 9,700 & 5 & 60 & 240 \\
\hline $\begin{array}{l}16 . . \\
\text { May }\end{array}$ & 1,400 & 54 & 8,060 & .010 & 92.0 & $<10$ & 11,000 & 5 & 60 & 250 \\
\hline $\begin{array}{c}07 \\
\text { July }\end{array}$ & 1,200 & 52 & 8,320 & .250 & 100 & 10 & 14,000 & 7 & 50 & 360 \\
\hline $\begin{array}{l}31 . \\
\text { Oct. }\end{array}$ & 870 & 53 & 3,880 & $<.010$ & 72.0 & $<10$ & 11,000 & 7 & 40 & 230 \\
\hline $\begin{array}{l}15 \ldots \\
20 \ldots \\
21 \ldots \\
22 \ldots\end{array}$ & $\begin{array}{rr}9 & 960 \\
. & 1,300 \\
. & 1,200 \\
. & 1,400\end{array}$ & $\begin{array}{l}7.9 \\
55 \\
54 \\
54\end{array}$ & $\begin{array}{l}4,630 \\
9,070 \\
8,550 \\
9,440\end{array}$ & $\begin{array}{r}-- \\
.040 \\
.040 \\
.030\end{array}$ & $\begin{array}{l}-- \\
67.0 \\
68.0 \\
67.0\end{array}$ & $\begin{array}{r}<10 \\
10 \\
<10 \\
<10\end{array}$ & $\begin{array}{l}11,000 \\
17,000 \\
16,000 \\
17,000\end{array}$ & $\begin{array}{l}20 \\
20 \\
20 \\
20\end{array}$ & $\begin{array}{l}30 \\
50 \\
40 \\
50\end{array}$ & $\begin{array}{l}320 \\
360 \\
370 \\
360\end{array}$ \\
\hline $\begin{array}{c}\text { Nov. } \\
04 \ldots \\
05 \ldots \\
13 \ldots \\
24 \ldots\end{array}$ & $\begin{array}{l}1,500 \\
.1,500 \\
.1,800 \\
. \quad 2,000\end{array}$ & $\begin{array}{l}52 \\
52 \\
54 \\
51\end{array}$ & $\begin{array}{r}9,940 \\
10,100 \\
10,300 \\
10,700\end{array}$ & $\begin{array}{l}.030 \\
.030 \\
.040 \\
.020\end{array}$ & $\begin{array}{c}88.0 \\
88.0 \\
100 \\
24.0\end{array}$ & $\begin{array}{l}10 \\
10 \\
20 \\
10\end{array}$ & $\begin{array}{l}19,000 \\
19,000 \\
20,000 \\
21,000\end{array}$ & $\begin{array}{l}10 \\
10 \\
20 \\
10\end{array}$ & $\begin{array}{r}50 \\
50 \\
50 \\
9\end{array}$ & $\begin{array}{l}360 \\
360 \\
350 \\
320\end{array}$ \\
\hline $\begin{array}{l}1988 \\
\text { Jan. }\end{array}$ & & & & & & & & & & \\
\hline $\begin{array}{l}24 \\
\text { Feb. }\end{array}$ & 2,200 & 52 & 9,780 & .060 & 20.0 & $<10$ & 17,000 & 10 & 4 & 260 \\
\hline $\begin{array}{l}03 \\
25 \\
\text { Mar. }\end{array}$ & $\begin{array}{rr}2,200 \\
\text {. } \quad 760\end{array}$ & $\begin{array}{l}50 \\
--\end{array}$ & $\begin{array}{r}10,200 \\
8,010\end{array}$ & $\begin{array}{l}.080 \\
.030\end{array}$ & $\begin{array}{l}140 \\
90.0\end{array}$ & $\begin{array}{l}<10 \\
<10\end{array}$ & $\begin{array}{l}17,000 \\
13,000\end{array}$ & $\begin{array}{l}10 \\
10\end{array}$ & $\begin{array}{l}50 \\
60\end{array}$ & $\begin{array}{l}320 \\
280\end{array}$ \\
\hline $\begin{array}{c}25 \\
\text { Apr. }\end{array}$ & . 1,300 & 50 & 8,830 & $<.010$ & 110 & $<10$ & 13,000 & 10 & 40 & 270 \\
\hline $\begin{array}{l}14 . \\
27 . \\
\text { May }\end{array}$ & $\begin{array}{l}\cdots \\
\cdots\end{array}$ & $\overline{48}$ & 6,500 & $<.010$ & $\overline{40.0}$ & $<10$ & 9,100 & $\overline{10}$ & $\overline{30}$ & 250 \\
\hline 11. & $\begin{array}{lr}. & -- \\
. & 460\end{array}$ & $\overline{45}$ & 6,080 & $<.010$ & $\overline{35.0}$ & $<10$ & 8,700 & $\overline{10}$ & 30 & 230 \\
\hline $\begin{array}{l}\text { June } \\
08 \text {. } \\
\text { Sept. }\end{array}$ & -- & -- & -- & - & -- & -- & -- & -- & -- & -- \\
\hline $\begin{array}{l}20 \\
\text { Oct. }\end{array}$ & . . 1,700 & 14 & 11,300 & $<.010$ & 100 & 10 & 22,000 & 20 & 30 & 350 \\
\hline 03. & -- & -- & -- & -- & -- & -- & -- & -- & -- & -- \\
\hline
\end{tabular}


Table 7. Field measurements and chemical analysis of drainwater--Continued

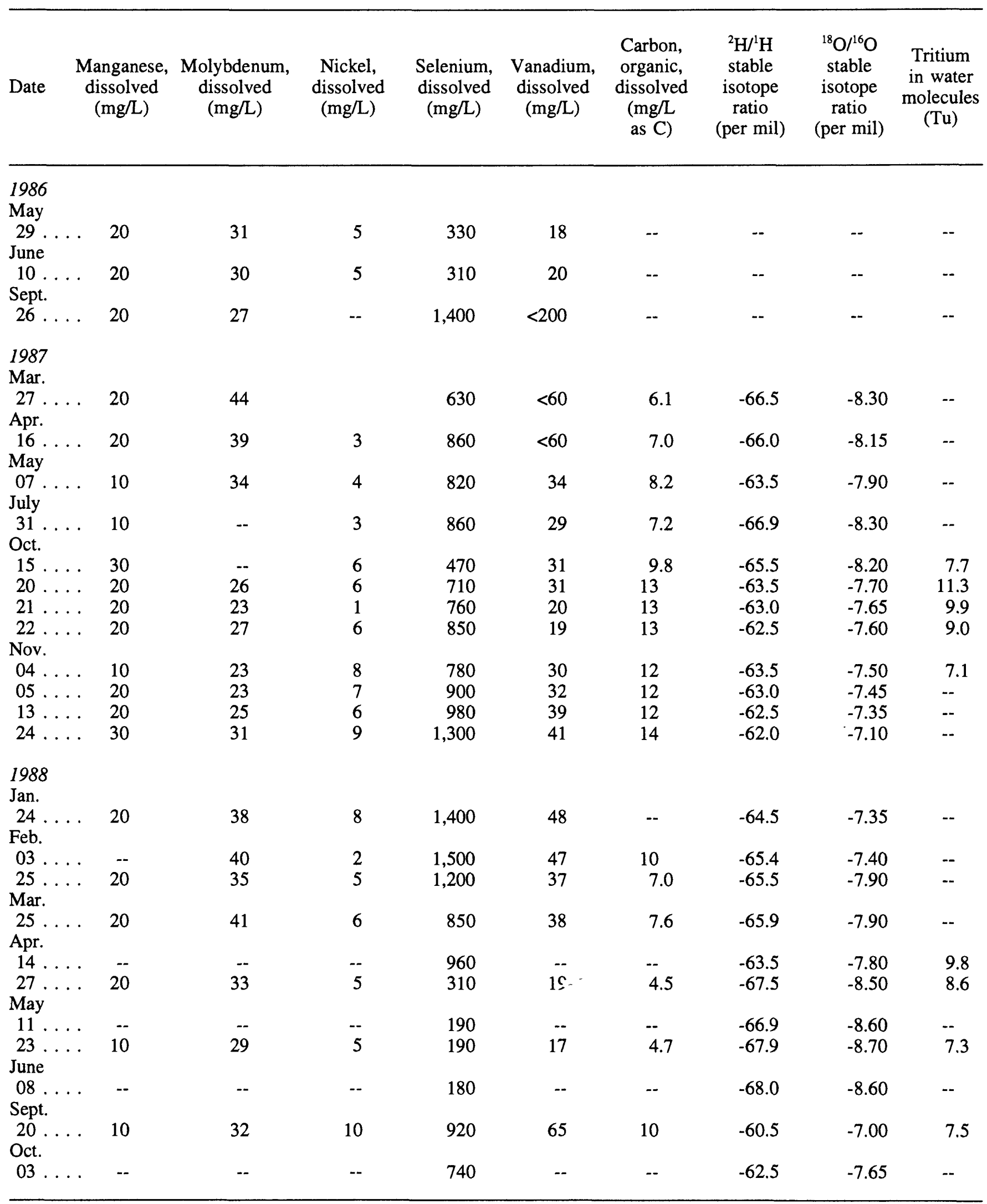

